\title{
Catalytic gasification of humin based by-product from biomass processing - A sustainable route for hydrogen
}
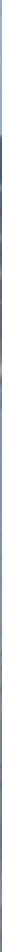
CATALYTIC GASIFICATION OF HUMIN BASED BY-PRODUCT FROM BIOMASS PROCESSING A SUSTAINABLE ROUTE FOR HYDROGEN

\section{Hoàng Thị Minh Châu}

(Thi Minh Chau Hoang in European name format) 


\section{Promotion committee}

$\begin{array}{lll}\text { Prof. dr. ir. J.W.M. Hilgenkamp } & \begin{array}{l}\text { Chairman } \\ \text { Prof. dr. K. Seshan }\end{array} & \begin{array}{l}\text { University of Twente } \\ \text { University of Twente }\end{array} \\ \text { Prof. dr. ir. L. Lefferts } & \text { Promoter } & \text { University of Twente } \\ \text { Prof.dr. J.G.E. Gardeniers } & & \text { University of Twente } \\ \text { Prof. dr G. Mul } & \text { University of Twente } \\ \text { Prof.dr. H.J. Heeres } & \text { University of Groningen } \\ \text { Dr.ir. J.C. van der Waal } & \text { Avantium Technologies B. V. } \\ \text { Prof. V.L.S. Teixeira da Silva } & & \text { Universidade Federal do Rio } \\ & & \text { de Janeiro, Brazil }\end{array}$

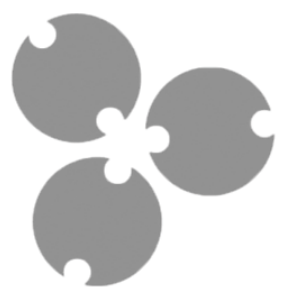

This research was performed within the framework of the CatchBio programme. The author gratefully acknowledge the support of the Smart Mix Program of the Netherlands Ministry of Economic Affairs, Agriculture and Innovation and the Netherlands Ministry of Education, Culture and Science, project number 053.70 .113

Cover design: Hoàng Thị Minh Châu and Bert Geerdink

Motivation: The background of the thesis cover represents Ha Long Bay, a UNESCO World Heritage Site which is located about $170 \mathrm{~km}$ north east from my home city. According to the legend, this archipelago was derived from the jade of Dragons protecting my country against the Northern invader. Two objects in the front represented with humin and steam are the symbol of the site called "the kissing rocks", or "fighting roosters" due to different perspectives. The relationship between humin and steam is similar to the meaning of the symbol. The orange ribbon on the back cover symbolises a kite as well as the shape of my home country - Vietnam. It embodies the connection to my roots and the Netherlands. The small humin aggregates present the Paracel (Hoang Sa) and Spratly (Truong Sa) archipelago which have been governed by Vietnam for hundreds of years according to historical documents. I place them here with the hope for peace to these sea areas.

Publisher: Gilderprint, Enschede, the Netherlands.

This book is printed on total chlorine free paper

Copyright (C) Thi Minh Chau Hoang, 2014. All rights reserved. No part of this document may be reproduced or transmitted in any form or by any means, electronic, mechanical, photocopying, recording or otherwise without prior written permission of the copyright holder

ISBN number: 978-90-365-3706-3. DOI-number: 10.3990/1.9789036537063 


\title{
CATALYTIC GASIFICATION OF HUMIN BASED BY-PRODUCT FROM BIOMASS PROCESSING - A SUSTAINABLE ROUTE FOR HYDROGEN
}

\author{
DISSERTATION \\ to obtain \\ the degree of doctor at the University of Twente, \\ on the authority of the rector magnificus, \\ Prof. dr. H. Brinksma,
} on account of the decision of the graduation committee to be publicly defended on Friday, July $18^{\text {th }}, 2014$ at 16: 45

by

\section{Hoàng Thị Minh Châu}

(Thi Minh Chau Hoang in European name format) born on November $27^{\text {th }}$, in Hanoi, Vietnam 
This dissertation has been approved by the promoters

Prof. dr. K. Seshan

Prof. dr. ir. L. Lefferts 
Dành tặng Mẹ và em gái - Phương (Dedicated to my Mother and my younger sister) 

“Khi ta ở chỉ là nơ đất ở

Khi ta đi đất đã hóa tâm hồn"

(From the poem "Tiếng hát con táu" - Chế Lan Viên)

(Translation: from the poem "The song from a train" by Chế Lan Viên

When staying there, it was just where I lived

When going far away that place became a part of the soul)

"Our greatest weakness lies in giving up. The most certain way to succeed is always to try just one more time" (Thomas Alva Edison) 



\section{Contents}

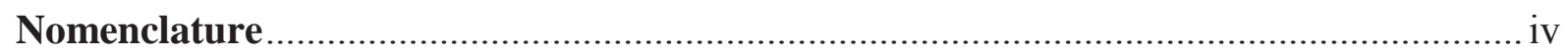

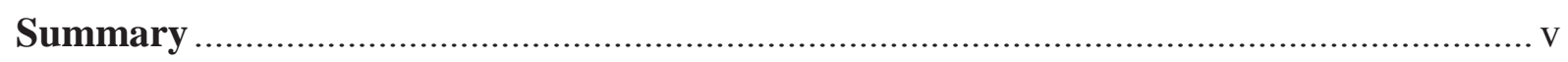

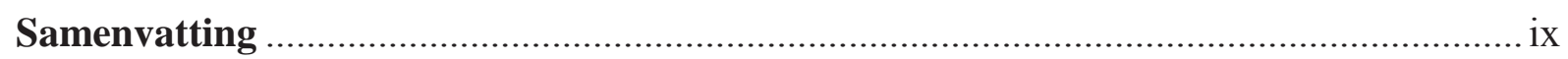

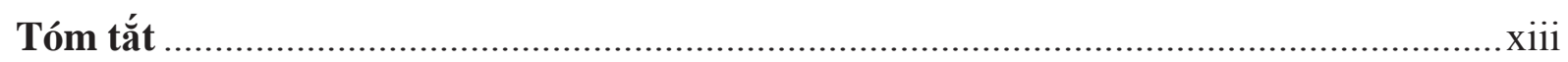

Opportunity from problem: sustainable hydrogen for biorefinery from humin by-

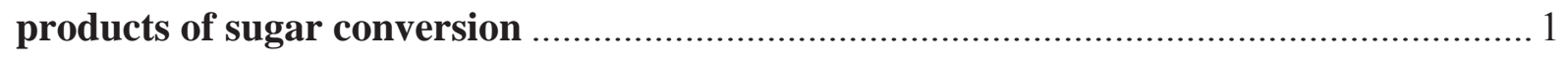

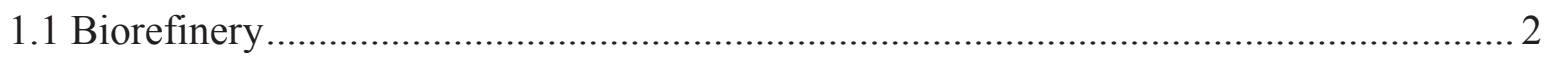

1.2 Top value added bio-platform molecules .............................................................. 4

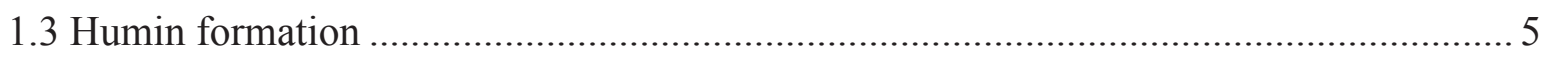

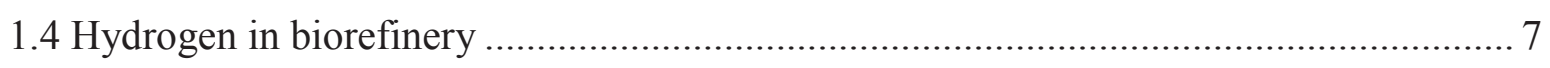

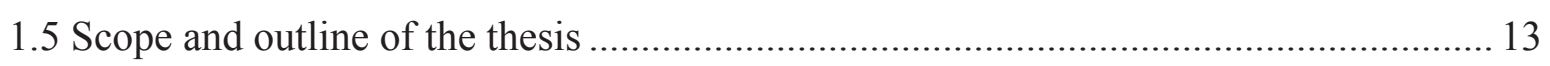

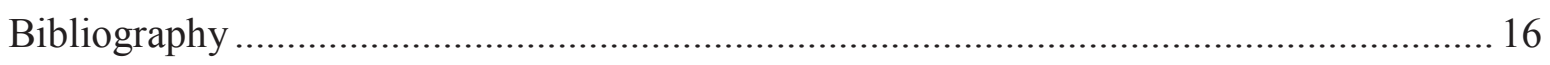

Characterisation of humin - the insight to chemical structure \& Reactivity of humin in

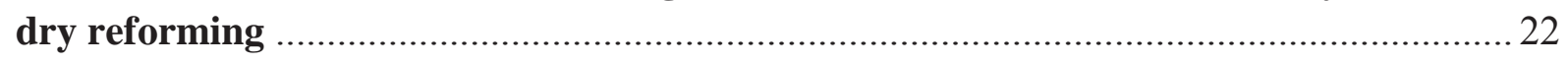

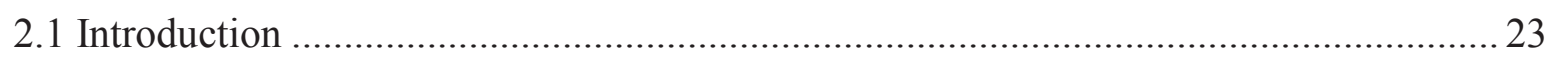

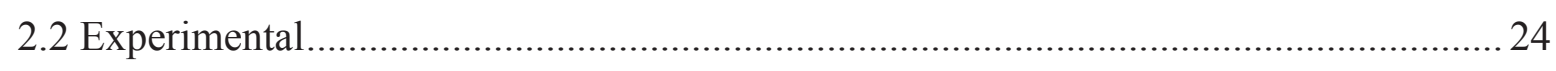

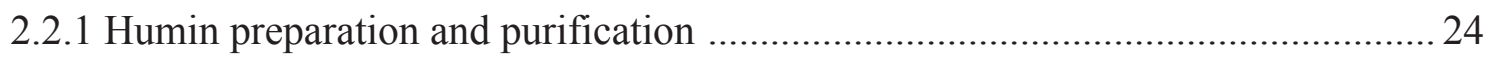

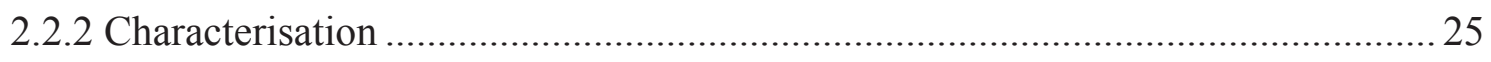

2.2.2 Thermo-gravimetric analysis and dry reforming experiments ..............................26

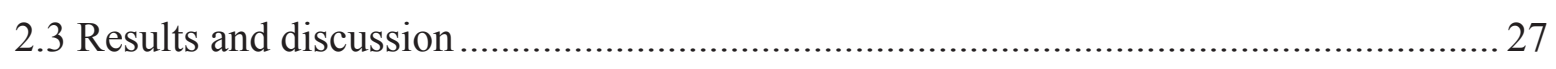

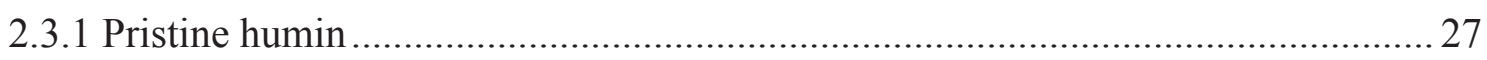

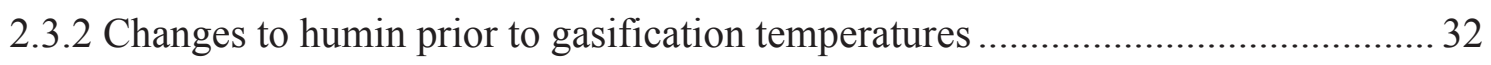

2.3.3 Discussion of the change in structure of humin at elevated temperatures............. 38

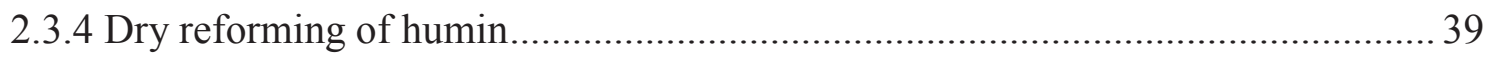

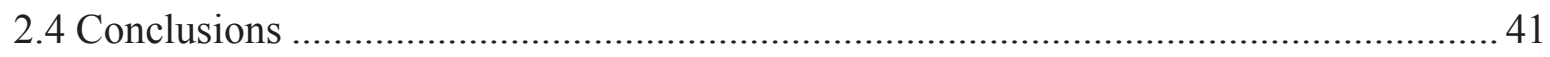

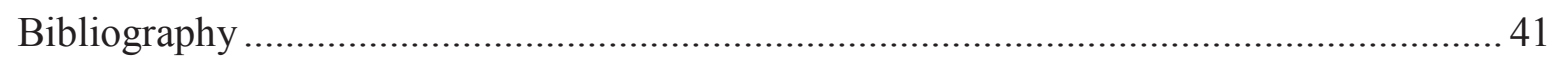

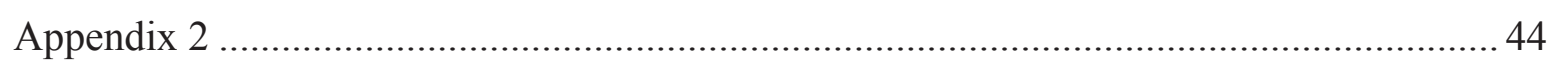


Valorisation of humin-based by-products from biomass processing - A route to

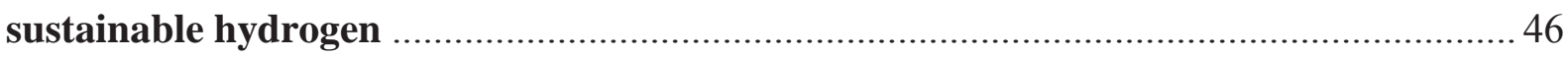

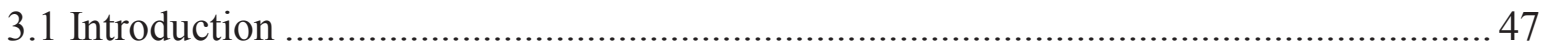

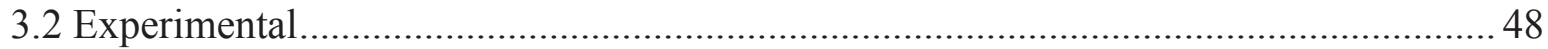

3.2.1 Humin preparation, purification and thermal pre-treatment ............................... 48

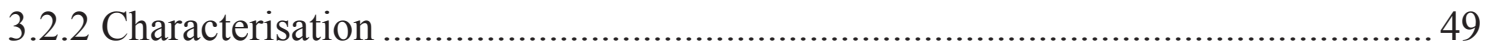

3.2.2 Thermo-gravimetric Analysis (TGA) and gasification experiments .................... 49

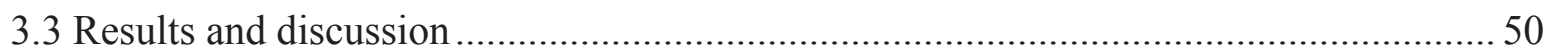

3.3.1 Thermal steam gasification of humin …......................................................... 50

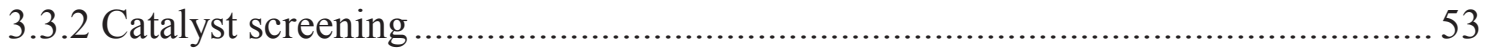

3.3.3 Influence of sodium carbonate on gasification ................................................... 54

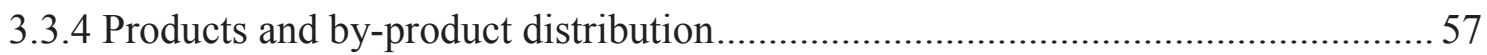

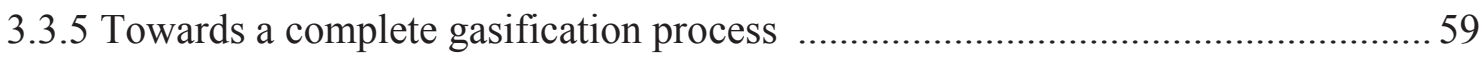

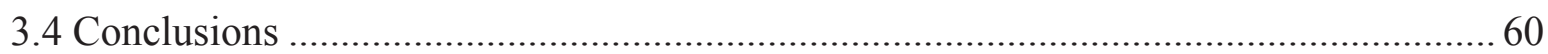

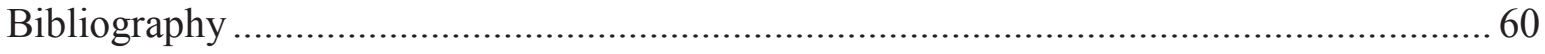

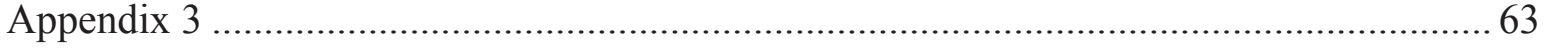

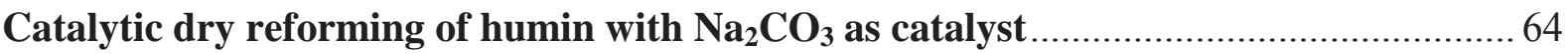

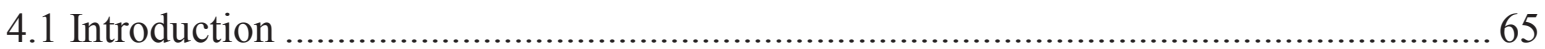

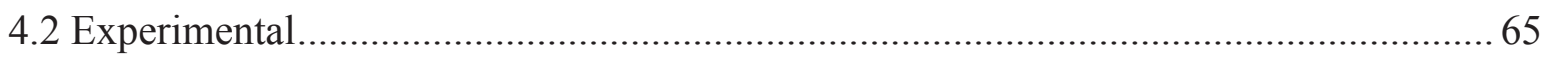

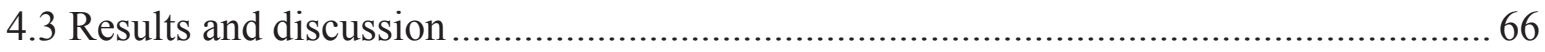

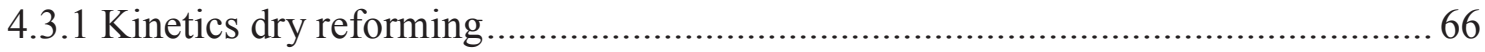

4.3.2 Consideration of reaction pathway in catalytic dry reforming of humin with

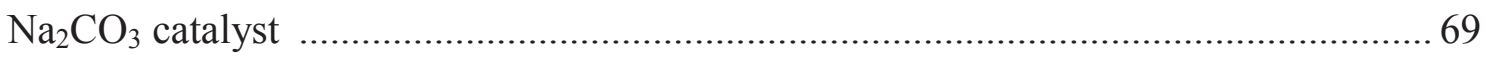

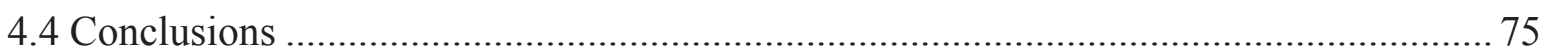

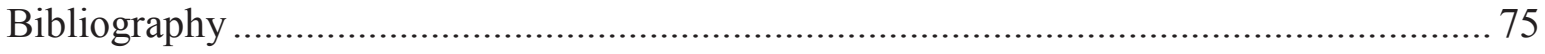

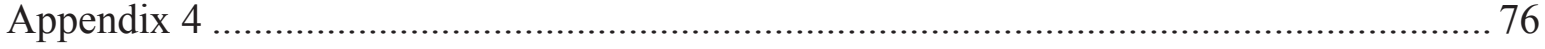

Investigation of $\mathrm{Ce}-\mathrm{Zr}$ oxide supported $\mathrm{Ni}$ catalysts in steam reforming of meta-cresol as

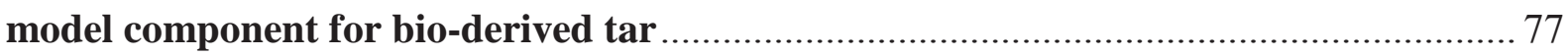

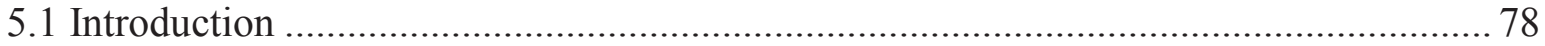

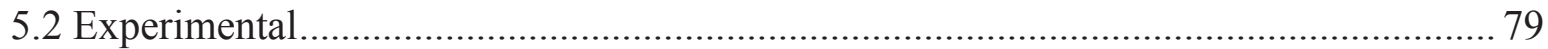

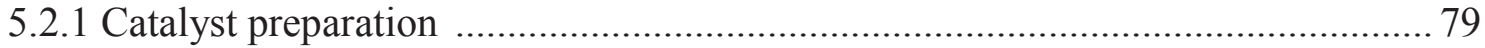

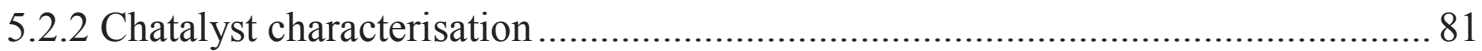




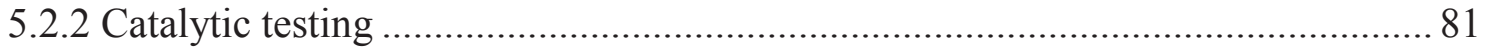

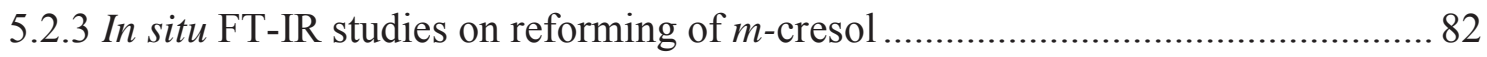

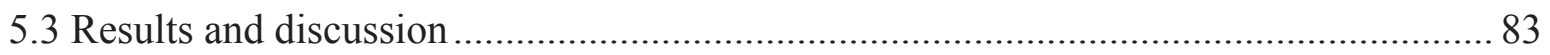

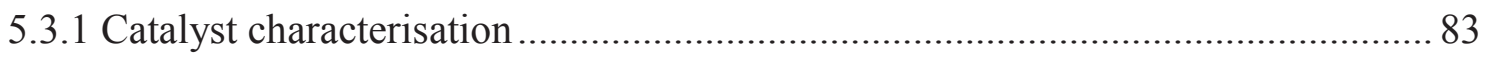

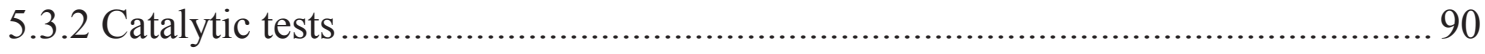

5.3.3 Characterisation of coke deposits on used catalysts ........................................ 92

5.3.4 In situ FT-IR of steam reforming of $m$-cresol on HT and IM based catalysts....... 93

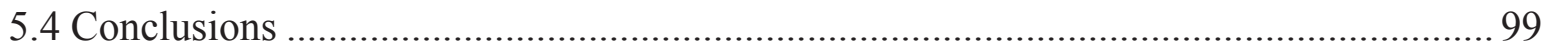

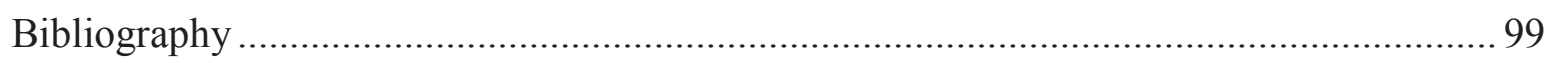

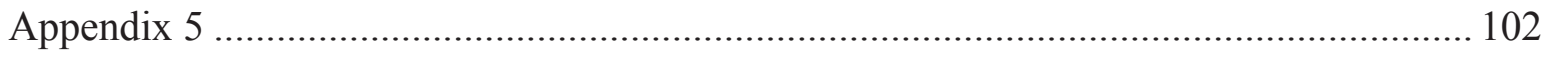

Steam reforming of acetic acid with nickel supported on ceria-zirconia...................... 105

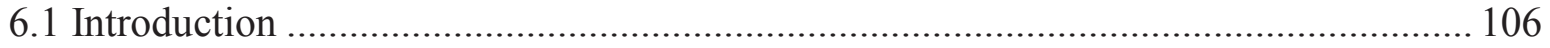

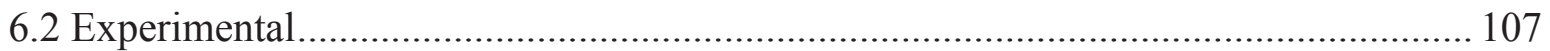

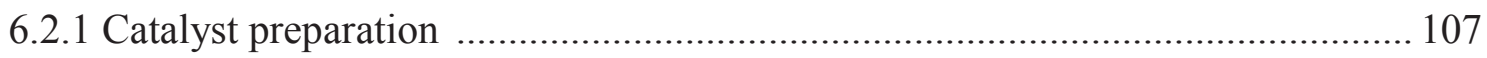

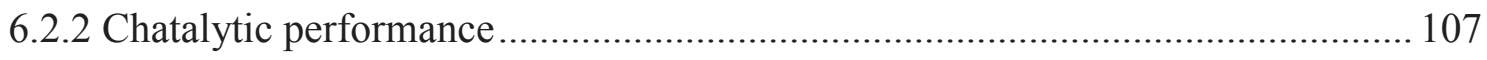

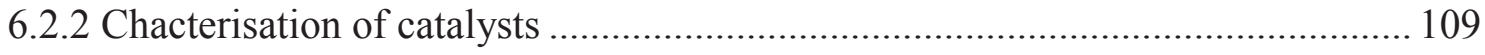

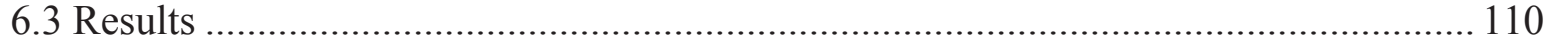

6.3.1 Influence of temperature on catalyst performance ........................................ 110

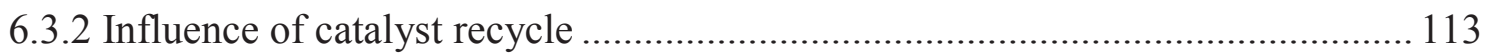

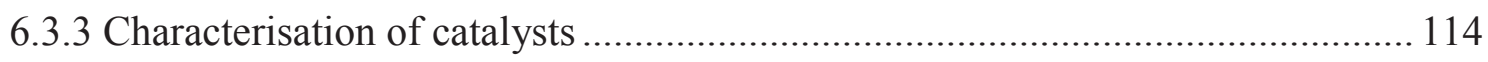

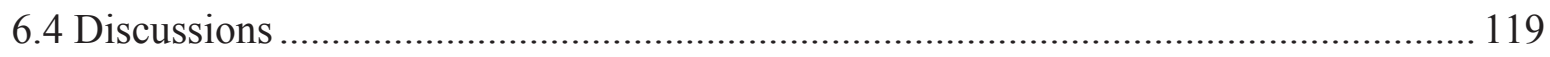

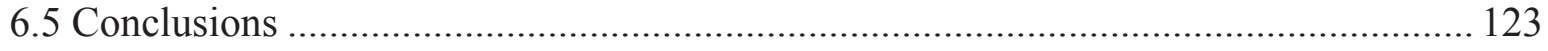

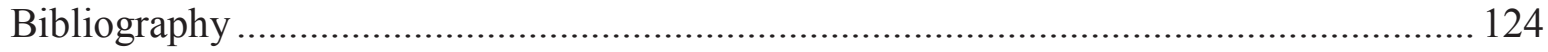

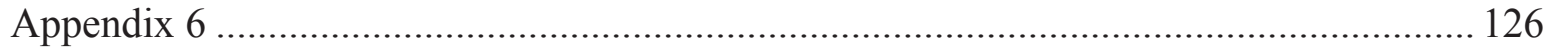

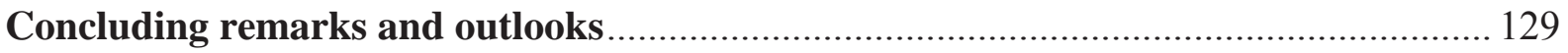

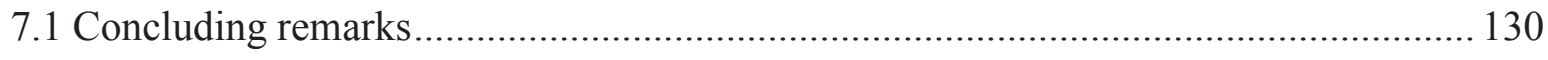

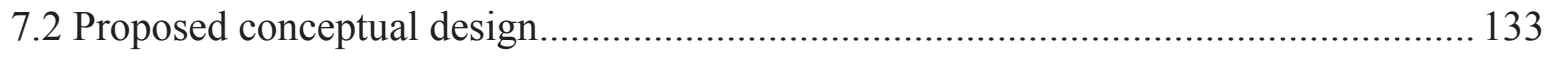

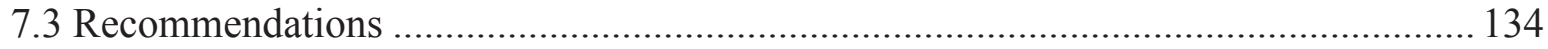

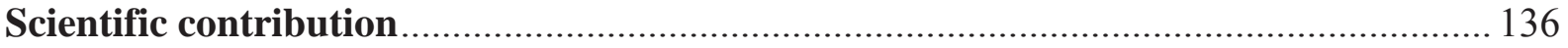

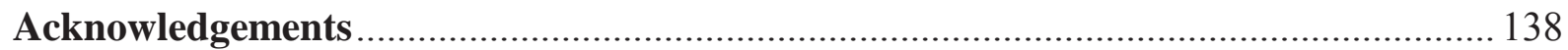




\section{Nomenclature}

\section{Chemicals}

$\begin{array}{llll}\text { AcOH } & \text { Acetic acid } & \text { HG } & \text { Humin } \\ \text { DMSO } & \text { Dimethyl sulfoxide } & \text { HMF } & \text { 5-hydroxy methyl furfural } \\ \text { EtOH } & \text { Ethanol } & \text { IBMK } & \text { Isobutyl methyl ketone } \\ \text { FF } & \text { Furfural } & \text { MeOH } & \text { Methanol } \\ \text { FDCA } & \text { 2,5-Furandicarboxylic acid } & \text { LA } & \text { Levulinic acid } \\ \text { GVL } & \gamma \text {-valerolactone } & \text { THF } & \text { Tetra hydro furan }\end{array}$

\section{Variables}

$\mathrm{S} / \mathrm{C}$

S-(Product A)

$\mathrm{X}$

Y-(Product A)
Steam to carbon ratio

Selectivity to product A

Conversion

Yield of product A

\section{Characterisation techniques and others}

$\begin{array}{ll}\text { ATR-IR } & \text { Attenuated total reflection-infrared spectroscopy } \\ \text { BM } & \text { Ball-milling } \\ \text { CP } & \text { Co-precipitation } \\ \text { ESI } & \text { Electron-spray ionisation } \\ \text { FT-IR } & \text { Fourier transform infrared spectroscopy } \\ \text { GPC } & \text { Gel permeation chromatography } \\ \text { HPLC } & \text { High performance liquid chromatography } \\ \text { HR-SEM } & \text { High resolution-scanning electron microscopy } \\ \text { HT } & \text { Hydrothermal } \\ \text { IM } & \text { Impregnation } \\ \text { LEIS } & \text { Low energy ion scattering } \\ \text { (MA)LDI-TOF } & \text { (Matrix assisted) laser desorption/ionisation-time of flight } \\ \text { MAS-NMR } & \text { Magic angle spinning - nuclear magnetic resonance } \\ \text { MS } & \text { Mass spectroscopy } \\ \text { RT } & \text { Room temperature } \\ \text { TGA } & \text { Thermo gravimetric analysis } \\ \text { TOS } & \text { Time on stream } \\ \text { TPO } & \text { Temperature programmed oxidation } \\ \text { TPR } & \text { Temperature programmed reduction } \\ \text { WGS } & \text { Water gas shift } \\ \text { XPS } & \text { X-ray photoelectron spectroscopy } \\ \text { XRD } & \text { X-ray diffraction } \\ \text { XRF } & \text { X-ray fluorescence }\end{array}$




\section{Summary}

Nowadays, fuels and chemicals are mainly derived from fossil feed stocks (e.g., crude oil, natural gas or coal). However, the combustion of fossil fuels is believed to be responsible for the global warming (i.e., via the emission of greenhouse gases). A lot of interest in finding adequate sustainable alternative resources has been generated due to the decrease of fossil feedstock reservoirs as well as the problem of climate change. Lignocellulosic biomass is addressed as the only carbon containing sustainable alternative resource for our needs towards chemicals and fuels. Thus, biorefinery concepts are proposed as guidelines for making energy, fuels and chemicals from different components of biomass. Synthesis of chemicals/fuels from biomass can be done via various approaches, namely liquefaction (i.e., flash pyrolysis, high pressure liquefaction), gasification followed by Fischer-Tropsch conversion or fractionation of biomass to natural polymers (e.g., cellulose, hemicellulose, lignin) which are subsequently converted to platform chemical molecules.

The conversion of (hemi)celluloses is important in the biorefinery scheme since they comprise 70 - 80 wt.\% of biomass. Furans (HMF, FF, FDCA) and levulinic acid (LA) are in the list of Top Ten value added platform molecules from carbohydrates - which include hemicellulose and cellulose. The conversion of carbohydrate to these molecules requires depolymerisation of polysaccharides to sugar monomers and dehydration of the corresponding sugar to HMF, FF or LA. One of the major problems in such conversion is the formation of large amounts of solid by-products, namely humin.

A lot of efforts have been made to suppress humin formation in the sugar conversion processes. However, it involves the use of expensive solvents (e.g., ionic liquids), and the related difficulty and high energy input required for product separation. In the meantime, however, in order to achieve a breakthrough in the conversion technology, valorisation of the humin by-product should be taken into account to improve the economic value and environmental factor of the whole bio-process. On the other hand, upgrading of these biofuels and bio derived platform chemicals demands large amounts of hydrogen which should also be produced from sustainable resources (e.g., water or biomass). Therefore, the approach for producing hydrogen from humin is conceptually attractive. This can provide green hydrogen for downstream processing in biorefinery.

Although the presence of humin was reported in almost every single literature on HMF, LA synthesis, its chemical structure, properties or useful conversion is not well understood. 
vi Summary

The objective of this research is investigating the potential of humin for gasification to produce sustainable hydrogen/synthesis gas.

In the first part of this thesis, the fundamental study on the chemical structure of humin as well as its characteristics during the gasification is elucidated. The pristine humin, derived from D-glucose, can embed considerable amounts of extractable components ( 8 - 16 wt.\%) which are (by)products derived from the dehydration of sugars (e.g., HMF, LA, soluble humin). Results of spectroscopy analysis (ATR-IR, ${ }^{13} \mathrm{C}$ solid state MAS NMR) as well as the pyrolysis data helped to understand the structure of humin. The humin framework consists of furanic segments with aliphatic linkages decorated by carboxylic and ketone groups. Mass spectrometry (ESI-MS, GPC, LDI-TOF) indicated the abundant presence of the mass 301 Dalton. By combining these data, a chemical structure of humin segments, and humin was proposed.

In the first stage of the gasification (in steam and/or $\mathrm{CO}_{2}$ ), i.e. pyrolysis or devolatilisation stage, humin undergoes drastic changes in morphology, composition and chemical structure. During this stage, humin turns from a dense to a porous structure due to the decomposition of functional groups and escape of the volatiles. In $\mathrm{CO}_{2}$ reforming, hollow spherical particles were formed which implied the asymmetric composition of humin. The most important knowledge obtained about this stage in gasification, is that humin becomes more and more aromatised/graphitised, resulting in very high carbon content (above $90 \mathrm{wt} . \%$ ) and it lost about $25 \mathrm{~mol}$ \% carbon into vapour phase in the form of gas $\left(\mathrm{CO}, \mathrm{CO}_{2}\right)$ and organic volatiles (e.g., phenols, acetic acid, poly-aromatics). In some cases, traces of $\mathrm{S}$ containing species such as DMSO-2 was present in the volatile stream (S containing species released at temperature below $400{ }^{\circ} \mathrm{C}$ ). Humin residue showed very low reactivity towards steam $/ \mathrm{CO}_{2}$ reforming, thus thermal gasification of humin requires elevated temperature (above $1050{ }^{\circ} \mathrm{C}$ ). Therefore, it is essential to employ catalysts to improve the reaction rate, reduce the gasification temperature and thus the energy input to the process.

Alkali metal carbonates are active for gasification. Sodium carbonate showed the highest activity for gasification of humin and it was selected for further investigation. The activation energy for dry reforming in the presence of sodium carbonate is in the same range as that for bio-char gasification. The kinetics study on steam and dry reforming of humin revealed that the conversion rate was quite stable over a wide range of conversions (conversion is proportional to TOS) and the catalytic reforming resembled the bulk reaction. Complete conversion was achieved for steam reforming in the presence of $\mathrm{Na}_{2} \mathrm{CO}_{3}$ (selectivity to $\mathrm{CO}$ and $\mathrm{CO}_{2}$ is 75 and $25 \%$, respectively; $\mathrm{H}_{2} / \mathrm{CO} \sim 2$ ), however, loss of catalyst into gas phase was observed and explained by the transformation of $\mathrm{Na}_{2} \mathrm{CO}_{3}$ to 
mobile/volatile species (e.g., $\mathrm{Na}, \mathrm{Na}_{2} \mathrm{O}_{2}$ ). Adding $\mathrm{CO}_{2}$ to the feed stream for steam reforming increased the stability of $\mathrm{Na}_{2} \mathrm{CO}_{3}$ tremendously. Therefore, in the conceptual design, combining $\mathrm{CO}_{2}$ and steam for the catalytic gasification is essential. The $\mathrm{H}_{2}$ yield can be further increased by implementating WGS step after gasification. Further investigation of the nature of sodium species which might contribute to the catalytic activity was studied using dry reforming with isotopic $\mathrm{Na}_{2}{ }^{13} \mathrm{CO}_{3}$ and ${ }^{23} \mathrm{Na}$ MAS-NMR. The results from these techniques revealed that $\mathrm{Na}_{2} \mathrm{CO}_{3}$ is in the mixed oxide/carbonate form at the gasification temperatures.

To maximise the use of carbon in humin as well as to clean up the gas stream, removal of the volatile tars via steam reforming is required. The second part of the thesis (Chapter 5 and 6) focuses on the development of $\mathrm{Ni}$ based catalyst for steam reforming of the tar products. Non-noble catalyst systems consisting of supported $\mathrm{Ni}$ on ceria-zirconia solid solutions were developed with a preference to the influence of supports synthesis to the catalytic performance. The use of $m$-cresol and acetic acid as model components for the volatiles of humin covers most of chemical functionalities for the vapour mixture. Ceriazirconia mixed oxide has good redox properties which can contribute to the oxidation of coke deposits on catalyst thus preventing catalyst deactivation. Three ceria-zirconia mixed oxides synthesised via co-precipitation, co-precipitation followed by hydrothermal treatment, impregnation were developed and characterised. Ni supported on ceria-zirconia synthesised via co-precipitation followed by hydrothermal treatment showed the most promising for $\mathrm{m}$ cresol reforming Results from characterisation of fresh and used catalyst as well as the FT-IR study on the steam reforming of $\mathrm{m}$-cresol helped to explain the performance of the catalysts.

For steam reforming of $m$-cresol, the supported $\mathrm{Ni}$ was attributed to influence the main activity for $\mathrm{C}-\mathrm{C}$ and $\mathrm{C}-\mathrm{H}$ cleavage (of $m$-cresol). The in situ FT-IR study revealed the horizontal adsorption of the aromatic rings on the Ni surface and the interaction of methyl group with the support. This allowed multiple cleavages to occur at the same time on the catalyst. Since manifold sites including Ni involved in the reforming of m-cresol, relatively large Ni crystallites (within optimum range) might be more favoured.

Since acetic acid is the most abundant aliphatic component in the volatile tar stream from humin, performance of the optimal catalyst in acetic acid steam reforming is of interest. Due to its notoriousness for causing catalyst deactivation, the steam reforming of acetic acid was studied with preference to the stability of the catalyst. Improvement in activity of the recycled catalysts was observed and discussed based on the characterisation results (LEIS, Raman spectroscopy, TPO/TPR). Modification of $\mathrm{Ce}$ - or $\mathrm{Zr}$ - O bonds happened under the redox treatment or steam reforming conditions, especially in the latter case. The result also 
indicated that the gained active sites located in the proximity of $\mathrm{Ni}$ particles where the deprotonated acetic acid was adsorbed and converted via dehydration pathway. Oxygen mobility of the support was the key factor for preventing coke deposits on the catalyst, thus improving the catalyst activity and stability

To conclude, the whole process of humin gasification was studied. Humin is a potential carbonaceous material for producing sustainable hydrogen. The thesis covers fundamental investigation on chemical structure of humin byproduct from de-hydration of D-glucose for making levulinic acid (a bio chemical building block) as well as the entire gasification of humin (devolatilisation, gasification, steam reforming of tar). The findings in this thesis can also contribute to gasification of a wider bio-derived feedstock range (e.g., lignocellulose, bio-oils). 


\section{Samenvatting}

Brandstoffen en chemicaliën worden tegenwoordig voornamelijk geproduceerd uit fossiele grondstoffen (zoals aardolie, aardgas en kolen). De verbranding van deze fossiele brandstoffen wordt echter gezien als oorzaak voor de opwarming van de aarde (via de emissie van broeikasgassen). Er is veel interesse voor het vinden van geschikte alternatieve bronnen, zowel vanwege het opraken van fossiele bronnen als vanwege het probleem van klimaatverandering. Lignocellulose biomassa wordt gezien als de enige koolstofhoudende duurzame alternatieve bron voor chemicaliën en brandstoffen. Concepten voor bioraffinage zijn voorgesteld als richtlijnen voor het maken van energie, brandstof en chemicaliën uit verschillende componenten van biomassa. De productie van chemicaliën/brandstoffen uit biomassa kan gedaan worden op verschillende manieren, namelijk liquefactie (bijvoorbeeld snelle pyrolyse, hogedrukliquefactie), vergassing gevolgd door Fischer-Tropschconversie of fractionatie van biomassa naar natuurlijke polymeren (bijvoorbeeld cellulose, hemicellulose, lignin) die vervolgens naar bulkchemicaliën worden omgezet.

De conversie van (hemi)cellulosen is belangrijk in het bioraffinaderijconcept, omdat zij 70 - 80 gew.\% van biomassa uitmaken. Furanen (HMF, FF, FDCA) en levulinezuur (LA) staan in de top 10 van waardevolle bulkchemicaliën uit koolwaterstoffen zoals hemicellulose en cellulose. De omzetting van koolwaterstoffen naar deze moleculen vereist depolymerisatie van polysachariden naar suikermonomeren en dehydrogenatie van desbetreffende suikers naar HMF, FF of LA. Een van de voornaamste problemen in dergelijke conversies is het ontstaan van grote hoeveelheden vast bijproduct, humin genaamd.

Er is veel aandacht besteed aan het onderdrukken van de vorming van humin bij het omzetten van suiker. Dit vereist echter het gebruik van kostbare solvent (zoals ionogene vloeistoffen), met de daarmee gepaard gaande hoge complexiteit en hoge energie-input voor scheiding van de producten. Terwijl het onderzoek naar betere conversiemethoden doorgaat, dient om een doorbraak in de conversietechnologie te forceren tegelijkertijd te worden gekeken naar het valorizeren van de humin bijproducten, om zodoende de economische en ecologische factoren van het gehele bioproces te verbeteren. Aan de andere kant kost het opwaarderen van deze bio-brandstoffen en de uit biomassa afkomstige basis chemicaliën grote hoeveelheden waterstof, die ook moet komen uit duurzame bronnen (zoals waterkracht of biomassa). Daarom is het produceren van waterstof uit humin een aantrekkelijk concept. 
Hiermee kan 'groen' waterstof worden geproduceerd voor de downstream processen in de bioraffinaderij.

Hoewel de aanwezigheid van humin wordt vermeld in bijna elke studie over synthese van HMF en LA, worden de chemische structuur, eigenschappen en nuttige verwerking ervan niet goed begrepen. Het doel van dit onderzoek is inzicht te krijgen in de mogelijkheden om humin te gebruiken voor de productie van duurzaam waterstof/synthesegas te produceren door middel van vergassing.

Het eerste deel van deze thesis bestaat uit een fundamentele studie naar de chemische structuur van human en de eigenschappen tijdens de vergassing. De onbewerkte humin, afkomstig van G-glucose, kan aanzienlijke hoeveelheden winbare bestanddelen bevatten ( 8 16 wt.\%) die (bij)producten zijn van de dehydrogenatie van suikers (zoals HMF, LA en oplosbare humin). De resultaten van de spectroscopie-analyse (ATR-IR, ${ }^{13} \mathrm{C}$ vastestof MAS NMR) evenals de pyrolysedata helpen inzicht te verkrijgen in de structuur van humin. Het humin-geraamte bestaat uit delen van furanen met alifatische verbindingen aangevuld met carboxylische groepen en ketongroepen. Massaspecrometrie (ESI-MS, GPC, LDI-TOF) liet zien dat de massa van 301 Dalton in hoge mate aanwezig is. Door deze informatie te combineren is een vermeede chemische structuur van humin segmenten voorgesteld, en een mogelijke structuur van humin.

In de eerste fase van de vergassing (in stoom en/of $\mathrm{CO}_{2}$ ), oftewel de pyrolysefase, ondergaat humin drastische veranderingen in morfologie, samenstelling en chemische structuur. Tijdens deze fase verandert humin van een dichte in een poreuze structuur doordat functionele groepen uiteenvallen en vluchtige componenten ontsnappen. Zelfs in $\mathrm{CO}_{2}$ reforming werden holle bolvormige deeltjes gevormd, wat suggereert dat humin een asymetrische samenstelling heeft. Het belangrijkste wat over deze fase is ontdekt, is dat humin meer en meer gearomatiseerd/gegrafitiseerd raakt met als gevolg een zeer hoog koolstofgehalte (boven 90 gew.\%) met een verlies van ongeveer 25 mol.\% koolstof naar de gasfase in de vorm van gas $\left(\mathrm{CO}, \mathrm{CO}_{2}\right)$ en organische vluchtige stoffen fenolen, azijnzuur en poly-aromaten. In sommige gevallen waren sporen van zwavelhoudende stoffen zoals DMSO2 aanwezig in de vluchtige stroom (zwavelhoudende stoffen vrijgelaten bij een temperatuur onder de $400{ }^{\circ} \mathrm{C}$ ). Humin-residu vertoont zeer lage activiteit voor stoom $/ \mathrm{CO}_{2}$ reforming, dus thermische vergassing van humin vereist een zeer hoge temperatuur (boven de $1050{ }^{\circ} \mathrm{C}$ ). Het is daarom essentieel om een katalysator in te zetten om de reactiesnelheid te verhogen en de temperatuur (energie-input) van het vergassingprocess te verlagen. 
Alkalimetaalcarbonaten zijn actief voor vergassing. Natriumcarbonaat vertoonde de hoogste activiteit en is geselecteerd voor verder onderzoek. De activatie-energie voor droge reforming in aanwezigheid van natriumcarbonaat is vergelijkbaar met bio-houtskool vergassing. De kinetiekstudie naar stoom- en droge reforming van humin laat zien dat de conversiesnelheid vrij stabiel is over een groot bereik van de conversie (conversie is evenredig met de TOS) en de katalytische reforming lijkt op de bulkreactie. Volledige conversie kan voor stoomreforming worden bereikt in aanwezigheid van $\mathrm{Na}_{2} \mathrm{CO}_{3}$ (selectiviteit van $\mathrm{CO}$ en $\mathrm{CO}_{2}$ is 75 en $25 \%$, repectievelijk; $\mathrm{H}_{2} / \mathrm{CO} \sim 2$ ), echter, verlies van katalysator naar de gasfase werd waargenomen en verklaard met de transformatie van $\mathrm{Na}_{2} \mathrm{CO}_{3}$ naar beweeglijke componenten (zoals $\mathrm{Na}, \mathrm{Na}_{2} \mathrm{O}_{2}$ ). Het toevoegen van $\mathrm{CO}_{2}$ aan de voedingsstroom voor stoomreformatie verhoogt de stabiliteit van $\mathrm{Na}_{2} \mathrm{CO}_{3}$ aanzienlijk. Daarom is het voor het concentuele ontwerp essentieel dat $\mathrm{CO}_{2}$ - en stoomreforming worden gecombineerd. $\mathrm{Om} \mathrm{de} \mathrm{H}_{2}$ opbrengst te verhogen moet tevens WGS worden geïmplementeerd als stap na de vergassing. Nader onderzoek naar de aard van de natriumverbindingen die mogelijk bijdragen aan de katalytische activiteit is gedaan door middel van droge reforming met gelabelde $\mathrm{Na}_{2}{ }^{13} \mathrm{CO}_{3}$ en ${ }^{23} \mathrm{Na}$ MAS-NMR. De data die hiermee is verkregen toont aan dat $\mathrm{NaCO}_{3}$ zich in oxide/carbonaatvorm bevindt bij de vergassing-temperatuur.

Om het gebruik van humin als bron van koolstof te optimaliseren en de gasstroom te reinigen, is het verwijderen van teer door middel van stoomreforming een vereiste. Het tweede gedeelte van de thesis (Hoofdstukken 5 en 6) concentreren zich op de ontwikkeling van een katalysator op Nikkel-basis voor stoomreforming van de teerproducten. Niet-edele katalysatoren bestaande uit $\mathrm{Ni}$ met een ceria-zirconia mengsel als drager zijn vervaardigd waarbij met name de invloed van de drager-synthese op de katalytische activiteit is getest. Het gebruik van m-cresol en azijnzuur als modelcomponenten voor de vluchtige componenten van humin benadert de chemische functionaliteit van het dampmengsel. Een ceria-zirconia oxide mengsel heeft goede redox-eigenschappen die kunnen bijdragen aan het oxideren van cokesafzetting op de katalysator en deactivatie van de katalysator voorkomen. Drie ceriazirconia oxide mengsels, vervaardigd via coprecipitatie, coprecipitatie gevolgd door hydrothermische behandeling en co-impregnatie zijn gekarakteriseerd. Ni op een drager van ceria-zirconia vervaardigd via coprecipitatie gevolgd door hydrothermische behandeling toont zich het beste voor m-cresol reforming. De resultaten van de karakterisatie van ongebruikte en gebruikte katalysator en de FT-IR studie voor de stoomreforming van m-cresol helpen de prestaties van de katalysator te verklaren.

Voor stoomreforming van m-cresol wordt de Ni met drager verondersteld het breken van C-C en C-H bindingen (van m-cresol) te beïnvloeden. In situ FT-IR toonde de horizontale 
adsorptie van de acomatische ringen on het $\mathrm{Ni}$-oppervlak en de interactie van de methylgroep met de drager. Dit maakt het mogelijk dat meerdere bindingen tegelijkertijd openbreken op de katalysator. Aangezien meerdere sites, inclusief Ni, actief zijn in de reforming van m-cresol, zijn relatief grote Ni-kristallieten (binnen het optimale gebied) gunsiger.

Aangezien azijnzuur de meest aanwezige alifatische component is in de vluchtige teerstroom uit humin, is de activiteit van de optimale katalysator in de stoomreforming van azijnzuur interessant. Vanwege de bekende deactivatie van de katalysator richt de studie naar stoomreforming van azijnzuur zich met name name op de stabiliteit van de katalysator. Een verbetering in activiteit van herbruikte katalysator werd waargenomen, en besproken aan de hand van de characterisatie (LEIS, Raman spectroscopy, TPO/TPR). Aanpassing van Ce- of $\mathrm{Zr}-\mathrm{O}$ bindingen gebeurde tijdens de redoxbehandeling of vergassingcondities, met name tijdens de laatste - stoomreforming van azijnzuur. Het resultaat toont aan ook dat de actieve sites ontstaan in de buurt van Ni-deeltjes waar de gedeprotoneerde azijnzuur adsorbeerd en via dehydrogenatie wordt omgezet. De beweeglijkheid van zuurstof op de drager is de sleutel voor het voorkomen van cokesafzetting op de katalysator, en verhoogd dus de activiteit

Tenslotte is het gehele proces van huminvergassing bestudeerd. Humin is een potentiëel koolstofhoudend materiaal voor het produceren van duurzame waterstof. De thesis omvat fundamenteel onderzoek naar de chemische structuur van humin-bijproduct uit dehydrogenatie van D-glucose voor de productie van levulinezuur, een bio "Lego-steen", alsmede de gehele vergassing van humin (devolatilisatie, vergassing, stoomreforming van teer). De bevindingen in deze thesis kunnen ook bijdragen aan vergassing van een bredere reeks aan biogrondstoffen (waaronder lignocellulose, bio-oliën). 


\section{Tóm tắt}

Ngày nay, nhiên liệu và hóa chất được tổng hợp chủ yếu từ nguyên liệu hóa thạch (ví dụ, dầu thô, khí thiên nhiên hoặc than đá). Tuy nhiên, việc đốt nhiên liệu hóa thạch được cho là tác nhân chủ yếu cho hiện tượng trái đất nóng lên (do việc phát thải khí nhà kính). Ngoài ra, sự cạn kiệt nguồn nhiên liệu hóa thạch đã thúc đẩy các nghiên cứu về các nguồn nguyên liệu bền vững thay thế. Sinh khối thực vật được cho là nguồn nguyên liệu bền vững duy nhất có chứa cacbon để tổng hợp hóa chất và nhiên liệu cho nhu cầu của con người. Do vậy mà khái niệm tinh chế sinh khối thực vật đã được đề xuất và đóng vai trò như cẩm nang hướng dẫn sản xuất nhiên liệu và hóa chất từ các thành phần của sinh khối. Việc sản xuất hóa chất/nhiên liệu từ sinh khối có thể được thực hiện theo nhiều cách khác nhau: hóa lỏng sinh khối (bao gồm nhiệt hóa siêu nhanh, hóa lỏng ở áp suất cao), khí hóa kèm theo quá trình chuyển hóa Fishcher-Tropsch, hoặc phân tách sinh khối thành các polyme thiên nhiên (ví dụ: xenlulo, hemi xenlulo, lignin) từ đó chúng được chuyển hóa thành các chất tổng hợp căn bản cho sản xuất hóa học từ vật liệu tự nhiên.

Sự chuyển hóa (hemi)xenlulo đóng vai trò rất quan trọng trong sơ đồ chung của tinh chế sinh khối thực vật vì chúng là thành phần chủ yếu của sinh khối thực vật (chiếm đến $70-80$ \% khối lượng khô của thực vật). Các hợp chất furan (ví dụ hydroxy methyl furan - HMF, furfural - FF, furan di-carboxylic axit) và levulinic axit (LA) nằm trong Tốp10 chất tổng hợp căn bản từ cacbohyđrat mà bao gồm cả xenlulo và hemi xenlulo. Sự chuyển hóa cacbohyđrat thành các hợp chất tổng hợp căn bản nêu trên yêu cầu việc chia nhỏ các polysaccarit thành đường đơn và loại nước từ phân tử đường đơn này thành HMF, FF hay LA. Một trong những nhược điểm chủ yếu trong quá trính biến đổi như trên là sự phát sinh một lượng lớn sản phẩm phụ dạng rắn, thường được gọi là humin.

Nhiều nghiên cứu đã và đang được thực hiện nhằm khống chế quá trình hình thành humin trong quá trình chuyển hóa đường. Tuy nhiên, việc này đòi hỏi việc sử dụng các loại dung môi đắt tiền (ví dụ chất lỏng ion) và kèm theo đó là việc phân tách sản phẩm phức tạp, tiêu hao nhiều năng lượng. Cho đến khi công nghệ chuyển hóa đường đạt tới thành tựu mong muốn, chúng ta cần xem xét đến khả năng sử dụng của humin từ đó nâng cao giá trị kinh tế và yếu tố môi trường của toàn bộ quá trình chuyển hóa sinh khối. Mặt khác, việc xử lý và chuyển hóa dầu từ sinh khối thực vật hay các chất tổng hợp căn bản từ sinh khối đòi hỏi việc sử dụng một lượng lớn khí $\mathrm{H}_{2}$. Do yêu cầu về sản phẩm xanh/phát triển bền vững nên khí $\mathrm{H}_{2}$ sử dụng cho các quá trình trên cũng phải được tổng hợp từ các nguồn nguyên liệu tái tạo (ví dụ như 
xiv Tóm tắt

nước hay sinh khối). Do vậy việc sử dụng humin cho quá trình sản xuất khí $\mathrm{H}_{2}$ được xem như một giải pháp hợp lý cho việc nâng cao giá trị sử dụng của humin. Bằng cách này, khí $\mathrm{H}_{2}$ "xanh" có thể được tổng hợp và sử dụng trong các quá trình tinh luyện trong sơ đồ biến đổi sinh khối.

Mặc dù hầu hết các nghiên cứu về tổng hợp HMF, LA đều nhắc đến sự xuất hiện của humin, nhưng bản chất hóa học, tính chất hay các quá trình phản ứng của nó không được tìm hiểu chi tiết. Mục đích của đề tài này là nghiên cứu khả năng sử dụng humin cho quá trính khí hóa để sản xuất khí $\mathrm{H}_{2}$ hoặc khí tổng hợp mang tính phát triển bền vững.

Trong phần đầu của luận văn này, nghiên cứu cơ bản về thành phần, cấu trúc hóa học của humin cũng như tính chất của nó trong quá trình khí hóa được thực hiện một cách chi tiết. Humin thô từ quá trình tách nước của $\mathrm{D}$-glucose có thể chứa một lượng lớn tạp chất có thể tách được ( 8 - $16 \%$ khối lượng). Các tạp chất này chủ yếu được hình thành trong quá trình tách nước của đường (ví dụ như HMF, LA, humin tan trong nước). Các kết quả từ phân tích phổ hồng ngoại, ${ }^{13} \mathrm{C}$ cộng hưởng từ cũng như sản phẩm từ quá trình nhiệt hóa humin đem lại những hiểu biết về cấu trúc hóa học của humin,cho thấy nó bao gồm các nhóm furan được liên kết với nhau bởi các mạch hydrocacbon có đính kèm các nhóm keton và cacboxylic. Kết quả từ các phương pháp phân tích khối lượng phân tử (ESI-MS, LDI-TOF, GPC) chỉ ra sự tồn tại phổ biến của khối lượng 301 Dalton. Bằng việc kết hợp các kết quả trên, cấu trúc hóa học của một đoạn thành phần cũng như cấu trúc humin được đề xuất.

Trong giai đoạn đầu của quá trình khí hóa (sử dụng hơi nước hoặc $\mathrm{CO}_{2}$ ) - giai đoạn nhiệt hóa hay phân hủy tách khí, humin biến đổi đáng kể về mặt hình thái, thành phần và cấu trúc hóa học. Trong giai đoạn này, humin chuyển từ cấu trúc đặc sang cấu trúc xốp rỗng do sự phân hủy của các nhóm chức và sự giải phóng các chất hóa hơi. Trong quá trình khí hóa với $\mathrm{CO}_{2}$, các hạt cầu với lõi rỗng được hình thành từ humin ở nhiệt độ cao. Điều này chứng tỏ cấu trúc không đồng nhất của humin theo dọc mặt cắt của nó. Kết luận căn bản nhất về giai đoạn đầu của quá trình khí hóa là humin bị than hóa theo nhiệt độ. Ở nhiệt độ mà quá trình khí hóa thực sự bắt đầu, hơn $90 \%$ khối lượng humin là cacbon và khoảng $25 \%$ mol cacbon ban đầu được giải phóng dưới dạng khí $\left(\mathrm{CO}, \mathrm{CO}_{2}\right)$ hay các chất hữu cơ nhẹ (ví dụ các hợp chất phenol, acetic axit, các chất thơm). Trong một số trường hợp, một lượng nhỏ chấu chứa lưu huỳnh như DMSO-2 xuất hiện trong hỗn hợp các chất hữu cơ nhẹ (các hợp chất chứa lưu huỳnh được hình thành ở nhiệt độ dưới $400^{\circ} \mathrm{C}$ ). Phần còn lại của humin có hoạt tính thấp trong môi trường khí hóa bằng hơi nước hay $\mathrm{CO}_{2}$, vì vậy mà khí hóa humin cần nhiệt độ rất cao (trên $1050^{\circ} \mathrm{C}$ ). Do đó việc sử dụng chất xúc tác là yêu cầu thiết yếu để tăng tốc độ phản ứng của humin, giảm nhiệt độ khí hóa và năng lượng cung cấp cho quá trình này. 
Các muối kiềm có hoạt tính cao đối với quá trình khí hóa sinh khối nói chung. Đối với quá trình khí hóa humin, $\mathrm{Na}_{2} \mathrm{CO}_{3}$ có hoạt tính cao nhất và được chọn để nghiên cứu sâu hơn. Năng lượng hoạt hóa của humin trong quá trình khí hóa bằng $\mathrm{CO}_{2}$ với xúc tác $\mathrm{Na}_{2} \mathrm{CO}_{3}$ cũng tương đương với năng lượng hoạt hóa của than từ thực vật. Nghiên cứu về động học của phản ứng khí hóa bằng hơi nước hay $\mathrm{CO}_{2}$ chỉ ra rằng tốc độ phản ứng khá ổn định trong một khoảng rộng giá trị chuyển hóa (hay nói cách khác giá trị chuyển hóa tỷ lệ thuận với thời gian phản ứng) và quá trình khí hóa dị thể với xúc tác tương đồng với phản ứng đồng thể. Trong quá trình khí hóa bằng hơi nước sử dụng $\mathrm{Na}_{2} \mathrm{CO}_{3}$ là xúc tác, phần còn lại của humin ở nhiệt độ cao (trên $\left.700{ }^{\circ} \mathrm{C}\right)$ bị khí hóa hoàn toàn $\left(75 \%\right.$ thành $\mathrm{CO}$ và $25 \%$ thành $\mathrm{CO}_{2}$, tỷ lệ $\mathrm{H}_{2} / \mathrm{CO}$ xấp xỉ bằng 2). Tuy nhiên, $\mathrm{Na}_{2} \mathrm{CO}_{3}$ bị thất thoát vào pha khí do bị biến đổi thành các chất linh động và dễ bay hơi như $\mathrm{Na}, \mathrm{Na}_{2} \mathrm{O}_{2}$. Việc bổ sung $\mathrm{CO}_{2}$ vào dòng khí cung cấp cho quá trình phản ứng có thể làm tăng đáng kể độ bền vững của xúc tác. Do đó, trong thiết kế quá trình, sự kết hợp khí hóa bằng hơi nước với $\mathrm{CO}_{2}$ là yêu cầu thiết yếu. Năng suất $\mathrm{H}_{2}$ có thể được tăng thêm bằng việc kết nối quá trình ôxy hóa $\mathrm{CO}$ bằng hơi nước (phản ứng WGS) sau quá trình khí hóa. Bản chất của các hợp chất natri đóng vai trò xúc tác được nghiên cứu trong điều kiện phản ứng khí hóa bằng $\mathrm{CO}_{2}$ với việc sử dụng đồng vị $\mathrm{Na}_{2}{ }^{13} \mathrm{CO}_{3}$ và ${ }^{23} \mathrm{Na}$ cộng hưởng từ chất rắn. Việc sử dụng các kĩ thuật này chỉ ra rằng natri cacbonat tồn tại ở trạng thái hỗn hợp ôxit hoặc cacbonat ở điều kiện khí hóa.

Để nâng cao tối đa việc sự dụng nguồn cacbon trong humin cũng như làm sạch dòng khí sản phẩm, việc loại bỏ các sản phẩm nhựa hữu cơ từ humin theo con đường ôxy hóa bằng hơi nước là cần thiết. Phần hai của Luận án (Chương 5 và 6 ) tập trung vào sự tổng hợp xúc tác dựa trên niken cho quá trình ôxy hóa bằng hơi các sản phẩm dạng nhựa hữu cơ từ humin. $\mathrm{Ba}$ loại xúc tác bao gồm niken được ổn định trên hỗn hợp ceria-zirconia được phát triển, chú trọng tới sự ảnh hưởng của phương pháp tổng hợp hỗn hợp chất nền đến hoạt tính của xúc tác. $m$-cresol và acetic axitđược lựa chọn là chất đại diện cho hỗn hợp nhựa hữu cơ từ humin vì các chất này chứa hầu hết các nhóm chức có mặt trong hỗn hợp này. Hỗn hợp ôxit ceriazirconia có tính chất hóa khử tốt và có thể đóng góp vào việc ôxy hóa cốc (coke) hình thành trên bề mặt xúc tác, do đó ngăn ngừa sự giảm hoạt tính của xúc tác. Ba loại chất nền chứa hỗn hợp ceria-zirconia được tổng hợp theo phương pháp đồng kết tủa, đồng kết tủa kết hợp với nhiệt thủy phân và tẩm ceria trên zirconia và được phân tích. Đối với quá trính oxy hóa $m$ cresol bằng hơi nước, xúc tác niken trên chất nền ceria-zirconia tổng hợp theo phương pháp đồng kết tủa kết hợp nhiệt thủy phân có hoạt tính và độ bền cao nhất. Kết quả từ việc phân tích xúc tác chưa và đã qua sử dụng cũng như kết quả từ nghiên cứu quá trình phản ứng bằng phổ hồng ngoại (FT-IR) giúp làm sáng tỏ tính chất và khả năng hoạt động của các loại xúc tác. 
Đối với phản ứng oxy hóa $m$-cresol, nickel đóng vai trò chính trong việc phá vỡ các liên kết $\mathrm{C}-\mathrm{C}$ và $\mathrm{C}-\mathrm{H}$ (của phân tử $m$-cresol). Kết quả từ nghiên cứu in situ FT-IR của phản ứng này chỉ ra rằng vòng thơm của $m$-cresol được hấp phụ trên bề mặt hạt nickel theo phương song song và nhóm methyl tương tác với chất nền. Điều này cho phép việc phá vỡ các liên kết trong phân tử m-cresol có thể thực hiện đồng thời. Do vậy, kích thước tinh thể nickel tương đối lớn (trong ngưỡng tối ưu) có thể có lợi hơn cho phản ứng.

Vì acetic axit là chất hữu cơ không thơm phổ biến nhất trong hỗn hợp nhựa hữu cơ từ humin, khả năng hoạt động của chất xúc tác tối ưu cho m-cresol đối với quá trính oxy hóa acetic axit bằng hơi nước cũng cần được xem xét. Do acetic axit rất dễ gây giảm và mất hoạt tính của xúc tác, nghiên cứu phản ứng oxy hóa acetic axit bằng hơi được tập trung vào tính bền vững, ổn định của chất xúc tác đối với phản ứng này. Sự gia tăng hoạt tính ở xúc tác được tái sử dụng được nhận biết và làm sáng tỏ dựa trên các kết quả phân tich xúc tác bằng nhiều kỹ thuật (ví dụ LEIS - tán xạ năng lượng ion thấp, phổ Raman, oxy hóa/khử theo nhiệt độ). Sự biến đổi liên kết kim loại với oxy của chất nền (Ce-O hay Zr-O) xảy ra trong môi trường oxy hóa khử hoặc trong điều kiện phản ứng, đặc biệt là ở trường hợp sau. Kết quả trên cũng chỉ ra rằng các điểm hoạt tính tăng thêm nằm gần với hạt nickel. Tại các vị trí này, phân tử acetic acid mất proton bị hấp phụ lên bề mặt chất nền và chuyển hóa theo con đường loại nước. Tính linh động của oxy trên chất nền là yếu tố cốt yếu cho việc ngăn ngừa việc hình thành cốc (coke) trên xúc tác, do đó tăng cường hoạt tính và độ bền, ổn định của xúc tác.

Để kết luận, toàn bộ quá trình khí hóa humin đã được nghiên cứu trong luận văn này. Humin là nguồn nguyên liệu cacbon triển vọng cho quá trình sản xuất hydro "xanh". Luận văn bao gồm nghiên cứu cơ bản về cấu trúc hóa học của humin - sản phẩm phụ từ quá trình tách nước của D-glucose để sản xuất levulinic axit (một hợp chất tổng hợp cơ bản từ sinh khối) cũng như toàn bộ quá trình khí hóa (nhiệt phân humin ban đầu, khí hóa phần còn lại của humin, oxy hóa bằng hơi nước sản phẩm phụ dạng nhựa hữu cơ). Kết quả từ nghiên cứu này cũng có thể đóng góp và áp dụng cho việc khí hóa một khoảng lớn nguyên liệu có nguồn gốc từ sinh khối thực vật (ví dụ, ligno-xenlulo, dầu từ nhiệt phân sinh khối). 


\title{
Opportunity from problem: sustainable hydrogen for biorefinery from humin by-products of sugar conversion
}

\begin{abstract}
Lignocellulosic biomass is addressed as sustainable alternative feedstock for chemicals and fuels. The concept of biorefinery consists of integrated approaches for conversion of biomass to such products. Top value added chemical platforms from carbohydrates were proposed. Formation of humin by-products is one of the major problem of de-hydration of sugars for making 5-hydroxy methyl furan and levulinic acid (two of the top 10 top valued added bio-derived building blocks). On the other hand, there is high demand of sustainable hydrogen for making bio-chemicals and bio-fuels. Generating hydrogen from humin can improve the use of carbon in biomass as well as the environmental factor of the sugar conversion.
\end{abstract}




\subsection{Biorefinery}

From early history of human-being until the end of $19^{\text {th }}$ century when mankind turned into the modern era, the carbon utilisation in the global economy and technology was based on biomass derived materials or feedstocks. Wood, extracts from biomass or animals (e.g., vegetable oils, bee wax, whale tallow etc.) used to be the only supply source for energy and fuels in daily life until early modern time. The first mobile engines in automobile industry were designed for using biomass derived liquid fuels: e.g., the first internal combustion engine invented by Nikolaus August Otto used ethanol and the first compression ignition engine by Rudolph Diesel was demonstrated with peanut oil in 1898. Thus, energy and transportation fuels from biomass are not a recent discovery. The last century witnessed the dramatic development of life standards which is based on petroleum economy. Since its emergence in the early $20^{\text {th }}$ century, tremendous technological advances and scientific research have established and optimised petroleum processes for energy, fuels and chemicals. However, the depletion of crude oil resources simultaneous with increased demands as result of improved living standards has generated great interest in alternative resources.

Along with the increased use of fossil materials, the global temperature has been increasing in the last century at a rate that by far surpasses the natural variability of the past 1000 years [1]. The emissions of greenhouse gas (e.g., $\mathrm{CH}_{4}, \mathrm{CO}_{2}, \mathrm{~N}_{2} \mathrm{O}$ ) caused by human activities such as burning fossil fuels, is responsible for this anthropogenic global warming. Reduction of greenhouse emissions is now a top priority globally, especially in the developed regions of the world. For example, legislations regarding reduction of $\mathrm{CO}_{2}$ emissions has already been initiated. Sustainability becomes an important requirement for the strategy of energy/chemicals production and consumption. Several alternative resources including wind, tide, photovoltaic, biomass have been investigated in an attempt to replace fossil feedstocks (i.e., crude oil, natural gas and coal), and reduce $\mathrm{CO}_{2}$ emissions. Among these, biomass is the only alternative that is considered as the sustainable alternative, containing carbon, for our fuels, chemicals and materials [2-6]. The concept of a bio-refinery has been introduced and considered as the key to use biomass as raw materials for renewable industry [7-9]. It is analogous to the current petroleum refineries. Generally, biorefinery includes intergraded approaches to convert biomass for multiple applications involving bio-energy, bio-fuels and bio-chemicals. A simplistic, idealised biorefinery flow-chart is shown in Figure 1.1 with specific preference to biofuels and bio-chemicals [2, 6-8, 10-14]. Table 1.1 summarises some targets of bio-based products for major markets in the world [7]. 


\begin{tabular}{|l|l|l|l|}
\hline Table 1.1. Target of bio-based products for major markets in the world [7] \\
\hline USA & 2010 & 2020 & 2030 \\
\hline $\begin{array}{l}\text { Bio-energy: biomass share of electricity } \\
\text { and heat demand in utilities and industry }\end{array}$ & $\begin{array}{l}4 \% \\
\left(3.38 \times 10^{24} \mathrm{~kJ}\right)\end{array}$ & $\begin{array}{l}5 \% \\
\left(4.22 \times 10^{24} \mathrm{~kJ}\right)\end{array}$ & $\begin{array}{l}5 \% \\
\left(4.22 \times 10^{24} \mathrm{~kJ}\right)\end{array}$ \\
\hline $\begin{array}{l}\text { BioFuels: biomass share of demand for } \\
\text { transportation fuels }\end{array}$ & $\begin{array}{l}4 \% \\
\left(1.37 \times 10^{24} \mathrm{~kJ}\right)\end{array}$ & $\begin{array}{l}10 \% \\
\left(4.22 \times 10^{24} \mathrm{~kJ}\right)\end{array}$ & $\begin{array}{l}20 \% \\
\left(10 \times 10^{24} \mathrm{~kJ}\right)\end{array}$ \\
\hline BioProducts: share of target chemicals & $12 \%$ & $18 \%$ & $25 \%$ \\
\hline EU and Germany & 2005 & 2010 & $2020-2050$ \\
\hline $\begin{array}{l}\text { Bioenergy: share of wind power, photovoltaic, } \\
\text { biomass and geothermal electricity and heat } \\
\text { demand in utilities and industry }\end{array}$ & - & $12.5 \%$ & $\begin{array}{l}26 \%(2030) \\
58 \%(2050)\end{array}$ \\
\hline $\begin{array}{l}\text { Biofuels: biomass share of demand in } \\
\text { transportation (petrol and diesel fuels) }\end{array}$ & $1.8 \%$ & $5.75 \%$ & $20 \%(2020)$ \\
\hline Bio-based Products Share of target chemicals & - & - & - \\
\hline
\end{tabular}

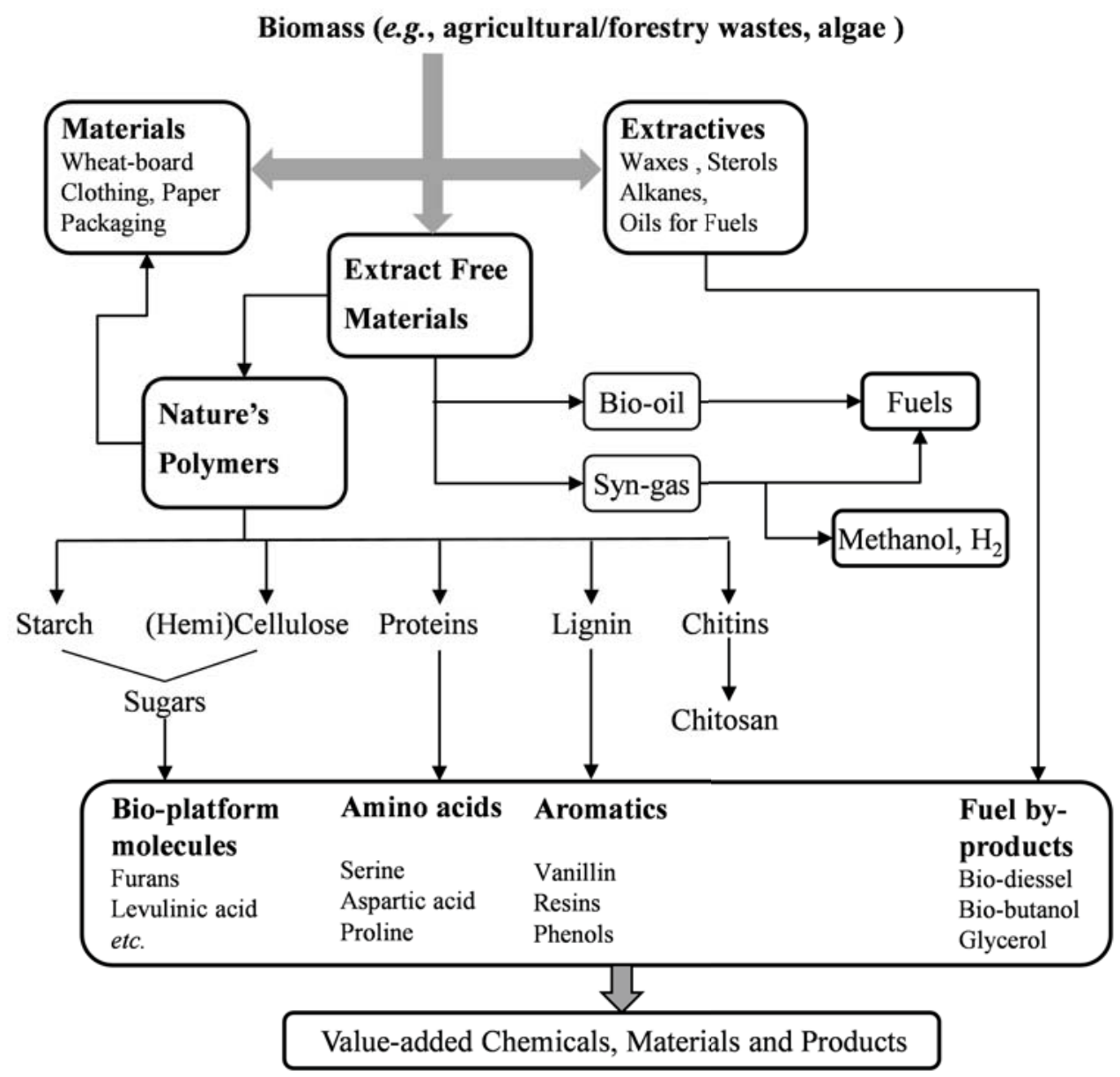

Figure 1. 1. Biorefinery flowchart based on the scheme presented by Clark et al. [2] with regards to bio-chemicals and bio-fuels 


\subsection{Top value added bio-platform molecules}

Today petroleum refinery is based on fractionation of hydrocarbons, and functionalisation of these for making commodity chemicals which can be further converted to a wide range of applications in fuels, pharmaceuticals, domestic products etc. In contrast to the identical, standard and relatively consistent feedstocks in petroleum refinery, biomass is much more diverse and its composition varies from species, locations and seasons. Moreover, the bio-derived molecules are highly functionalised and oxygenated. Therefore, it is challenging to directly transfer our knowledge and experiences gained from petroleum refinery and apply to biorefinery. In spite of this, scientists have made tremendous efforts to establish basic bio-derived platforms and commodity chemicals as well as their conversion routes from biomass using existing knowledge [9-11, 13, 15-18]. However, basic ideas to design appropriate solutions for biorefinery are still at research and development stages. Cellulose and hemicelluloses, comprising $70-80 \mathrm{wt} . \%$, are the largest constituents of lignocellulosic biomass [15, 19]. Hence, conversion of these (hemi)celluloses, consisting of carbohydrate units, is crucial in the bio-refinery [7, 12]. In 2004, the US Department of Energy (DOE) published a report of top value added chemicals from carbohydrates. The embraced platform chemicals were selected based on factors, such as available existing technology and versatility of the compound to serve as a building block for production of wider derivatives with potential markets [13]. Later in 2010, a revised version of this guideline (The "Top $10+4$ ") was published which added more criteria, taking into account extensive newer literature, multiple product applicability, possibility of direct substitution, scope for industrial scale-up etc. [14]. The revised Top Ten bio-platform molecules from carbohydrates include:

- Ethanol

- Furans (furfural, HMF, FDCA)

- Glycerol and derivatives

- Bio-hydrocarbons

- Lactic acid
- Hydroxy propionic acid/aldehyde

- Succinic acid

- Levulinic acid

- Sorbitol

- Xylitol

Furans (e.g., hydroxymethyl furfural - HMF, furfural - FF) and levulinic acid (LA) are among this top list of bio-based primary building blocks $[13,14]$. A wide range of chemicals used as solvents, fuels, monomers etc. can be produced from those platform molecules. Examples of derivatives from furans and LA as well as their applications are illustrated in Figure 1.2. These products are typically made by dehydration of sugars derived from carbohydrates. Even though the preparation of HMF or LA via dehydration of fructose was 
already reported in 1970's [20-23], research on this topic has drawn intensive interest after the DOE's report and especially due to the potential to produce transportation fuels from carbohydrates as stated in a paper in Science [11] by Dumesic and co-workers. Details about synthesis and processing of HMF were excellently discussed in a recent review by Van Putten et al. [24].

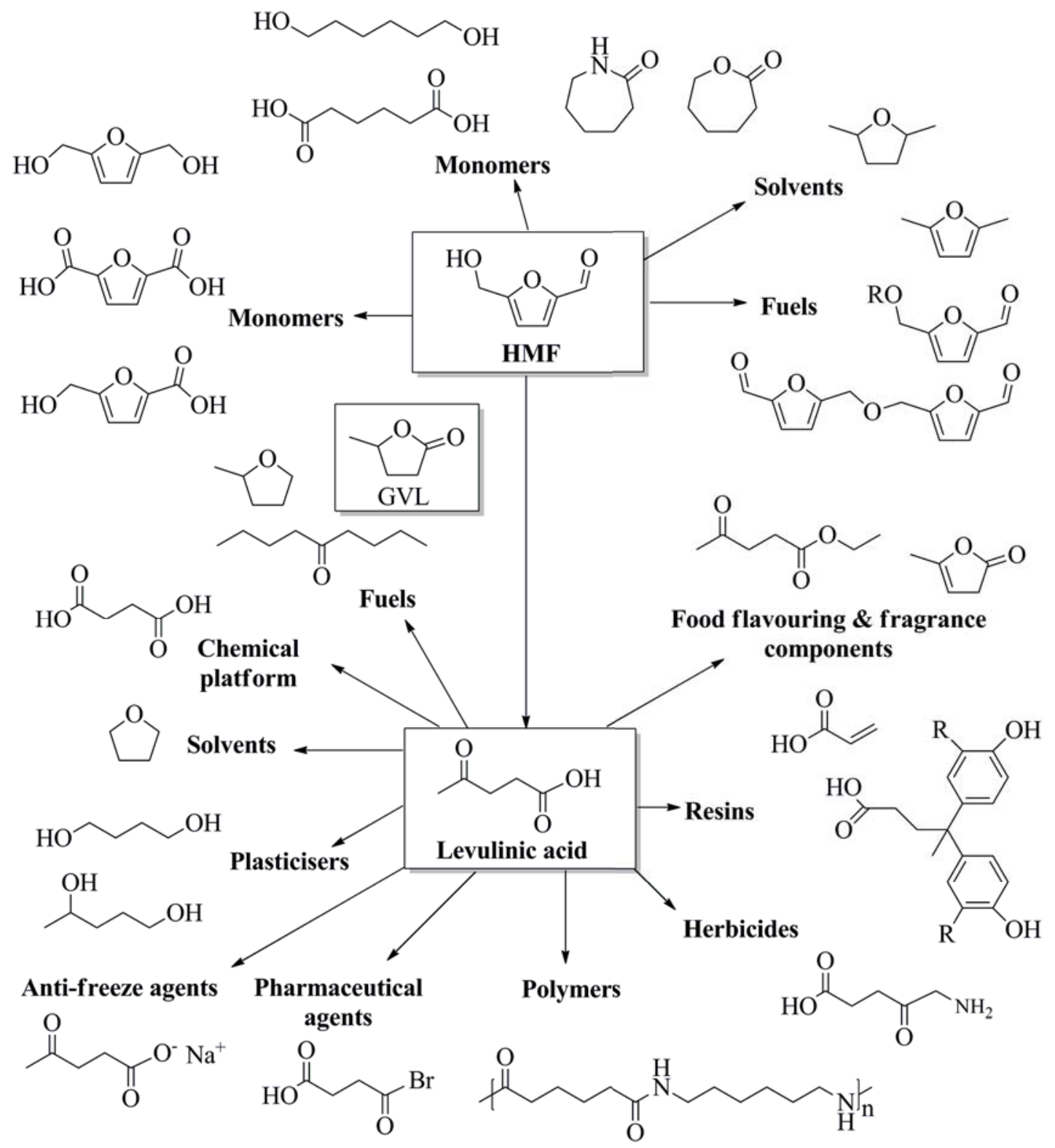

Figure 1.2. HMF and levulinic acid as chemical platform

\subsection{Humin formation}

The pathways to convert lignocellulosic biomass to the above platform chemicals include, separation of poly-saccharides from biomass, hydrolysis of the polysaccharides to 


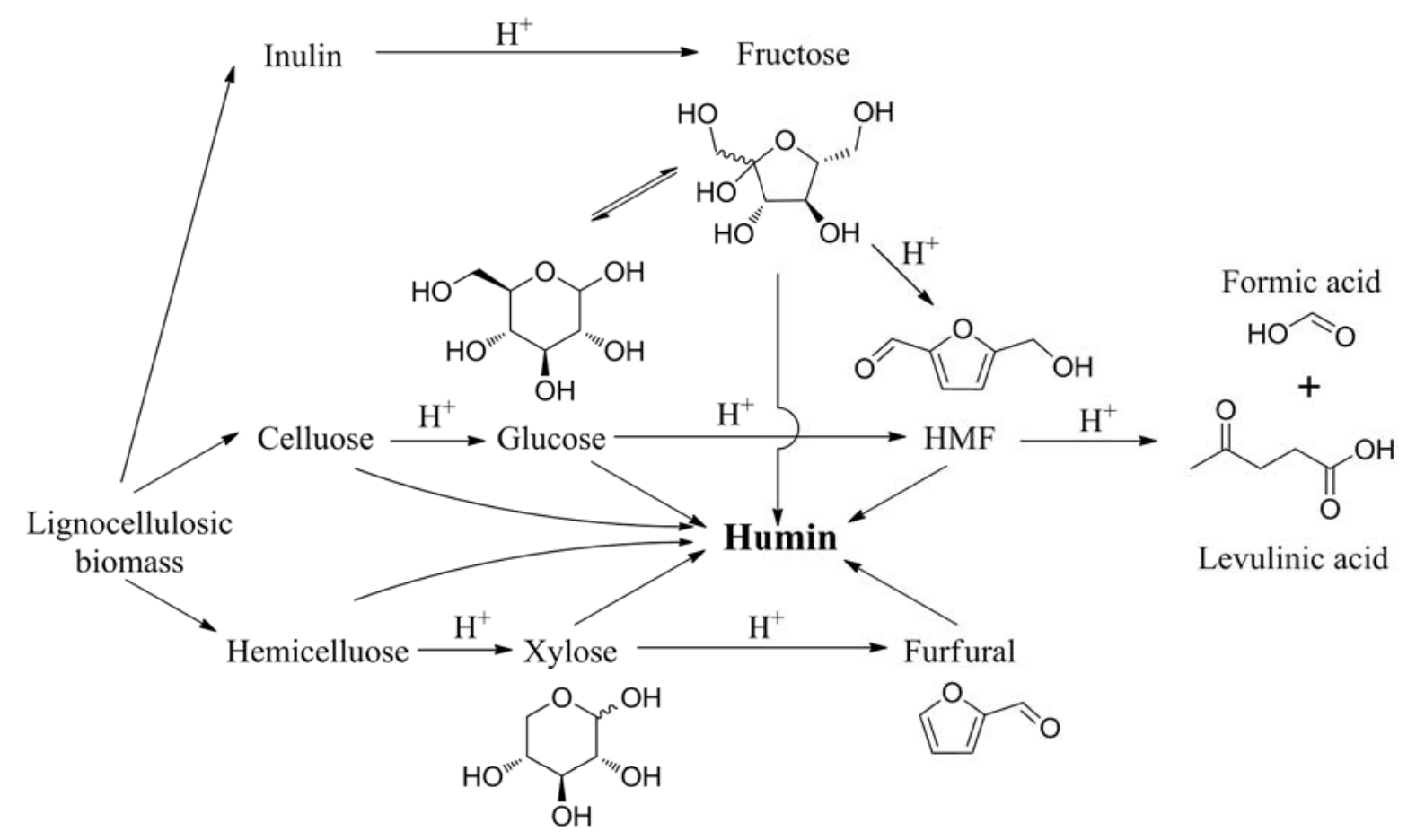

Scheme 1.1. Formation of humin from biomass via dehydration

oligomer/mono carbohydrates (sugars) and dehydration of sugars. Both hydrolysis and dehydration reactions are conventionally performed in aqueous phase using acid catalysts [10, 19]. One of the major problems of these acid catalysed aqueous processes is the formation of large amounts of soluble and insoluble polymeric side-products, generally called as soluble humin and humin, respectively. The latter is sometimes also called humin-like substance, char or coke. Formation of humin during synthesis of HMF and LA via dehydration of sugars is illustrated in Scheme 1.1. In addition, some recent studies on $\mathrm{HMF} / \mathrm{FF} / \mathrm{LA} / \gamma$-valerolactone (GVL) synthesis from carbohydrates are summarised in Table 1.2. As can be seen, the selectivity to humin depends on substrates used, catalysts, reaction medium, temperature etc. When the reaction is carried out in aqueous phase, the selectivity to humin can be as high as $50 \%$ on carbon basis. The formation of humin is more severe with glucose than fructose. Unfortunately, glucose is the most abundant monosaccharide present in lignocellulose; in fact D-glucose is the only monomer of cellulose. Much effort has been made to supress the formation of humin (see Table 1.2). Most used options include performing the dehydration in: (i) organic solvents (e.g., DMSO), (ii) ionic liquids or (iii) biphasic systems (aqueous/organic solvent). Another option is combining the dehydration with esterification/ etherification of the product, HMF or LA, to stabilise it against secondary conversions. In the esterification/etherification approach, HMF or LA interacts with an alcohol (e.g., methanol, ethanol; alcohol/water varies 4.5 - 10) forming ester or ether, respectively, thus blocking the 
reactive functionalities in order to avoid further condensation reactions. The biphasic system employs, beside water, organic solvents such as toluene, benzene, IMBK, THF. They extract $\mathrm{HMF} / \mathrm{FF}$ rapidly from the aqueous phase, minimising the condensation reaction between sugar substrate and HMF/FF. Although use of an organic solvent or ionic liquid improves the selectivity to HMF or LA substantially, separation of the products from the reaction medium remains a challenge. In addition, low concentration of the products formed (LA, HMF) and their higher boiling points compared to solvent (alcohol) makes separation/purification energy intensive and expensive.

Recently, Alonso et al.[25] proposed a green, conceptual process using alkyl-phenol, derived from lignin, as the organic solvent. The advantage includes its higher boiling point and stability in the sulphuric acid reaction medium. Further, alkyl-phenol is also suitable as medium for the hydrogenation of LA to GVL - a bio-based fuel. Therefore, the synthesis of HMF/LA via homogeneous acid catalysed aqueous route is still of interest. However, conceptual design of both the Biofine process (a commercial pilot plant, reference [26], Table 1.2) and the process proposed by Alonso et. al still produce 25-45 wt.\% of humin. Valorisation of this by-product is therefore crucial for making the whole biomass conversion economical and environmentally viable.

\subsection{Hydrogen in biorefinery}

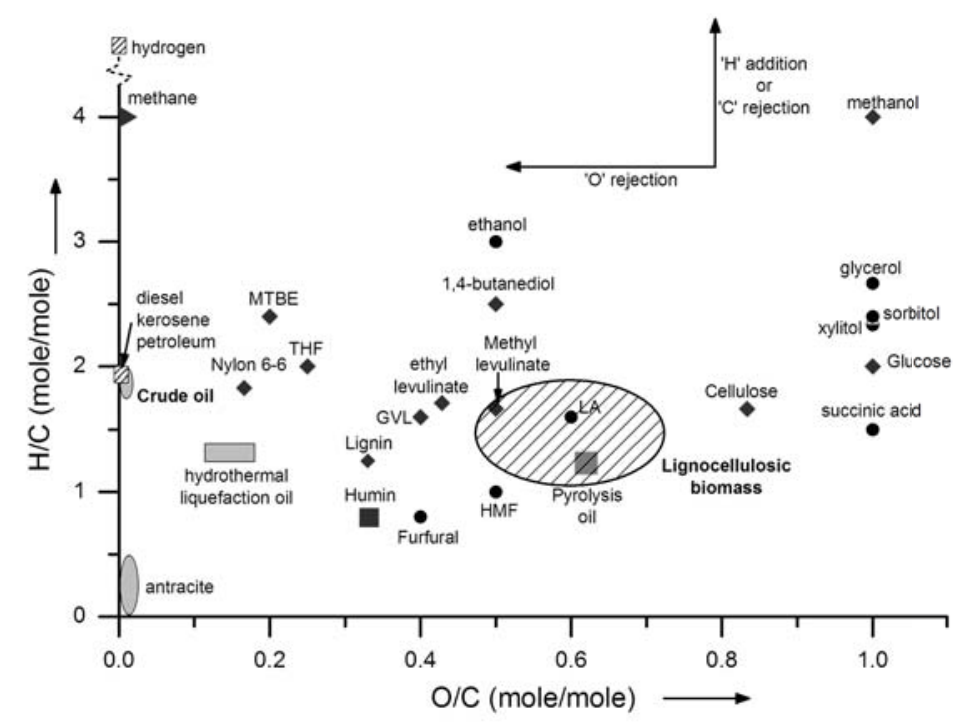

Figure 1.3. Composition (dry basis) of fossil and biomass feedstocks and fuels/chemicals derived from them

Biomass and bio-derived chemical platforms have high oxygen contents. Figure 1.3 shows the composition of major bio-derived feedstocks and top value added platforms from 


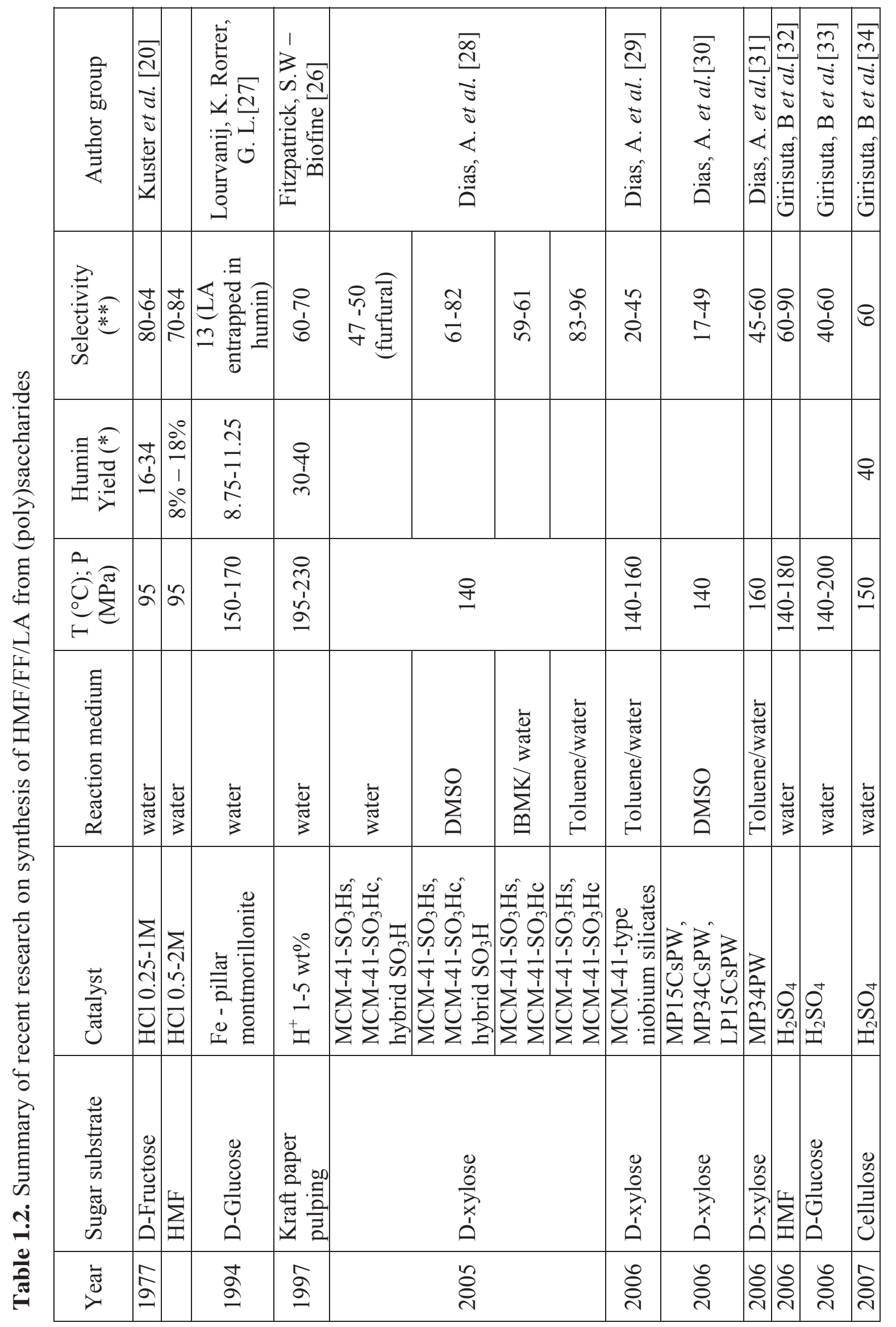


Opportunity from problem: sustainable $\mathrm{H}_{2}$ from humin based by-products of sugar conversion $\quad 9$

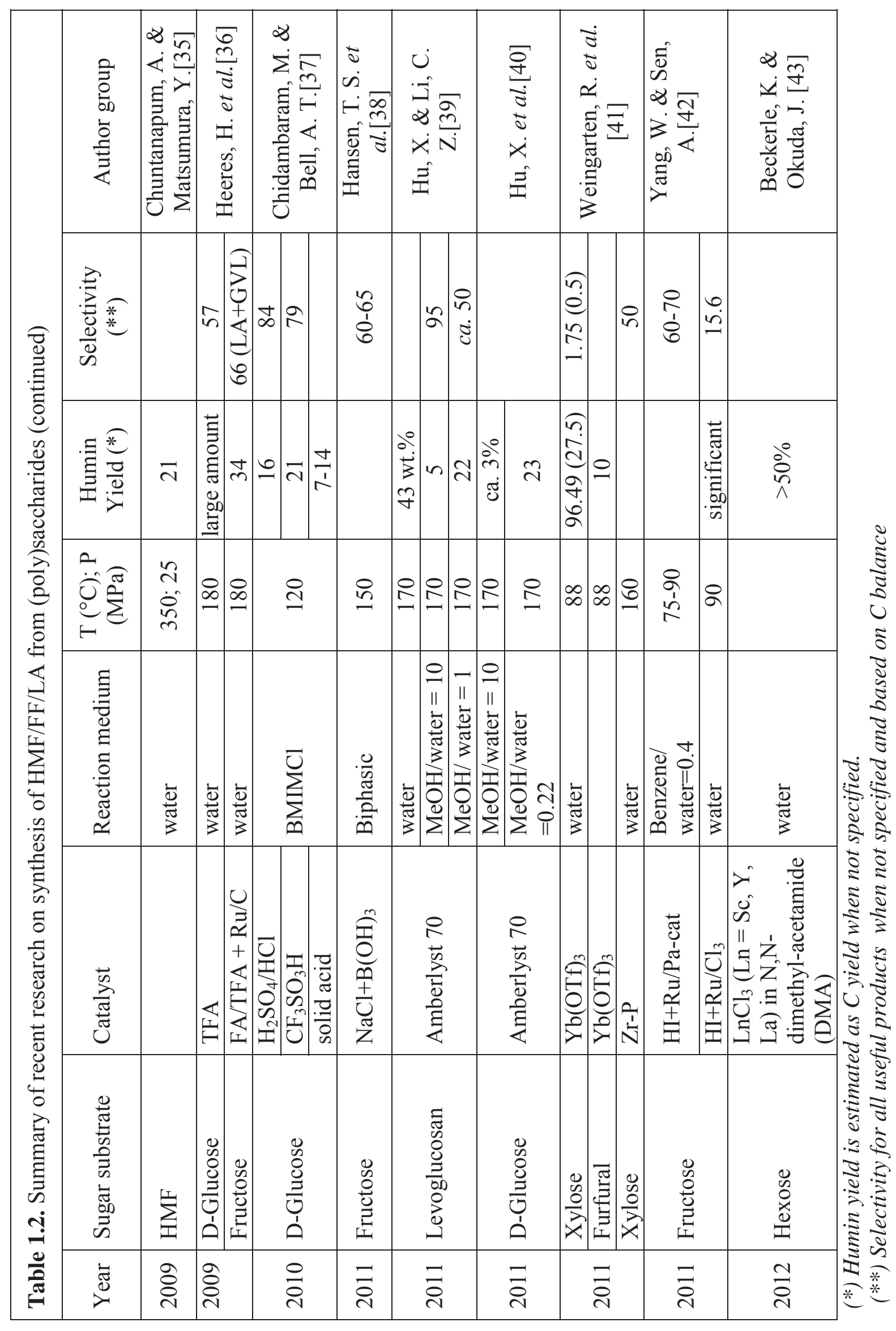




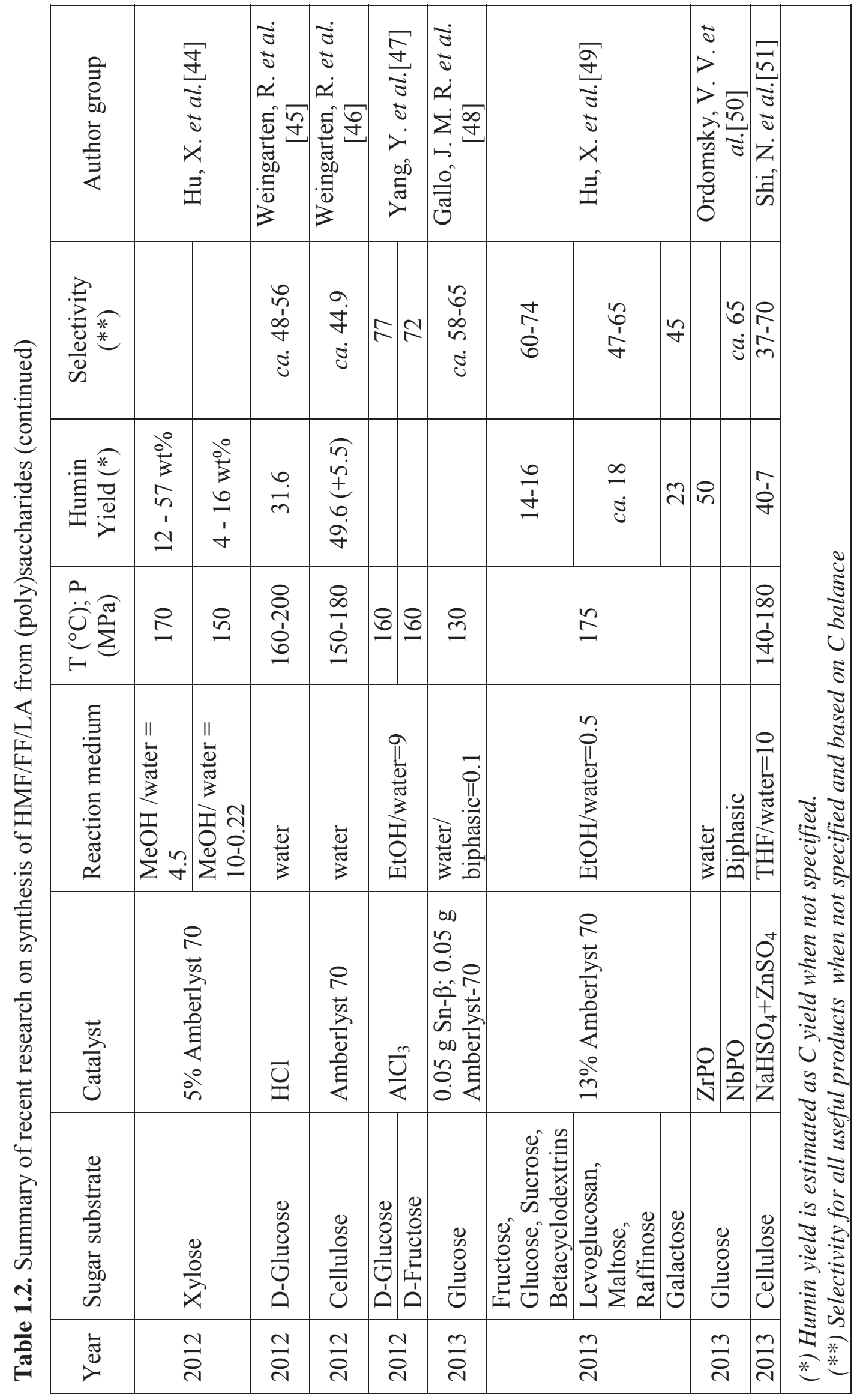


carbohydrates on a Van Krevelen diagram (i.e. $\mathrm{H} / \mathrm{C}$ vs. $\mathrm{O} / \mathrm{C}$ ). Fossil fuels, commodity chemicals and feedstocks are also included for comparison. Conventional fuel blends have very low amounts of oxygen which mainly come from additives. In order to make the biobased fuels and chemicals compatible with today's transportation engines or materials, respectively, reduction of oxygen and increase of hydrogen content is essential. Such deoxygenation can be achieved via hydro-de-oxygenation (e.g., upgrading of pyrolysis oil). Moreover, hydrogenation treatment is widely used in biomass processing (e.g., hydrogenation of LA to GVL, methyl tetra-furan, glucose to sorbitol etc.). Therefore, the demand for hydrogen is ubiquitous in biorefinery [52].

Hydrogen can be produced from fossil fuels (e.g., natural gas, coal), water and biomass [53]. Currently, hydrogen is mainly generated from steam reforming of methane or gasification of coal. These processes use fossil feedstocks and release large amounts of $\mathrm{CO}_{2}$ which contributes to the greenhouse gas problem. Of the 48 million metric tons of $\mathrm{H}_{2}$ globally produced from fossil fuels, about $50 \%$ is consumed for ammonia synthesis, used in fertiliser industry, $37 \%$ is in hydro-treating petroleum processes and a small part for food industry (e.g., hydrogenation of edible oil). It is forecasted that hydrogen demand will increase in the next decade because of the increasing demand in fertilisers and also use of hydrogen for fuel cells (mainly in hybrid cars) and biorefinery. On the other hand, for the production of biofuels or chemicals, it is mandatory to minimise the use of hydrogen from external sources especially from fossil resources [52]. Production of hydrogen from water splitting (e.g., photochemical/biological water decomposition, electrolysis coupled with photovoltaic cells or wind turbines) is believed to be either in infant stages of development or economically unattractive in the short term future [54-57]. Sustainable hydrogen from biomass based feedstocks via gasification is prohibitively expensive and considered as potentially comparable with the conventional fossil based hydrogen only in the scenario [56] when sequestration of $\mathrm{CO}_{2}$ is included.

Technologies to convert biomass to hydrogen includes direct gasification, liquefaction (e.g., pyrolysis or high pressure liquefaction) followed by steam reforming [53]. Biomass gasification is similar to coal gasification except that the gasification temperature can be lower since biomass contains more functionalised (oxygenate) chemical structure which makes it more reactive than coal $[58,59]$. Gasification of biomass can be performed at temperatures above $700{ }^{\circ} \mathrm{C}$ in the presence of oxygen/air or steam [58]. In the case of gasification using oxygen (partial oxidation) or auto-thermal gasification (using oxygen and steam), use of pure oxygen is preferable. This also requires application of high temperatures typically above $1000{ }^{\circ} \mathrm{C}$ and use of oxygen via the costly air separation. In addition, the 
disadvantage of these methods also includes difficulty in process control (e.g., supplying gas mixture evenly to avoid local overheating, full oxidation etc.).

Biomass is unstable under the elevated temperatures required for gasification. The reactions stages of a typical gasification process using steam as oxidant is shown in Figure 1. 4. First, biomass is pyrolysed and decomposed to form gas, oxygenate vapour and char. The oxygenate vapour further experiences secondary reactions which cause the formation of light hydrocarbons $\left(\mathrm{C}_{1}-\mathrm{C}_{4}\right)$ and $\operatorname{tar}[55,60]$. The steam reforming of biomass is actually the steam reforming of tar and bio-char. Significant amounts of tar in the product gas which mainly consists of oxygenate, phenols, (poly)aromatics [59, 61] can still be present even at high gasification temperature (i.e., $800-1000{ }^{\circ} \mathrm{C}$ ). Selectivity of unconverted char is about $10-$ $25 \%$ on carbon basis $[56,62,63]$.

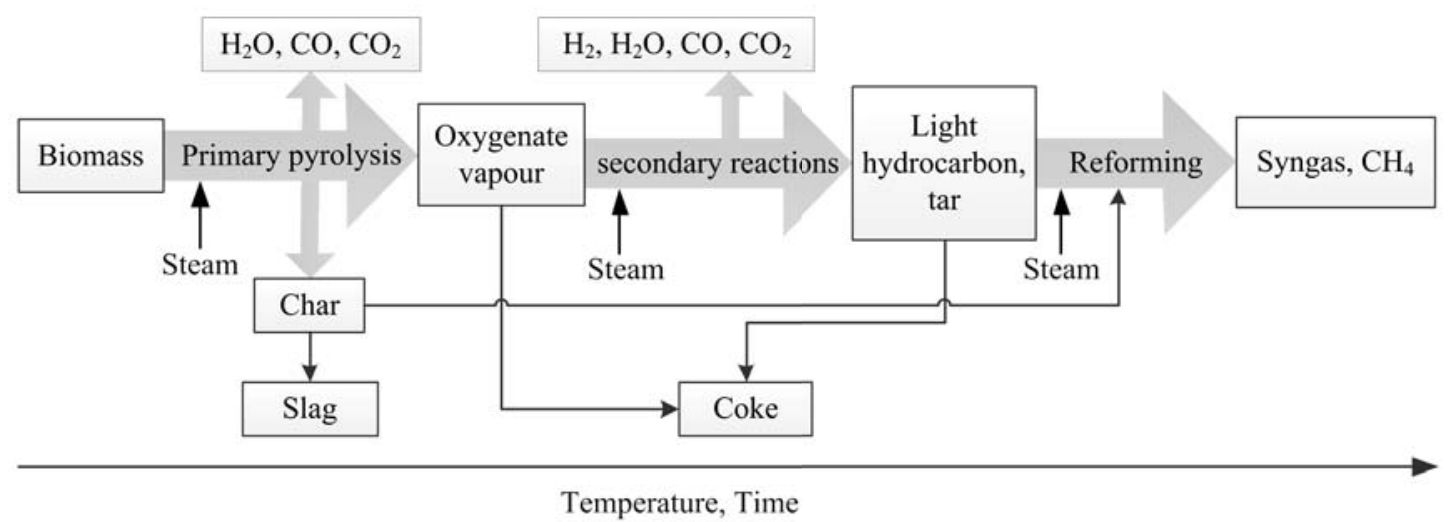

$$
\begin{array}{ll}
\text { Biomass }\left(\mathrm{C}_{\mathrm{x}} \mathrm{H}_{\mathrm{y}} \mathrm{O}_{\mathrm{z}}\right) \stackrel{\text { temperature }}{\longrightarrow} \mathrm{C}_{\mathrm{x}^{\prime}} \mathrm{H}_{\mathrm{y}^{\prime}} \mathrm{O}_{\mathrm{z}^{\prime}}+\mathrm{CO}+\mathrm{CO}_{2}+\mathrm{H}_{2} \mathrm{O} & (1 \text { - pyrolysis }) \\
\mathrm{C}_{\mathrm{x}^{\prime}} \mathrm{H}_{\mathrm{y}^{\prime}} \mathrm{O}_{\mathrm{z}^{\prime}} \stackrel{\text { temperature }}{\longrightarrow} \mathrm{C}_{\mathrm{m}} \mathrm{H}_{\mathrm{n}}+\mathrm{CO}+\mathrm{CO}_{2}+\mathrm{H}_{2} \mathrm{O}+\mathrm{H}_{2}+\text { tar } & (2) \\
\mathrm{tar}+\mathrm{H}_{2} \mathrm{O} \stackrel{\text { temperature }}{\longrightarrow} \mathrm{CO}+\mathrm{H}_{2} & (3-\text { steam reforming }) \\
\mathrm{C}_{\mathrm{m}} \mathrm{H}_{\mathrm{n}}+\mathrm{H}_{2} \mathrm{O} \stackrel{\text { temperature }}{\longrightarrow} \mathrm{CO}+\mathrm{H}_{2} & (5 \text { - steam reforming }) \\
\mathrm{C}(\text { coke or char })+\mathrm{H}_{2} \mathrm{O} \stackrel{\text { temperature }}{\longrightarrow} \mathrm{CO}+\mathrm{H}_{2} & (6 \text { - water gas shift }) \\
\mathrm{CO}+\mathrm{H}_{2} \mathrm{O} \rightarrow \mathrm{CO}_{2}+\mathrm{H}_{2} & (7 \text { - methanation })
\end{array}
$$

Figure 1.4. Stages and reactions occurring during steam reforming of biomass $[4,59]$ 
Biomass usually contains a small amount of ash in its composition. The ash which comprises mainly $\mathrm{K}_{2} \mathrm{O}, \mathrm{CaO}, \mathrm{MgO}$ can play the role as catalysts for the gasification. Therefore, gasification of biomass is usually performed "thermally", without adding external catalysts. Additional catalyst used for gasification of biomass was well reviewed by Sutton $e t$ al. [64]. They briefly belong to three groups: dolomite, alkali metals and Ni based catalysts. Dolomite can be used as primary catalyst by dry mixing with biomass. However, due to poor contact with biomass, it is commonly used in a downstream reactor as the guard bed for reducing tar in the gas stream. Ni based catalysts are commercially used in steam methane reforming. When mixed directly with biomass, Ni based catalysts rapidly deactivate due to coke and carbon fouling [64]. Therefore, Ni based catalysts are usually used in a secondary bed for tar reforming. Alkali based catalysts, especially $\mathrm{K}_{2} \mathrm{CO}_{3}$, are widely investigated in biomass gasification. Alkali based catalysts (e.g., $\mathrm{Li}_{2} \mathrm{CO}_{3}, \mathrm{~K}_{2} \mathrm{CO}_{3}, \mathrm{Na}_{2} \mathrm{CO}_{3}$ ) are also known to be effective in tar reforming [61, 64]. Due to their natural presence in large amounts in biomass (homogenously distributed), alkali metals are effective for steam gasification of biochar [65-67]. In the case of added catalyst, it can be dry mixed or impregnated directly with biomass. However creation of good contact between solid biomass and the catalyst is still a challenge. Moreover, alkali or alkali earth metal catalysts can evaporate at gasification temperatures, especially in presence of oxygen/steam. They can also cause fouling as well as deactivation of catalysts in the downstream reactor.

\subsection{Scope and outline of the thesis}

Since humin contains about $60 \mathrm{wt} . \%$ carbon $[32,51,68]$, it can be used as feedstock for production of synthesis gas or hydrogen via gasification. Hydrogen, as often stated, is essential in biorefinery [52]. However, minimising the import of $\mathrm{H}_{2}$ from fossil fuels is mandatory [52] for making biofuels/green chemicals. From this point of view, efficient conversion of humin to $\mathrm{H}_{2}$ or syngas $\left(\mathrm{CO}+\mathrm{H}_{2}\right)$ is conceptually attractive. Producing $\mathrm{H}_{2}$ /syngas from humin, which is considered as waste residue, would allow complete use of feedstock carbon in the sugar conversion processes thus enhancing the environmental factor of the process.

The main objective of this thesis is to investigate the potential of humin valorisation via catalytic gasification for sustainable synthesis gas/hydrogen production. The knowledge can thus be used for developing a conceptual process for maximising the use of carbon source. Humin derived from glucose was used as model of humin based by-products from biomass processing. 
Although humin as a by-product has been known for a long time, its chemical structure and properties is not well understood. Generally, it is suggested that humin is a heterogeneous polymeric by-product from carbohydrate conversion which results from the condensation reactions between the carbohydrate (e.g., glucose, fructose) and its intermediates formed during transformation to $\mathrm{HMF} / \mathrm{FF} / \mathrm{LA}$. Further, the influence of gasification conditions on humin structure has not been reported in literature. This thesis comprises of two parts. The first part (Chapter 1 to Chapter 4 ) focuses on understanding the nature of humin as well as gasification of humin residues with steam and $\mathrm{CO}_{2}$. The second part (Chapter 5 and 6) involves the development of $\mathrm{Ni}$ based catalyst for steam reforming of volatiles products released during heating humin to gasification temperatures. Here-below are the details of the thesis:

Chapter 1. Opportunity from problem: sustainable hydrogen for biorefinery from by-products of sugar conversion

The vitals of biorefinery to our future as well as important aspects of the biorefinery concept such as chemical building blocks from carbohydrates, use and production of sustainable hydrogen were described in this chapter. One of the major problems in the dehydration conversion route for carbohydrates - formation of humin based by-products was also addressed. The requirement for improving the value of humin via gasification to produce renewable hydrogen and maximise the use of carbon source in biomass is the motivation of this study.

Chapter 2. Humin based by-products from bio-processing as potential carbonaceous source for synthesis gas production

Understanding the nature and properties of humin obtained from dehydration of Dglucose (the basic, most abundant sugar derived from lignocellulosic biomass) is one of the main objective in this chapter. Various characterisation techniques were employed to investigate the structure of humin as well as its transformations under the dry reforming conditions. The key results of this chapter include the proposed model of humin molecule and the strong influence of thermal treatment (in $\mathrm{CO}_{2}$ ) on humin morphology, structure and properties. At gasification temperatures, humin resembles bio-char and shows poor reactivity in non-catalytic dry reforming. It implies the essential need for a catalyst for the gasification.

Chapter 3. Valorisation of humin based by-products from bio-processing - A route to sustainable hydrogen 
Steam reforming of humin was has been studied by temperature gravimetric analysis. Nature of humin at gasification temperatures is discussed. Various alkali metal and calcium carbonates were screened for the steam reforming. Sodium carbonate which shows the highest activity has been selected for further study on catalyst stability and selectivity of products.

\section{Chapter 4. Kinetics study of dry reforming of humin with $\mathrm{Na}_{2} \mathrm{CO}_{3}$}

Adding $\mathrm{CO}_{2}$ to the reactive gas feed improves the stability of $\mathrm{Na}_{2} \mathrm{CO}_{3}$ catalyst during steam reforming. Kinetics of the catalytic gasification in $\mathrm{CO}_{2}$ for different humin samples (i.e. pristine humin and purified humin) is the main objective of this chapter. Further investigation of the nature of sodium species which might contribute to the catalytic activity was studied using dry reforming with labelled $\mathrm{Na}_{2}{ }^{13} \mathrm{CO}_{3}$ and ${ }^{23} \mathrm{Na}$ MAS-NMR. The data result from these techniques reveals that $\mathrm{Na}_{2} \mathrm{CO}_{3}$ is in the oxide/carbonate form at the gasification temperatures.

By the end of Part 1 of the thesis, the questions on nature of humin and its characteristics under gasification were clarified. The study also demonstrates the potential of hydrogen/synthesis gas production from humin via catalytic gasification. Humin residue (above $700{ }^{\circ} \mathrm{C}$ ) can be gasified with $\mathrm{Na}_{2} \mathrm{CO}_{3}$. However during the pre-heating stage, humin loses $\sim 45 \mathrm{wt} . \%$, which equals to $25 \%$ on carbon basis, into vapour phase in the form of gas and condensable products - tar type products. To maximise the use of carbon source in humin as well as clean the gas stream, removal of these tars via steam reforming is required. Part 2 of the thesis focuses on the development of $\mathrm{Ni}$ based catalyst for steam reforming of the tar products.

Chapter 5. Investigation of Ce-Zr oxide supported Ni catalysts in steam reforming of meta-cresol as model component for bio-derived tar

$m$-Cresol was selected as one of the model components of tar formed during humin gasification. Design an effective supported Ni catalyst using ceria-zirconia based support is described in this chapter. Three ceria-zirconia mixed oxides synthesised via co-precipitation, co-precipitation followed by hydrothermal treatment co-impregnation have been developed and characterised. Ni supported on ceria-zirconia synthesised via co-precipitation followed by hydrothermal treatment shows the most promising for $\mathrm{m}$-cresol reforming Results from characterisation of fresh and used catalyst as well as the FT-IR study on the steam reforming of $\mathrm{m}$-cresol help to explain the performance of the catalysts.

Chapter 6. Steam reforming of acetic acid with nickel supported on ceria-zirconia support 
Since acetic acid is the most abundant aliphatic components in the tar from humin, performance of the optimal catalyst in the steam reforming of acetic acid is of interest, especially with preference to stability of the catalyst. Improvement in activity of recycled catalyst is discussed based on the characterisation results. Redox properties of the ceriazirconia support is observed and clarified. Oxygen mobility of the support is key for preventing coke deposits on the catalyst, thus improved its activity.

\section{Chapter 7. Concluding remarks and outlooks}

Most important remarks resulted from the study were summarised in this chapter. Based on these, a brief conceptual design was proposed. Recommendations for future works were also included in this chapter.

\section{Bibliography}

[1] T.J. Crowley, Causes of climate change over the past 1000 years, Science, 289 (2000) 270-277.

[2] J.H. Clark, F.E.I. Deswarte, T.J. Farmer, The integration of green chemistry into future biorefineries, Biofuel Bioprod Bior, 3 (2009) 72-90.

[3] B.F.M. Kuster, Carbohydr. Res., 54 (1977) 177.

[4] L.H. Zhang, C.B. Xu, P. Champagne, Overview of recent advances in thermo-chemical conversion of biomass, Energy Conversion and Management, 51 (2010) 969-982.

[5] C. Delgado-Andrade, I. Seiquer, M.P. Navarro, F.J. Morales, Mol. Nutr. Food Res., 51 (2007) 341.

[6] A.J. Ragauskas, C.K. Williams, B.H. Davison, G. Britovsek, J. Cairney, C.A. Eckert, W.J. Frederick, Jr., J.P. Hallett, D.J. Leak, C.L. Liotta, J.R. Mielenz, R. Murphy, R. Templer, T. Tschaplinski, The path forward for biofuels and biomaterials, Science, 311 (2006) 484-489.

[7] B. Kamm, M. Kamm, Principles of biorefineries, Applied microbiology and biotechnology, 64 (2004) 137-145.

[8] B. Kamm, P.R. Gruber, M. Kamm, Biorefineries - Industrial Processes and Products, in: Ullmann's Encyclopedia of Industrial Chemistry, Wiley-VCH Verlag GmbH \& Co. KGaA, 2000 .

[9] J.J. Bozell, Feedstocks for the Future - Biorefinery Production of Chemicals from Renewable Carbon, CLEAN - Soil, Air, Water, 36 (2008) 641-647.

[10] G.W. Huber, J.A. Dumesic, An overview of aqueous-phase catalytic processes for production of hydrogen and alkanes in a biorefinery, Catalysis Today, 111 (2006) 119-132. 
[11] G.W. Huber, J.N. Chheda, C.J. Barrett, J.A. Dumesic, Production of liquid alkanes by aqueous-phase processing of biomass-derived carbohydrates, Science, 308 (2005) 1446-1450.

[12] S.G. Wettstein, D.M. Alonso, E.I. Gürbüz, J.A. Dumesic, A roadmap for conversion of lignocellulosic biomass to chemicals and fuels, Current Opinion in Chemical Engineering, 1 (2012) 218-224.

[13] T. Werpy, G. Petersen, Top Value Added Chemicals from Biomass: Volume 1-Results of Screening for Potential Candidates from Sugars and Synthesis Gas, in, National Renewable Energy Laboratory, 2004.

[14] J.J. Bozell, G.R. Petersen, Technology development for the production of biobased products from biorefinery carbohydrates - the US Department of Energy's “Top 10" revisited, Green Chemistry, 12 (2010) 539.

[15] N. Mosier, C. Wyman, B. Dale, R. Elander, Y.Y. Lee, M. Holtzapple, M. Ladisch, Features of promising technologies for pretreatment of lignocellulosic biomass, Bioresource technology, 96 (2005) 673-686.

[16] J.H. Clark, V. Budarin, F.E.I. Deswarte, J.J.E. Hardy, F.M. Kerton, A.J. Hunt, R. Luque, D.J. Macquarrie, K. Milkowski, A. Rodriguez, O. Samuel, S.J. Tavener, R.J. White, A.J. Wilson, Green chemistry and the biorefinery: A partnership for a sustainable future, Green Chemistry, 8 (2006) 853-860.

[17] S. Fernando, S. Adhikari, C. Chandrapal, N. Murali, Biorefineries: Current status, challenges, and future direction, Energy and Fuels, 20 (2006) 1727-1737.

[18] A.M. Ruppert, K. Weinberg, R. Palkovits, Hydrogenolysis goes bio: from carbohydrates and sugar alcohols to platform chemicals, Angew Chem Int Ed Engl, 51 (2012) 2564-2601.

[19] Y. Sun, J. Cheng, Hydrolysis of lignocellulosic materials for ethanol production: a review, Bioresource technology, 83 (2002) 1-11.

[20] B.F.M. Kuster, H. S. van der Baan, The influence of the initial and catalyst concentrations on the dehydration of d-fructose, Carbohydrate research, 54 (1977) 165-176.

[21] B.F.M. Kuster, The influence of water concentration on the dehydration of d-fructose, Carbohydrate research, 54 (1977) 177-183.

[22] B.F.M. Kuster, H.M.G. Temmink, The influence of $\mathrm{pH}$ and weak-acid anions on the dehydration of d-fructose, Carbohydrate research, 54 (1977) 185-191.

[23] M.J. Antal, W.S.L. Mok, G.N. Richards, Kinetic-Studies of the Reactions of Ketoses and Aldoses in Water at High-Temperature .1. Mechanism of Formation of 5-(Hydroxymethyl)-2Furaldehyde from D-Fructose and Sucrose, Carbohydrate research, 199 (1990) 91-109.

[24] R.J. Van Putten, J.C. Van Der Waal, E. De Jong, C.B. Rasrendra, H.J. Heeres, J.G. De Vries, Hydroxymethylfurfural, a versatile platform chemical made from renewable resources, Chemical reviews, 113 (2013) 1499-1597. 
[25] D.M. Alonso, S.G. Wettstein, J.Q. Bond, T.W. Root, J.A. Dumesic, Production of biofuels from cellulose and corn stover using alkylphenol solvents, ChemSusChem, 4 (2011) 1078-1081.

[26] S.W. Fitzpatrick, US5608105 - production of levulinic acid from carbohydrate containing materials, in: U.S. Patent (Ed.), Biofine Incorporated, Wilmington, Del., United States, 1997.

[27] K. Lourvanij, G.L. Rorrer, Dehydration of Glucose to Organic-Acids in Microporous Pillared Clay Catalysts, Appl Catal a-Gen, 109 (1994) 147-165.

[28] A. Dias, M. Pillinger, A. Valente, Dehydration of xylose into furfural over micromesoporous sulfonic acid catalysts, Journal of Catalysis, 229 (2005) 414-423.

[29] A.S. Dias, S. Lima, P. Brandão, M. Pillinger, J. Rocha, A.A. Valente, Liquid-phase Dehydration of d-xylose over Microporous and Mesoporous Niobium Silicates, Catalysis Letters, 108 (2006) 179-186.

[30] A.S. Dias, S. Lima, M. Pillinger, A.A. Valente, Acidic cesium salts of 12tungstophosphoric acid as catalysts for the dehydration of xylose into furfural, Carbohydrate research, 341 (2006) 2946-2953.

[31] A.S. Dias, M. Pillinger, A.A. Valente, Mesoporous silica-supported 12tungstophosphoric acid catalysts for the liquid phase dehydration of d-xylose, Microporous and Mesoporous Materials, 94 (2006) 214-225.

[32] B. Girisuta, L.P.B.M. Janssen, H.J. Heeres, A kinetic study on the decomposition of 5hydroxymethylfurfural into levulinic acid, Green Chemistry, 8 (2006) 701.

[33] B. Girisuta, L.P.B.M. Janssen, H.J. Heeres, A Kinetic Study on the Conversion of Glucose to Levulinic Acid, Chemical Engineering Research and Design, 84 (2006) 339-349.

[34] B. Girisuta, L.P.B.M. Janssen, H.J. Heeres, Kinetic Study on the Acid-Catalyzed Hydrolysis of Cellulose to Levulinic Acid, Industrial \& Engineering Chemistry Research, 46 (2007) 1696-1708.

[35] A. Chuntanapum, Y. Matsumura, Formation of Tarry Material from 5-HMF in Subcritical and Supercritical Water, Industrial \& Engineering Chemistry Research, 48 (2009) 9837-9846.

[36] H. Heeres, R. Handana, D. Chunai, C. Borromeus Rasrendra, B. Girisuta, H. Jan Heeres, Combined dehydration/(transfer)-hydrogenation of C6-sugars (D-glucose and D-fructose) to $\gamma$-valerolactone using ruthenium catalysts, Green Chemistry, 11 (2009) 1247.

[37] M. Chidambaram, A.T. Bell, A two-step approach for the catalytic conversion of glucose to 2,5-dimethylfuran in ionic liquids, Green Chemistry, 12 (2010) 1253-1262. 
[38] T.S. Hansen, J. Mielby, A. Riisager, Synergy of boric acid and added salts in the catalytic dehydration of hexoses to 5-hydroxymethylfurfural in water, Green Chemistry, 13 (2011) 109-114.

[39] X. Hu, C.Z. Li, Levulinic esters from the acid-catalysed reactions of sugars and alcohols as part of a bio-refinery, Green Chemistry, 13 (2011) 1676-1679.

[40] X. Hu, C. Lievens, A. Larcher, C.Z. Li, Reaction pathways of glucose during esterification: effects of reaction parameters on the formation of humin type polymers, Bioresource technology, 102 (2011) 10104-10113.

[41] R. Weingarten, G.A. Tompsett, W.C. Conner, G.W. Huber, Design of solid acid catalysts for aqueous-phase dehydration of carbohydrates: The role of Lewis and Brønsted acid sites, Journal of Catalysis, 279 (2011) 174-182.

[42] W. Yang, A. Sen, Direct catalytic synthesis of 5-methylfurfural from biomass-derived carbohydrates, ChemSusChem, 4 (2011) 349-352.

[43] K. Beckerle, J. Okuda, Conversion of glucose and cellobiose into 5hydroxymethylfurfural (HMF) by rare earth metal salts in N,N '-dimethylacetamide (DMA), J Mol Catal a-Chem, 356 (2012) 158-164.

[44] X. Hu, C. Lievens, C.Z. Li, Acid-catalyzed conversion of xylose in methanol-rich medium as part of biorefinery, ChemSusChem, 5 (2012) 1427-1434.

[45] R. Weingarten, J. Cho, R. Xing, W.C. Conner, Jr., G.W. Huber, Kinetics and reaction engineering of levulinic acid production from aqueous glucose solutions, ChemSusChem, 5 (2012) 1280-1290.

[46] R. Weingarten, W.C. Conner, G.W. Huber, Production of levulinic acid from cellulose by hydrothermal decomposition combined with aqueous phase dehydration with a solid acid catalyst, Energy \& Environmental Science, 5 (2012) 7559-7574.

[47] Y. Yang, C. Hu, M.M. Abu-Omar, Conversion of glucose into furans in the presence of AlCl3 in an ethanol-water solvent system, Bioresource technology, 116 (2012) 190-194.

[48] J.M.R. Gallo, D.M. Alonso, M.A. Mellmer, J.A. Dumesic, Production and upgrading of 5-hydroxymethylfurfural using heterogeneous catalysts and biomass-derived solvents, Green Chemistry, 15 (2013) 85-90.

[49] X. Hu, L. Wu, Y. Wang, Y. Song, D. Mourant, R. Gunawan, M. Gholizadeh, C.Z. Li, Acid-catalyzed conversion of mono- and poly-sugars into platform chemicals: effects of molecular structure of sugar substrate, Bioresource technology, 133 (2013) 469-474.

[50] V.V. Ordomsky, V.L. Sushkevich, J.C. Schouten, J. van der Schaaf, T.A. Nijhuis, Glucose dehydration to 5-hydroxymethylfurfural over phosphate catalysts, Journal of Catalysis, 300 (2013) 37-46. 
[51] N. Shi, Q.Y. Liu, Q. Zhang, T.J. Wang, L.L. Ma, High yield production of 5hydroxymethylfurfural from cellulose by high concentration of sulfates in biphasic system, Green Chemistry, 15 (2013) 1967-1974.

[52] D.M. Alonso, J.Q. Bond, J.A. Dumesic, Catalytic conversion of biomass to biofuels, Green Chemistry, 12 (2010) 1493-1513.

[53] J.D. Holladay, J. Hu, D.L. King, Y. Wang, An overview of hydrogen production technologies, Catalysis Today, 139 (2009) 244-260.

[54] R.M. Navarro, M.A. Pena, J.L. Fierro, Hydrogen production reactions from carbon feedstocks: fossil fuels and biomass, Chemical reviews, 107 (2007) 3952-3991.

[55] R.M. Navarro, M.C. Sanchez-Sanchez, M.C. Alvarez-Galvan, F. del Valle, J.L.G. Fierro, Hydrogen production from renewable sources: biomass and photocatalytic opportunities, Energy \& Environmental Science, 2 (2009) 35-54.

[56] J. Udomsirichakorn, P.A. Salam, Review of hydrogen-enriched gas production from steam gasification of biomass: The prospect of CaO-based chemical looping gasification, Renewable and Sustainable Energy Reviews, 30 (2014) 565-579.

[57] D. Levin, L. Pitt, M. Love, Biohydrogen production: prospects and limitations to practical application, International Journal of Hydrogen Energy, 29 (2004) 173-185.

[58] A. Tanksale, J.N. Beltramini, G.M. Lu, A review of catalytic hydrogen production processes from biomass, Renew Sust Energ Rev, 14 (2010) 166-182.

[59] G.W. Huber, S. Iborra, A. Corma, Synthesis of transportation fuels from biomass: chemistry, catalysts, and engineering, Chemical reviews, 106 (2006) 4044-4098.

[60] D. Dayton, A review of the literature on catalytic biomass tar destruction, in: Milestone Completion Report, National Renewable Energy Laboratory, 2002.

[61] J. Han, H. Kim, The reduction and control technology of tar during biomass gasification/pyrolysis: An overview, Renewable and Sustainable Energy Reviews, 12 (2008) 397-416.

[62] J.M. Encinar, F.J. Beltran, A. Ramiro, Pyrolysis/gasification of agricultural residues by carbon dioxide in the presence of different additives: influence of variables, Fuel Processing Technology, 55 (1998) 219-233.

[63] J. Gil, J. Corella, M.P. Aznar, M.A. Caballero, Biomass gasification in atmospheric and bubbling fluidized bed: Effect of the type of gasifying agent on the product distribution, Biomass and Bioenergy, 17 (1999) 389-403.

[64] D. Sutton, B. Kelleher, J.R.H. Ross, Review of literature on catalysts for biomass gasification, Fuel Processing Technology, 73 (2001) 155-173.

[65] C. Di Blasi, Combustion and gasification rates of lignocellulosic chars, Progress in Energy and Combustion Science, 35 (2009) 121-140. 
[66] Z.L. Liu, H.H. Zhu, Steam Gasification of Coal Char Using Alkali and Alkaline-Earth Metal-Catalysts, Fuel, 65 (1986) 1334-1338.

[67] W.K. Zhu, W.L. Song, W.G. Lin, Catalytic gasification of char from co-pyrolysis of coal and biomass, Fuel Processing Technology, 89 (2008) 890-896.

[68] B.F.M. Kuster, L.M. Tebbens, Analytical proceduce for stuying the dehydration of Dfructose, Carbohydrate Research, 54 (1977) 158-164. 


\title{
Characterisation of humin - the insight to chemical structure \& Reactivity of humin in dry reforming
}

\begin{abstract}
Humin derived from dehydration of D-glucose was used in this study. Solvent fractionation and multiple characterisation techniques (e.g., ATR-IR, HR-SEM, CHNS elemental analyser, solid state ${ }^{13} C N M R$ ) were employed to understand the composition and chemical structure of pristine humin. The influence of dry reforming conditions on humin was investigated using various probe techniques such as TGA coupled with MS, pyrolysis, HR-SEM, Raman spectroscopy and NMR. The results indicated that humin underwent drastically morphological and structural change under heating condition to reach gasification temperature. Humin residue prior reforming stage resembles to bio-char. Chemical structure of humin was proposed from characterisation data (from pristine humin and insight to its structure during heating treatment). Thermal dry reforming was performed at atmospheric condition in the temperature range from 750 to $900{ }^{\circ} \mathrm{C}$ with $\mathrm{CO}_{2}$ partial pressure from 5066 $\mathrm{Pa}$ to $40530 \mathrm{~Pa}$. Due to the low reactivity of humin in thermal dry reforming, catalyst is required to accelerate the reforming reaction.
\end{abstract}




\subsection{Introduction}

The depletion of fossil raw materials, especially crude oil and the increasing demand for fuel, energy and chemicals as a result of improved living standards, have generated interest in alternative, sustainable feedstocks [1-3]. Lignocellulosic biomass is considered as one of the potential renewable feedstocks $[1,2,4-6]$. Carbohydrates, which include cellulose and hemicellulose, are the largest constituents, comprising approximately $70-80$ wt.\% of lignocellulose. The conversion of carbohydrates to chemical platform molecules is considered as an important part of the bio-refinery concept [7, 8]. Such conversions require hydrolysis de-polymerization of polysaccharides for production of sugars such as xylose and hexose from hemicellulose and cellulose, respectively. According to the report of the U.S. Department of Energy in 2004 [9], three of the twelve top value added chemical building blocks, namely 5-hydroxymethyl furfural (HMF), furfural (FF) and levulinic acid (LA), are produced by the dehydration of sugar using acid catalysts. These reactions are usually performed in the aqueous phase.

The dehydration of sugars often leads to the formation of waste by-products. The most significant among these are the insoluble disperse polymeric residues, generally called humin, humins, humin-like substances or sometimes simply char or coke [10-13]. The formation of humin is reported in most papers during the synthesis of HMF, LA or FF from (poly)saccharides. The yield of humin is influenced by process parameters such as the type of sugar substrate, time, temperature and type of acid catalyst. For example, in an aqueous rich medium, humin yields vary from $5.3-27.5$ wt.\% during the formation of FF from xylose using $\mathrm{HCl}$ or the solid acid $\mathrm{Yb}(\mathrm{OTf})_{3}$ as catalyst [13]. In the case of cellulose conversion to LA, humin yields range from 25 - 45 wt. $\%$ [10-12]. In the case of HMF production even $10-$ 50 wt.\% of sugar substrates can be converted into humin [14]. Humin is thus a major waste fraction during sugar conversion.

Efforts have been made to suppress the formation of humin for example, by co-feeding alcohol to stabilize HMF by esterification and thus prevent its further conversion to humin. However, the yield of humin is still 14-22 wt.\% [15]. Despite intensive investigation on the various conversion routes of polysaccharides, understanding of the pathway of humin formation is poor. Furthermore, a clear description of the nature of humin itself is lacking.

Although humin as a by-product is known for a long time, its use as feedstock is limited to combustion. Further, its chemical structure and properties is not well understood. Generally, it is suggested that humin is a heterogeneous polymeric by-product from carbohydrate conversion which result from the condensation reactions between the 
carbohydrate (e.g., glucose, fructose) and its intermediates formed during transformation to HMF/FF/LA. Since humin contains C ca. 60 wt.\% [16, 17], it can be used as feedstock for production of synthesis gas or hydrogen via gasification. Hydrogen is omnipresent in biorefinery [1], such as conversion of LA to GVL, hydrogenation of glucose to sorbitol. However, minimising the use of external $\mathrm{H}_{2}$ for making biofuels/green chemicals is mandatory [1]. From this point of view, efficient conversion of humin to $\mathrm{H}_{2}$ or syngas $(\mathrm{CO}+$ $\mathrm{H}_{2}$ ) is conceptually attractive. Producing $\mathrm{H}_{2}$ /syngas from humin which is considered as waste residue would allow complete use of feedstock carbon in the sugar conversion processes, enhancing the E (environmental) factor of end targeted product. Therefore, in this chapter, we discuss: (i) the characteristics of humin formed during sugar conversion; (ii) changes that take place during heating to gasification temperature for dry reforming; and (iii) kinetics of dry reforming of humin.

\subsection{Experimental}

All chemicals used in this study were analytical grade, purchased from Sigma-Aldrich and used without further purification.

\subsubsection{Humin preparation and purification}

Humin was prepared as following. A mixture of $500 \mathrm{ml}$ glucose $1 \mathrm{M}$ and sulphuric acid $0.01 \mathrm{M}$ were placed in quartz insert of $1 \mathrm{~L}$ Büchi stirred autoclave. The mixture was flushed with helium at room temperature to remove air. It was then heated to $180{ }^{\circ} \mathrm{C}$ and kept at that temperature for $6 \mathrm{~h}$ with stirring rate $500 \mathrm{rpm}$. After that the reactor was cooled down to room temperature (RT). Insoluble products were filtered with a Brüchner funnel and washed with 3 $\mathrm{L}$ of de-mineralised water. The solid humins were then dried at $80{ }^{\circ} \mathrm{C}$ for $24 \mathrm{~h}$ and then ground to granular powder $(<300 \mu \mathrm{m})$. Humins after this step were denoted as HG1. HG1 was then purified using Soxhlet extraction with water for $24 \mathrm{~h}$. After that, the solid was dried in vacuum oven at $80^{\circ} \mathrm{C}$ for $24 \mathrm{~h}$ and denoted as $\mathrm{HG} 2$.

Solubility of humin in various solvents (e.g., water, acetone etc.) was determined using standard analytical methods applied for wood and pulp, approved by Technical Association of the Pulp and Paper Industry (TAPPI). Water solubility of humin was performed and estimated using "TAPPI T207 cm-99 Standard”. Acetone extractives of humin were carried out according to "TAPPI T204 cm-97 Standard". One per cent sodium hydroxide solubility of humin was determined using “TAPPI T212 om-02 Standard”. Residues of humin after the extraction in hot water, acetone and $\mathrm{NaOH} 1$ wt.\% are denoted as HG1-W, HG1-Ac, HG1-NaOH $1 \%$, respectively. HG1-W was further extracted in acetone and tetra hydro furan 
(THF) using method described in the "TAPPI T204 cm 97". Short description of these methods can be found in the Appendix section. The solvents containing extractives were later analysed by LDI-TOF and ESI mass spectrometric techniques.

Samples for elemental analysis and Nuclear Magnetic Resonance (NMR) experiments were prepared by heating $c a .1 \mathrm{~g}$ humin in a furnace under $100 \mathrm{ml} \cdot \mathrm{min}^{-1}$ flow of $40 \mathrm{vol} . \%$ $\mathrm{CO}_{2}$ balanced with $\mathrm{N}_{2}$. Furnace temperature was increased at the rate $10{ }^{\circ} \mathrm{C} \cdot \mathrm{min}^{-1}$, kept constant at the desired temperatures for $0.2 \mathrm{~h}$, and then cooled down to room temperature.

\subsubsection{Characterisation}

Elemental composition was determined with a Perkin-Elmer elemental analyser (Thermo Scientific Flash 2000). The analyser was equipped with a two-reactive-bed-column and calibrated with acetanilide. Carbon, hydrogen and nitrogen were estimated based on the amount of water, $\mathrm{CO}_{2}$ and $\mathrm{N}_{2}$ from the chromatogram. Oxygen content was calculated as the remaining part.

Morphology of humins was analysed by High Resolution Scanning Electron Microscopy (HR-SEM) using HR-SEM Zeiss 1550.

Specific area was determined from t-plot in BET method with a Micromeritics Tristar instrument. Humin samples pre-heated at various temperatures $\left(300-700{ }^{\circ} \mathrm{C}\right)$ and fresh humin were degassed at $300^{\circ} \mathrm{C}$ and $150{ }^{\circ} \mathrm{C}$, respectively for $24 \mathrm{~h}$ prior to the analysis.

For ATR-IR analysis, acetone soluble fraction of pristine humin or solid humin were deposited or placed directly on a ZnSe crystal. The crystal with samples was dried in vacuum oven for 30 minutes at $50{ }^{\circ} \mathrm{C}$ to remove solvent and minimise moisture between humin particles. ATR-IR analysis was acquired with a Bruker Tensor 27 infrared spectrometer equipped with a MCT detector. All ATR-IR spectra were recorded at $c a .21^{\circ} \mathrm{C}$ by averaging of 128 scans with resolution of $4 \mathrm{~cm}^{-1}$.

Qualitative analysis of components in the effluents after extraction in water and $\mathrm{NaOH}$ was performed with a mass spectrometry detector (MSD) (SL/G1956B, Agilent) equipped with an electro-spray ionisation (ESI) liquid-phase interface (G1948A, Agilent). The effluents were sent to the ESI chamber by a syringe pump with flow-rate $0.5 \mathrm{ml} \cdot \mathrm{min}^{-1}$. ESI was operated in positive mode with fragmentation voltage of $200 \mathrm{~V}$, drying gas temperature $350{ }^{\circ} \mathrm{C}$.

Extractives of humin in acetone were dissolved in THF $(0.1 \mathrm{~g} / 10 \mathrm{ml} \mathrm{THF})$ for gel permeation chromatography (GPC) analysis. The GPC data was obtained using a 
GPC system of Agilent Technologies 1200 series equipped with an reflective index detector, calibrated with polystyrene standards (molecular masses between 162 and 29510 Dalton).

For Laser desorption ionisation time of flight MS (LDI TOF MS), humin was dispersed in water using ultra-sonication bath. $2 \mu$ of the mixture was pipetted onto the stainless steel MS plate. The mass spectra were recorded using a Waters SYNAPT HDMS MALDI-TOF mass spectrometer operated in positive ion mode. Poly-ethylene glycol standards were used for calibration.

Carbon structure of humin was identified by a Bruker Senterra Raman spectrometer with laser wavelength $532 \mathrm{~cm}^{-1}$. Humin particles are black bodies and can be heated up easily under the laser beam, which can cause structural influence or damage to the material. To diminish this thermal emission, samples were mixed with spectroscopic grade $\mathrm{KBr}$ and ground with mortar and pestle. The powder mixtures of $0.5 \mathrm{wt} . \%$ humin in $\mathrm{KBr}$ were then pelleted. Laser power of $10 \mathrm{~mW}$, contact time $1 \mathrm{~s}$ was used. Each Raman spectrum represents the average of 50 scans with spectral resolution of $4 \mathrm{~cm}^{-1}$.

Solid state ${ }^{13} \mathrm{C}$ Nuclear Magnetic Resonance spectra of humin were acquired on a 14.1 T Varian VNMRS system at Magic Angle Spinning (MAS) frequency of 20 $\mathrm{kHz}$ using $3.2 \mathrm{~mm}$ MAS probe. Contact time of $1000 \mu \mathrm{s}$ and $50 \mu \mathrm{s}$ was used for cross polarization (CP) and single pulse (SP) experiments, respectively. The spectra were referenced to adamantane.

Pyrolysis experiments were performed as described elsewhere [18]. $\mathrm{CO}_{2} / \mathrm{Ar}$ mixture $\left(\mathrm{CO}_{2} 40\right.$ vol.\%) was used to mimic the dry reforming experiment. For the experiment to identify volatiles as function of temperature, the furnace was heated from RT to $400{ }^{\circ} \mathrm{C}$ in less than a minute, kept at that temperature for 15 minutes before it was raised to the next temperature (e.g., 500, 600, and $700{ }^{\circ} \mathrm{C}$ ). The condensable products were collected during each step. In a separate experiment one sample was heated directly to $700{ }^{\circ} \mathrm{C}$ (heating rate $c a .925{ }^{\circ} \mathrm{C} \cdot \mathrm{min}^{-1}$ ). The condensable products formed during pyrolysis experiments were diluted with acetone and analysed by an Agilent 7890AGC coupled with 5975C Mass Spec. The identification was based on NIST (National Institute of Standards) 2008 library.

\subsubsection{Thermo gravimetric analysis and dry reforming experiments}


TGA experiments were performed using a Mettler Toledo analyser (TGA/SDTA/851e) with samples of $2-3 \mathrm{mg}$ initial weight, $100 \mathrm{ml} . \mathrm{min}^{-1}$ flow rate of $\mathrm{CO}_{2} /$ Argon mixture $\left(\mathrm{CO}_{2} 5-40\right.$ vol.\%). The initial weight was small enough to avoid mass transfer limitations (experiments show conversion rate is independent of sample mass below $5 \mathrm{mg}$ ). Typically, samples were first dried in situ at $105{ }^{\circ} \mathrm{C}$ (heating rate from RT of $10^{\circ} \mathrm{C} \cdot \mathrm{min}^{-1}$ ) for 1 hour to remove any physically adsorbed water; then they were heated to the desired temperatures with the same rate and kept at those temperatures for the required time ( $4-6$ hours). The exhaust gas from TGA was analysed by an on-line quadrupole mass spectrometry (QMS).

All conversion values used in this study are cumulative and calculated as following:

$$
\begin{aligned}
& \text { Conversion }\left(\mathrm{X}_{\mathrm{i}}\right)=\frac{\mathrm{m}_{0}-\mathrm{m}_{\mathrm{i}}}{\mathrm{m}_{0}} \quad(\mathrm{w} / \mathrm{w}) \\
& \text { Residue weight }=\frac{\mathrm{m}_{\mathrm{i}}}{\mathrm{m}_{0}} \quad(\mathrm{w} / \mathrm{w}) \\
& \text { Gasification rate }=\frac{\delta \mathrm{X}_{\mathrm{i}}}{\delta \mathrm{t}}\left(\mathrm{min}^{-1}\right)
\end{aligned}
$$

Where: $\mathrm{m}_{0}, \mathrm{~m}_{\mathrm{i}}$ are mass of humin after in situ drying at $105^{\circ} \mathrm{C}$ for 1 hour and at the interest point, respectively; $\mathrm{X}_{\mathrm{i}}$ is conversion at that point.

\subsection{Results and discussion}

\subsubsection{Pristine humin}

HR-SEM images of the pristine humin sample used in this study are shown in Figure 2.1- A-B. It can be seen from Figure 2.1-A that humin comprises of dark (brown), solid, sphere-shaped agglomerates with wide size distribution $(1-20 \mu \mathrm{m})$. This size range is much wider than that reported elsewhere $[16,19](5-10 \mu \mathrm{m})$ for humin obtained from HMF, glucose or cellulose. In our sample, particles below $3 \mu \mathrm{m}$ have a more defined spherical shape while the larger ones look like smaller spheres fused together. The cross section image (not shown) of these particles indicates no clear boundary or interface between the smaller spheres. At higher magnification (Figure. 2.1-B) smooth surface and a dense core structure of the humin particles can be seen. This is confirmed by nitrogen adsorption at liquid nitrogen temperature; the specific area of this pristine humin is negligible. 

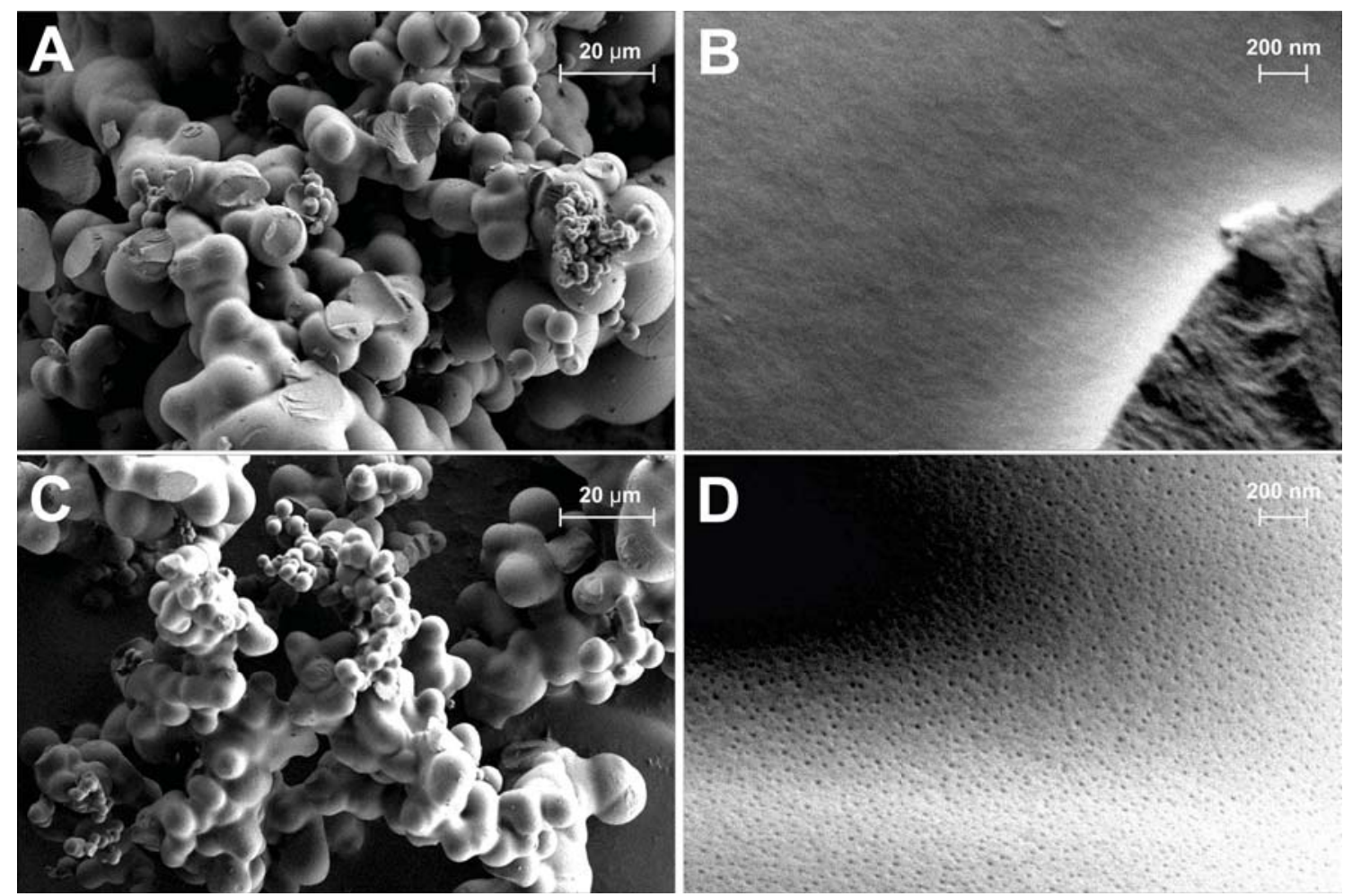

Figure 2.1. HR-SEM images of HG1 (A, B) and HG2 (C, D). B, D - HR SEM images of surface of $\mathrm{HG} 1$ and $\mathrm{HG} 2$ respectively

Generally, it is suggested that humin is formed by condensation of intermediates formed during dehydration of sugar. Besides, all components which are part of the reaction sequence can also be embedded in the humin matrix. For example, Baccile [20] reported that about $15 \mathrm{wt} . \%$ carbon exists in the form of levulinic acid entrapped in carbon spheres. It should be noted that the hydrothermal carbon spheres were synthesised in a similar method for making humin - except that the dehydration reactions are catalysed by the acid in situ generated. Hence, it could be possible to extract these embedded components using solvents such as water or acetone. It is observed that extraction solvents changed to brown colour after refluxing with humin. The extractable fractions in various solvents and their elemental composition of the residue after extraction are shown in Table 2.1. Only 7.5 wt.\% of humin dissolves in hot water $\left(\sim 95^{\circ} \mathrm{C}\right)$. Acetone or $\mathrm{NaOH} 1 \mathrm{wt} \% \%$ in water is more effective. While water can extract hydrophilic, light, water soluble components such as HMF, LA, and acetone might be capable of removing more polymerised oligomers which can be more hydrophobic. $\mathrm{NaOH}$ can also affect the hydrolysis of oligomers or humin. GC-MS analysis of the solution after Soxhlet extraction of pristine humin (HG1) in acetone confirmed the presence of LA, HMF, 5-methyl furfural, furfural, 2-acetyl furan which 
are formed during the dehydration of glucose [21]. These identified compounds comprise $c a .90 \%$ peak area in the gas chromatogram (not shown). However, it should be noted that the GC-MS can only analyse the volatile fraction of the extraction solution (boiling point below $250{ }^{\circ} \mathrm{C}$ ). After Soxhlet extraction $(24 \mathrm{~h}$ for water and 8 hour for acetone), the solvent in contact with solid humin became colourless and did not contain any extractable as seen by GC-MS. Thus, it can be assumed that the extraction was completed and all of the embedded components were removed. HRSEM images of humin after Soxhlet extraction for $24 \mathrm{~h}$ in water is shown in Figure 1C-D. There is no clear indication of change in particle size (Figure 1-C). However shallow pores on the surface of humin after the extraction can be seen (Figure 1-D). This might be the result of removal of the oligomers or precursors of humin. This is in agreement with the growth mechanism of humin or carbon spheres proposed by Yao et al. [22] for glucose, where the spheres grow by condensation at the external surface, also implying the presence of oligomers on the surface.

Table 2.1. Elemental composition of humin and humin fractions

\begin{tabular}{lcccc}
\hline Sample & C (wt.\%) & H (wt.\%) & O (wt.\%) & Dissolved Fraction \\
\hline HG1 & $66.3 \pm 1$ & 4.4 & 29.3 & 0 \\
HG1-W & 66.3 & 4.2 & 29.5 & $\sim 7.5$ wt.\% \\
HG2 & 66.1 & 4.4 & 29.5 & n.a. \\
HG1-Ac & 67.9 & 4.3 & 27.8 & $\sim 11$ wt. $\%$ \\
HG1-NaOH 1 wt. $\%$ & 66.3 & 4.2 & 29.0 & $\sim 15.8$ wt.\% \\
HG1-W-Ac & 65.7 & 4.2 & 30.1 & n.a. \\
HG1-W-Ac-F & 67.9 & 4.8 & 27.2 & n.a. \\
Acetone soluble & 63.2 & 5.4 & 31.4 & \\
\hline
\end{tabular}

HG1-W-Ac: humin residue after extractions in water then in acetone, HG1-W-Ac-F: is residue of Soxhlet extraction of HG1-W-Ac in THF; n.a-not available

Table 2.1 also shows the elemental composition of humin and its residues after the purification. In addition to $\mathrm{C}, \mathrm{H}, \mathrm{O}$ contents, small amounts of sulphur $(0-c a$. $1200 \mathrm{ppm}$ ) were also found in some batches of humin. This S content can result from the sulfonation reaction between sulphuric acid and humin or sugar substrates during the dehydration. The elemental composition of pristine humin in this research is similar to those reported by others $[16,19]$. Variations in the carbon content of humin samples 
are the result of different extent of dehydration and depend on experimental conditions [23]. Within our experiments, only very minor changes in elemental composition were observed (Table 2.1) for humin and its residues after various extraction steps in different solvents. The fraction extracted with acetone still contains low mass sugar inter-mediates such as HMF and LA.

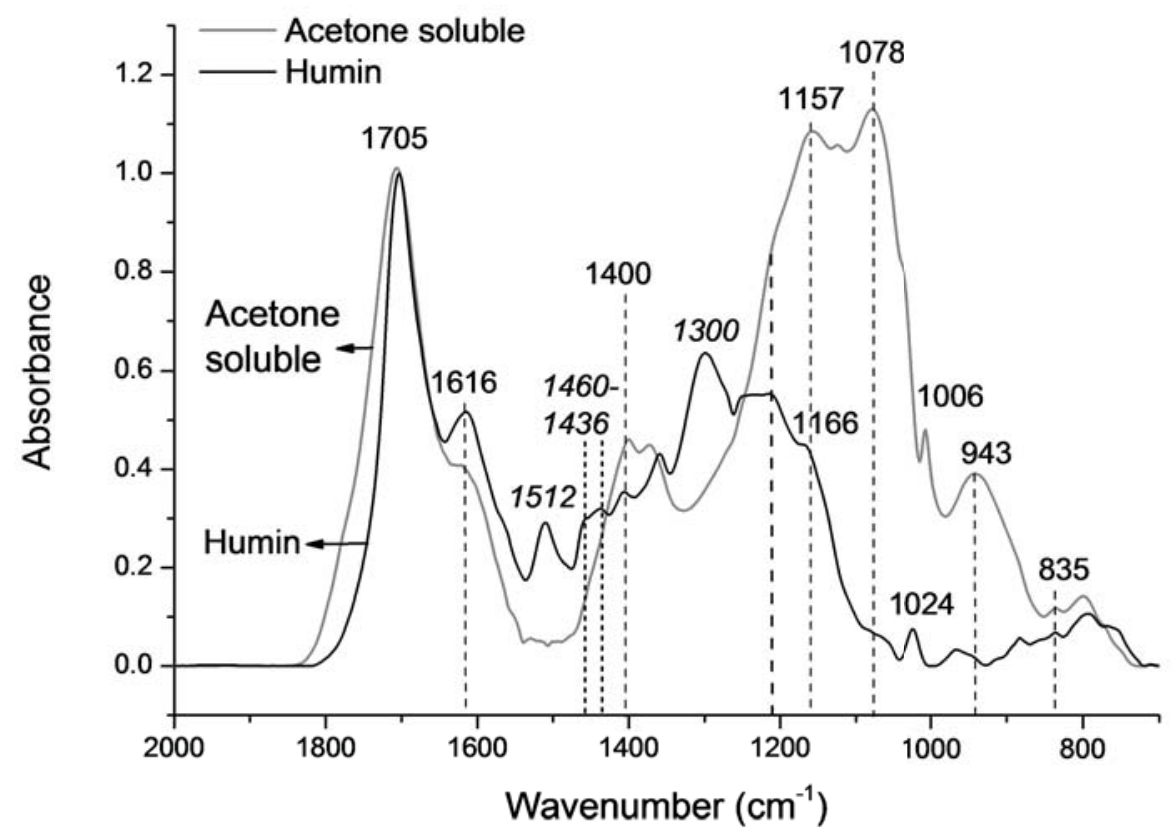

Figure 2.2. ATR-IR of humin and acetone soluble fraction

GPC analysis of the acetone soluble fraction provide a number-averagemolecular mass of 302 Dalton and $90 \%$ of the sample eluting from the GPC column has mass below 2000 Dalton (A.2.1, Appendix). Lower masses include (i) 110 Dalton which can be acetyl furan or methyl furfural, (ii) 138 Dalton, corresponding to the formula $\mathrm{C}_{7} \mathrm{H}_{6} \mathrm{O}_{3}$, and (iii) 252 Dalton which can be attributed to acetal of 2-HMF. The higher masses might be from the oligomer by-products in the de-hydration of glucose or humin segments which can be dissolved in acetone or the recombination/ condensation of the low mass molecules (HMF, LA, FF, 2-acetyl furan etc.). The higher mass molecules can be considered as humin precursor/fragments. MS analysis of soluble humin in $\mathrm{NaOH} \mathrm{1 \% ,} \mathrm{water} \mathrm{(by} \mathrm{ESI-MS,} \mathrm{Figure} \mathrm{A.2.3)} \mathrm{as} \mathrm{well} \mathrm{as} \mathrm{solid}$ humin (LDI-TOF MS, Figure A.2.4) shows a significant peak of 301 Dalton. In addition, set of peaks with 300 Dalton difference were observed in MS spectra (Figure A.2.4, Appendix section). From the relative ratio of the peaks $301+1$ and 301 Dalton, the number of carbon in the molecule is estimated as 17. Regarding the elemental 
composition, the mass 301 can be assigned to the chemical formula of $\mathrm{C}_{17} \mathrm{H}_{16} \mathrm{O}_{5}$. All resolved masses from MS analysis are below 3000 Dalton.

The ATR-IR spectra of pristine humin (HG1) and the fraction that is soluble in acetone are displayed in Figure 2.2. Peaks at $1705 \mathrm{~cm}^{-1}$, corresponding to $\mathrm{C}=\mathrm{O}$ asymmetric stretching typical for carbonyls, and $1616,1400 \mathrm{~cm}^{-1}$ to 2-substituted furans, are as expected present in samples. Peak at $1512 \mathrm{~cm}^{-1}$, typically corresponds to poly-substituted furans and since it is present only in humin sample, it may be due to furan structure present in the framework. The peaks at 1436 and $1460 \mathrm{~cm}^{-1}$ can be assigned to $\mathrm{CH}_{2}$ deformation vibrations in aliphatic chains. The shift of peak at 1460 to lower range (i.e., $1436 \mathrm{~cm}^{-1}$ ) is due to being adjacent to double bonds or carbonyl groups. 1024 and $1300 \mathrm{~cm}^{-1}$ in humin corresponds to $\mathrm{C}=\mathrm{C}$ stretching and $\mathrm{C}-\mathrm{H}$ rocking, respectively, in olefinic groups. Strong peaks at 1078 and $1157 \mathrm{~cm}^{-1}$ corresponding to C-O stretching in alcohols is seen in the extracted sample [24].

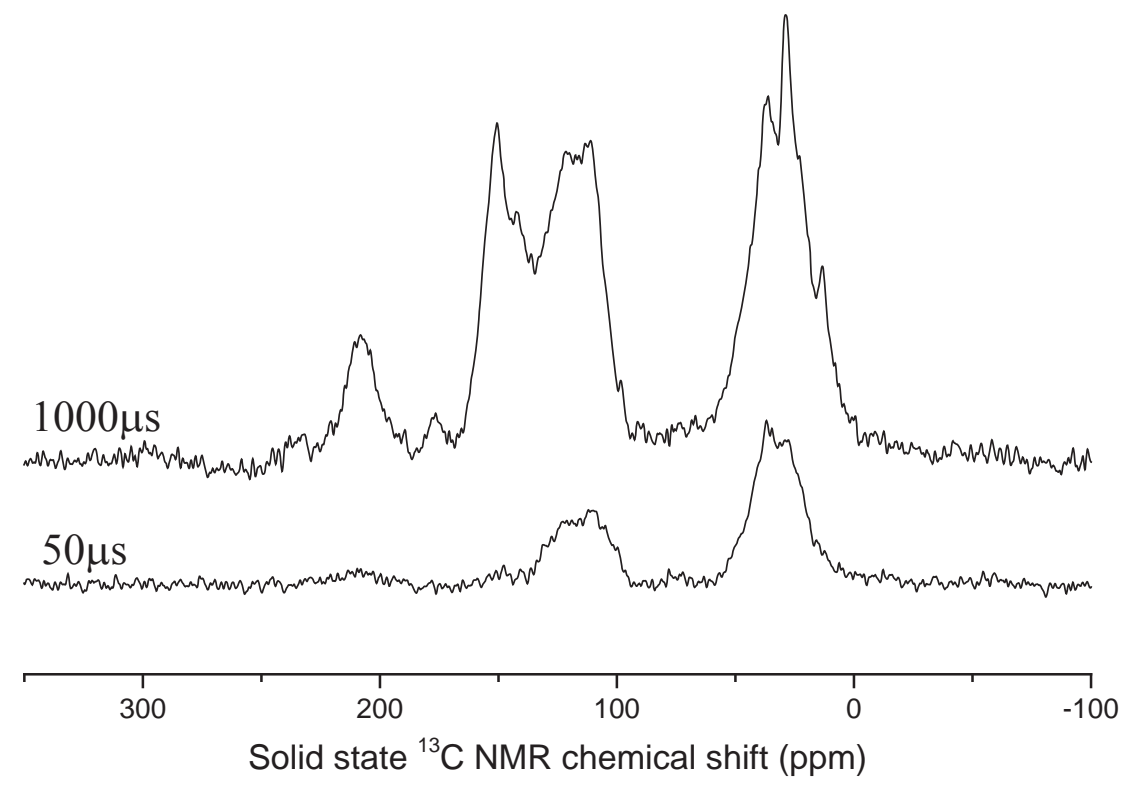

Figure 2.3. Solid state ${ }^{13} \mathrm{C}-\mathrm{MAS}$ NMR of pristine humin (HG1) with long contact time (cross polarisation mode) and short contact time (single pulse mode)

Figure 2.3 shows solid state ${ }^{13} \mathrm{C}$ NMR spectra of humin recorded at long contact time $(1000 \mu \mathrm{s})$ using cross polarization mode and short contact time $(50 \mu \mathrm{s})$ with single pulse mode. The spectrum from short contact time analysis mainly shows functional groups which contain proton $(\mathrm{H})$. By comparing spectra between these two NMR modes, it is possible to identify the functional groups which have the same value of chemical shift (e.g., ketone vs. aldehyde or carboxylic acid $v s$. ester). Therefore, the band $210 \mathrm{ppm}$ corresponds to carbon in carboxylic and not in ester group, while 178 ppm represents ketone and not aldehyde [20]. The band from $0-50 \mathrm{ppm}$ is assigned to aliphatic groups $\left(\mathrm{CH}_{\mathrm{x}}\right)$. The main band between 100 
and 150 corresponds to $\mathrm{sp}^{2}$ carbon. According to Baccile et al. [20] and Falcao et al. [25], bands in this region comprise three types of functional groups: (i) furanic carbon at alpha position (150 ppm), (ii) furanic $\mathrm{C}$ at beta position (110 ppm) and (iii) $\mathrm{sp}^{2}$ hybridised aromatic carbon (127 ppm). It can thus be concluded that humin framework mainly consists of furanic segments with aliphatic linkages decorated by carboxylic and ketone groups.

\subsubsection{Changes to humin prior to gasification}
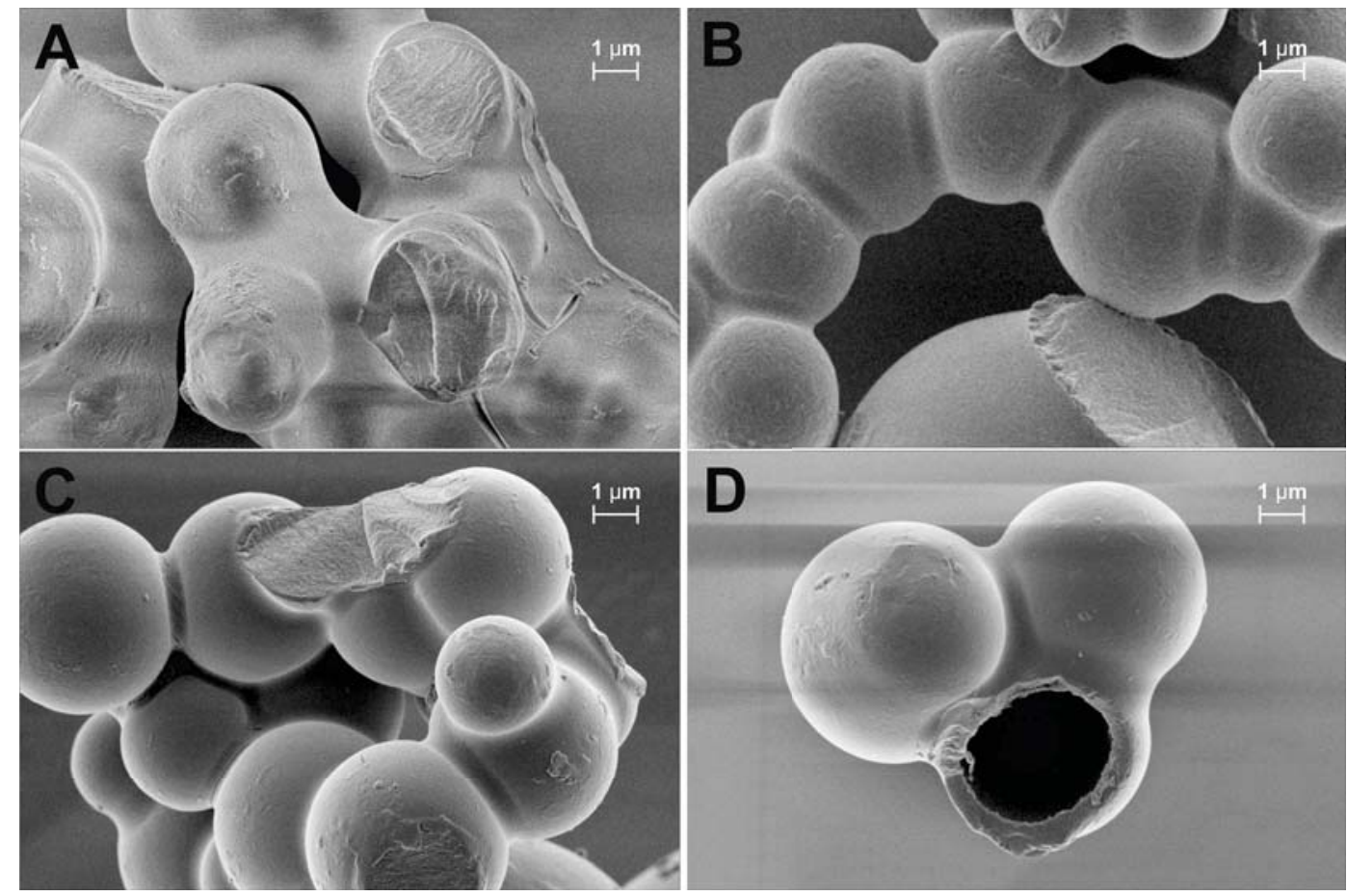

Figure 2.4. $\mathrm{HR}-\mathrm{SEM}$ of humin (HG1) preheated in $\mathrm{CO}_{2}$ at various temperatures: $\mathrm{A}-$ $400{ }^{\circ} \mathrm{C}, \mathrm{B}-500{ }^{\circ} \mathrm{C}, \mathrm{C}-600{ }^{\circ} \mathrm{C}, \mathrm{D}-700{ }^{\circ} \mathrm{C}$

Gasification of humin requires high temperatures, typically $700-900{ }^{\circ} \mathrm{C}$. Since humin is made up of an organic matrix that is unstable during heating, it can be expected to undergo changes and the residue that is gasified can be different from the pristine sample at room temperature. Therefore, understanding any changes that occur is very important. Figure 2.4 shows HR-SEM photographs of humin sample preheated to various temperatures in $\mathrm{CO}_{2}$. There is no clear indication of any change in particle size after heat treatment even up to $700{ }^{\circ} \mathrm{C}$. However, changes in morphology and surface texture are observed. The surface of humin at $400{ }^{\circ} \mathrm{C}$ appears to be swollen and the boundary between particles shows neck formation. At $500{ }^{\circ} \mathrm{C}$, spherical shaped particles are clearer to see and the dense structure is maintained in agreement with the similar low (below detection limits) surface areas measured by $\mathrm{N}_{2}$ adsorption at liquid 
nitrogen temperature. At 600 and 700 ${ }^{\circ} \mathrm{C}$, sample becomes very porous with specific area of 463 and 447 $\mathrm{m}^{2} / \mathrm{g}$, respectively. This can be the result of loss of part of humin, e.g., escape of molecules trapped in the humin matrix, as discussed earlier. These are discussed in more detail in the following section. The most surprising result is the appearance of hollow structures (Figure 4-D) in humin particles at $700{ }^{\circ} \mathrm{C}$. This phenomenon did not occur in the

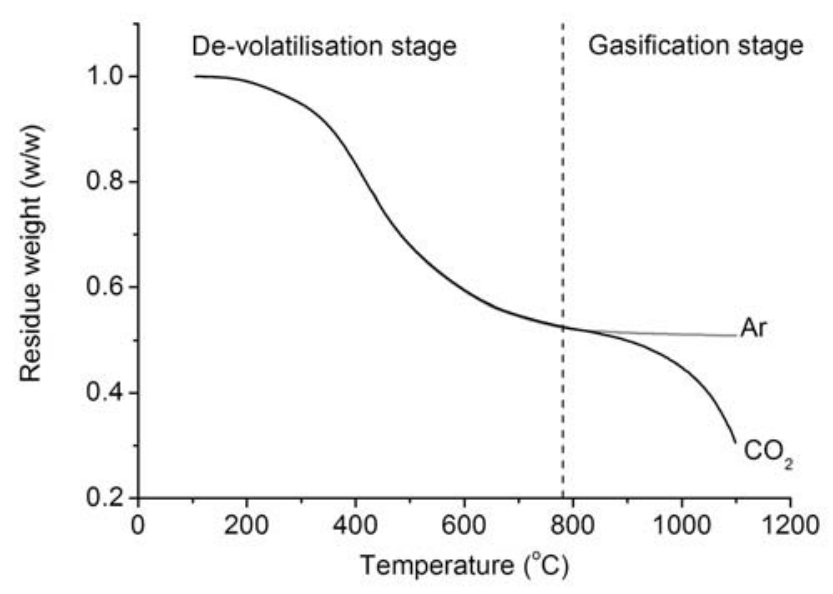

Figure 2.5. TGA analysis of humin in inert (Ar) and 40 vol. $\% \mathrm{CO}_{2}$ atmospheres. Ramp $=10$ ${ }^{\circ} \mathrm{C} \cdot \mathrm{min}^{-1}$ case of heating in inert gas $\left(\mathrm{N}_{2}\right)$. The unique hollow structure could result from faster dry reforming reactions of the materials at the core of humin particles, which is more reactive than those at the shell. This indicates an asymmetric composition across the radius of humin particle. The degree of carbonisation and condensation of the insoluble polymer at the core layer might be lower than that of the shell, which had more contact with acidic medium of the sugar dehydration process. Surprisingly, we did not see this in the case of steam (ca. 2 vol.\% steam/ $\mathrm{N}_{2}$ ) [26]. This probably is because $\mathrm{CO}_{2}$ is a very mild oxidant and less reactive than steam, in the latter case gasification is possible and occurs everywhere (see Chapter 3).

HR-SEM analysis visualised the influence of thermal treatment on humin. Other characterisation techniques such as TGA, pyrolysis were employed to gain further insight into the influence of pre-heating on humin. The thermal gravimetric analysis of humin under inert and reactive gas atmospheres is depicted in Figure 2.5. In both $\mathrm{CO}_{2}$ and Ar, continuous weight loss occurs from $105{ }^{\circ} \mathrm{C}$ to $700{ }^{\circ} \mathrm{C}$, followed by a stable period up to $c a .800^{\circ} \mathrm{C}$. While in Ar the weight loss levels off at a value of $c a .45$ wt. \%, in $\mathrm{CO}_{2}$ the rate of weight loss increases again above $800{ }^{\circ} \mathrm{C}$ and continues rising until $1100{ }^{\circ} \mathrm{C}$. The weight loss below $800{ }^{\circ} \mathrm{C}$ can be attributed to thermal devolatilisation since no clear difference between two curves (performed in reactive gas $\left(\mathrm{CO}_{2}\right.$, dry reforming) versus inert $\left.\mathrm{Ar}\right)$. The weight loss in $\mathrm{CO}_{2}$ atmosphere at higher temperatures results from dry reforming reactions of humin residue. However, even at $1100{ }^{\circ} \mathrm{C}$, final weight loss of only $70 \mathrm{wt} \%$ is achieved implying incomplete conversion and low reactivity of part of the humin residue. 


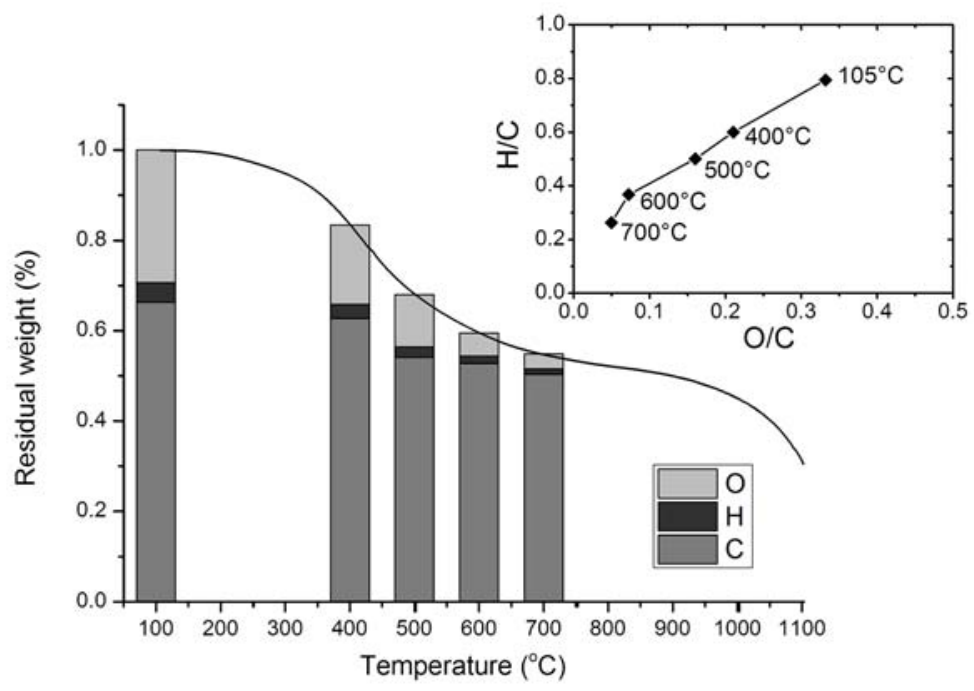

Figure 2.6. Elemental composition of humin residues preheated in $\mathrm{CO}_{2}$ at 400, 500, 600, 700 ${ }^{\circ} \mathrm{C}$ (Inset: Van Krevelen diagram of corresponding humin residues)

The elemental composition of humin as a function of temperature (prior to $\mathrm{CO}_{2}$ reforming temperature) is depicted in Figure 2.6. The inset graph illustrates the Van Krevelen diagram of these intermediate humin residues (the figure presents the pretreatment temperature of that corresponding residue). It reveals the continuous deoxygenation occurring when humin is heated. Loss of oxygen and change in elemental composition is caused by the release of volatile products as well as decomposition of reactive functionalities in its structure to form organic volatiles and gas (e.g., dehydration, decarboxylation, decarbonylation). Humin heated to $700{ }^{\circ} \mathrm{C}$, close to the onset of reforming, contains 92 wt.\% carbon. And the corresponding changes in $\mathrm{H} / \mathrm{C}$ ratios of the samples indicate more and more aromatisation of humin residue as the result of heating. Similar Van Krevelen diagrams were reported for pyrolysis char from pectin [27], and glucose [28].

The online analysis of the exhaust gas released during the TGA experiment showed that the products belong to two groups: (i) permanent gases (e.g., $\mathrm{H}_{2} \mathrm{O}, \mathrm{CO}_{2}$, and $\mathrm{H}_{2}$ ) and (ii) organic volatiles. The former was monitored by QMS (Figure 2.7) while the organics were monitored in a separate experiment, discussed later. The formation of gas products in both thermal decomposition (Figure 2.7-A) and in $\mathrm{CO}_{2}$ reforming (Figure 2.7-B) show similar trends. The signal for $\mathrm{H}_{2} \mathrm{O}$ has 2 peaks at $c a$. $450{ }^{\circ} \mathrm{C}$ and $c a .780{ }^{\circ} \mathrm{C}$. The first peak can be attributed to dehydration of sugar derivatives while the second one might correspond to dehydration or condensation of phenols or aromatic aldehydes. $\mathrm{CO}_{2}$ in the exhaust gas, as result of decarboxylation of 
carboxylic groups in humin structure, peaks at $c a .390{ }^{\circ} \mathrm{C}$ or $396{ }^{\circ} \mathrm{C}$ in inert - Ar or in rich $\mathrm{CO}_{2}$ atmosphere, respectively. The signal of $\mathrm{CO}$ reaches to highest point at $c a .410$ ${ }^{\circ} \mathrm{C}$ in $\mathrm{CO}_{2}$ atmosphere, then levels off from $550{ }^{\circ} \mathrm{C}$ till $800^{\circ} \mathrm{C}$ and rises rapidly above $800{ }^{\circ} \mathrm{C}$. The first peak of $\mathrm{CO}$ is due to de-carbonylation of ketone groups in humin while the rise at elevated temperature range corresponds to the dry reforming reactions. Both de-carboxylation and de-carbonylation not only lead to decrease of O content but also cause loss of $\mathrm{C}$ to gas phase. From Figure 2.6, it can be seen that most of $\mathrm{C}$ loss occurred between 400 and $500{ }^{\circ} \mathrm{C}$. There is no corresponding evolution of $\mathrm{CO}_{\mathrm{x}}$ (Figure 2.7-A or B) in this temperature range, thus the loss in Figure 2.6 does not match with the trend of $\mathrm{CO}$ and $\mathrm{CO}_{2}$ evolution in dry reforming atmosphere and might be attributed to other vapour products (e.g., organic volatiles). The presence of $\mathrm{H}_{2}$ was also detected in the exhaust stream from the TGA furnace. Dehydrogenation takes place above $600{ }^{\circ} \mathrm{C}$ and reaches its peak at $c a .750{ }^{\circ} \mathrm{C}$. This might contributes to the sharp slope in Van Krevelen plot between $600-700{ }^{\circ} \mathrm{C}$, besides some possible aromatisation reactions.

In order to identify the chemical functionalities of the volatile products, fast pyrolysis technique using rapid IR heating was employed [18]. This technique provides an extremely high heating rate, short retention time of the vapour in the heated zone therefore, minimising secondary reactions of the volatiles. To avoid the influence of sugar derivatives entrapped in the pristine humin, the humin purified in water for $24 \mathrm{~h}$ (HG2) was used for this experiment. The composition of organic volatiles, based on GC-MS area percentage analysis, as function of treatment temperature is illustrated in Figure 2.8. Each bar on the graph represents the composition of the volatiles which release from purified humin - HG2 (no sugar derivatives left
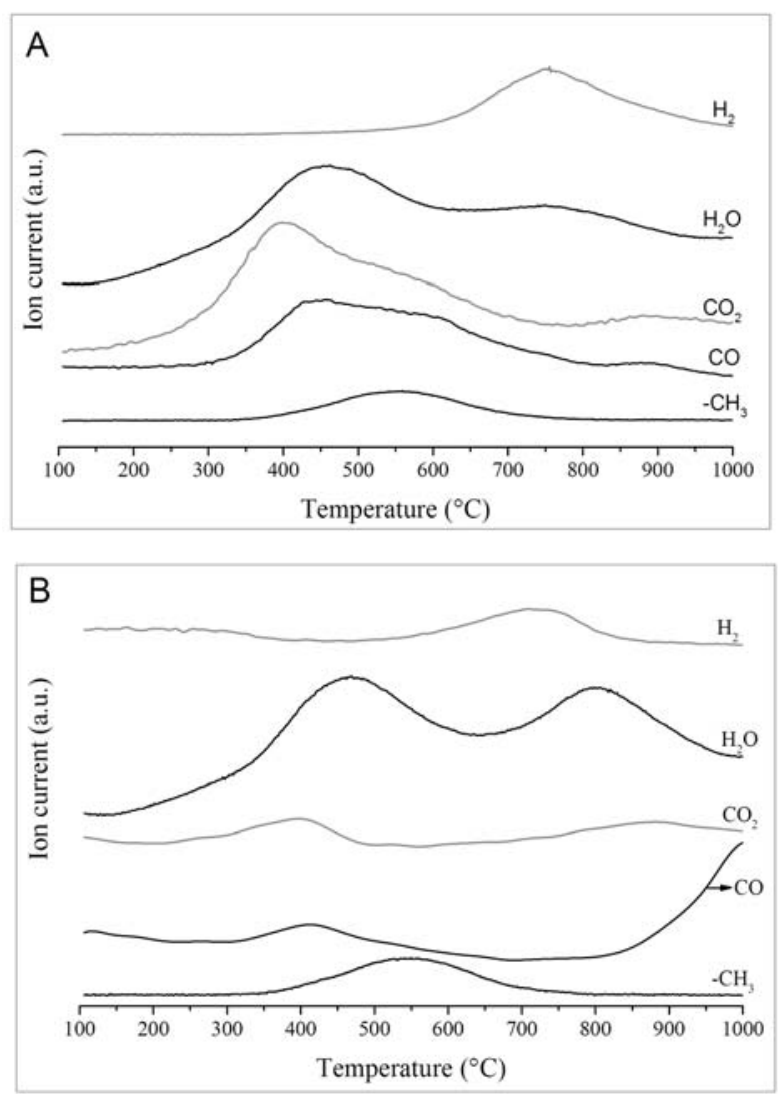

Figure 2.7. Evolution of gas products followed by Q-MS during heating humin under Argon (A) and 40 vol. $\% \mathrm{CO}_{2}$ balanced in $\mathrm{Ar}$ (B). Ramp $10{ }^{\circ} \mathrm{C} \cdot \mathrm{min}^{-1}$ 

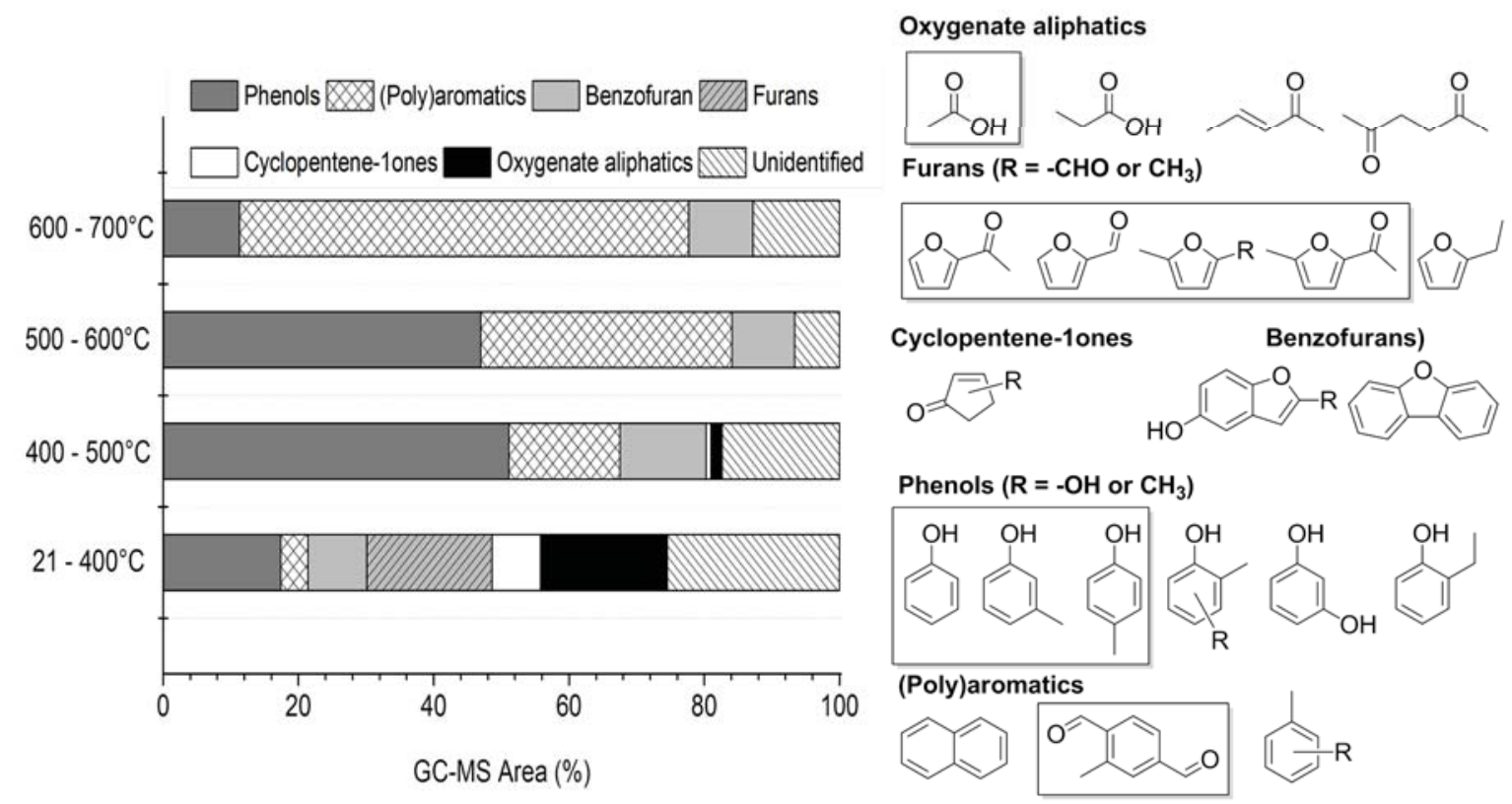

Figure 2.8. Representative condensable volatiles released during de-volatilisation stage. Chemical structures in embedded in frame are those identified in 1-step pyrolysis experiment from RT $-700^{\circ} \mathrm{C}$.

in the matrix) throughout each temperature step. The identified volatiles are classified into six groups: furans, cyclopentene-1ones, benzo-furans, phenols, (poly)-aromatics (excluding phenol type compounds), and oxygenate aliphatics. Components of the volatile mixture from $21-400{ }^{\circ} \mathrm{C}$ are the most diverse with about 60 compounds. Furans, cyclopenten-1ones and some aliphatic oxygenates (e.g., acetic acid, propanoic acid) are present only in this temperature interval. Between 400 and $500{ }^{\circ} \mathrm{C}$ only traces of these are observed. Phenols, (poly)aromatics and benzo-furans are the major constituents of the volatile stream above $400{ }^{\circ} \mathrm{C}$. The components of volatile mixture not only reflect the chemical structure of humin - furan rich but also reveal the complexity of reaction pathways during heating. In addition, secondary reactions of volatiles might still take place during pyrolysis (heating rate $480{ }^{\circ} \mathrm{C} \cdot \mathrm{min}^{-1}$ ). Accordingly, fewer components were observed when the pyrolysis of humin in $\mathrm{CO}_{2}$ atmosphere from RT to $700{ }^{\circ} \mathrm{C}$ was carried out much more rapidly (heating rate $c a$. $\left.975^{\circ} \mathrm{C} \cdot \mathrm{min}^{-1}\right)$.

Solid state ${ }^{13} \mathrm{C}$ NMR can give information about the chemical bonds in humin residues. ${ }^{13} \mathrm{C}$ NMR spectra of humin preheated to 400 and $700{ }^{\circ} \mathrm{C}$ and spectrum of pristine humin in comparison are shown in Figure 2.9. Ketone $(178 \mathrm{ppm})$ and carboxylic functional groups $(210 \mathrm{ppm})$ in pristine humin almost disappear in the 
spectrum of residue at $400{ }^{\circ} \mathrm{C}$. This can be explained by the decarboxylation, decarbonylation to form $\mathrm{CO}_{2}, \mathrm{CO}$ (mentioned above) of carboxylic volatiles (e.g., acetic acid, propanoic acid). No presence of these bands is observed in the $700{ }^{\circ} \mathrm{C}$ residue. The aliphatic region $(0-50 \mathrm{ppm})$ decreases significantly at $400{ }^{\circ} \mathrm{C}$ and vanishes at $700{ }^{\circ} \mathrm{C}$. The most important band, $100-160 \mathrm{ppm}$, changes intensively in shape and peak position. Both bands, at $110 \mathrm{ppm}$ and $150 \mathrm{ppm}$ are representative for furan rings decrease extensively while the band at $127 \mathrm{ppm}$, corresponding to hybridised $\mathrm{sp}^{2}$ of $\mathrm{C}=\mathrm{C}$ bond in aromatic ring, increases sharply for sample preheated at $400^{\circ} \mathrm{C}$. Sample at $700^{\circ} \mathrm{C}$, where the dry reforming initiates, contains one main peak at $127 \mathrm{ppm}$ and a small shoulder at $150 \mathrm{ppm}$. The one at $127 \mathrm{ppm}$ corresponds to (poly)aromatic, graphitic carbon. The shoulder might be attributed to benzo-furan which was also present in the volatiles released at this temperature interval.

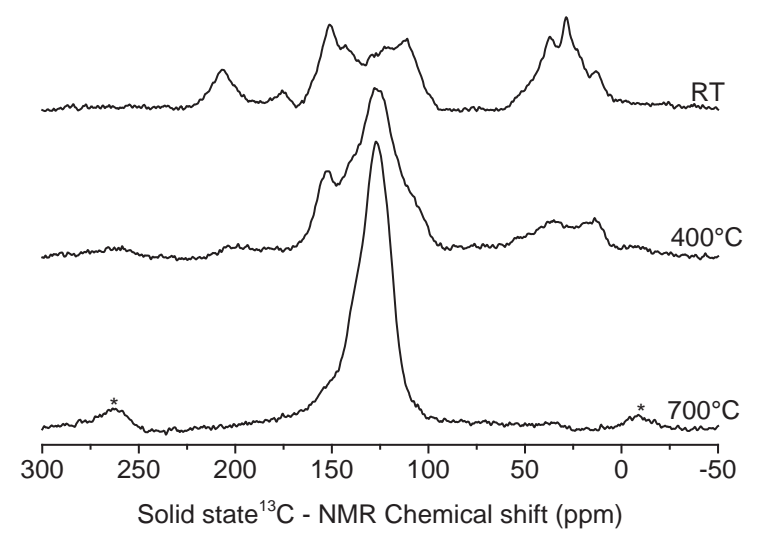

Figure 2.9. Solid state ${ }^{13} \mathrm{C}$ NMR of humin (HG1) residues pre-heated at various temperatures. $*$ is spinning side band

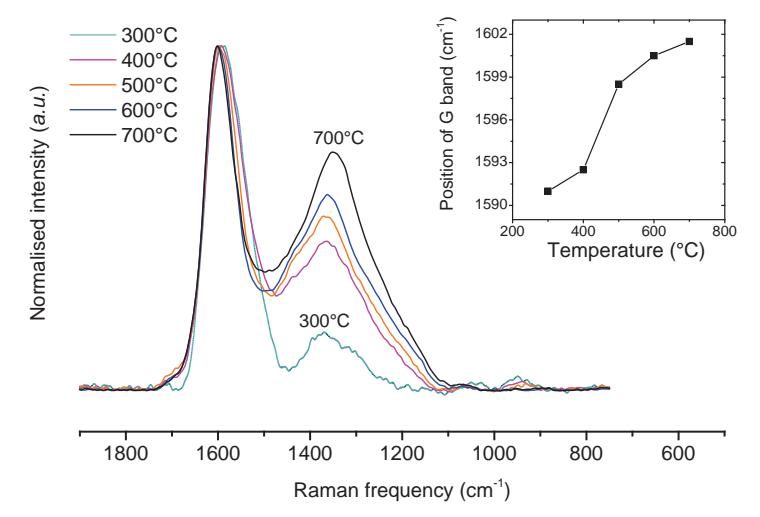

Figure 2.10. Raman spectra of humin residues normalised to $\mathrm{G}$ band height. Inset: position of $\mathrm{G}$ band peak

Raman spectroscopy can be used to analyse the structure of carbon. Figure 2.10 shows the Raman spectra of humin residue heated from 300 to $700{ }^{\circ} \mathrm{C}$. All spectra were normalised to the intensity of the stronger band at $1600 \mathrm{~cm}^{-1}$. It was not possible to record the visual Raman spectrum of pristine humin due to increase of photoluminescence background caused by the high $\mathrm{H}$ content. Spectra of the preheated humin residue consist of two peaks, corresponding to D-band at $1350 \mathrm{~cm}^{-1}$ and G-band at ca. $1600 \mathrm{~cm}^{-1}$. According to Ferrari and Robertson [29], the D and G band are due to $\mathrm{sp}^{2} \mathrm{C}=\mathrm{C}$. The $\mathrm{G}$ band corresponds to the bond stretching of all pairs of $\mathrm{sp}^{2} \mathrm{C}$ in both rings and chains while the $\mathrm{D}$ band is due to the breathing mode of $\mathrm{sp}^{2} \mathrm{C}$ in rings. Those, particular spectra of samples above $400{ }^{\circ} \mathrm{C}$ are typical for carbonised 
carbon materials [30]. A clear increase in $\mathrm{D}$ band to $\mathrm{G}$ band area/height ratio with temperature can easily be observed from Figure 2.10. This means increase in aromatic ring concentration at the higher temperatures [29, 31]. In addition, FHWM of G band peaks is a measure of the crystal order. The narrower $\mathrm{FHWM}_{\mathrm{G}}$, the disorder in $\mathrm{C}$ structure of the residues become decreased. The increase of $\mathrm{G}$ band position (inset of Figure 2.10) with temperature, together with the decrease of $\mathrm{FWHM}_{\mathrm{G}}$ and increased D band to $G$ ban intensity ratio, support the conclusion of transition of humin from amorphous structure to aromatised/graphitised carbon [29].

\subsubsection{Discussion of the change in structure of humin at elevated temperatures}

As mentioned in section 2.3.1, the molecule mass of 301 Dalton (or masses with 300 Dalton difference) was found in all fractions of humin. Chemical formula of $\mathrm{C}_{17} \mathrm{H}_{16} \mathrm{O}_{5}$ can be assigned to this mass. Interestingly, the $\mathrm{C}: \mathrm{H}: \mathrm{O}$ atomic ratio of humin is approximately $17: 13: 5$. We believe that this formula is one of the basic structural units produced from the hydrolysis depolymerisation of solid humin as well as soluble humin.

From spectroscopic analyses (ATR-IR, NMR), as well as from pyrolysis studies, and taking into account literature information $[19,20]$ on hydrothermal carbon (which is similar to highly carbonised humin), we propose structure of the formula $\mathrm{C}_{17} \mathrm{H}_{16} \mathrm{O}_{5}$ as that illustrated in Figure 2.11-A. It is suggested that two furan rings are linked by an acetyl group via $\alpha \mathrm{C}$. This is supported by the presence of 2-acetyl furan or 2-acetyl, 5methyl furan in the pyrolysis products of humin. The acetyl linkage is formed via dehydration of two HMF molecules. $\alpha \mathrm{C}$ can be linked with $\beta \mathrm{C}$ of other furan ring by

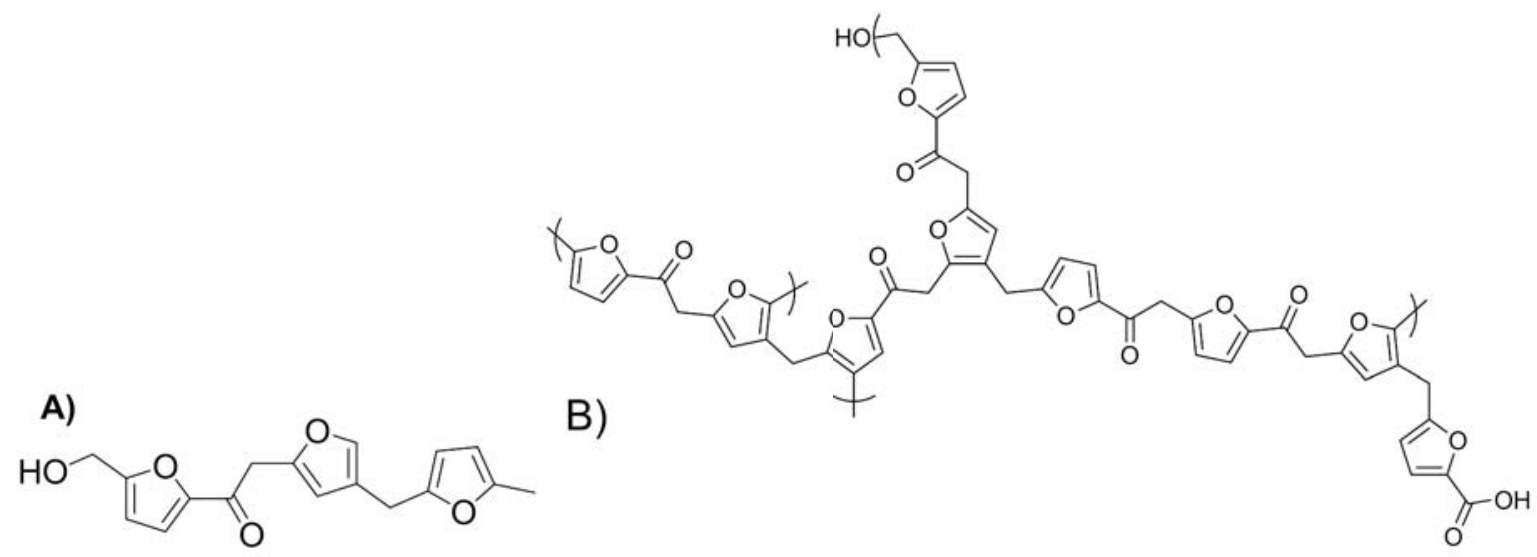

Figure 2.11. Chemical structure of humin segment with mass of 300 Dalton and proposed model of humin constructed from that segment $\left(\mathrm{C}_{52} \mathrm{H}_{40} \mathrm{O}_{17}\right.$-from 3 units) 
$\mathrm{CH}_{2}$ linkage. Figure 2.11-B shows the proposed representative structure of humin which is constructed from three proposed units with a carboxylic functional group. It corresponds to the chemical formula of $\mathrm{C}_{52} \mathrm{H}_{40} \mathrm{O}_{17}$. In this report the suggested humin structure is formed via a de-hydration pathway of furan type species. It should be noticed that other active components in the medium of de-hydration of sugars such as levulinic acid, formic acid, sugar intermediates can also graft to humin matrix via condensation reactions. This model structure shares some common features with the structure of humin from glucose proposed by Van Zandvoort et al. [19]. However, in our model, acetyl is the major linkage between furan rings due to the consistent presence of acetyl groups in spectroscopic and pyrolysis characterisation analysis. Meanwhile, ethyl/ethylene is proposed as major linkage between furan rings in that literature.

By various characterisation techniques shown in section 2.3.2, it is concluded that thermal treatment has very strong influence on humin. Humin undergoes a lot of changes in texture, composition and chemical structure upon heating prior to it reaching gasification temperatures. De-oxygenation, de-volatilisation of humin occurs at elevated temperatures. Humin becomes, as a result, more aromatised, graphitised. The actual humin feedstock for gasification contains mainly $\mathrm{C}$ (above 90 wt.\%) in graphitic/aromatic structure with few oxygen containing groups (e.g., phenolic or benzo-furan). Therefore, the gasification of humin is expected to resemble those of bio-char or coals.

\subsubsection{Dry reforming of humin}

Due to the inert, low reactivity of graphitic carbon, thermal reforming of humin would also be difficult. Dry reforming reactions of humin residue at elevated temperatures (above $700^{\circ} \mathrm{C}$ ) can be simplified as following:

$$
\begin{aligned}
& \mathrm{C}_{61.3} \mathrm{H}_{16} \mathrm{O}_{3}+61.3 \mathrm{CO}_{2} \rightarrow 122.6 \mathrm{CO}+5 \mathrm{H}_{2}+3 \mathrm{H}_{2} \mathrm{O}(\mathrm{Eq} 1) \\
& \mathrm{C}_{61.3} \mathrm{H}_{16} \mathrm{O}_{3}+58.3 \mathrm{CO}_{2} \rightarrow 119.6 \mathrm{CO}+8 \mathrm{H}_{2}(\mathrm{Eq} 2)
\end{aligned}
$$

Where $\mathrm{C}_{61.3} \mathrm{H}_{16} \mathrm{O}_{3}$ is the simplified chemical formula based on the $\mathrm{CHO}$ analysis of humin residue preheated at $700{ }^{\circ} \mathrm{C}$. Eq 1 illustrates the conversion of $\mathrm{H}$ and $\mathrm{O}$ in humin via dehydration and dehydrogenation while the $\mathrm{O}$ in humin releases in the form of $\mathrm{CO}$ in Eq 2. The dry reforming of humin was studied based on TGA which monitors the change of sample mass as function of time on stream (TOS) and temperature. Selectivity of products which only can comprise $\mathrm{CO}, \mathrm{H}_{2}$ and $\mathrm{H}_{2} \mathrm{O}$ could not be 
analysed and quantified. However, from Eq.1 and Eq.2, if humin is completely converted to syngas, beside minor amount of water, selectivity of $\mathrm{H}_{2}$ is in the range of $4-6 \%$. $\mathrm{CO}$ is the main product of dry reforming of humin.
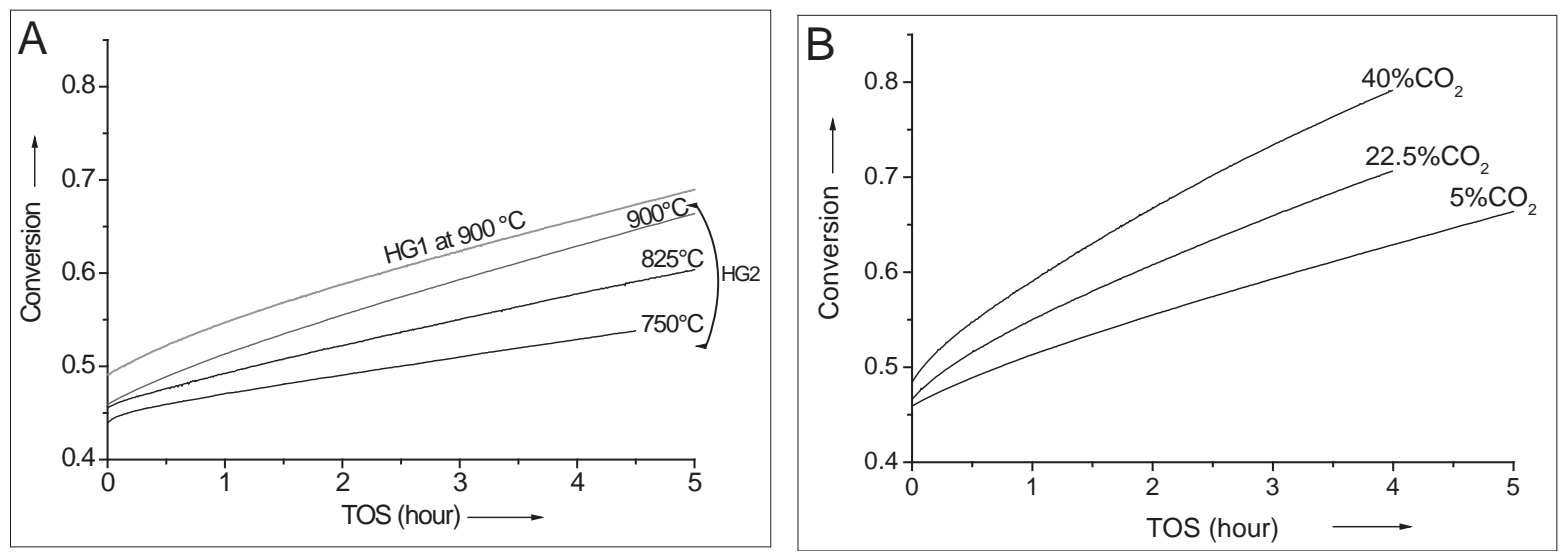

Figure 2.12. Thermal dry reforming of purified humin (HG2): A - influence of temperature (isothermal gasification, 5 vol.\% $\mathrm{CO}_{2}$ ), the grey line represents for conversion of pristine humin (HG1); $\mathrm{B}$ - the influence of $\mathrm{CO}_{2}$ partial pressure - reaction order (isothermal at $900^{\circ} \mathrm{C}$ ). The initial conversions correspond to weight loss in preheating step

Figure 2.12-A shows the thermal (non-catalytic) dry reforming of purified humin samples (HG2) at various temperatures using the same preheating conditions (10 ${ }^{\circ} \mathrm{C} . \mathrm{min}^{-1}$ ). At $750{ }^{\circ} \mathrm{C}$, after $4.5 \mathrm{~h}$ time on stream, only $7 \mathrm{wt} . \%$ is converted. Even at 900 ${ }^{\circ} \mathrm{C}$, only $20 \mathrm{wt} . \%$ of humin is gasified. Compared with lingo-cellulosic char, reactivity of humin is much lower $[32,33]$. This is due to lack of mineral in the humin derived from glucose meanwhile chars from natural lignocellulosic biomass always contains a certain percentage of potassium or other minerals which act as catalyst for the reforming reactions. It should be mentioned that HG2 was used in order to investigate the intrinsic reactivity of pure humin (viz. without the contamination of the entrapped sugar derivatives). However, the slope of conversion curve for gasification of pristine humin (HG1) at $900{ }^{\circ} \mathrm{C}$ - the grey line in Figure 2.12-A is almost similar with that of purified humin. This implies those two residues have similar reactivity towards the dry reforming reactions. The impact of the char formed from the sugar derivatives in HG1 during the de-volatilisation stage is minor due to two possibilities: (i) low amounts or (ii) its reactivity falls in the same range of purified humin.

Apparent kinetic orders of the reforming reaction were investigated and the result is shown in Figure 2.12-B. The dry reforming of humin is performed at atmospheric condition. Therefore, $\mathrm{CO}_{2}$ concentration of 5, 22.5, 40 vol.\% (balanced in 
Ar) corresponds to $\mathrm{CO}_{2}$ partial pressure of 5066, 22780, $40530 \mathrm{~Pa}$, respectively. Reaction orders, calculated by applying power law model or shrinking model for kinetic reactions of dry reforming, varies from $0.27-0.35$. It should be noticed that the reactivity of humin depend on the conversion levels. The low value of reaction order is another proof for the inert nature of humin residue.

\subsection{Conclusions}

Humin formation is one of major problems in conversion of carbohydrates to value added platform chemicals (e.g., HMF, LA, and FF). Despite significant carbon selectivity to humin, understanding of the pathways of its formation, chemical structure as well as its application in bio-refinery scheme is still limited. Structural analysis of humin and humin fractions were done in this study in addition to investigation of the influence of thermal treatment on humin. Although pristine humin has complex furanrich structure with multiple oxygen functional groups, heating humin at elevated temperature (to reach to reforming temperature) leads to de-volatilisation and aromatisation/graphitisation. The volatile organic components released during heating were identified. They can be reformed to syngas in a second stage thereby converting the whole humin feedstock or used as a source of potential chemicals. Only graphitic type carbon structure is left prior the gasification. Its inert nature causes thermal dry reforming very difficult at mild gasification conditions. The use of catalyst is required to improve the reforming rate, thus making the process more viable.

\section{Bibliography}

[1] D.M. Alonso, J.Q. Bond, J.A. Dumesic, Catalytic conversion of biomass to biofuels, Green Chemistry, 12 (2010) 1493-1513.

[2] B. Kamm, M. Kamm, Principles of biorefineries, Applied microbiology and biotechnology, 64 (2004) 137-145.

[3] E. Taibi, D. Gielen, M. Bazilian, The potential for renewable energy in industrial applications, Renew Sust Energ Rev, 16 (2012) 735-744.

[4] A.J. Ragauskas, C.K. Williams, B.H. Davison, G. Britovsek, J. Cairney, C.A. Eckert, W.J. Frederick, Jr., J.P. Hallett, D.J. Leak, C.L. Liotta, J.R. Mielenz, R. Murphy, R. Templer, T. Tschaplinski, The path forward for biofuels and biomaterials, Science, 311 (2006) 484-489.

[5] G.W. Huber, S. Iborra, A. Corma, Synthesis of transportation fuels from biomass: chemistry, catalysts, and engineering, Chemical reviews, 106 (2006) 4044-4098.

[6] J.J. Bozell, Feedstocks for the Future - Biorefinery Production of Chemicals from Renewable Carbon, CLEAN - Soil, Air, Water, 36 (2008) 641-647. 
[7] J.N. Chheda, G.W. Huber, J.A. Dumesic, Liquid-phase catalytic processing of biomassderived oxygenated hydrocarbons to fuels and chemicals, Angew Chem Int Ed Engl, 46 (2007) 7164-7183.

[8] J.J. Bozell, G.R. Petersen, Technology development for the production of biobased products from biorefinery carbohydrates - the US Department of Energy's "Top 10" revisited, Green Chemistry, 12 (2010) 539.

[9] T. Werpy, G. Petersen, Top Value Added Chemicals from Biomass: Volume 1-Results of Screening for Potential Candidates from Sugars and Synthesis Gas, in, National Renewable Energy Laboratory, 2004.

[10] B. Girisuta, L.P.B.M. Janssen, H.J. Heeres, Kinetic Study on the Acid-Catalyzed Hydrolysis of Cellulose to Levulinic Acid, Industrial \& Engineering Chemistry Research, 46 (2007) 1696-1708.

[11] R. Weingarten, W.C. Conner, G.W. Huber, Production of levulinic acid from cellulose by hydrothermal decomposition combined with aqueous phase dehydration with a solid acid catalyst, Energy \& Environmental Science, 5 (2012) 7559-7574.

[12] D.M. Alonso, S.G. Wettstein, J.Q. Bond, T.W. Root, J.A. Dumesic, Production of biofuels from cellulose and corn stover using alkylphenol solvents, ChemSusChem, 4 (2011) 1078-1081.

[13] R. Weingarten, G.A. Tompsett, W.C. Conner, G.W. Huber, Design of solid acid catalysts for aqueous-phase dehydration of carbohydrates: The role of Lewis and Brønsted acid sites, Journal of Catalysis, 279 (2011) 174-182.

[14] B.F.M. Kuster, L.M. Tebbens, Analytical Procedures for Studying the Dehydration of DFructose, Carbohydrate research, 54 (1977) 159-164.

[15] X. Hu, C. Lievens, A. Larcher, C.Z. Li, Reaction pathways of glucose during esterification: effects of reaction parameters on the formation of humin type polymers, Bioresource technology, 102 (2011) 10104-10113.

[16] B. Girisuta, L.P.B.M. Janssen, H.J. Heeres, A kinetic study on the decomposition of 5hydroxymethylfurfural into levulinic acid, Green Chemistry, 8 (2006) 701.

[17] N. Shi, Q.Y. Liu, Q. Zhang, T.J. Wang, L.L. Ma, High yield production of 5hydroxymethylfurfural from cellulose by high concentration of sulfates in biphasic system, Green Chemistry, 15 (2013) 1967-1974.

[18] T.S. Nguyen, M. Zabeti, L. Lefferts, G. Brem, K. Seshan, Catalytic upgrading of biomass pyrolysis vapours using faujasite zeolite catalysts, Biomass and Bioenergy, 48 (2013) 100110. 
[19] I. van Zandvoort, Y. Wang, C.B. Rasrendra, E.R. van Eck, P.C. Bruijnincx, H.J. Heeres, B.M. Weckhuysen, Formation, Molecular Structure, and Morphology of Humins in Biomass Conversion: Influence of Feedstock and Processing Conditions, ChemSusChem, (2013).

[20] N. Baccile, G. Laurent, F. Babonneau, F. Fayon, M.-M. Titirici, M. Antonietti, Structural Characterization of Hydrothermal Carbon Spheres by Advanced Solid-State MAS13C NMR Investigations, The Journal of Physical Chemistry C, 113 (2009) 9644-9654.

[21] M.J. Antal, W.S.L. Mok, G.N. Richards, Kinetic-Studies of the Reactions of Ketoses and Aldoses in Water at High-Temperature .1. Mechanism of Formation of 5-(Hydroxymethyl)-2Furaldehyde from D-Fructose and Sucrose, Carbohydrate research, 199 (1990) 91-109.

[22] C. Yao, Y. Shin, L.Q. Wang, C.F. Windisch, W.D. Samuels, B.W. Arey, C. Wang, W.M. Risen, G.J. Exarhos, Hydrothermal Dehydration of Aqueous Fructose Solutions in a Closed System, Journal of Physical Chemistry C, 111 (2007) 15141-15145.

[23] B.F.M. Kuster, L.M. Tebbens, Analytical proceduce for stuying the dehydration of Dfructose, Carbohydrate Research, 54 (1977) 158-164.

[24] G. Almendros, J. Sanz, L. Sobrados, Characterization of synthetic carbohydrate-derived humic-like polymers, The Science of the Total Environment,, 81-82 (1989) 91-98.

[25] C. Falco, N. Baccile, M.-M. Titirici, Morphological and structural differences between glucose, cellulose and lignocellulosic biomass derived hydrothermal carbons, Green Chemistry, 13 (2011) 3273.

[26] T.M.C. Hoang, L. Lefferts, K. Seshan, Valorization of humin-based byproducts from biomass processing-a route to sustainable hydrogen, ChemSusChem, 6 (2013) 1651-1658.

[27] R.K. Sharma, J.B. Wooten, V.L. Baliga, M.R. Hajaligol, Characterization of chars from biomass-derived materials: pectin chars, Fuel, 80 (2001) 1825-1836.

[28] C. Falco, F. Perez Caballero, F. Babonneau, C. Gervais, G. Laurent, M.M. Titirici, N. Baccile, Hydrothermal carbon from biomass: structural differences between hydrothermal and pyrolyzed carbons via 13C solid state NMR, Langmuir : the ACS journal of surfaces and colloids, 27 (2011) 14460-14471.

[29] A.C. Ferrari, J. Robertson, Raman spectroscopy of amorphous, nanostructured, diamondlike carbon, and nanodiamond, Philosophical transactions. Series A, Mathematical, physical, and engineering sciences, 362 (2004) 2477-2512.

[30] M. Sevilla, A.B. Fuertes, The production of carbon materials by hydrothermal carbonization of cellulose, Carbon, 47 (2009) 2281-2289.

[31] X.J. Li, J. Hayashi, C.Z. Li, FT-Raman spectroscopic study of the evolution of char structure during the pyrolysis of a Victorian brown coal, Fuel, 85 (2006) 1700-1707.

[32] P. Ollero, A. Serrera, R. Arjona, S. Alcantarilla, The CO2 gasification kinetics of olive residue, Biomass Bioenerg, 24 (2003) 151-161. 
[33] C. Di Blasi, Combustion and gasification rates of lignocellulosic chars, Progress in Energy and Combustion Science, 35 (2009) 121-140.

\section{Appendix 2}

\section{i. Experimental}

Water solubility of humin experiment was carried out and estimated based on "TAPPI T207 cm-99 Standard". Ca. 1g humin was refluxed in 100ml water in $250 \mathrm{ml}$ Erlenmeyer flash. The flask with humin was placed in a boiling water bath for $3 \mathrm{~h}$. After that humin was filtered and dried to constant weight at $105 \pm 3^{\circ} \mathrm{C}$.

One percent sodium hydroxide solubility of humin was determined using "TAPPI T212 om-02 Standard". $\mathrm{Ca}$. $1 \mathrm{~g}$ humin was dispersed in $100 \mathrm{ml}$ of $1 \% \mathrm{NaOH}$ solution in a $200 \mathrm{ml}$ beaker. The beaker with a watch glass cover is kept in a water bath maintained at $98 \pm 2{ }^{\circ} \mathrm{C}$ for 60 minutes. The solution was stirred with glass rod at 10, 15 and 25 minute after placing in the bath. After 60 minutes, humin was filter and washed with $100 \mathrm{ml}$ hot water then $25 \mathrm{ml}$ $\mathrm{CH}_{3} \mathrm{COOH} 10 \mathrm{wt} . \%$ (soaked for 1 minute before removal). The water - acetic acid washing was repeated 2 times. Then humin was washed with hot water until acid free. Finally humin (together with tarred filter paper) was dried to constant weight at $105 \pm 3^{\circ} \mathrm{C}$ in a tarred drying cup.

Acetone extractives of humin was carried out according to "TAPPI T204 cm-97 Standard". An extraction thimble with $\sim 1 \mathrm{~g}$ humin was placed in a clean and dry Soxhlet extraction apparatus. $150 \mathrm{ml}$ acetone was used for the extraction. Heating power was adjusted so that it was allowed the solvent to cycle every $\sim 10 \mathrm{~min}$. The extraction was kept for $8 \mathrm{~h}$. After that the solvent solution containing humin extracts was evaporated in a tarred extraction flask to near dryness. The flask was then dried in vacuum oven at $30^{\circ} \mathrm{C}$ for $1 \mathrm{~h}$.

Solubility of humin was estimated as following:

Solubility in hot water or $1 \% \mathrm{NaOH}=100 \% \times \frac{\mathrm{w}_{0}-\mathrm{W}}{\mathrm{w}_{0}}$ Solubility in acetone $=100 \% \times \frac{\mathrm{W}_{\mathrm{e}}}{\mathrm{W}_{0}}$

Where $\mathrm{w}_{0}, \mathrm{w}$ and $\mathrm{w}_{\mathrm{e}}$ is the oven-dry of humin before extraction and after extraction and oven-dry weight of extract after acetone extraction respectively.

\section{ii. Results}




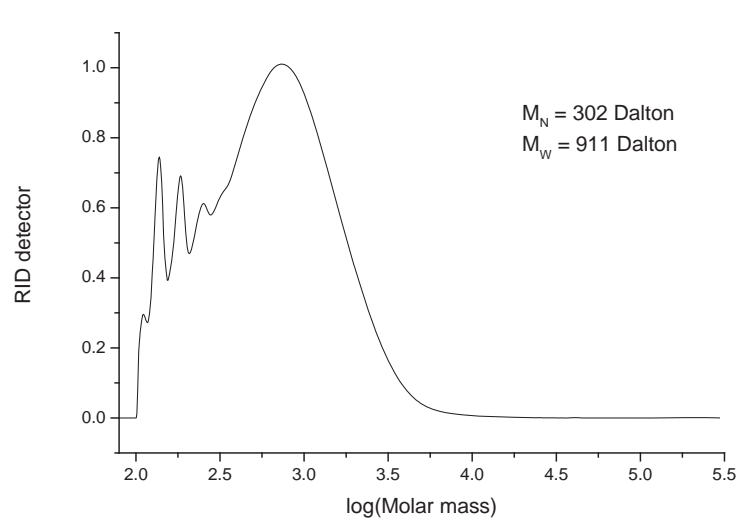

A.2.1. GPC result of acetone soluble fraction of humin

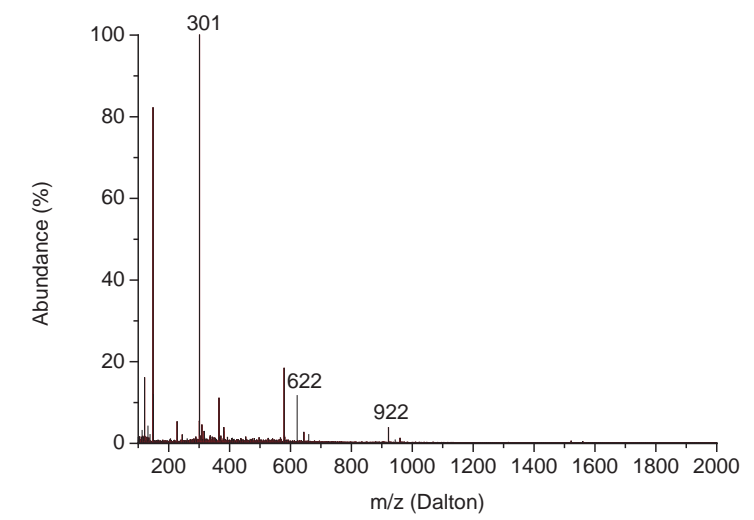

A.2.3. ESI MS (in positive mode) of solvent solution obtained in the experiment of $\mathrm{NaOH}$ $1 \%$ solubility of humin

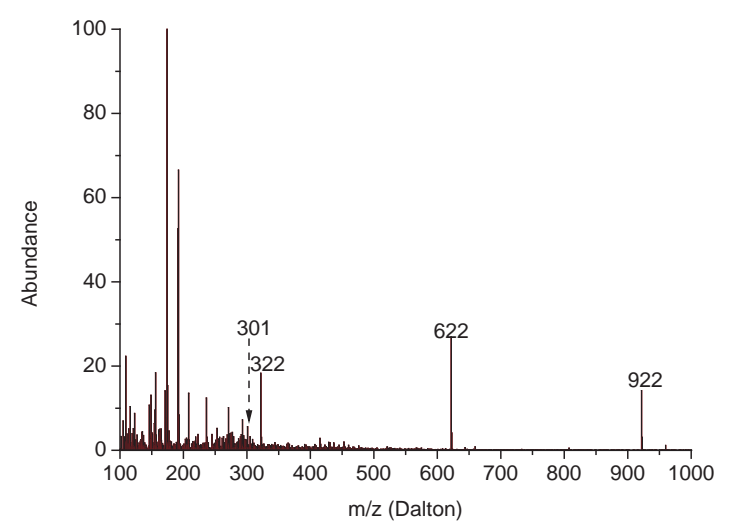

A.2.2. ESI MS (in positive mode) of solvent after the hot water soluble extraction of humin

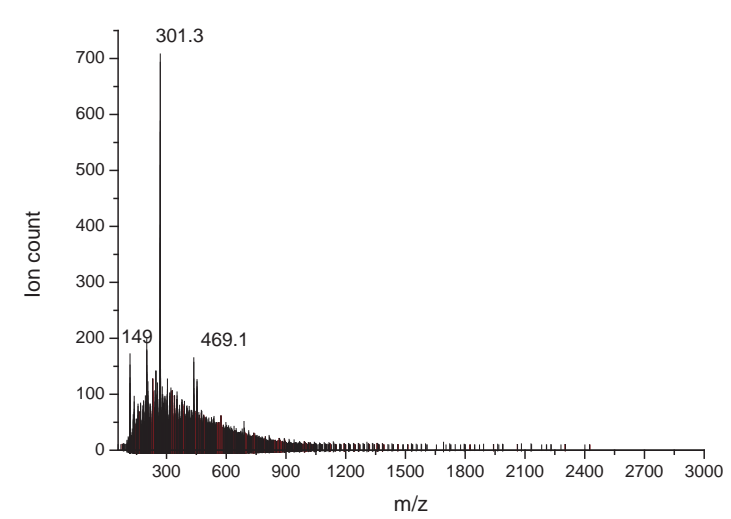

A.2.4.. LDI-TOF Mass spectrum of pristine humin

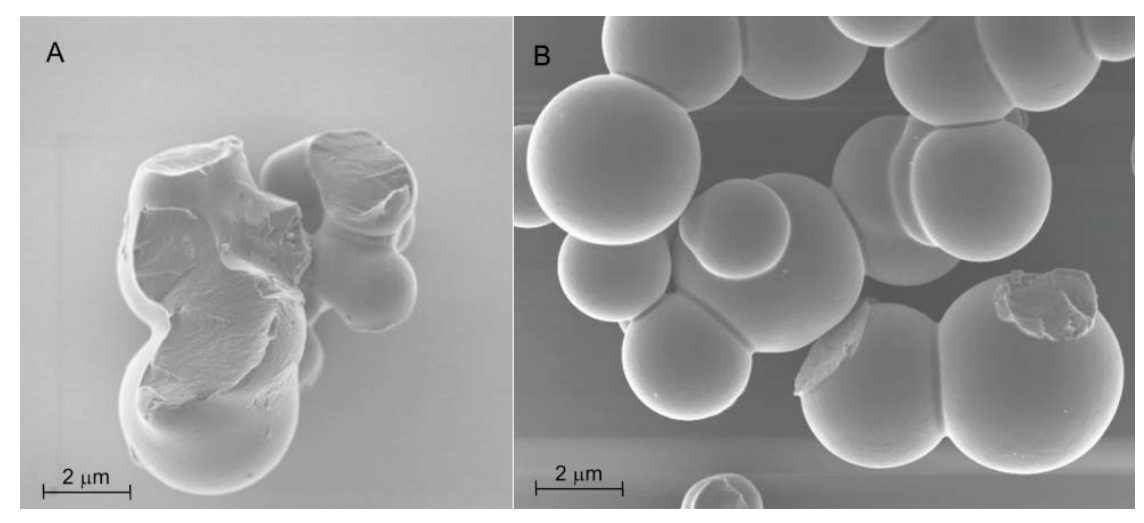

A.2.5. SEM image of humin residue (A - HG1, B- HG1_NaOH1\%) after anealing in $\mathrm{N}_{2}$ at $700{ }^{\circ} \mathrm{C}$. No hollow sphere structure was formed 


\title{
Valorisation of humin-based by-products from biomass processing - A route to sustainable hydrogen
}

\begin{abstract}
Valorisation of humin by steam reforming for $\mathrm{H}_{2}$ is discussed in this chapter. Both thermal and catalytic steam gasification were investigated systematically. Humin undergoes drastic changes under thermal pre-treatment to the gasification temperatures. Alkali-metal-based catalysts were screened for the reactions. $\mathrm{Na}_{2} \mathrm{CO}_{3}$ showed the highest activity and was selected for further study. The presence of $\mathrm{Na}_{2} \mathrm{CO}_{3}$ enhances the gasification rate drastically, and gas-product analysis shows that the selectivity to $\mathrm{CO}$ and $\mathrm{CO}_{2}$ is $75 \%$ and $25 \%$ respectively, with a $\mathrm{H}_{2} / \mathrm{CO}$ ratio of 2 (corresponding to $81.3 \% \mathrm{H}_{2}$ as compared to thermodynamic equilibrium). A possible process for the complete, efficient conversion of humin is outlined.
\end{abstract}




\subsection{Introduction}

Over the last century, mankind witnessed the dramatic development of life standard which is mainly based on petroleum economy. However, along with the use of fossil materials, the global temperature has been increasing with the rate that far surpasses the natural variability of the last years [1]. The greenhouse gas emission (e.g., $\mathrm{CH}_{4}, \mathrm{CO}_{2}, \mathrm{~N}_{2} \mathrm{O}$ ) produced from anthropogenic activities such as burning fossil fuels is responsible for the global warming. The depletion of fossil fuels as well as influence of climate change on economy and ecology has generated great interest in searching for sustainable alternative resources. Biomass is considered as the only sustainable carbon containing resource for our chemical and material industry [2-5]. Furans (including 5-hydroxy methyl furfural - HMF, furfural) and levulinic acid are among Top ten value added chemical platforms from bio-derived carbohydrates [6]. The synthesis of these molecules from lignocellulosic biomass involves multiple acid catalysed processes (e.g., hydrolysis of (hemi)cellulose, dehydration of the corresponding sugars) [7-9]. One of the major problems of these processes is formation of large amount solid by-products, generally called humin. The yield of the waste can be as high as $40-50 \%$ (on carbon basis) [8-11]. Therefore, an efficient use of humin is essential. Since it can maximise the use of carbon source, reduce total waste of the overall process. Thus it improves the E factor and feasibility of the conversion route from biomass to HMF or levulinic acid.

Generally, humin consists of carbon-rich agglomerate particles [12-14]. It is composed of approximately 50 - $66 \mathrm{wt} . \%$ carbon, $29-46 \% \mathrm{wt} . \%$ oxygen and the remainder is hydrogen $[12,14]$. The only application of humin so far is to generate heat by combustion. Interestingly, most of the conversions in bio-refinery involve a hydrogenation step. This requires the import of hydrogen from external fossil sources, which is expensive and not sustainable. In this context, the efficient conversion of humin to syngas $\left(\mathrm{CO}+\mathrm{H}_{2}\right)$ or hydrogen is extremely interesting. Hydrogen generation from humin would allow the complete usage of the feedstock in the sugar conversion processes by generating hydrogen from what is normally considered as a waste product. To the best of our knowledge, the valorisation of humin through hydrogen production has not been reported in the literature.

Conventionally, the gasification of solid, carbon rich materials such as char or coal is performed thermally in steam or oxygen. This requires the gasification temperature to be above $1000{ }^{\circ} \mathrm{C}$ due to the high endothermicity of the reactions. The gasification of the solid feedstock, for example, coal, char or biomass, involves two stages. The first stage is devolatilisation in which biomass decomposes and gas/volatiles escape from the solid substrates 
under heating to gasification temperature. This is followed by the gasification stage in which the remainder reacts with oxidative reagents (steam, carbon dioxide or oxygen).

Catalytic gasification is advantageous over the thermal process because of the improvement of reactivity, and thus the decrease of the reaction temperature. Moreover, tar, which is often formed during the conversion of highly carbonaceous materials, can be gasified completely in the presence of a catalyst. The catalytic gasification of biomass and biomassderived syngas has been reviewed by Sutton et. al. [15], Dayton [16] and Yung et al.[17] According to Sutton et al., catalysts used in biomass gasification can be divided into two distinct groups. The primary catalysts are generally added directly to the biomass prior to gasification. They enhance the gasification rate of the remaining char. The second group of catalysts helps in tar destruction, hence increases gas yields.

Despite extensive studies on the development of efficient catalysts for the reforming of oxygenate biomass-based compounds and tar, catalysts in the first group are based on conventional, off-the-shelf materials. Usually inexpensive, disposable materials such as dolomite, alkali metals or alkaline earth metals are used as primary catalysts [15]. It is wellknown that alkali metals enhance the reactivity of biomass, char and coal in dry or steam reforming [18-20]. The gasification rate is improved dramatically. In addition, alkali metals are moderately active towards tar reforming [17].

This chapter focuses on the catalytic steam reforming/ gasification of humin with a view to provide a complete sustainable process for carbohydrate conversions in the biorefinery concept. Alkali metal based catalysts were investigated and the complexity of humin gasification is discussed.

\subsection{Experimental Section}

All chemicals used in this study were of analytical or spectroscopic grade (SigmaAldrich) and used without further purification.

\subsubsection{Humin preparation, purification and thermal pre-treatment}

Humin samples used in the study were prepared via dehydration of D-glucose followed by a Soxhlet extraction with for 24 hours. Detail of the preparation and purification was described in Chapter 2.

In the case of catalytic gasification, the humin was dry-mixed with catalyst using a Fluxana mixer (MU-K-Mixer_50Hz). Typically, dried humin $(\sim 1 \mathrm{~g})$ with the required amount of catalyst was shaken in a mixing beaker for 20 minutes. The catalyst loading is 
defined as the weight percentage of alkali metal compared with weight of dried humin (e.g., $1.5 \% \mathrm{Na}$ corresponds to 3.45 wt. unit of $\mathrm{Na}_{2} \mathrm{CO}_{3}$ in 100 wt. unit of dried humin).

Samples for elemental analysis and Nuclear Magnetic Resonance (NMR) experiments were prepared by heating humin or a humin mixture $(\sim 1 \mathrm{~g})$ in a calcination furnace under a flow of Argon (50 ml. $\left.\mathrm{min}^{-1}\right)$ saturated with water at room temperature. The furnace temperature was increased at the rate of $10{ }^{\circ} \mathrm{C} \cdot \mathrm{min}^{-1}$ and kept at the desired temperatures for 0.2 hour and then cooled down to room temperature.

\subsubsection{Characterization}

Elemental composition, specific area and HR-SEM images of humin residues were recorded with the correspondent characterisation setups which were described in Chapter 2 with the same condition and parameters.

${ }^{13} \mathrm{C}$ Cross Polarization with Magic Angle Spinning (CP-MAS) NMR spectra of humin residue were acquired using a $20 \mathrm{~T}$ Varian system at a MAS frequency of $20 \mathrm{kHz}$ with a 3.2 $\mathrm{mm}$ MAS probe. The recycle delay and cross polarisation contact time were $5 \mathrm{~s}$ and $1 \mathrm{~s}$, respectively. The spectra were referenced to adamantane.

Pyrolysis experiments were performed as described elsewhere [21]. Argon saturated with water at room temperature was used to mimic the steam gasification conditions. The condensable products were diluted with acetone and analysed by using an Agilent 7890AGC coupled with a 5975C MS. The identification was performed with reference to the NIST 2008 library.

\subsubsection{Thermo-gravimetric Analysis (TGA) and gasification experiments}

TGA experiments were performed by using a Mettler Toledo analyser (TGA/ SDTA/851e) with samples of $2-3 \mathrm{mg}$ initial weight, and a $65 \mathrm{ml} \mathrm{min}^{-1}$ flow rate of argon or water-saturated argon at room temperature. The initial weight was small enough to avoid mass-transfer limitations (experiments show that the conversion rate is independent of the sample mass below $5 \mathrm{mg}$ ). Typically, samples were first heated to $105{ }^{\circ} \mathrm{C}$ at $10^{\circ} \mathrm{C} \cdot \mathrm{min}^{-1}$ and held for $1 \mathrm{~h}$ to remove any physically adsorbed water; then heated to the desired temperatures and held for the required time. The exhaust gas from TGA was analysed by using on-line MS.

All conversion values used in this study are cumulative and calculated as following:

$$
\text { Conversion }\left(\mathrm{X}_{\mathrm{i}}\right)=\frac{\mathrm{m}_{0}-\mathrm{m}_{\mathrm{i}}}{\mathrm{m}_{0}-\mathrm{m}_{\text {salt }}} \quad(\mathrm{w} / \mathrm{w})
$$


Residue weight $=1-\mathrm{X}_{\mathrm{i}}$

Gasification rate $=\frac{\delta X_{i}}{\delta t}\left(\min ^{-1}\right)$

Where: $\mathrm{m}_{0}, \mathrm{~m}_{\mathrm{i}}$ are mass of humin mixture part after in situ drying at $105{ }^{\circ} \mathrm{C}$ for 1 hour and at interest point respectively; $\mathrm{m}_{\text {salt }}$ is the mass of catalyst; $\mathrm{X}_{\mathrm{i}}$ is conversion at interest point.

Catalytic flow experiments were performed in a fixed-bed reactor. About $35 \mathrm{mg}$ of humin with sodium catalyst pre-heated at $700{ }^{\circ} \mathrm{C}$ was held in place by quartz wool plugs in an $\alpha$-alumina reactor ( $4 \mathrm{~mm}$ internal diameter). Then samples were heated to $750{ }^{\circ} \mathrm{C}$ under argon flow $\left(30 \mathrm{ml} \cdot \mathrm{min}^{-1}\right)$ at a heating rate of $10^{\circ} \mathrm{C} \cdot \mathrm{min}^{-1}$. When temperature reached $750{ }^{\circ} \mathrm{C}$, the feed-stream was switched to argon saturated with water at room temperature. Gas compositions were determined with an online three-channel gas chromatograph (GC, Varian CP-3800). Each analysis takes $\sim 19$ minute. The GC is equipped with five gas separation columns (Haysep Q, Haysep T, Molsieve 13X, Molsieve 5A and CP-Wax 52CB) using two thermal conductivity detector (TCD) and a flame ionization detector (FID).

\subsection{Results and discussion}

\subsubsection{Thermal steam gasification of humin}

The steam gasification of carbon-based materials, for example, coal and methane, is favored at higher temperatures according to thermodynamics [22].

Figure 3.1 shows changes in the weight of a humin sample as a function of temperature during a thermo-gravimetric analysis (TGA) experiment. The experiment was performed to high temperatures to include typical gasification temperatures. It can be seen from Figure 3.1 that continuous weight

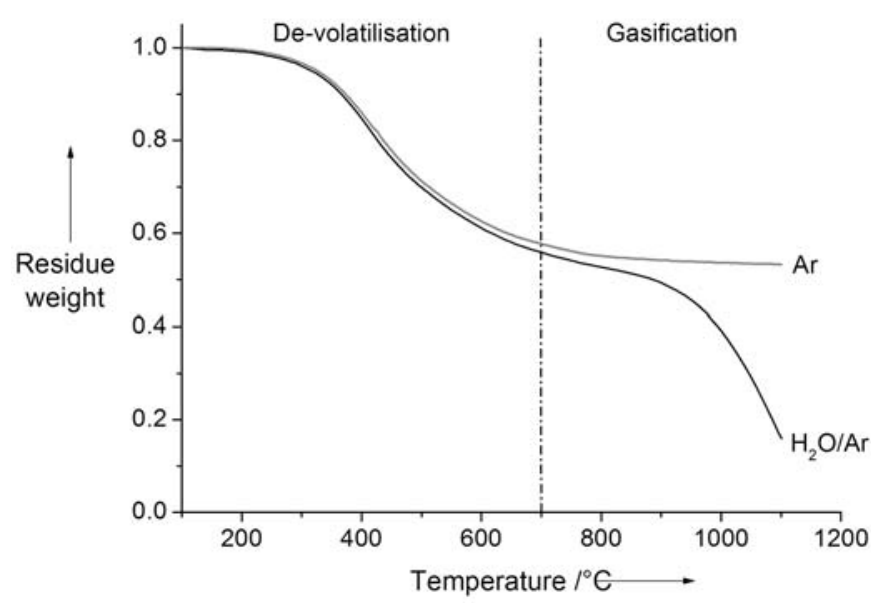

Figure 3.1. Thermo-gravimetric analysis of humin in $\mathrm{Ar}$ (gray line) or $\mathrm{H}_{2} \mathrm{O} / \mathrm{Ar} 1.75$ vol.\% (black line), heating rate of $10^{\circ} \mathrm{C} \mathrm{min}^{-1}$. loss occurs until approximately $700{ }^{\circ} \mathrm{C}$ followed by a stable region and further loss of weight in the presence of water above 
$750{ }^{\circ} \mathrm{C}$. If we consider that no changes occur in the absence of water above $750{ }^{\circ} \mathrm{C}$, this region indicates the occurrence of steam gasification. Below $700{ }^{\circ} \mathrm{C}$, we attribute the weight changes to the liberation of volatile products from the humin sample. Analysis of the condensable fraction of the volatiles by GC-MS indicated the presence of acetic acid, furfural/phenol, derivatives and poly-aromatic tars, for example naphthalene. Significantly, this corresponds to about $45 \mathrm{wt}$. \% of the humin sample that is lost before it reaches gasification temperature.
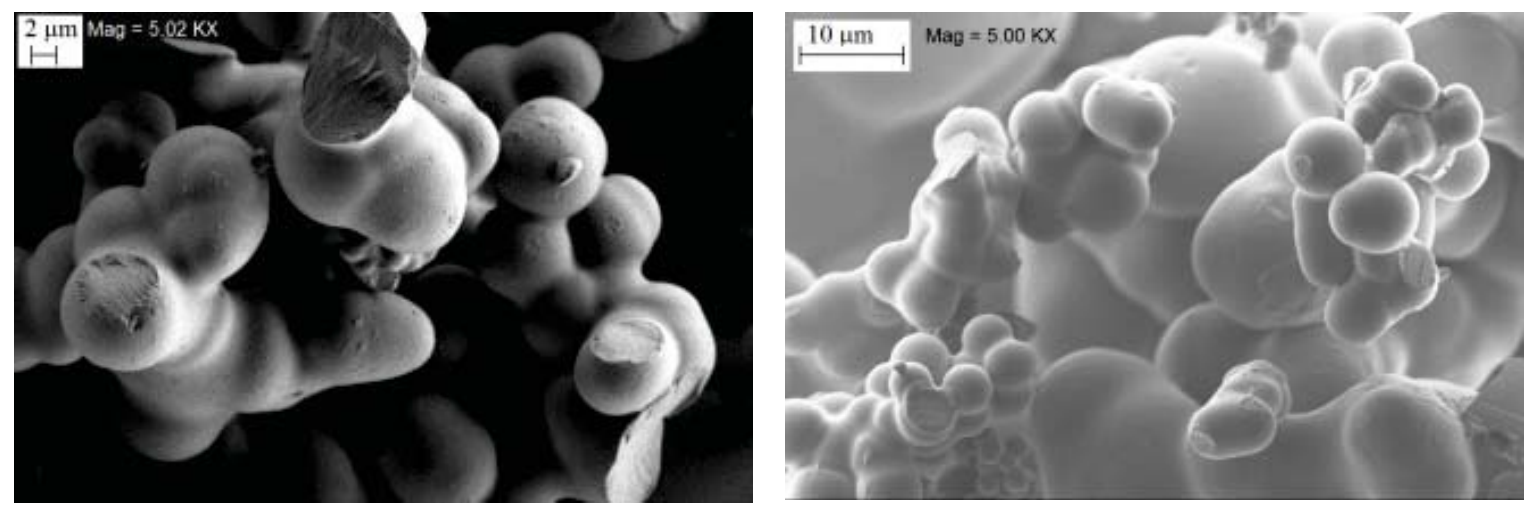

Figure 3.2. HR-SEM images of humin, fresh (left) and after heating in $\mathrm{H}_{2} \mathrm{O} / \mathrm{Ar}$ at $700{ }^{\circ} \mathrm{C}$ for $0.2 \mathrm{~h}$ (right).

High resolution SEM (HR-SEM) images of the humin sample during the two stages of the experiment (described above, room temperature and $700{ }^{\circ} \mathrm{C}$ ) are shown in Figure 3.2. Hardly any morphological differences are seen in the two images. The humin sample retains its shape and size despite the $40 \%$ weight loss. However, the specific surface area of the fresh sample was negligible whereas it increased to $450 \mathrm{~m}^{2} \mathrm{~g}^{-1}$ after heat treatment, as would be expected if degradation is followed by the escape of volatile components from a solid matrix occurs [23] (see Chapter 2). Thus, prior to gasification, the humin sample becomes very porous and accessible to reactive gases, in this case steam.

The fresh humin sample has a nominal composition of approximately $65 \mathrm{wt} . \%$ carbon, 4 wt. $\%$ hydrogen and $30 \mathrm{wt} . \%$ oxygen. It also contains traces of sulphur ( $1200 \mathrm{ppm})$. Figure 3.3 shows the compositional changes that occur during heating of the humin sample represented in a typical Van Krevelen diagram. This representation is used normally to follow aromatisation of the substrate but also allows us to measure the extent of de-oxygenation. Starting from $105^{\circ} \mathrm{C}$, a continuous and significant de-oxygenation of the humin is observed with increasing temperature. The corresponding decrease in the $\mathrm{H} / \mathrm{C}$ ratio can be result of dehydration and aromatisation of the sample. Aromatisation is expected to dominate at higher temperatures and we already see an increased amount of aromatic products above $400{ }^{\circ} \mathrm{C}$. The 
sharper change above $600{ }^{\circ} \mathrm{C}$ in the $\mathrm{H} / \mathrm{C}$ ratio is often attributed to dehydrogenation [24]. Thus, owing to de-oxygenation, the humin sample becomes increasingly aromatised before reforming occurs. The solid-state ${ }^{13} \mathrm{C}$ MAS NMR spectrum, shown as inset in Figure 3.3, confirms that only aromatic carbon is present in the sample heated to $700{ }^{\circ} \mathrm{C}$ (the peak at $125 \mathrm{ppm}$ indicates carbon atoms in an aromatic ring).

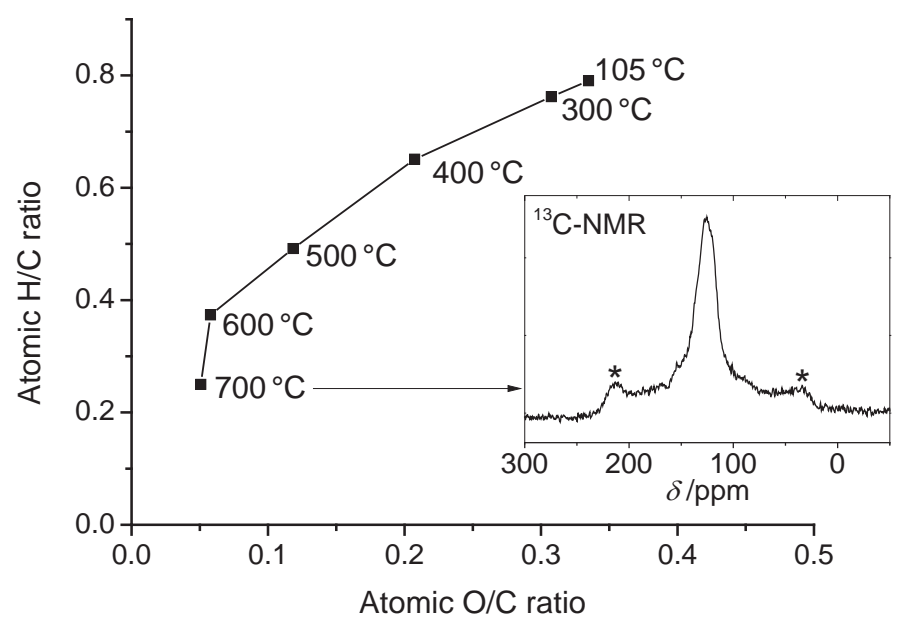

Figure 3.3. Changes in the composition of humin as a function of temperature, details in experimental section; inset graph $-{ }^{13} \mathrm{C}$ CPMAS NMR of humin preheated to $700{ }^{\circ} \mathrm{C}$, * spinning side band (temperature ramp $10{ }^{\circ} \mathrm{C} \cdot \mathrm{min}^{-1}$, in argon saturated water at RT)

The gases that evolved during heating of the humin sample are shown qualitatively in Figure 3.4. The signal for $\mathrm{CO}_{2}$ and $\mathrm{CO}$ starts to increase appreciably above 800 and $850{ }^{\circ} \mathrm{C}$, respectively, whereas the signal for hydrogen increases slightly above $500{ }^{\circ} \mathrm{C}$, levels off at approximately $800{ }^{\circ} \mathrm{C}$ and rises substantially above $850{ }^{\circ} \mathrm{C}$. This indicates a significant increase of steam gasification. The peaks of the $\mathrm{H}_{2}, \mathrm{CO}$ signals at approximately $1050{ }^{\circ} \mathrm{C}$ correspond to the gasification temperature of humin at which the maximum conversion rate occurs. It is possible that gasification takes place at a very low rate between 700 and $850{ }^{\circ} \mathrm{C}$. In summary, under heating in enriched steam gas, humin becomes highly aromatised $(\mathrm{H} / \mathrm{C}$ 0.2 ) and contains some oxygen $(<5-6 \mathrm{wt} . \%)$ before steam reforming occurs. Therefore, the gasification of the remaining humin would resemble the process of char gasification.

The results of the steam reforming of humin, preheated to $750{ }^{\circ} \mathrm{C}$, and performed isothermally at three different temperatures are shown in Figure 3.5. It is clearly seen that at $900{ }^{\circ} \mathrm{C}$ conversion is not complete even after $4 \mathrm{~h}$ time on stream. This is not surprising because the extensive graphitisation of humin during preheating to reach gasification temperatures makes it inert. Steam reforming of such graphitised carbon materials mandates the presence of a catalyst for operation at lower temperatures. 


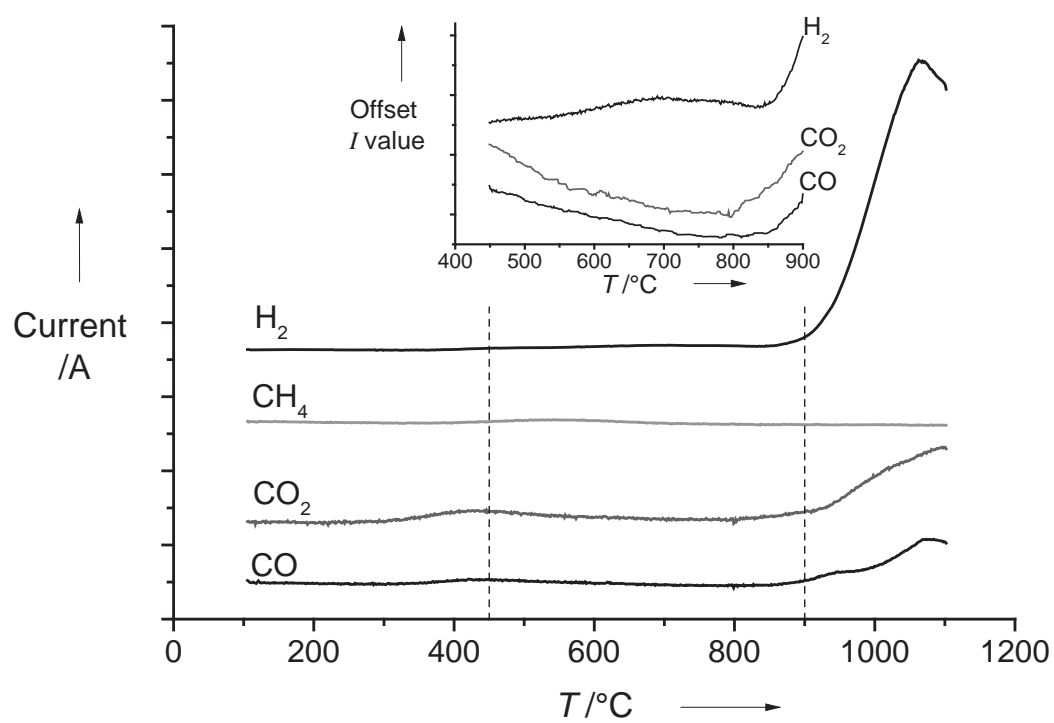

Figure 3.4. Evolution of gaseous products during heating of the humin sample in $\mathrm{H}_{2} \mathrm{O} / \mathrm{Ar}$ followed by mass spectrometry (temperature ramp of $10{ }^{\circ} \mathrm{C} \mathrm{min}^{-1}$ ). Inset graph shows the amplification of gaseous product signals in the temperature range $450-900{ }^{\circ} \mathrm{C}$

\subsubsection{Catalyst screening}

The results of the gasification of humin in the presence of alkali and alkalineearth-based catalysts is summarised in Table 3.1. Gasification rates were determined based on weight changes for the humin samples, dry mixed with the catalysts and in the presence of steam in thermo-gravimetric experiments performed isothermally at $750{ }^{\circ} \mathrm{C}$. The details can be found in the

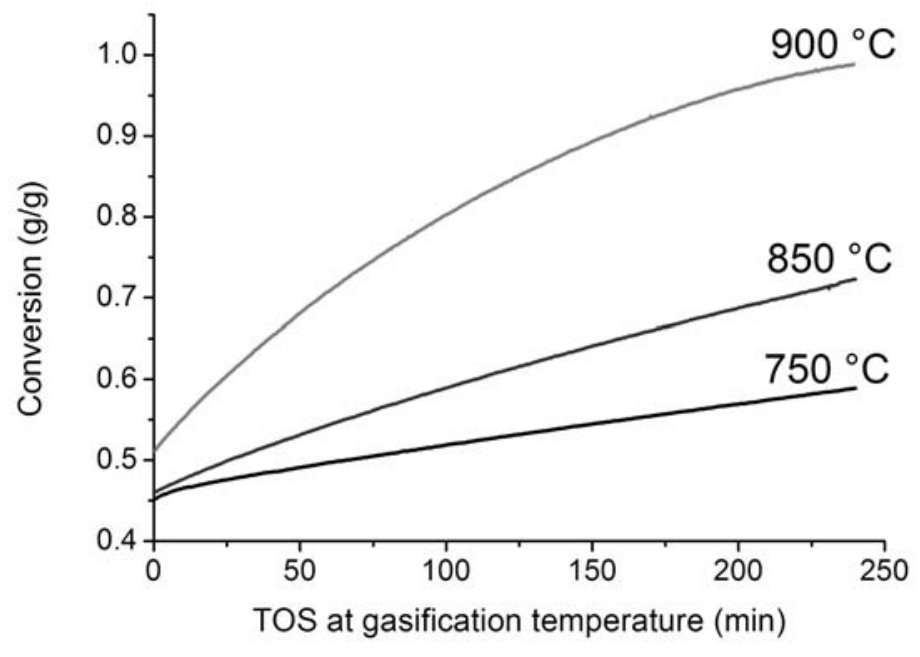

Figure 3.5. Non-catalytic isothermal steam gasification of humin samples at various temperature (sample was preheated to desired temperature at the rate of $10^{\circ} \mathrm{C} \cdot \mathrm{min}^{-}$ $\left.{ }^{1}\right)$

Experimental section.

Gasification rates are given at three conversion levels: $55 \%, 65 \%$ and $78 \%$. In the case of solid-to-gas conversion from batch reactors, the reaction rate is generally a function of 
conversion [25]. In the presence of a catalyst, the rates obtained are much higher than those of the thermal experiments presented in Figure 3.5.

Table 3.1. Gasification rate of Humin at $750{ }^{\circ} \mathrm{C}$. The humin samples were preheated at $750^{\circ} \mathrm{C}$ in steam prior to the experiments.

\begin{tabular}{|c|c|c|c|c|}
\hline \multirow[b]{2}{*}{ Catalyst $^{[\mathrm{a}]}$} & \multicolumn{3}{|c|}{ Gasification rate $\left(10^{-3} \cdot \mathrm{min}^{-1}\right)$} & \multirow[b]{2}{*}{ Time $(\min )^{[\mathrm{c}]}$} \\
\hline & $X=0.55^{[b]}$ & $X=0.65^{[b]}$ & $X=0.78^{[b]}$ & \\
\hline $\mathrm{Na}_{2} \mathrm{CO}_{3}$ & 15.5 & 17 & 17 & 28 \\
\hline $\mathrm{K}_{2} \mathrm{CO}_{3}$ & 5.5 & 7.2 & 9.1 & 77 \\
\hline $\mathrm{Cs}_{2} \mathrm{CO}_{3}$ & 8 & 10.9 & 11.2 & 55 \\
\hline $\mathrm{CaCO}_{3}$ & 2 & 0.65 & $\mathrm{n} \cdot \mathrm{a}^{[\mathrm{d}]}$ & n. $\mathrm{a}^{[\mathrm{d}]}$ \\
\hline Non catalytic & 4.6 & $\mathrm{n} \cdot \mathrm{a}^{[\mathrm{d}]}$ & $\mathrm{n} . \mathrm{a}^{[\mathrm{d}]}$ & $\mathrm{n} . \mathrm{a}^{[\mathrm{d}]}$ \\
\hline \multicolumn{5}{|c|}{$\begin{array}{l}\text { [a] Loading of metal ( } \mathrm{Na}, \mathrm{K}, \mathrm{Cs}, \mathrm{Ca}) \text { is } 0.065 \mathrm{~mol} \mathrm{metal} / 100 \mathrm{~g} \text { humin which } \\
\text { corresponds to loading of } 1.5,2.5,8.66,2.6 \mathrm{wt} . \% \text { metals respectively, [b] X is } \\
\text { accumulative conversion including mass loss during the heating stage as volatiles [c] } \\
\text { Time of stream to achieve conversion } 0.95 \text {. [d] n.a is "not achieved" (final conversion } \\
\text { of humin were below such levels after } 2 \text { hour gasification at } 750^{\circ} \mathrm{C} \text { ) }\end{array}$} \\
\hline
\end{tabular}

It can be seen that at all stages of conversion, $\mathrm{Na}_{2} \mathrm{CO}_{3}$ is appreciably more active than the other catalysts in the gasification of humin. $\mathrm{CaCO}_{3}$ was the least active, even after $2 \mathrm{~h}$, the conversion levels were below $65 \%$. The order of activity is $\mathrm{Na}_{2} \mathrm{CO}_{3}>\mathrm{Cs}_{2} \mathrm{CO}_{3}>\mathrm{K}_{2} \mathrm{CO}_{3}>$ $\mathrm{CaCO}_{3}$. Potassium carbonate shows a lower activity than the other alkali carbonates for humin gasification. This is surprising, as for char steam gasification, which is similar to this, potassium-based catalysts are more active than sodium based catalyst $[18,20]$. Our results do not agree with this, but for humin gasification this is the trend observed experimentally for both carbon dioxide and steam reforming. Based on our own results, this indicates that the chemistry of humin is possibly different from that of char. Further steam reforming experiments were performed with $\mathrm{Na}_{2} \mathrm{CO}_{3}$ as catalyst.

\subsubsection{Influence of sodium carbonate on gasification}

The influence of sodium carbonate on the steam reforming of humin was studied with regard to conversion rates, product and by-product distribution. Figure 3.6 shows the effect of catalyst loading on the gasification rate during isothermal steam reforming. It can be seen that the conversion rate is enhanced tremendously in the presence of $\mathrm{Na}_{2} \mathrm{CO}_{3}$. Compared with thermal gasification under the same conditions, the rate is increased by 10 (with $0.5 \% \mathrm{Na}$ 
addition) to 62 times (with $2.5 \% \mathrm{Na}$ addition). Complete conversion can be achieved in approximately 15 min with the addition of $2.5 \%$ sodium.

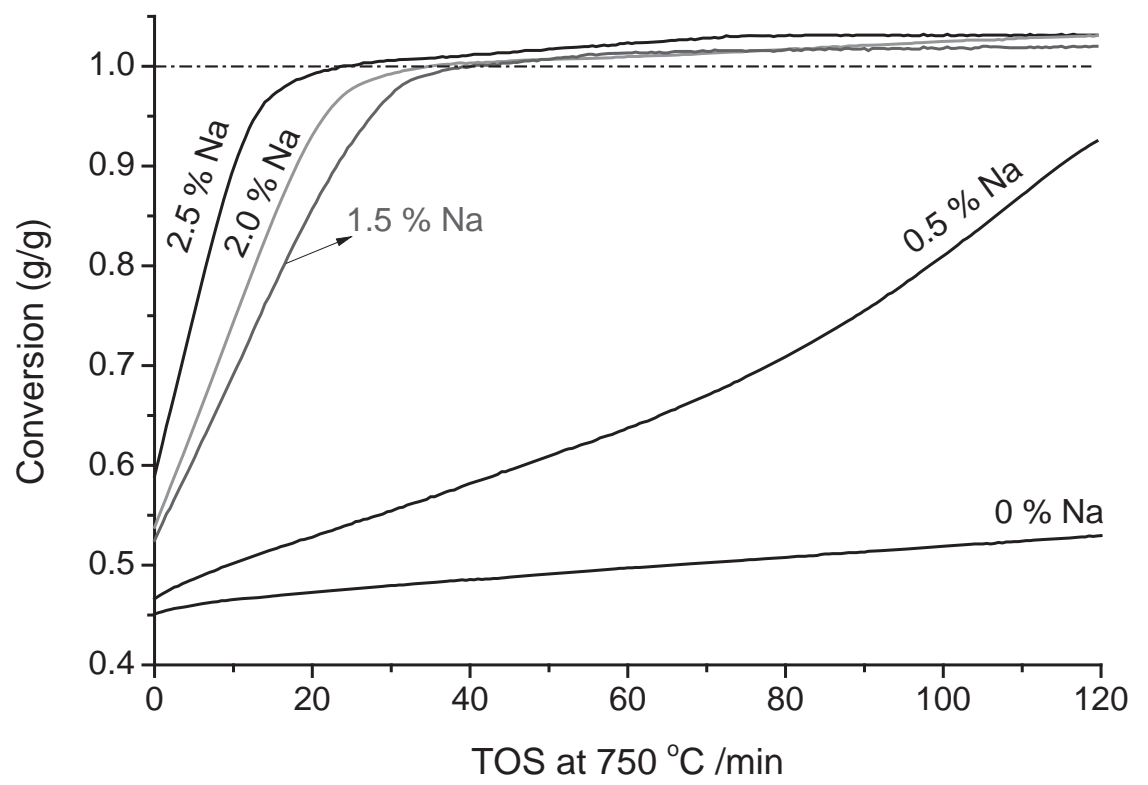

Figure 3.6. Isothermal steam reforming of humin in the presence of $\mathrm{Na}_{2} \mathrm{CO}_{3}$ catalyst at $750{ }^{\circ} \mathrm{C}$; percentages in the legend indicates wt.\% of $\mathrm{Na}$ in the humin sample. $0 \% \mathrm{Na}$ corresponds to thermal gasification

Conversions above $100 \%$ were observed at longer times on stream (Figure 3.6). As the gasification is performed in a thermo-gravimetric analyser (TGA), and the conversion is calculated based on mass loss, this corresponds to a mass loss that is greater than the initial weight of humin. This indicates the loss of sodium carbonate by decomposition or evaporation to the vapour stream. To confirm this, a blank experiment with only sodium carbonate was performed. Under steam-reforming conditions with a water-argon mixture at $750{ }^{\circ} \mathrm{C}$ for 2 hour, approximately $10 \%$ weight loss was observed (see Figure 3.7). However, in the presence of humin, $\mathrm{Na}_{2} \mathrm{CO}_{3}$ hardly remained after the TGA experiments.

To analyse the loss of $\mathrm{Na}_{2} \mathrm{CO}_{3}$ catalyst during the steam gasification of humin, it is important to look at the chemical changes that the catalyst undergoes during gasification. Nagase et. al., [26] postulated a cyclic catalytic scheme for carbon dioxide reforming of carbon. In this scheme, the reaction of carbon with sodium carbonate results in the formation of oxides of sodium [Eq. (1) and Eq. (2)] and CO. The reaction of sodium oxide with $\mathrm{CO}_{2}$ completes the catalytic cycle [Eq. (6)]. We propose that a similar sequence occurs during steam reforming. This is detailed in the following reactions: 


$$
\begin{aligned}
& \mathrm{Na}_{2} \mathrm{CO}_{3}+\mathrm{C} \stackrel{\text { slow }}{\longrightarrow} \mathrm{Na}_{2} \mathrm{O}+2 \mathrm{CO} \\
& 2 \mathrm{Na}_{2} \mathrm{O} \stackrel{\text { rapid }}{\longrightarrow} 2 \mathrm{Na} \text { (gas) }+\mathrm{Na}_{2} \mathrm{O}_{2} \text { (liquid) } \\
& 2 \mathrm{Na}+\mathrm{H}_{2} \mathrm{O} \stackrel{\text { rapid }}{\longrightarrow} \mathrm{Na}_{2} \mathrm{O}+\mathrm{H}_{2} \\
& \mathrm{Na}_{2} \mathrm{O}_{2}+\mathrm{C} \stackrel{\text { fast }}{\longrightarrow} \mathrm{Na}_{2} \mathrm{O}+\mathrm{CO} \\
& \mathrm{H}_{2} \mathrm{O}+\mathrm{CO} \stackrel{\mathrm{CO}}{\longrightarrow} \mathrm{CO}_{2}+\mathrm{H}_{2} \\
& \mathrm{Na}_{2} \mathrm{O}+\mathrm{CO}_{2} \stackrel{\text { slow }}{\longrightarrow} \mathrm{Na}_{2} \mathrm{CO}_{3}
\end{aligned}
$$

$\mathrm{Na}_{2} \mathrm{CO}_{3}$ is thermally stable and decomposes above $850{ }^{\circ} \mathrm{C}$ in argon. During steam reforming, the presence of water and carbon oxides can cause the formation of oxides that may influence its stability. If we look Eq. (6), which describes the formation of $\mathrm{Na}_{2} \mathrm{CO}_{3}$, this requires the presence of $\mathrm{CO}_{2}$ and $\mathrm{CO}_{2}$ should add to the stability of the catalyst. However, the water gas shift (WGS) reaction, the only reaction in which $\mathrm{CO} 2$ is generated, is not favoured by alkali catalysts [15]. Moreover, reactions are performed at elevated temperatures that are not favourable for formation of $\mathrm{CO}_{2}$ by the WGS reaction according to thermodynamics.

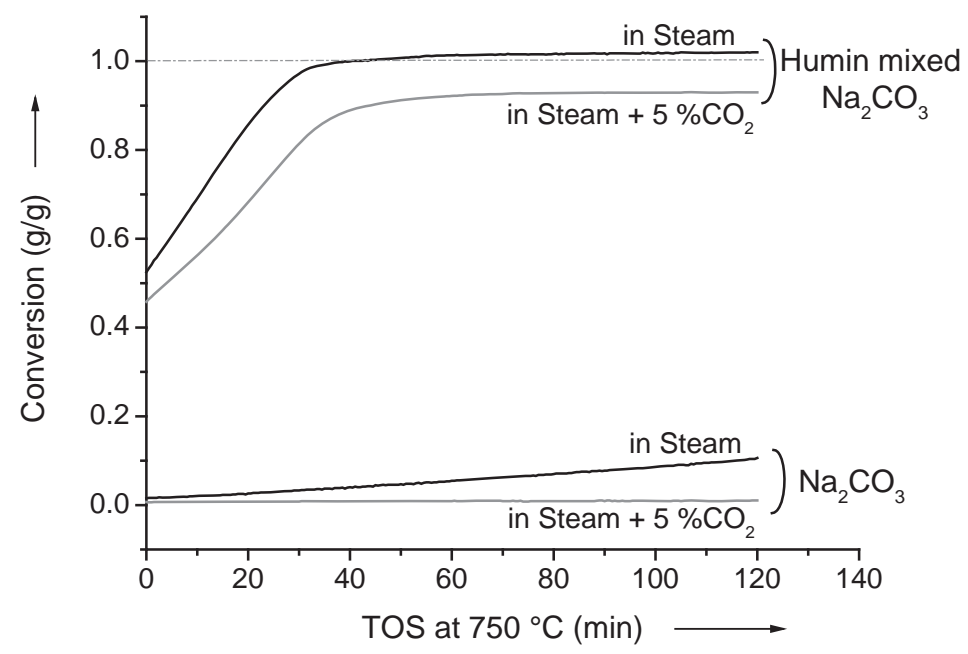

Figure 3.7. The influence of addition of $\mathrm{CO}_{2}$ in steam reforming: humin mixed with $1.5 \mathrm{wt} . \%$ $\mathrm{Na}$ (black line) and sodium carbonate (grey line). Samples are preheated to $750{ }^{\circ} \mathrm{C}$ at temperature ramp of $10^{\circ} \mathrm{C} \cdot \mathrm{min}^{-1}$.

Thus, the addition of $\mathrm{CO}_{2}$ to the feed gas may be a solution to improve the stability of the catalyst, if the above arguments are taken into account. Figure 3.7 shows the influence of the presence of excess $\mathrm{CO}_{2}$ during the gasification experiment. The blank experiment shows that $\mathrm{Na}_{2} \mathrm{CO}_{3}$ is stable even in the presence of steam if $\mathrm{CO}_{2}$ is added. However, in the humin 
gasification experiment, conversions remain below $100 \%$ in the presence of $\mathrm{CO}_{2}$. Such incomplete conversion can be because of the poorer heterogeneous contact between the catalyst and humin and the lower reactivity of $\mathrm{CO}_{2}$ compared to steam. Moreover, in the experiment, the gas composition $\left(\mathrm{CO}_{2} / \mathrm{H}_{2} \mathrm{O}\right.$ partial pressure $\left.\sim 3\right)$ is much richer in $\mathrm{CO}_{2}$ which is a weaker oxidant than steam.

\subsubsection{Products and by-product distribution}

Almost complete conversion of humin can be achieved in the presence of $\mathrm{Na}_{2} \mathrm{CO}_{3}$ catalyst at $750{ }^{\circ} \mathrm{C}$. The addition of carbon dioxide provides stability to the catalyst for continuous operation. Regarding product selectivity, the gas-phase composition during the steam reforming experiment is shown in Figure 3.8. The reforming of humin was performed in a fixed-bed reactor with larger amounts of humin $(35 \mathrm{mg}$ versus $3 \mathrm{mg}$ in the TGA experiments) to allow quantitative analysis of the gas products.

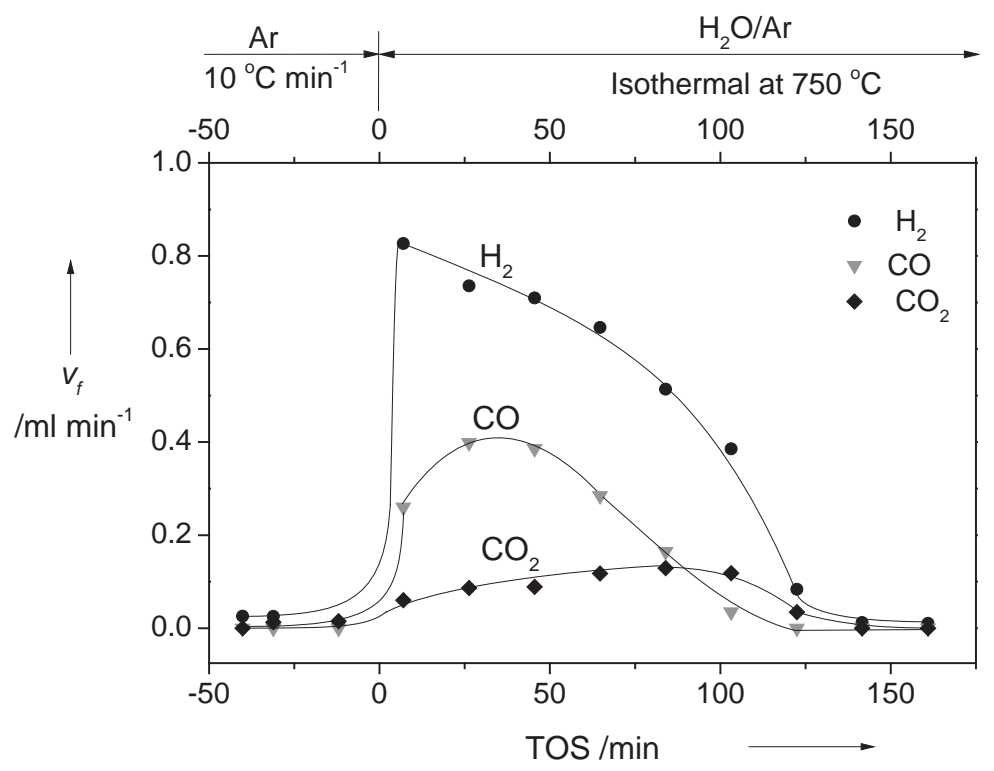

Figure 3.8. Flow rate of gases released during the isothermal steam reforming of preheated humin to $750{ }^{\circ} \mathrm{C}$ : $(\bullet) \mathrm{H}_{2},(\nabla) \mathrm{CO},(\diamond) \mathrm{CO}_{2}$ (heating rate $10{ }^{\circ} \mathrm{C} \cdot \mathrm{min}^{-1}$ in Ar, isothermal reaction at $750{ }^{\circ} \mathrm{C}$ in $\mathrm{Ar}$ saturated $\mathrm{H}_{2} \mathrm{O}$ at RT)

The selectivity to the gas products was estimated by sampling over time (Figure 3.8) as well as by analysing all product gases at the outlet of the reactor collected in a gas balloon (cumulative). These two results are in good agreement with each other ( $4 \%$ difference). Steam reforming of humin with $\mathrm{Na}_{2} \mathrm{CO}_{3}$ catalyst results in $75 \%$ selectivity to $\mathrm{CO}$, and $25 \%$ to $\mathrm{CO}_{2}$ with a $\mathrm{H}_{2} / \mathrm{CO}$ ratio of approximately 2 (results from the analysis of the gas balloon). This corresponds to $81.3 \% \mathrm{H}_{2}$ as compared to thermodynamic equilibrium. We calculated that at 
thermodynamic equilibrium, the selectivity to $\mathrm{CO}_{2}$ is $55.3 \%$ (calculation based on the known elemental composition of the preheated humin), thus the incorporation of a WGS step of the produced $\mathrm{CO}$ is plausible to increase hydrogen yields.

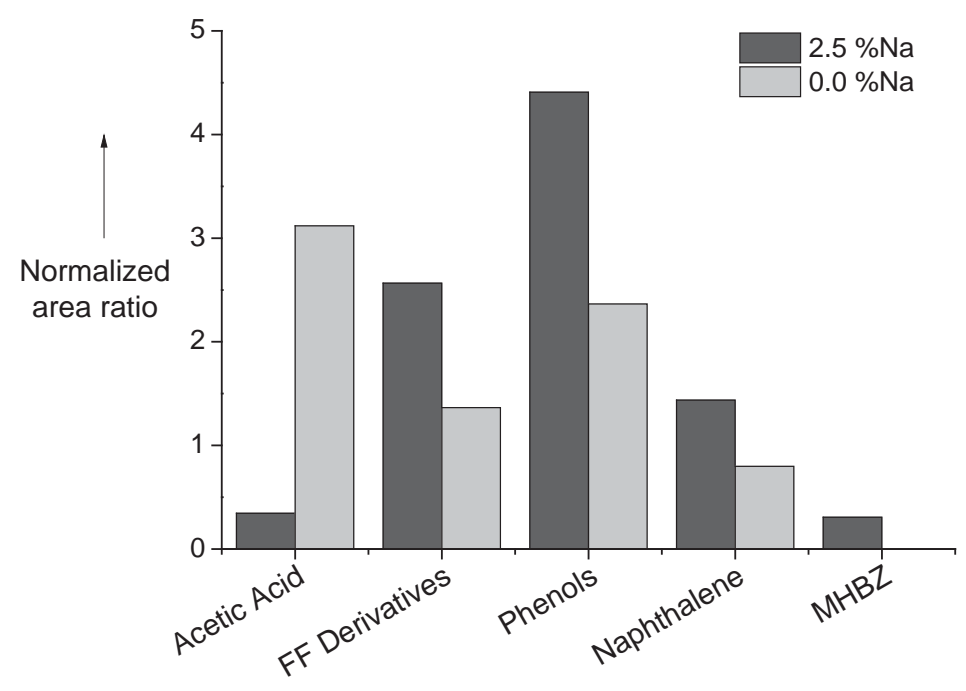

Figure 3.9. Distribution of the components in the condensable fraction identified by GC-MS (FF Derivatives include Furfural, 2-Acetylfuran, HMF and 2-Acetyl-5-methylfuran; Phenols include phenol and cresols; MHBZ is 2-Methyl-5-hydroxybenzofuran). The y axis shows the ratio of the area percentage of each component divided by the area percentage of dimethyl sulfone (internal standard).

As shown in Figure 3.1, the humin sample loses approximately $45 \mathrm{wt} \%$ during the devolatilisation step. The weight loss of humin in the catalytic gasification step is above 40 wt.\% once the gasification reactions start. This loss corresponds to the formation of gases [monitored by (Q-MS) as illustrated in Figure 3.4] and condensable volatiles. Steam reforming of these volatile components is necessary to use the humin feedstock completely and maximise the hydrogen yield. To gain an insight into the nature of the chemicals groups of these volatiles, flash pyrolysis analysis was employed. The advantage of flash pyrolysis is that it offers short residence times, which are typical for solid gasification in gas entrained reactors used in industry. It also prevents secondary reactions (e.g., re-arrangement or recondensation of primary products formed during heating) because of its extremely high heating rate $\left(\sim 925{ }^{\circ} \mathrm{C} \cdot \mathrm{min}^{-1}\right)$ and short residence time. The condensable products were separated and identified by GC-MS. Dimethyl sulfone formed from sulphur in humin samples (known) was the only sulphur containing molecule identified in the condensable fraction, and was selected as the internal reference for different experiments. This was used to calculate the variation of other components. Figure 3.9 illustrates the comparison of condensable products formed during thermal and catalytic gasification with sodium carbonate. A variety of products, 
which included aliphatic acids, furanic and phenolic derivatives, and poly-aromatic components (tars) were observed. The steam reforming of these components is necessary to maximise hydrogen yields.

Acetic acid is known to cause coke formation which leads to the deactivation of catalysts [27-29]. The minimization of acetic acid in the volatiles makes the gas cleaning step less stringent and facilitates the catalytic reforming step. It is clearly seen that the acetic acid yield was reduced significantly $(\sim 90 \%)$ in the case of catalytic reforming. In addition, the yield of furanic and phenolic compounds both increase by approximately $88 \%$. In our group, $\mathrm{ZrO}_{2}$-supported Ni-based catalysts with $\mathrm{K}$ and $\mathrm{La}$ or $\mathrm{CeO}_{2}$ as promoter were developed and show promise for steam reforming of phenol [30]. This catalyst is also stable in acetic acid reforming [28]. However, the presence of furanic components in the volatiles may have an adverse impact. These components contain aldehyde and ketone groups that contribute to coke/char formation by aldol condensation reactions. Experiments with model compounds representing volatiles are will discussed in Chapter 5 and Chapter 6.

\subsubsection{Towards a complete gasification process}

The thermal steam gasification of humin requires an elevated temperature because of the low reactivity of humin. The use of sodium carbonate helps to decrease the gasification temperature and increase the gasification rate. Although complete conversion of humin residue is possible with the use of $\mathrm{Na}_{2} \mathrm{CO}_{3}$, approximately 25 wt.\% carbon (i.e., 45 wt. $\%$

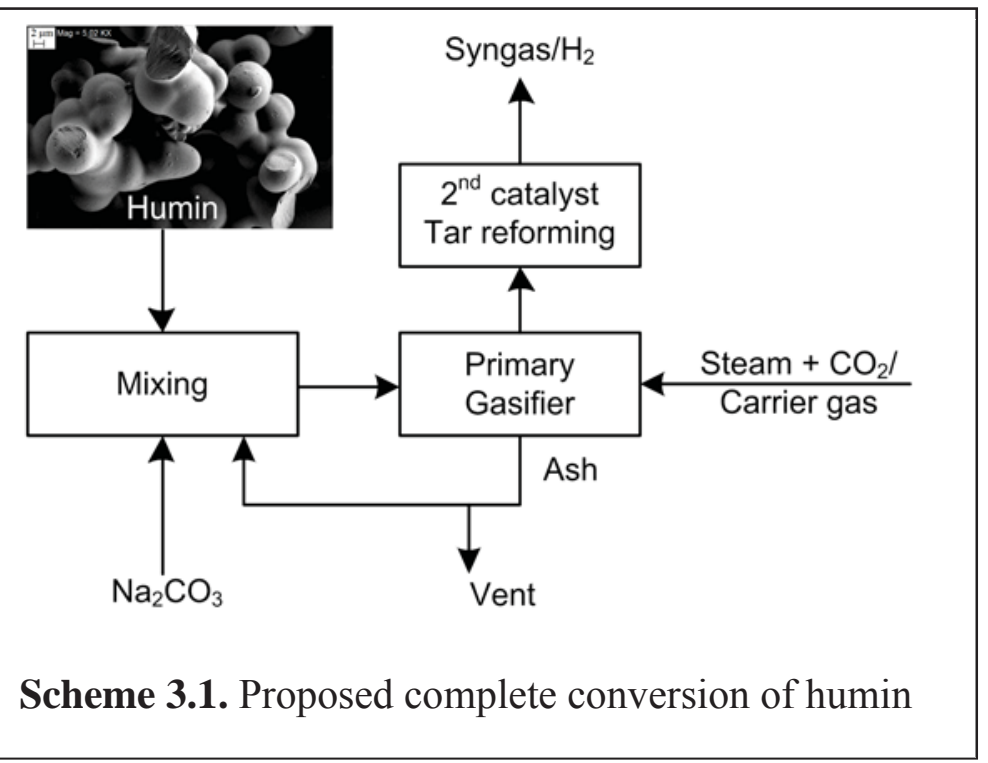
total) is lost as volatiles during heating to the gasification temperature (above $700{ }^{\circ} \mathrm{C}$ ). Therefore, a second catalytic bed for the steam gasification of these volatiles would not only improve hydrogen/syngas yields but also help reduce tar and improve the purity of the product gas. Such a process is illustrated in Scheme 3.1.

In this process, $\mathrm{Na}_{2} \mathrm{CO}_{3}$ and humin are dry mixed. The mixture is then converted in the primary gasifier. Owing to the small particle size of humin, fluidised bed or entrained-flow reactors can be used [3]. The exhaust gas that contains oxygenated volatiles then goes through 
a second catalytic bed, which can be incorporated inside or outside the gasifier (depending on the operating temperature).

As mentioned above, the loss of sodium carbonate during the gasification can be avoided by including dry reforming (using a small amount of $\mathrm{CO}_{2}$ ) in the steam reforming. However, the disadvantage is that some unconverted humin remains as ash, which has high sodium content. Hauserman [31] co-fed wood ash into coal steam reforming, and the reactivity of the substrate was improved substantially. Thus, we suggest that the ash stream can be recycled to minimise the amount of fresh sodium carbonate required. Some ash should be vented to prevent the accumulation of ash over time.

\subsection{Conclusions}

$\mathrm{Na}_{2} \mathrm{CO}_{3}$ is appreciably more active than the other alkali- and alkaline-earth-based catalyst studied. $\mathrm{Na}_{2} \mathrm{CO}_{3}$ is thermally stable. However, during steam reforming, the presence of water and carbon oxides can cause the formation of sodium oxides that may influence its stability. The addition of carbon dioxide provides stability to the catalyst by enhancing the formation of carbonate from the oxide phase.

Humin becomes highly aromatised and undergoes extensive de-oxygenation during heating to steam reforming temperatures and the residue resembles char. The humin sample loses approximately $45 \mathrm{wt} . \%$ through de-volatilisation during heating. The steam reforming of these volatile components is necessary to use the humin feed-stock completely, and maximise hydrogen yield. The presence of $\mathrm{Na} 2 \mathrm{CO} 3$ improves the gasification rate tremendously, thus it also enable the reaction in milder condition (viz. lower temperature) thus reducing the energy consumption.

\section{Bibliography}

[1] T.J. Crowley, Causes of climate change over the past 1000 years, Science, 289 (2000) 270-277.

[2] J.H. Clark, F.E.I. Deswarte, T.J. Farmer, The integration of green chemistry into future biorefineries, Biofuel Bioprod Bior, 3 (2009) 72-90.

[3] L.H. Zhang, C.B. Xu, P. Champagne, Overview of recent advances in thermo-chemical conversion of biomass, Energy Conversion and Management, 51 (2010) 969-982. 
[4] A.J. Ragauskas, C.K. Williams, B.H. Davison, G. Britovsek, J. Cairney, C.A. Eckert, W.J. Frederick, Jr., J.P. Hallett, D.J. Leak, C.L. Liotta, J.R. Mielenz, R. Murphy, R. Templer, T. Tschaplinski, The path forward for biofuels and biomaterials, Science, 311 (2006) 484-489.

[5] B.F.M. Kuster, The influence of water concentration on the dehydration of d-fructose, Carbohydrate research, 54 (1977) 177-183.

[6] J.J. Bozell, G.R. Petersen, Technology development for the production of biobased products from biorefinery carbohydrates - the US Department of Energy's "Top 10" revisited, Green Chemistry, 12 (2010) 539.

[7] R.J. Van Putten, J.C. Van Der Waal, E. De Jong, C.B. Rasrendra, H.J. Heeres, J.G. De Vries, Hydroxymethylfurfural, a versatile platform chemical made from renewable resources, Chemical reviews, 113 (2013) 1499-1597.

[8] B. Girisuta, L.P.B.M. Janssen, H.J. Heeres, Kinetic Study on the Acid-Catalyzed Hydrolysis of Cellulose to Levulinic Acid, Industrial \& Engineering Chemistry Research, 46 (2007) 1696-1708.

[9] S.W. Fitzpatrick, US5608105 - production of levulinic acid from carbohydrate containing materials, in: U.S. Patent (Ed.), Biofine Incorporated, Wilmington, Del., United States, 1997.

[10] R. Weingarten, W.C. Conner, G.W. Huber, Production of levulinic acid from cellulose by hydrothermal decomposition combined with aqueous phase dehydration with a solid acid catalyst, Energy \& Environmental Science, 5 (2012) 7559-7574.

[11] V.V. Ordomsky, V.L. Sushkevich, J.C. Schouten, J. van der Schaaf, T.A. Nijhuis, Glucose dehydration to 5-hydroxymethylfurfural over phosphate catalysts, Journal of Catalysis, 300 (2013) 37-46.

[12] B. Girisuta, L.P.B.M. Janssen, H.J. Heeres, A kinetic study on the decomposition of 5hydroxymethylfurfural into levulinic acid, Green Chemistry, 8 (2006) 701.

[13] X. Hu, C. Lievens, A. Larcher, C.Z. Li, Reaction pathways of glucose during esterification: effects of reaction parameters on the formation of humin type polymers, Bioresource technology, 102 (2011) 10104-10113.

[14] I. van Zandvoort, Y. Wang, C.B. Rasrendra, E.R. van Eck, P.C. Bruijnincx, H.J. Heeres, B.M. Weckhuysen, Formation, Molecular Structure, and Morphology of Humins in Biomass Conversion: Influence of Feedstock and Processing Conditions, ChemSusChem, (2013).

[15] D. Sutton, B. Kelleher, J.R.H. Ross, Review of literature on catalysts for biomass gasification, Fuel Processing Technology, 73 (2001) 155-173.

[16] D. Dayton, A review of the literature on catalytic biomass tar destruction, in: Milestone Completion Report, National Renewable Energy Laboratory, 2002.

[17] M.M. Yung, W.S. Jablonski, K.A. Magrini-Bair, Review of Catalytic Conditioning of Biomass-Derived Syngas, Energy \& Fuels, 23 (2009) 1874-1887. 
[18] Z.L. Liu, H.H. Zhu, Steam Gasification of Coal Char Using Alkali and Alkaline-Earth Metal-Catalysts, Fuel, 65 (1986) 1334-1338.

[19] R.C. Brown, Q. Liu, G. Norton, Catalytic effects observed during the co-gasification of coal and switchgrass, Biomass Bioenerg, 18 (2000) 499-506.

[20] D.W. Mckee, C.L. Spiro, P.G. Kosky, E.J. Lamby, Catalysis of Coal Char Gasification by Alkali-Metal Salts, Fuel, 62 (1983) 217-220.

[21] T.S. Nguyen, M. Zabeti, L. Lefferts, G. Brem, K. Seshan, Catalytic upgrading of biomass pyrolysis vapours using faujasite zeolite catalysts, Biomass and Bioenergy, 48 (2013) 100110.

[22] R.M. Navarro, M.A. Pena, J.L. Fierro, Hydrogen production reactions from carbon feedstocks: fossil fuels and biomass, Chemical reviews, 107 (2007) 3952-3991.

[23] T.M.C. Hoang, E.R.H. Van Eck, W.P. Bula, J.G.E. Gardeniers, L. Lefferts, K. Seshan, Humin based by products from bioprocessing as potential carbonaceous source for synthesis gas production, Green Chemistry, (submitted) (2014).

[24] R.K. Sharma, J.B. Wooten, V.L. Baliga, M.R. Hajaligol, Characterization of chars from biomass-derived materials: pectin chars, Fuel, 80 (2001) 1825-1836.

[25] C. Di Blasi, Combustion and gasification rates of lignocellulosic chars, Progress in Energy and Combustion Science, 35 (2009) 121-140.

[26] K. Nagase, T. Shimodaira, M. Itoh, Y. Zheng, Kinetics and mechanisms of the reverse Boudouard reaction over metal carbonates in connection with the reactions of solid carbon with the metal carbonates, Physical Chemistry Chemical Physics, 1 (1999) 5659-5664.

[27] K. Takanabe, K. Aika, K. Seshan, L. Lefferts, Catalyst deactivation during steam reforming of acetic acid over Pt/ZrO2, Chemical Engineering Journal, 120 (2006) 133-137.

[28] B. Matas Güell, I.M. Torres da Silva, K. Seshan, L. Lefferts, Sustainable route to hydrogen - Design of stable catalysts for the steam gasification of biomass related oxygenates, Applied Catalysis B: Environmental, 88 (2009) 59-65.

[29] L. An, C. Dong, Y. Yang, J. Zhang, L. He, The influence of Ni loading on coke formation in steam reforming of acetic acid, Renewable Energy, 36 (2011) 930-935.

[30] B. Matas Güell, I.V. Babich, L. Lefferts, K. Seshan, Steam reforming of phenol over Nibased catalysts - A comparative study, Applied Catalysis B: Environmental, 106 (2011) 280286.

[31] W.B. Hauserman, High-Yield Hydrogen-Production by Catalytic Gasification of Coal or Biomass, International Journal of Hydrogen Energy, 19 (1994) 413-419. 
Appendix 3

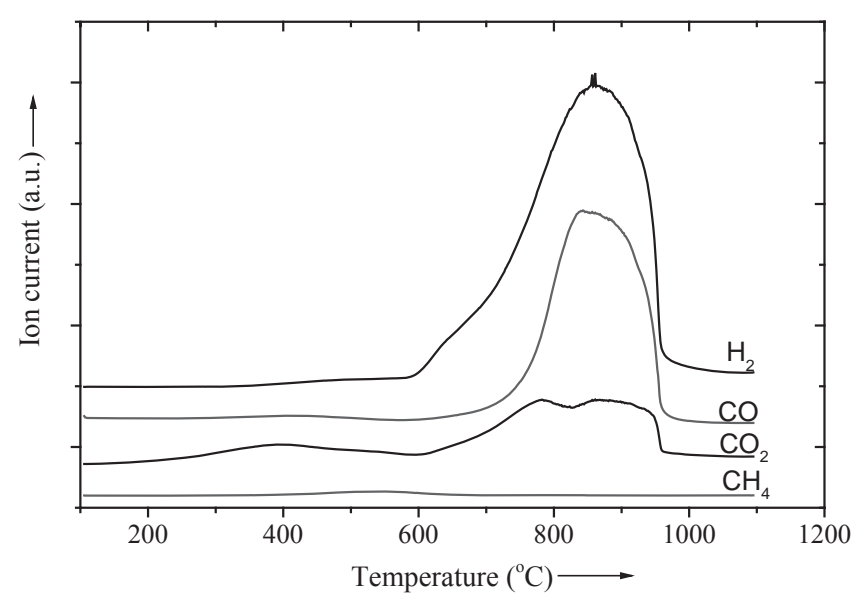

Figure A.3.1. Evolution of gaseous products during steam reforming of the humin sample in presence of $\mathrm{Na}_{2} \mathrm{CO}_{3}(1.5 \% \mathrm{Na})$ followed by mass spectrometry (Ar saturated with $\mathrm{H}_{2} \mathrm{O}$, temperature ramp of $\left.10^{\circ} \mathrm{C} \cdot \mathrm{min}^{-1}\right)$

Figure A.3.1 indicates that the onset of catalytic steam reforming reaction of humin occurs at $\sim 600{ }^{\circ} \mathrm{C}$ which is much lower than that of non-catalytic one, $\sim 800^{\circ} \mathrm{C}$ (from Figure 3.4) 


\title{
4
}

\section{Catalytic dry reforming of humin with $\mathrm{Na}_{2} \mathrm{CO}_{3}$ as catalyst}

\begin{abstract}
Kinetics study on dry-reforming of humin was performed with different humin samples in the presence of sodium carbonate. The conversion rate remained almost constant in a wide range of conversion degree and was linearly proportional to the amounts of sodium carbonate used. Dry reforming reactions of humin in the presence of sodium carbonate resemble to the bulk reaction. The nature of sodium catalyst at gasification temperature was studied by using labelled $\mathrm{Na}_{2}{ }^{13} \mathrm{CO}_{3}$ and ${ }^{23} \mathrm{Na}$ MAS-NMR.
\end{abstract}




\subsection{Introduction}

Thermal gasification of humin (in $\mathrm{CO}_{2}$ or steam) was demonstrated in previous chapters. Due to the de-volatilisation that occurs during heating to gasification temperatures, humin becomes more and more aromatised/graphitised. At the gasification temperatures, humin resembles bio-char and show low reactivity towards non-catalytic dry $\left(\mathrm{CO}_{2}\right)$ as well as steam reforming. In chapter 3, various alkali metal carbonates and $\mathrm{CaCO}_{3}$ were screened as possible catalysts for steam reforming and $\mathrm{Na}_{2} \mathrm{CO}_{3}$ showed the highest activity [1]. Although complete conversion can be achieved via steam reforming of humin with $\mathrm{Na}_{2} \mathrm{CO}_{3}$, loss of catalyst into gas phase was observed due to conversion of $\mathrm{Na}_{2} \mathrm{CO}_{3}$ to more volatile species. Adding small amounts of $\mathrm{CO}_{2}$ in the reactive gas feed stream improved the stability of $\mathrm{Na}_{2} \mathrm{CO}_{3}$ catalysts. Thus the gasification process is a combination of steam reforming and $\mathrm{CO}_{2}$ reforming. It is, therefore, essential to understand the details of the catalytic gasification in $\mathrm{CO}_{2}$. A kinetics study of the reaction can also provide useful knowledge for industrial application since it can cover wider range of reactive gas compositions as well as generate the necessary kinetic parameters. It can help additionally to predict the behaviour of humin during steam reforming in the presence of carbon dioxide.

In order to minimise the influence of sugar residues on the dry or steam reforming, purified humin samples were employed in earlier investigations reported in chapters $2 \& 3$. In this chapter we have also included non-purified samples. This is to take care of the fact that purification (Soxhlet extraction in water for 24 hour) is time and energy consuming. Moreover, the recovery the sugar residue in diluted solution is challenging and costly.

In this chapter, kinetics of $\mathrm{CO}_{2}$ reforming of the pristine humin (without purification) is included and compared with results on the clean humin. Furthermore, insight into the behaviour or transformation of sodium carbonate is initiated by using isotopic labelling of $\mathrm{Na}_{2} \mathrm{CO}_{3}$ for dry reforming as well as for characterisation using ${ }^{23} \mathrm{Na}$ MAS-NMR.

\subsection{Experimental}

All chemicals used in this study were analytical grade, purchased from Sigma-Aldrich and used without further purification.

Two humin samples, pristine and after purification (Soxhlet extraction in water for 24 hours) were used and denoted as HG1 and HG2. The latter sample was used for the kinetics experiments (both dry and steam reforming - in chapter 2 and 3). $\mathrm{HG} 1$ and $\mathrm{Na}_{2} \mathrm{CO}_{3}(\mathrm{Na} / \mathrm{HG} 1$ $\sim 1.5 / 100 \mathrm{w} / \mathrm{w}$ ) were ball-milled together in $\mathrm{ZrO}_{2}$ coated jar using frequency of $20 \mathrm{~Hz}$ for 15 minute. In other cases, $\mathrm{Na}_{2}{ }^{13} \mathrm{CO}_{3}\left({ }^{13} \mathrm{C} 99 \%\right.$ molar $)$ and $\mathrm{HG} 1$ were mixed together with 
mortar and pestle. HG2 was only used for investigating the influence of the catalyst loading on the reaction rate. Various amounts of $\mathrm{Na}(\mathrm{Na} / \mathrm{Humin} \sim 0.5-2.5 \mathrm{wt} \%)$ were mixed with HG2 using a Fluxana mixer (MU-K-Mixer_50 Hz) for $\sim 20$ minutes which mainly mixes the powders together by shaking, albeit in the presence of two small plastic balls.

Catalytic dry reforming of humin was performed in a Mettler Toledo thermo gravimetric analyser (TGA/SDTA/851e). Gas supply to the TGA chamber included two streams: protective gas stream using Ar which is flown to the sides to the crucible and reactive gas stream containing $\mathrm{CO}_{2}$ and Ar flowing in adjacent to the top of the crucible. The inlet of a mass spectrometer (Balzer QMS 200F) was inserted next to the outlet valve of the oven to monitor the gas evolution during TGA analysis. Mixture of humin with $\mathrm{Na}_{2} \mathrm{CO}_{3}$ (initial weight of $2-3 \mathrm{mg}$ ) was placed in an alpha alumina crucible (volume of $70 \mu \mathrm{l}$ ) and dried in situ at $105^{\circ} \mathrm{C}$ (heating from $25^{\circ} \mathrm{C}$ at the ramp of $10{ }^{\circ} \mathrm{C} . \mathrm{min}^{-1}$ ). After that the furnace was raised to reforming temperatures $\left(725-775{ }^{\circ} \mathrm{C}\right)$ and kept there for $1-5$ hours before cooling to room temperature.

${ }^{23} \mathrm{Na}$ MAS NMR spectra of humin- $\mathrm{Na}_{2} \mathrm{CO}_{3}$ mixtures were recorded with a $14.1 \mathrm{~T}$ Varian VNMRS system at magic angle spinning (MAS) frequency of $20 \mathrm{kHz}$ using $3.2 \mathrm{~mm}$ MAS probe. The spectra were referenced to $\mathrm{NaCl}$.

All conversion values used in this study are cumulative and calculated as following:

$$
\begin{aligned}
& \text { Conversion }\left(\mathrm{X}_{\mathrm{i}}\right)=\frac{\mathrm{m}_{0}-\mathrm{m}_{\mathrm{i}}}{\mathrm{m}_{0}-\mathrm{m}_{\mathrm{salt}}} \quad(\mathrm{w} / \mathrm{w}) \\
& \text { Conversion rate }=\frac{\delta \mathrm{X}_{\mathrm{i}}}{\delta \mathrm{t}}\left(\mathrm{min}^{-1}\right)
\end{aligned}
$$

Where: $\mathrm{m}_{0}, \mathrm{~m}_{\text {salt }}, \mathrm{m}_{\mathrm{i}}$ are mass of humin sample after in situ drying at $105^{\circ} \mathrm{C}$ for 1 hour, mass of $\mathrm{Na}_{2} \mathrm{CO}_{3}$ in the mixture and humin residue at the measuring point of interest, respectively; $\mathrm{X}_{\mathrm{i}}$ is conversion at this point. The conversion rate is the slope of the conversion $v s$. TOS at that conversion level.

\subsection{Results and discussion}

\subsubsection{Kinetics dry reforming}

The influence of gasification temperatures on the conversion of humin (to gas products) is illustrated in Figure 4.1. It can be seen that the conversion of humin in the 

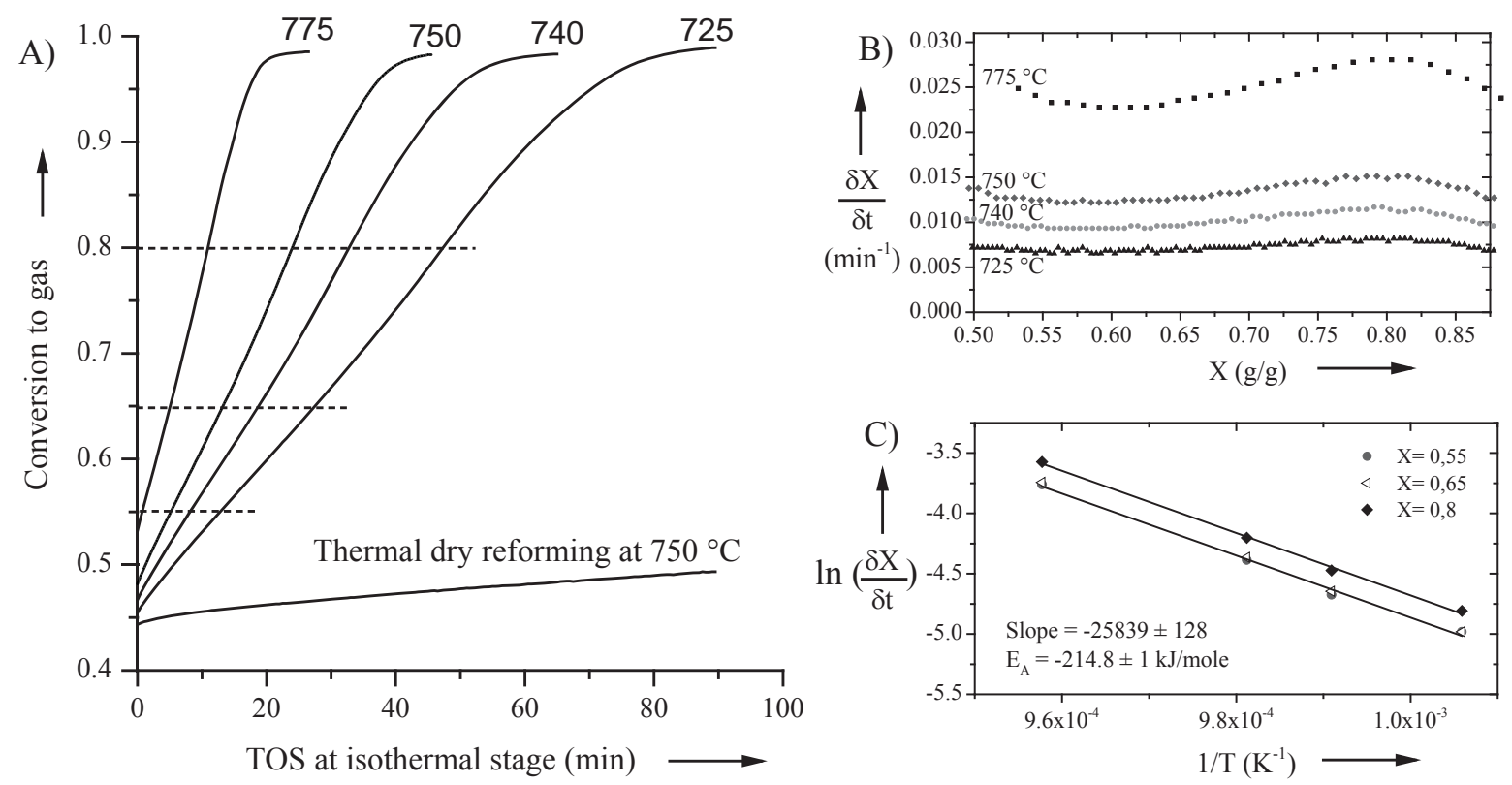

Figure 4.1. Isothermal conversion of $\mathrm{HG1}$ ball-milled with $\mathrm{Na}_{2} \mathrm{CO}_{3}$ at various dry reforming temperatures (A), conversion rate vs. conversion (B) and the Arrhenius plot at conversion of $0.55(\bullet), 0.65(\triangleleft)$ and $0.8(\diamond)$ respectively. Heating rate $10{ }^{\circ} \mathrm{C}$ . $\mathrm{min}^{-1}$; gas flowrate $\left(\mathrm{CO}_{2}+\mathrm{Ar}\right)_{\text {reactive }} / \mathrm{Ar}_{\text {protective }}=(40+20) / 40 \mathrm{ml} \cdot \mathrm{min}^{-1} ; \mathrm{P}=1 \mathrm{~atm}$; $\mathrm{Na} /$ Humin $\sim 1.5$ wt. $\%$

presence of $\mathrm{Na}_{2} \mathrm{CO}_{3}$ is improved tremendously compared with thermal gasification. In addition, the conversion is linearly proportional to the reaction time over a wide range of conversion levels which means constant conversion rate. Generally, in biomass gasification, the morphology, texture and structure of biomass residue strongly depends on the degree of conversion, thus the reaction rate can vary over the conversion range [2]. However, in this case both reaction rate (Figure 4.1-B) and the activation energy of dry reforming reaction estimated from Arrhenius plot (Figure 4.1-C) are almost constant in the conversion range from 0.45 (initial conversion value of dry reforming stage) to $\sim 0.9$. A linear relationship between conversion and reaction time could

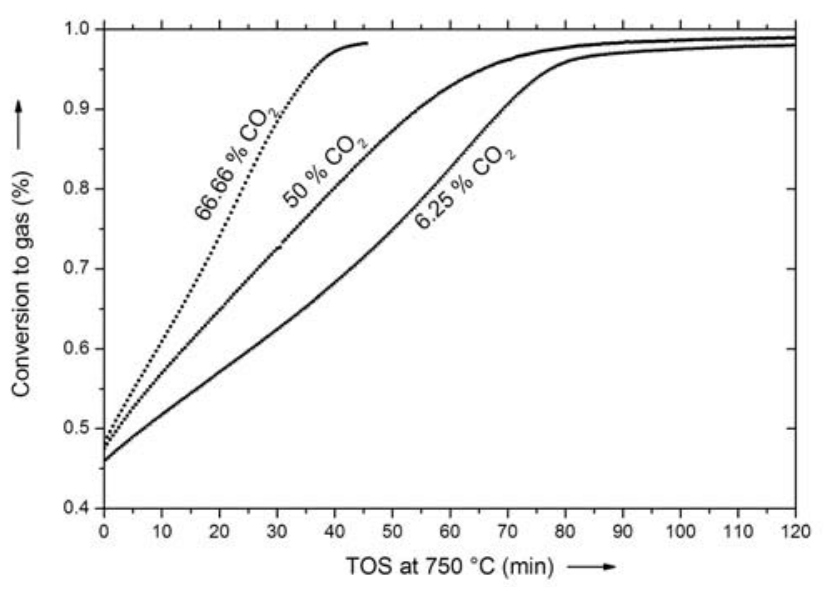

Figure 4.2. The influence of $\mathrm{CO}_{2}$ concentration in reactive gas stream on the conversion of humin 
also be observed when reactive gas composition changed (illustrated in Figure 4.2) or with variation in catalyst loading (discussed in the next section). Therefore, the catalytic dry reforming of humin in presence of $\mathrm{Na}_{2} \mathrm{CO}_{3}$ proceeds evenly and resembles bulk reaction.

The activation energy of $214 \pm 1 \mathrm{~kJ} \mathrm{~mol}^{-1}$ for dry reforming in the presence of $\mathrm{Na}_{2} \mathrm{CO}_{3}$ (calculated from Arrhenius plot, Figure 4.1-C) is in the same range for dry

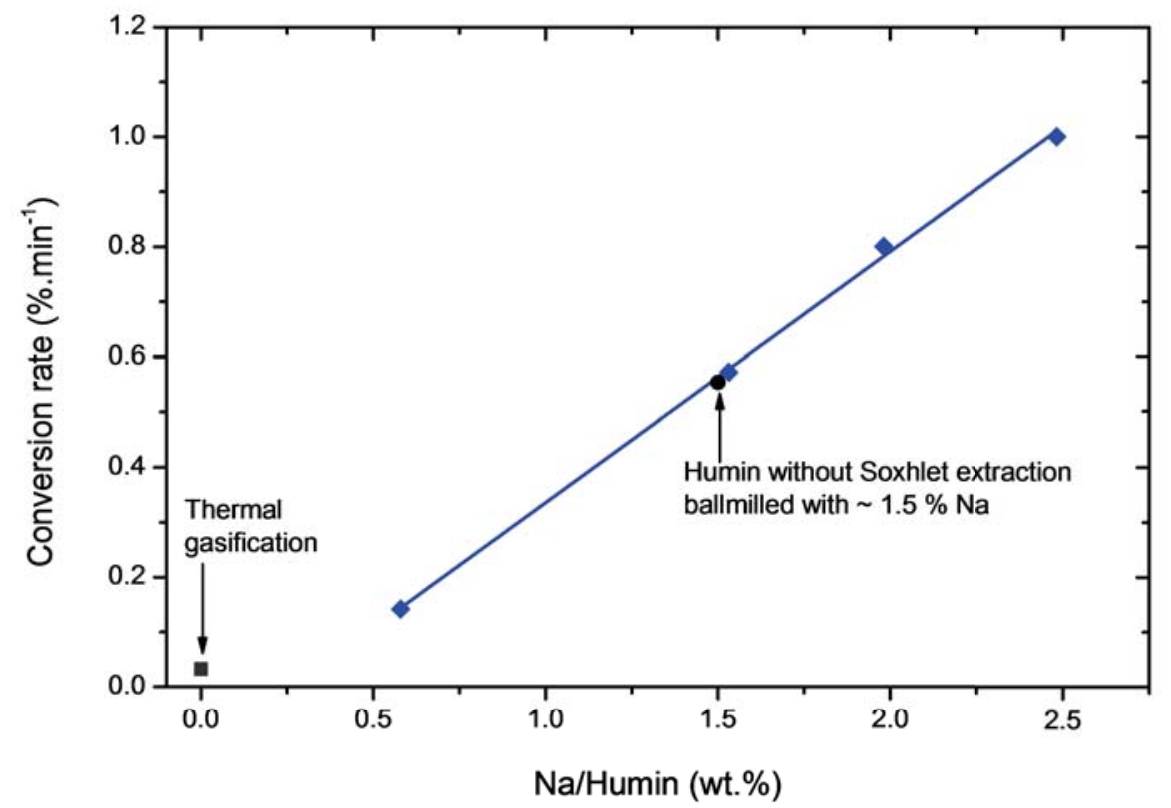

Figure 4.3. Influence of sodium loading, $\mathrm{T}=700{ }^{\circ} \mathrm{C}$, reactive gas: $\mathrm{CO}_{2} / \mathrm{Ar}=5 \mathrm{ml} \cdot \mathrm{min}^{-1} / 75$ ml.min ${ }^{-1}$, protective gas $20 \mathrm{ml} \cdot \mathrm{min}^{-1}$. HG2 (»), HG1 ball-milled with $1.5 \mathrm{wt} . \% \mathrm{Na}(\bullet)$, thermal dry reforming $(\square)$

reforming of bio-derived char as summarised in the review on combustion and gasification of char by Blasi [2].

Figure 4.3 shows the influence of sodium loading on the conversion rate. It should be remarked that purified humin is used for this data set. Improvement of conversion rate due to presence of $\mathrm{Na}_{2} \mathrm{CO}_{3}$ is confirmed again. Compared to thermal reforming under the same conditions, the conversion rate is improved substantially. In the range from 0.5 to $2.5 \mathrm{wt} . \%$, the conversion rate is proportional to the sodium loading. The slope derived from the linear fitting is $\sim 0.45$ which means $\sim 0.45$ wt.\% humin can be converted with 1 wt.\% $\mathrm{Na}$ increment. Further, the conversion rate of pristine humin ball-milled with $\mathrm{Na}_{2} \mathrm{CO}_{3}$ also falls in the same curve (one experimental 
point). Therefore, we expect similar properties of these two humin samples for dry reforming reaction.

\subsubsection{Consideration of reaction pathway in catalytic dry reforming of humin with $\mathrm{Na}_{2} \mathrm{CO}_{3}$ catalyst}

The use and influence of alkali carbonate catalysts on gasification of carbon rich materials (e.g., coal, char, graphite) has been known for a long time. Albeit a lot of attempts, the actual reaction pathways and active species/sites in the catalytic reactions are still debated [3-6]. Different reaction mechanisms proposed in the literature critically reviewed by Moulijn and co-workers [5] are represented in Figure 4.4. Basically, the suggested reaction schemes involve cyclic transformations between carbonate and oxidic/metal phases of the catalyst. Accordingly, Moulijn et al suggested a sequence, supported by their own experimental study, of $\mathrm{CO}_{2}$ reforming of coal catalysed by potassium, involving cyclic reaction of oxidic potassium species $\left(\mathrm{K}_{\mathrm{x}} \mathrm{O}_{\mathrm{y}} / \mathrm{K}_{\mathrm{x}} \mathrm{O}_{\mathrm{y}+1}\right)$. However, the actual chemical formula/structures of these active species was not resolved yet, and many oxide forms of potassium (e.g., $\mathrm{K}_{2} \mathrm{O}, \mathrm{K}_{2} \mathrm{O}_{2}, \mathrm{~K}_{2} \mathrm{O}_{3}$ except $\mathrm{K}_{2} \mathrm{CO}_{3}$ ) were suggested to be possible. On the other hand, the mechanism proposed by McKee [4, 7], discussed below, is acknowledged and mentioned in many works [3, 8]. This mechanism proposed by McKee consists of three elementary reactions:

$$
\begin{aligned}
& \mathrm{M}_{2} \mathrm{CO}_{3}+2 \mathrm{C}=2 \mathrm{M}+3 \mathrm{CO} \\
& 2 \mathrm{M}+\mathrm{CO}_{2}=\mathrm{M}_{2} \mathrm{O}+\mathrm{CO} \\
& \mathrm{M}_{2} \mathrm{O}+\mathrm{CO}_{2}=\mathrm{M}_{2} \mathrm{CO}_{3}
\end{aligned}
$$

According to this mechanism, carbon (or humin) would react directly with $\mathrm{Na}_{2} \mathrm{CO}_{3}$ via reaction (1) to form $\mathrm{Na}$ metal and $\mathrm{CO}$. However, $\mathrm{Na}_{2} \mathrm{CO}_{3}$ is stable in $\mathrm{CO}_{2}$ rich atmospheres [1]. It was shown in chapter 3 that almost no weight loss of $\mathrm{Na}_{2} \mathrm{CO}_{3}$ was observed during $2 \mathrm{~h}$ TOS in mixture of 5 vol. $\% \mathrm{CO}_{2} /$ steam enriched Ar at $750{ }^{\circ} \mathrm{C}$. Therefore, during dry reforming conditions, $\mathrm{Na}_{2} \mathrm{CO}_{3}$ would be expected to stay in solid phase, making the contact between active catalyst species and $\mathrm{C}$ difficult. In this case, the dry reforming should proceed via solid-solid reactions. Therefore, the reactions rate should depend strongly on particle size (both humin and $\mathrm{Na}_{2} \mathrm{CO}_{3}$ ), dispersion of $\mathrm{Na}_{2} \mathrm{CO}_{3}$ homogeneously in the humin matrix. In case of the sublimation of alkali metal (here $\mathrm{Na}$, which is susceptible to sublimation at the gasification temperatures), redistribution of sodium species is possible. Therefore, the reaction rate can vary 


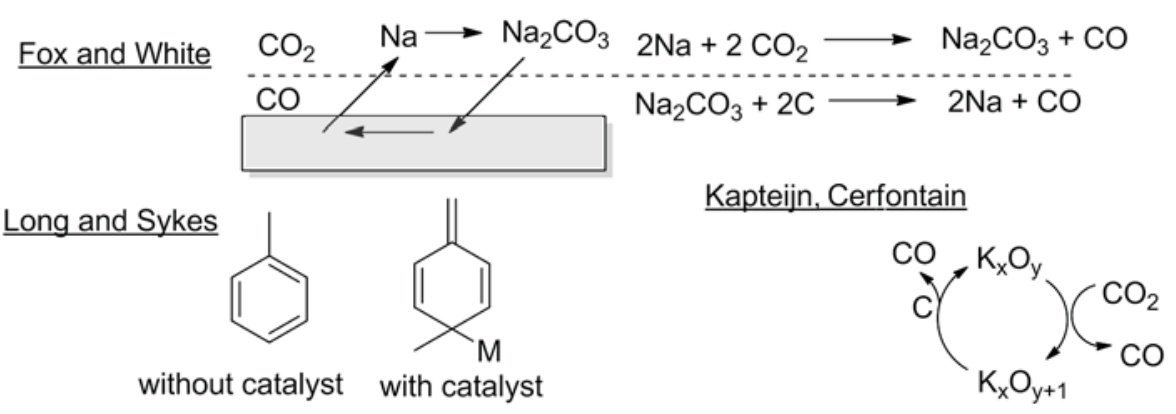

McKee
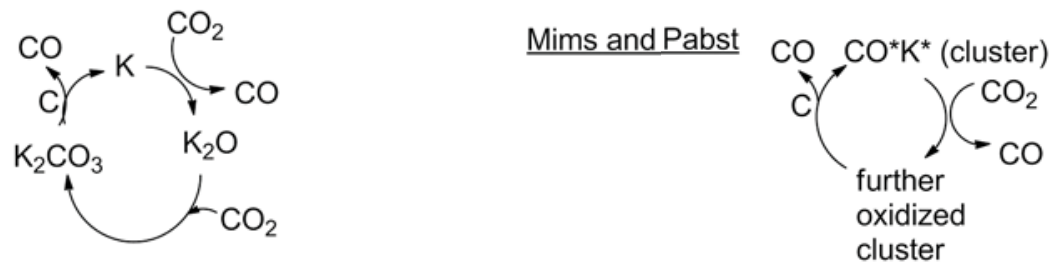

Yokoyama

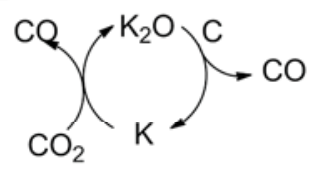

$\underline{\text { Spiro }}$

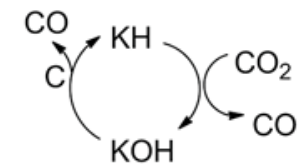

Wood

$\underline{\text { Wen }}$
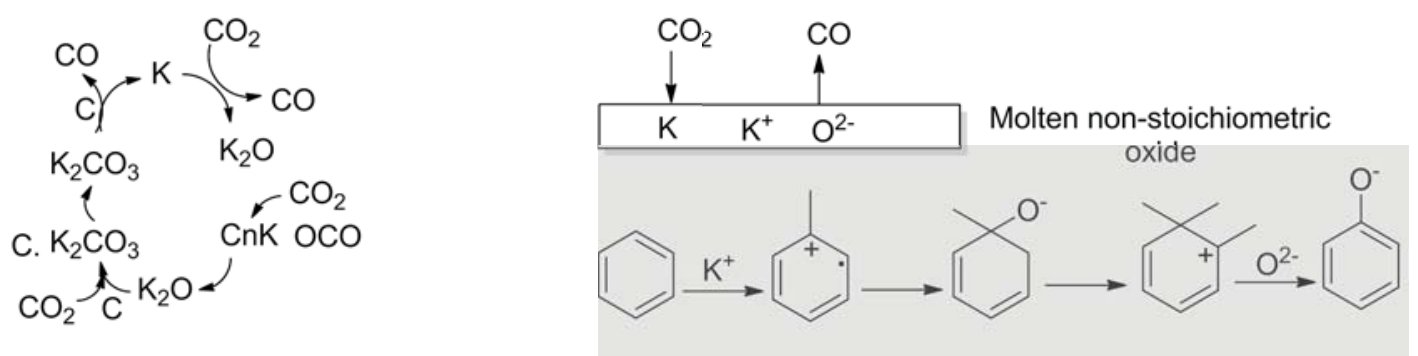

Figure 4.4. Significant mechanism for $\mathrm{K}$ catalysed $\mathrm{CO}_{2}$ gasification were critically reviewed by Moulijn et al. [5]

according to conversion levels. Furthermore, the degree of mixing of humin with $\mathrm{Na}_{2} \mathrm{CO}_{3}$ can influence the gasification rate. However, as shown in Figure 4.1-B and Figure 4.3, these were not observed. No difference in conversion rates between extended/mild mixing or conversion levels was observed. Hence, this mechanism is not likely to explain the experimental results.

For a mechanism involving oxide, the nature of active catalytic species was not clearly explained. Recently, Nagase et al.[9] suggested another pathway involving reverse Bourdard reaction in which $\mathrm{C}$ mainly reacts with $\mathrm{Na}_{2} \mathrm{O}_{2}$. The reaction pathways involved are summarised below:

$$
\begin{aligned}
& \mathrm{Na}_{2} \mathrm{CO}_{3}+\mathrm{C} \stackrel{\text { slow }}{\longrightarrow} \mathrm{Na}_{2} \mathrm{O}+2 \mathrm{CO} \\
& 2 \mathrm{Na}_{2} \mathrm{O} \stackrel{\text { rapid }}{\longrightarrow} 2 \mathrm{Na} \text { (gas) }+\mathrm{Na}_{2} \mathrm{O}_{2} \text { (liquid) }
\end{aligned}
$$




$$
\begin{aligned}
& 2 \mathrm{Na}+\mathrm{CO}_{2} \stackrel{\text { rapid }}{\longrightarrow} \mathrm{Na}_{2} \mathrm{O}+\mathrm{CO} \\
& \mathrm{Na}_{2} \mathrm{O}_{2}+\mathrm{C} \stackrel{\text { fast }}{\longrightarrow} \mathrm{Na}_{2} \mathrm{O}+\mathrm{CO} \\
& \mathrm{Na}_{2} \mathrm{O}+\mathrm{CO}_{2} \stackrel{\text { slow }}{\longrightarrow} \mathrm{Na}_{2} \mathrm{CO}_{3}
\end{aligned}
$$

According to Nagase et al. the actual catalytic cycles involve the circulation of $\mathrm{Na}_{2} \mathrm{O}-\mathrm{Na}-\mathrm{Na}_{2} \mathrm{O}_{2}$. Since reaction (7) is much faster than reaction (4), it can be considered that most of the carbon in the humin matrix is converted via reaction (7). From the stoichiometry of reactions (4), (5) and (7), it can be seen that the maximum amount of $\mathrm{Na}_{2} \mathrm{O}_{2}$ is just half of the initial amount of $\mathrm{Na}_{2} \mathrm{CO}_{3}$. In addition, the relatively low melting point of $\mathrm{Na}_{2} \mathrm{O}_{2}\left(675{ }^{\circ} \mathrm{C}\right)$, helps to create good contact between "initial" $\mathrm{Na}_{2} \mathrm{CO}_{3}$ and humin, making the reaction occur homogeneously in bulk phase of humin. This also helps to explain the constant conversion rate in the initial stages of isothermal reforming. This mechanism seems to fit the experiment data. Catalytic dry reforming of humin with labelled sodium carbonate $\left({ }^{13} \mathrm{C}\right)$ may help to verify the nature of sodium

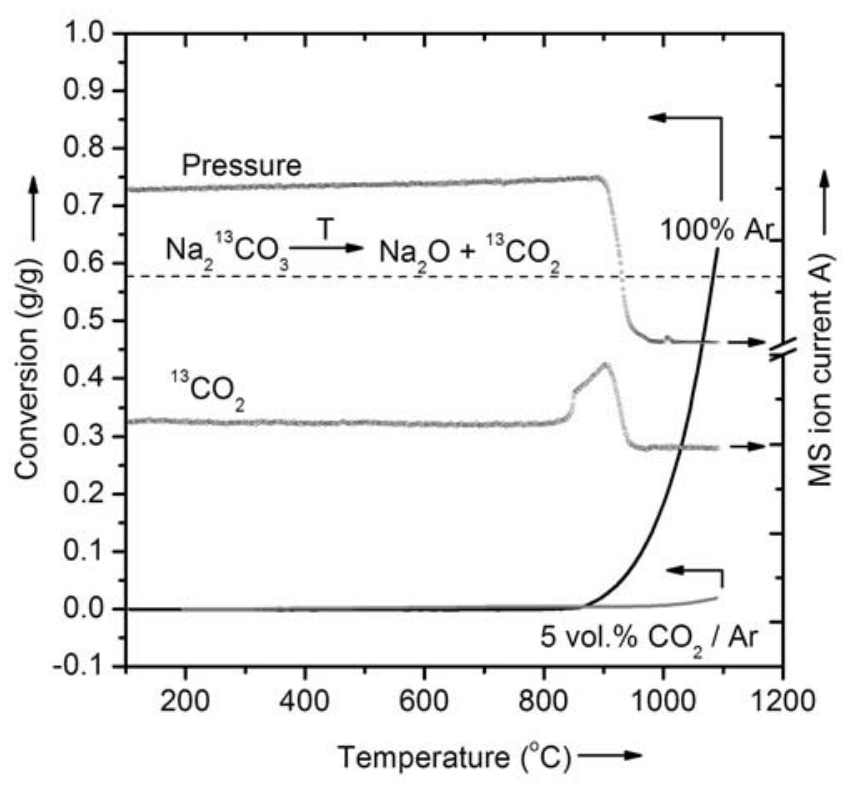

Figure 4.5. TGA profile of pure $\mathrm{Na}_{2}{ }^{13} \mathrm{CO}_{3}$ in $\mathrm{Ar}$ and $\mathrm{CO}_{2} / \mathrm{Ar}$ and gas released during thermal treatment in Ar. Dashed line indicate the conversion level of sodium carbonate is completely decomposed to $\mathrm{CO}_{2}$ and $\mathrm{Na}_{2} \mathrm{O}$. Ramp $10^{\circ} \mathrm{C} \cdot \mathrm{min}^{-1}$ carbonate.

Figure 4.5 shows the conversion of sodium carbonate in inert and $\mathrm{CO}_{2} / \mathrm{Ar}$ atmosphere and the gases released. In Ar, about 65 wt.\% of initial $\mathrm{Na}_{2}{ }^{13} \mathrm{CO}_{3}$ is converted to gas products when the oven reaches $1100^{\circ} \mathrm{C}$. This value even exceeds the maximum stoichiometry of thermal decomposition, 0.58. Thus, it implies besides the decomposition which release ${ }^{13} \mathrm{CO}_{2}$, some other species (e.g., $\mathrm{Na}, \mathrm{Na}_{2} \mathrm{O}_{2}, \mathrm{Na}_{2} \mathrm{O}$ ) escape to the gas phase. The signal for ${ }^{13} \mathrm{CO}_{2}$ starts increasing along with the onset of weight 
loss at $\sim 850{ }^{\circ} \mathrm{C}$. The volatiles would condense at the cold inlet of the MS, and we observe corresponding blockage/loss of pressure in MS (see Figure 4.5).
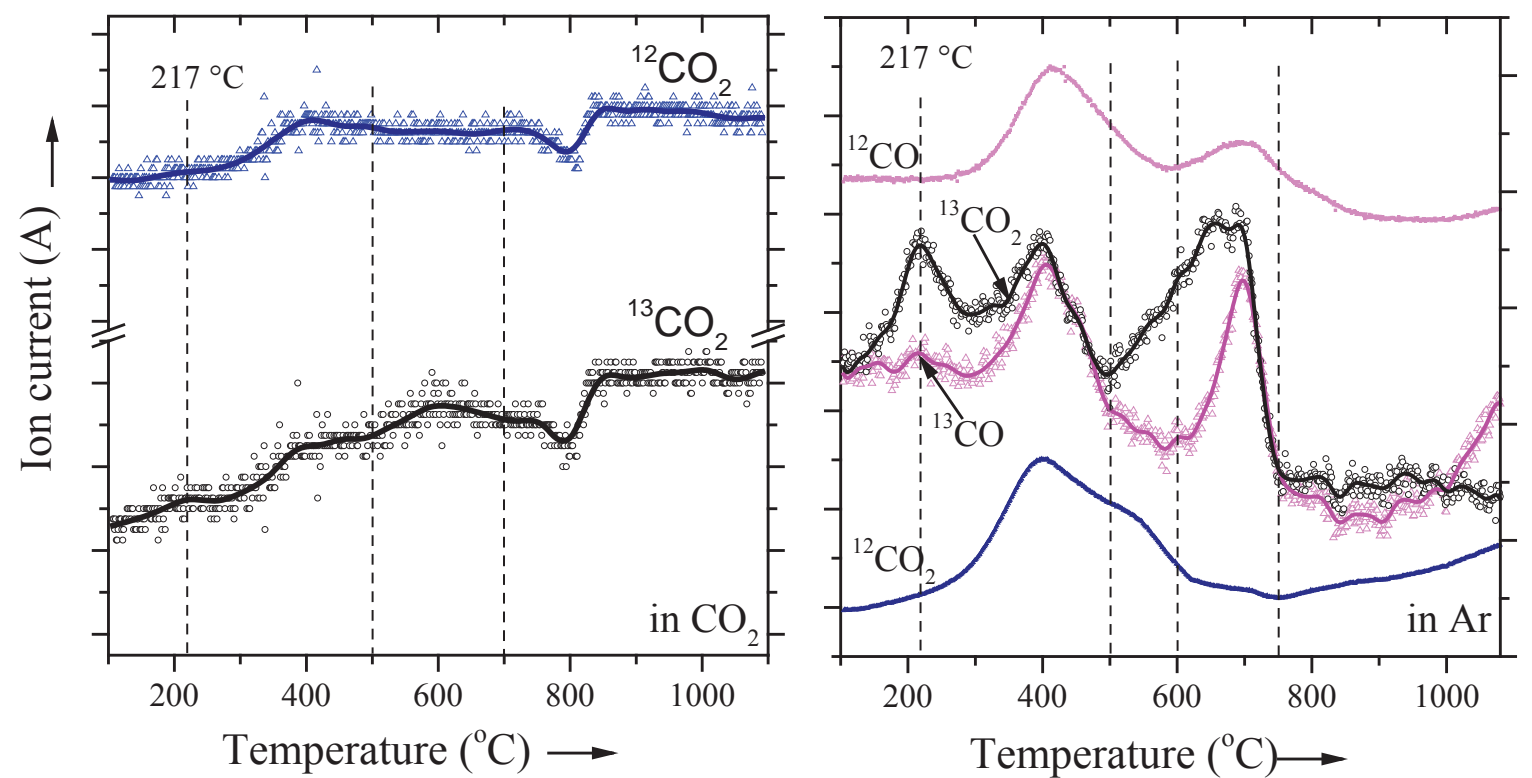

Figure 4.6. Carbon containing gas released during the heating treatment of HG1$\mathrm{Na}_{2}{ }^{13} \mathrm{CO}_{3}$ mixture in 40 vol.\% $\mathrm{CO}_{2}$ (left graph: ${ }^{12} \mathrm{CO}_{2}-\triangle,{ }^{13} \mathrm{CO}_{2}-\mathrm{O}$ ) and in $\mathrm{Ar}$ (right graph, ${ }^{13} \mathrm{CO}_{2}-\mathrm{O},{ }^{12} \mathrm{CO}-\triangle$ ). The solid lines in the left graph present the smoothing data using Fourier transformation filter with 10 points.

On the other hand, in $\mathrm{CO}_{2} / \mathrm{Ar}$, weight loss of sodium carbonate starts at $260{ }^{\circ} \mathrm{C}$ and increases with very slow rate until $700{ }^{\circ} \mathrm{C}$. The weight loss (or conversion) at this point is $0.4 \mathrm{wt} . \%$. The conversion levels off from $700{ }^{\circ} \mathrm{C}$ to $900{ }^{\circ} \mathrm{C}$ and increases again until the end of heating program, $1100{ }^{\circ} \mathrm{C}$, where $\sim 2 \mathrm{wt} \%$ loss is achieved. Since onset of the first weight loss occurs at a quite low temperature, it is not likely that this is caused by decomposition. The first weight loss is attributed to desorption of gas absorbed on sodium carbonate (e.g., $\mathrm{CO}_{2}$ ). In $\mathrm{CO}_{2}$ rich atmosphere, the decomposition reaction (reaction 9) can occur in equilibrium with the recombination reaction (reaction 10) due to the abundance of $\mathrm{CO}_{2}$ present in the gas phase. Since sodium carbonate formed in reaction (10) is 1 Dalton less than the original one, total weight loss of 0.94 wt.\% can be achieved when all the ${ }^{13} \mathrm{C}$ is replaced by ${ }^{12} \mathrm{C}$ from $\mathrm{CO}_{2}$ in gas phase. This theoretical weight loss is slightly below the final weight loss obtained at the end of the experiment. Thus, the second weight loss (onset above $900{ }^{\circ} \mathrm{C}$ ) can correspond to the exchange of the labelled $\mathrm{C}$. This result confirms the reversibility of the decomposition reaction of sodium carbonate in $\mathrm{CO}_{2}$ atmosphere. It also indicates that the 
decomposition of $\mathrm{Na}_{2} \mathrm{CO}_{3}$ occurs in $\mathrm{CO}_{2}$ at much higher temperature used for gasification $\left(900{ }^{\circ} \mathrm{C}\right.$ compared with typical $750{ }^{\circ} \mathrm{C}$ in gasification).

$$
\begin{aligned}
& \mathrm{Na}_{2}{ }^{13} \mathrm{CO}_{3} \rightarrow \mathrm{Na}_{2} \mathrm{O}+{ }^{13} \mathrm{CO}_{2} \\
& \mathrm{Na}_{2} \mathrm{O}+\mathrm{CO}_{2} \rightarrow \mathrm{Na}_{2} \mathrm{CO}_{3}
\end{aligned}
$$

Carbon containing gas released during the dry reforming reaction of humin mildly mixed with $\mathrm{Na}_{2}{ }^{13} \mathrm{CO}_{3}$ (by mortar and pestle) is displayed in Figure 4.6- left graph. Since natural abundance of ${ }^{13} \mathrm{C}$ is $1.1 \%$ the signal of ${ }^{13} \mathrm{CO}_{2}$ is the combination of ${ }^{13} \mathrm{CO}_{2}$ release from the sodium carbonate and the natural isotopic fraction of gaseous $\mathrm{CO}_{2}$ which in turn comes from two sources: (1) gas supply and (2) humin via devolatilisation. The difference in trends between $\mathrm{CO}_{2}$ and ${ }^{13} \mathrm{CO}_{2}$ signals is due to the ${ }^{13} \mathrm{CO}_{2}$ originating from sodium source which can be seen around $217{ }^{\circ} \mathrm{C}$ and in the range $500-700{ }^{\circ} \mathrm{C}$. These two ${ }^{13} \mathrm{CO}_{2}$ release stages from sodium catalyst is also seen when the humin mixture is treated in argon (Figure 4.6-right graph). In this case, the same trend can be seen more clearly since no external $\mathrm{CO}_{2}$ being present in the gas.

The release of ${ }^{13} \mathrm{CO}_{2}$ occurs at much lower temperature in comparison with that for the decomposition of pure $\mathrm{Na}_{2}{ }^{13} \mathrm{CO}_{3}$ in argon. The first peak at $217{ }^{\circ} \mathrm{C}$ can be attributed to reactions between the volatiles from humin (e.g., levulinic acid, acetic acid etc.) with some part of sodium carbonate. Such acid-base reactions can make ${ }^{13} \mathrm{CO}_{2}$ as product. During the pyrolysis stage $\left(\mathrm{RT}-600{ }^{\circ} \mathrm{C}\right)$, the carbonate salt has a high chance to interact with humin which consists of oxygen functional groups. The actual form of sodium species in this stage is unknown. They are tentatively assigned to sodium-carbonate or carboxylate complexes. The second evolution of ${ }^{13} \mathrm{CO}_{2}$ (starting at $500{ }^{\circ} \mathrm{C}$ ) may be due to the decomposition of these tentative complexes which are less stable than sodium carbonate. The forms of sodium species after $700{ }^{\circ} \mathrm{C}$ are discussed in the next section. It is tentatively attributed to carbonate or oxide type species. No further evolution of ${ }^{13} \mathrm{CO}_{2}$ is observed after $750{ }^{\circ} \mathrm{C}$ (until $1100{ }^{\circ} \mathrm{C}$ ) which implies the all the ${ }^{13} \mathrm{C}$ is consumed and released to the gas phase by $750{ }^{\circ} \mathrm{C}$. From 600 to $700{ }^{\circ} \mathrm{C}$, intensity of ${ }^{13} \mathrm{CO}_{2}$ increases to almost similar intensity of the peaks at 217 and $400{ }^{\circ} \mathrm{C}$, however, there is no corresponding increase of ${ }^{13} \mathrm{CO}$ signal. This indicates that signal of ${ }^{13} \mathrm{CO}$ caused by fragmentation of $\mathrm{Na}_{2}{ }^{13} \mathrm{CO}_{3}$ is negligible. Hence ${ }^{13} \mathrm{CO}$ signal is due to evolution of carbon monoxide either from humin or ${ }^{13} \mathrm{C}$ containing sodium complexes. The second peak of ${ }^{12} \mathrm{CO}$ centralised at $700{ }^{\circ} \mathrm{C}$ is probably the result of the reaction between humin residue and sodium complexes since it is not seen in the case of heating only humin in Ar (Figure 2.7, chapter 2). 


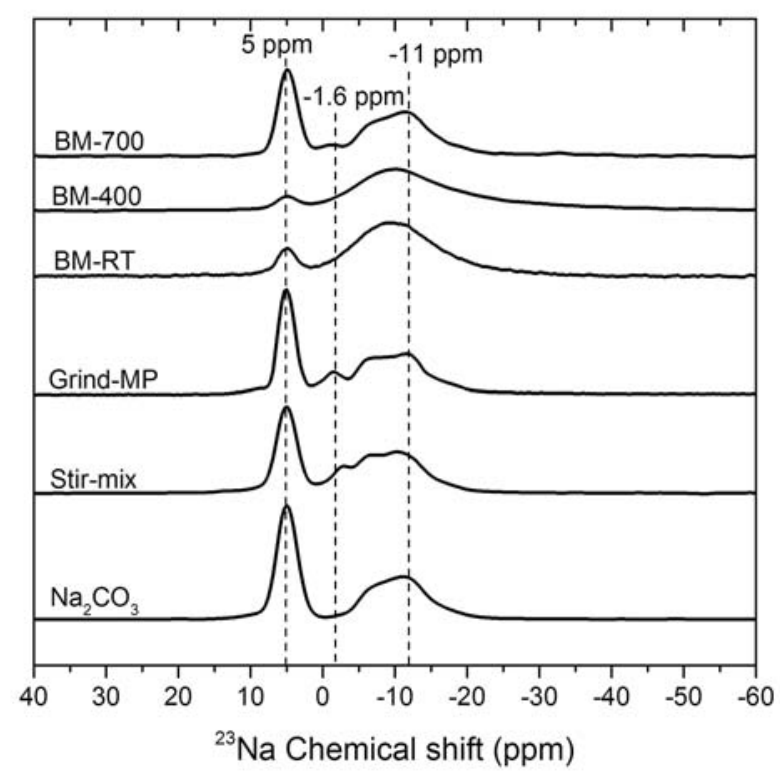

Figure 4. 7. Solid state ${ }^{23} \mathrm{Na}$ NMR of various humin- $\mathrm{Na}_{2} \mathrm{CO}_{3}$ mixture. BM-T stands for the samples was prepared by ball-milling and pre-heated in $\mathrm{CO}_{2}$ to corresponding $\mathrm{T}$ degree Celsius. Grind-MP and stir-mix is the humin mixture prepared by mixing in mortar and pestle with very low pressing force (just for stir mixing) and with pressing, respectively

Figure 4.7 shows the ${ }^{23} \mathrm{Na}$ solid state NMR spectra of humin- $\mathrm{Na}_{2} \mathrm{CO}_{3}$ mixtures with different extends of mixing and treated in $\mathrm{CO}_{2}$ atmosphere. The spectra are compared with that of pure $\mathrm{Na}_{2} \mathrm{CO}_{3}$. In general, ${ }^{23} \mathrm{Na} \mathrm{NMR}$ spectra depend on atomic environment surrounding Na nucleus [10]. The NMR spectra shown here suggest the complexity of sodium forms in these humin samples. The energy degree introduced to the mixture via the mixing activity or the thermal treatment can modify the elemental environment surrounding $\mathrm{Na}$ nucleus. Mixing humin with $\mathrm{Na}_{2} \mathrm{CO}_{3}$ in mortar and pestle can already create a small change. Ball-milling can not only improve the contact between humin and $\mathrm{Na}_{2} \mathrm{CO}_{3}$ but also generate local friction heat. The spectrum of the sample prepared by ball-milling differs from the original $\mathrm{Na}_{2} \mathrm{CO}_{3}$ in which the intensity of the main band at 5 ppm decreases and the band around -11 ppm becomes broader. The NMR patterns of the ball-milled mixture at room temperature and that pre-treated at $400{ }^{\circ} \mathrm{C}$ show a lot of similarity except that the band centralised at -11 ppm becomes even broader in the latter sample. However, for the sample pre-heated at $700{ }^{\circ} \mathrm{C}$ (all samples are cooled down to room temperature in $\mathrm{CO}_{2}$ prior to $\mathrm{NMR}$ measurement), the spectrum is almost identical to that of pure $\mathrm{Na}_{2} \mathrm{CO}_{3}$ implying that sodium remained in this sample mainly in the form of sodium carbonate. Thus, the corresponding form of sodium species at $700{ }^{\circ} \mathrm{C}$ must have the ability to convert back 
to carbonate type compounds in $\mathrm{CO}_{2}$ atmosphere when cooled down to room temperature. They tentatively correspond to either sodium carbonate or oxides. In the latter case, the reaction (4) is not required to generate sodium oxide and reaction (8) might become substantial during the cooling step. However, reaction (5), (6), (7) of the mechanism proposed by Nagase can still be applied in this case. The complete answer for the exact reaction pathways during dry reforming of humin with $\mathrm{Na}_{2} \mathrm{CO}_{3}$ indeed requires further studies.

\subsection{Conclusions}

The kinetic study on catalytic dry reforming of humin with $\mathrm{Na}_{2} \mathrm{CO}_{3}$ catalyst was investigated in this chapter. The kinetic results indicated the similar trends for different humin samples (with and without sugar residues) toward dry reforming reaction. Thus, from an application point of view, humin derived from dehydration of sugar can be used directly for gasification with minimal purification step (washing humin with water during the filtration separation is enough). The kinetic results also implied the first order dependency of gasification rate on the catalyst loading and the activation energy is in the same range for dry reforming of bio-derived char. The dry reforming with labelled sodium carbonate together with ${ }^{23} \mathrm{Na}$ NMR result tentatively revealed the form of sodium species at dry reforming condition as either carbonate or oxide forms.

\section{Bibliography}

[1] T.M.C. Hoang, L. Lefferts, K. Seshan, Valorization of humin-based byproducts from biomass processing-a route to sustainable hydrogen, ChemSusChem, 6 (2013) 1651-1658.

[2] C. Di Blasi, Combustion and gasification rates of lignocellulosic chars, Progress in Energy and Combustion Science, 35 (2009) 121-140.

[3] A. Nzihou, B. Stanmore, P. Sharrock, A review of catalysts for the gasification of biomass char, with some reference to coal, Energy, 58 (2013) 305-317.

[4] D.W. McKee, Mechanisms of the alkali metal catalysed gasification of carbon, Fuel, 62 (1983) 170-175.

[5] J.A. Moulijn, M.B. Cerfontain, F. Kapteijn, Mechanism of the potassium catalysed gasification of carbon in CO2, Fuel, 63 (1984) 1043-1047.

[6] J. Kopyscinski, M. Rahman, R. Gupta, C.A. Mims, J.M. Hill, K2CO3 catalyzed CO2 gasification of ash-free coal. Interactions of the catalyst with carbon in N2 and $\mathrm{CO} 2$ atmosphere, Fuel, 117, Part B (2014) 1181-1189. 
[7] D.W. Mckee, C.L. Spiro, P.G. Kosky, E.J. Lamby, Catalysis of Coal Char Gasification by Alkali-Metal Salts, Fuel, 62 (1983) 217-220.

[8] R.C. Brown, Q. Liu, G. Norton, Catalytic effects observed during the co-gasification of coal and switchgrass, Biomass Bioenerg, 18 (2000) 499-506.

[9] K. Nagase, T. Shimodaira, M. Itoh, Y. Zheng, Kinetics and mechanisms of the reverse Boudouard reaction over metal carbonates in connection with the reactions of solid carbon with the metal carbonates, Physical Chemistry Chemical Physics, 1 (1999) 5659-5664.

[10] J.C.C. Freitas, M.A. Schettino, A.G. Cunha, F.G. Emmerich, A.C. Bloise, E.R. de Azevedo, T.J. Bonagamba, NMR investigation on the occurrence of $\mathrm{Na}$ species in porous carbons prepared by $\mathrm{NaOH}$ activation, Carbon, 45 (2007) 1097-1104.

\section{Appendix 4}
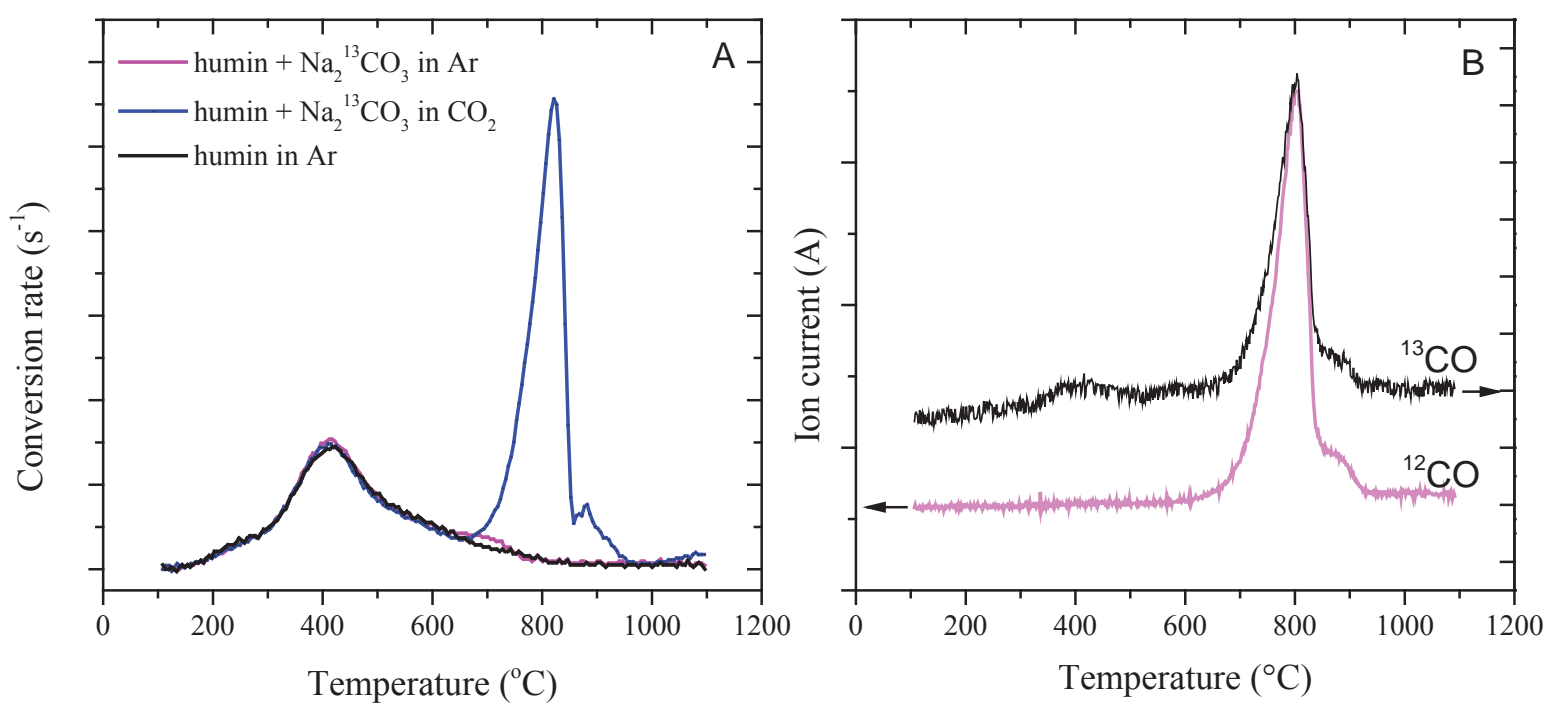

Figure A.4.1. Conversion rate of humin samples (mixed with $\mathrm{Na}_{2}{ }^{13} \mathrm{CO}_{3}$ ) in $\mathrm{CO}_{2}$ and $\mathrm{Ar}$ in comparison with that of only humin in $\operatorname{Ar}(\mathrm{A})$; Evolution of $\mathrm{CO}$ in the exhaust gas from dry reforming of humin in presence of $\mathrm{Na}_{2}{ }^{13} \mathrm{CO}_{3}(\mathrm{~B})$

Figure A 4.1-A presents the conversion rate of the gasification of humin- $\mathrm{Na}_{2}{ }^{13} \mathrm{CO}_{3}$ in $\mathrm{CO}_{2}$ and Ar. These are the experiment cases corresponding to the gas evolution shown in Figure 4.5. Figure A 4.1-B is the evolution of $\mathrm{CO}$ in the exhaust gas which corresponds to the right graph of Figure 4.5 (gasification in $\mathrm{CO}_{2}$ of humin in presence of $\mathrm{Na}_{2}{ }^{13} \mathrm{CO}_{3}$ ) 


\title{
Investigation of $\mathrm{Ce}-\mathrm{Zr}$ oxide supported $\mathrm{Ni}$ catalysts in steam reforming of meta-cresol as model component for bio-derived tar
}

\begin{abstract}
Phenols are major components in the tar vapour formed during gasification of biomass based feedstocks. The steam reforming of m-cresol was demonstrated for tar removal and $\mathrm{H}_{2}$ production in this study. Ceria-zirconia based catalysts containing Ni were developed and investigated using multiple characterisation techniques such as XRD, Raman spectroscopy, XPS, TPR/TPO etc. These catalysts show high activity and excellent stability for making hydrogen. Influence of preparation methods for support synthesis was studied. Ni on hydrothermal Ce-Zr solid solution is the most promising due to its excellent anti-coking properties which results from its high oxygen mobility. Insight into to the steam reforming reactions was investigated by in situ FT-IR spectroscopy. The IR results show that multiple sites (Ni and $\mathrm{Ce}$ ) on the catalysts are involved in the reactions.
\end{abstract}




\subsection{Introduction}

With the depletion of fossil fuels, intensified efforts in developing technology for conversion of alternative sources for energy and chemicals, especially focusing on the aspect of sustainability have been made. Biomass, tide, solar, wind are considered as sustainable resources for fuels and energy. Among them, biomass is the only renewable resource that contains carbon. Transportation fuels or fuel precursors can be produced from biomass via direct approaches (e.g., pyrolysis for bio-oil, dehydration of carbohydrates for hydroxymethyl furfural etc.) or indirectly via gasification for synthesis gas production followed by Fischer - Tropsch conversion [1]. Since bio-oil and bio-derived platform chemicals have high [O] contents [1], de-oxygenation upgrading of these components is mandatory to meet the requirement for fuels. Hydrogen is a key component for upgrading bio-oil via hydro-deoxygenation, and for hydrogenation of platform chemicals from biomass, e.g., sorbitol from cellulose. Demand for hydrogen is omnipresent in biorefinery [2]. Minimisation of the use of $\mathrm{H}_{2}$ from external sources, especially from fossil resources is obligatory for the production of bio-fuels [2]. Hydrogen can be made from biomass based feedstocks by gasification, e.g., steam reforming or partial oxidation [1,3-5]. Biomass is unstable under the elevated temperatures required for gasification, de-volatilisation and formation of tars occur $[4,6]$. Tar gasification is, thus, an important issue from the point of view of complete utilisation of the waste humin. Removal of tar is also essential for making high purity $\mathrm{H}_{2}$ for subsequent processes or its use in fuel-cells. Phenols and phenolic components such as cresols, account for the largest fraction in the composition of tars derived from bio-feedstocks $[1,7]$. In Chapter 3 on steam reforming of humin-based by-products, we addressed the issue of cresols and phenol, as the major volatile components, formed during the heating of humin to the gasification temperatures. In many studies on steam reforming of tars, model components such as phenol, benzene, toluene or acid acetic are normally chosen. The number of research studies involving steam reforming of cresols is very limited [8-11]. $m$-Cresol is a good probe molecule for study in the steam reforming of biomass due to its multiple chemical functionalities, namely aromatic ring, hydroxyl and alkyl substitutions. These chemical groups are widely present in most bio-derived tars [12]. Certainly, cresols are typical degradation components of cellulose derived humin waste. In this study, $m$-cresol is selected as a model component for the development of a catalyst for the steam reforming of volatiles formed during gasification of humin, and in general for bio-oil and tars for making hydrogen.

Commercial steam reforming nickel (Ni) catalysts have been widely used for tars gasification [6, 12]. Ni catalysts show high, demonstrated activity [6]. However, the disadvantage of Ni catalyst in reforming of tars is the rapid deactivation, mainly due to coke 
formation. For example, coke deposition rate in steam reforming of $m$-cresol can be as high as 20 - $140 \mathrm{mg}$ coke/g $\mathrm{g}_{\text {catalyst }} \mathrm{h}$ when a $\mathrm{Ni} / \mathrm{MgO}$ commercial catalyst (WC series - supplied by Wuxi Qiangya Co. Ltd) was used [8]. Ishihara et al.[10] reported that both conversion of $m$ cresol and hydrogen yield dropped from 100 to $~ 80 \%$ within 4 hours when 15 wt.\% Ni - 2 wt. $\% \mathrm{Ru} / \mathrm{MgO}-\mathrm{La}_{2} \mathrm{O}_{3}-\mathrm{Al}_{2} \mathrm{O}_{3}$ catalyst was used. Tomisghe's group designed an effective catalyst - $\mathrm{Ni} / \mathrm{CeO}_{2}-\mathrm{Al}_{2} \mathrm{O}_{3}$ for removal of tars from biomass via auto-thermal reforming, i.e, in the presence of oxygen [13]. They claimed that the "excellent performance" [13] of the catalyst was due to the strong interaction of $\mathrm{Ni}$ with $\mathrm{CeO}_{2}$, and explained this as due to oxygen mobility between $\mathrm{Ni}$ and $\mathrm{CeO}_{2}$. In general, $\mathrm{CeO}_{2}$ is a key component of commercial catalysts when oxidation is required such as in three-way automotive exhaust gas clean up systems [14]. It has facile redox properties and oxygen storage capacity which facilitate oxidation reactions. Since gasification is essentially an oxidation reaction with $\mathrm{H}_{2} \mathrm{O}$, or $\mathrm{CO}_{2}$, using $\mathrm{CeO}_{2}$ as support or a promoter for steam reforming catalysts may also help improve the oxidation of coke. Oxygen mobility of $\mathrm{CeO}_{2}$ is much enhanced by introducing foreign ions such as $\mathrm{Zr}^{4+}, \mathrm{Gd}^{3+}$ or $\mathrm{Tb}^{4+}$ into the $\mathrm{CeO}_{2}$ lattice $[15,16]$. According to Di Monte et al., $[15,17]$ the oxygen ion mobility within the crystal lattice originates from the formation of a defective solid solution in which, for example $\mathrm{Zr}^{4+}$ (ionic radius 0.84 ) replaces some $\mathrm{Ce}^{4+}$ cations (ionic radius 0.96). Matas Güell et al. showed that $\mathrm{Ni} / \mathrm{CeO}_{2}-\mathrm{ZrO}_{2}$ in which $\mathrm{CeO}_{2}$ was impregnated on $\mathrm{ZrO}_{2}$ oxide prior the deposition of $\mathrm{Ni}$, is active and more stable under the steam reforming of phenol [18]. In this study, the influence of ceria-zirconia mixed oxide supports on Ni based catalysts for the steam reforming for the $m$-cresol is investigated.

\subsection{Experiment}

\subsubsection{Catalyst preparation}

\section{Syntheses of Ce-Zr mixture:}

Stoichiometric amounts of $\mathrm{Ce}\left(\mathrm{NO}_{3}\right)_{3} \cdot 6 \mathrm{H}_{2} \mathrm{O}$ and $\mathrm{ZrO}\left(\mathrm{NO}_{3}\right)_{2} \cdot 6 \mathrm{H}_{2} \mathrm{O}(\mathrm{Ce} / \mathrm{Zr} 0.25)$ were dissolved in de-mineralised water. The initial $\mathrm{pH}$ of this solution was about 0.5 . The solution was heated to $\sim 80{ }^{\circ} \mathrm{C}$ under vigorous magnetic agitation. $\mathrm{NH}_{3} 10 \%$ was slowly added dropwise into the precursor solution until $\mathrm{pH}$ reached 8.5 in order to precipitate most of the precursor species (the gel of cerium-zirconium hydroxide complex started forming at $\mathrm{pH} \sim$ 3.5). Cerium-zirconium gel was then filtered with a Büchner funnel and washed with demiwater until the effluent reached to neutral $\mathrm{pH}$. A part of the gel was then dried at $80{ }^{\circ} \mathrm{C}$ in a vacuum dryer overnight prior to calcination in air. The calcination procedure is described later. This solid powder after calcination is denoted as CP as it was made via co-precipitation method. Other part of the gel after the co-precipitation step was transferred to a $100 \mathrm{ml}$ non- 
stirred autoclave with Teflon liner. $40 \mathrm{ml} \mathrm{KOH} 40$ wt.\% was added to the gel. The sealed autoclave was then heated to $180{ }^{\circ} \mathrm{C}$ and maintained at this temperature for 24 hours in a static oven. Afterward, the autoclave was slowly cooled down to room temperature. The product was then filtered and washed with large amount of demineralised water until the $\mathrm{pH}$ of the effluent became neutral ( $\mathrm{pH} \sim 8$ ). The sample was subsequently dried in a vacuum oven overnight followed by calcination in air. The final product obtained after calcination step is denoted as HT (hydrothermal treatment).

Commercial monoclinic $\mathrm{ZrO}_{2}$ oxide (RC-100, Gimex Technisch Keramik B.V.) was first calcined in air at $800{ }^{\circ} \mathrm{C}$ with flow rate $50 \mathrm{ml} \cdot \mathrm{min}^{-1}$ for $6 \mathrm{~h}$ (heating or cooling rate 5 $\left.{ }^{\circ} \mathrm{C} . \mathrm{min}^{-1}\right)$. Ceria was deposited on $m-\mathrm{ZrO}_{2}$ via wet impregnation method. $\mathrm{Ce}\left(\mathrm{NO}_{3}\right)_{3} \cdot 6 \mathrm{H}_{2} \mathrm{O}$ was dissolved in $50 \mathrm{ml}$ demi-water. $m-\mathrm{ZrO}_{2}$ was then dispersed in the $\mathrm{Ce}\left(\mathrm{NO}_{3}\right)_{3}$ solution. The solvent was then removed using a rotary evaporator under vacuum. Subsequently, the sample was dried further in vacuum oven at $80{ }^{\circ} \mathrm{C}$ overnight. After subjecting to calcination treatment, the support prepared via impregnation route is denoted as IM (impregnation).

\section{Calcination treatment of Ce-Zr support:}

Solid samples obtained after drying in vacuum oven, were then heated in air with a flow rate of $50 \mathrm{ml} \cdot \mathrm{min}^{-1}$. The furnace was first heated to $150{ }^{\circ} \mathrm{C}$ with temperature ramp $5{ }^{\circ} \mathrm{C} \cdot \mathrm{min}^{-1}$ and kept at $150{ }^{\circ} \mathrm{C}$ for 1 hour. Then, the furnace temperature was increased to $725{ }^{\circ} \mathrm{C}$ with heating rate $5{ }^{\circ} \mathrm{C} \cdot \mathrm{min}^{-1}$, kept at that temperature for 6 hours prior to cooling down at the rate 5 ${ }^{\circ} \mathrm{C} . \mathrm{min}^{-1}$ to room temperature.

\section{Deposition of Nickel:}

Nickel (Ni) was deposited on these supports via homogeneous deposition precipitation technique. Typically, $0.1734 \mathrm{~g} \mathrm{Ni}\left(\mathrm{NO}_{3}\right)_{3} \cdot 6 \mathrm{H}_{2} \mathrm{O} 99 \%$ was dissolved in demi-water in a round flask with vigorous agitation. Then $c a .1 \mathrm{~g}$ support was dispersed in the solution. The mixture temperature was preheated to $75^{\circ} \mathrm{C}$. A solution containing $\sim 4.5 \mathrm{~g}$ urea was poured into the mixture at this point. The total volume of liquid was $250 \mathrm{ml}$. Subsequently, the mixture temperature was increased to $90{ }^{\circ} \mathrm{C}$ and kept at this temperature until the deposition completed ( $4-5 \mathrm{~h}$, final $\mathrm{pH}$ of 7.5). Samples were then filtered and washed with demi-water prior to drying in the vacuum oven $\left(80^{\circ} \mathrm{C}\right)$ for 3 hour. After that, the solid samples were calcined (air flow rate $50 \mathrm{ml} \cdot \mathrm{min}^{-1}$ ) at $500{ }^{\circ} \mathrm{C}$ for $3 \mathrm{~h}$ with heating rate $5{ }^{\circ} \mathrm{C} \cdot \mathrm{min}^{-1}$. All catalysts were reduced in 10 vol.\% $\mathrm{H}_{2} / \mathrm{N}_{2}$ at $650{ }^{\circ} \mathrm{C}$ (ramping temperature $10{ }^{\circ} \mathrm{C} \cdot \mathrm{min}^{-1}$ ) for 3 hours. After the reduction step, catalysts were denoted as $\mathrm{Ni} / \mathrm{CP}, \mathrm{Ni} / \mathrm{HT}, \mathrm{Ni} / \mathrm{IM}$, respectively.

\subsubsection{Catalyst characterisation}


The texture of these catalysts (specific area, pore size distribution) was determined from liquid nitrogen adsorption/desorption isothermal curves acquired with a Micromeritics TriStar instrument. Samples were degassed at $300{ }^{\circ} \mathrm{C}$ prior to the analysis. X-Ray diffraction data were recorded with a Bruker D2 Phaser diffractometer using $\mathrm{Cu} K \alpha$ radiation $(\lambda=0.1544 \mathrm{~nm})$. The elemental composition of the catalysts was analysed by a X-ray fluorescence (XRF) spectrometer (Philips PW 1480). X-ray photoelectron (XPS) analysis was measured with a Quantera SXM (scanning XPS microprobe) spectrometer from Physical Electronics. X-ray $\left(\mathrm{Al} \mathrm{K} \mathrm{K}_{\alpha}\right)$ power of $50 \mathrm{~W}, 20 \mathrm{~mA}$ and beam size $200 \mu \mathrm{m}$ was used.

Temperature programmed reduction (TPR) or oxidation (TPO) was performed in a homebuilt set-up. For TPO and TPR measurement, $10-50 \mathrm{mg}$ catalyst or supports with grain size $0.3-0.6 \mathrm{~mm}$ were packed between two quartz plugs in a $4 \mathrm{~mm}$ i.d. $\alpha$-alumina tube. Before TPR or TPO analysis, samples were pre-treated in inert gas at $150{ }^{\circ} \mathrm{C}$ for 30 minutes. Then the oven was cooled to room temperature. For TPR analysis, 5 vol. $\% \mathrm{H}_{2} / \mathrm{Ar}$ with flow rate $25 \mathrm{ml} \cdot \mathrm{min}^{-1}$ was used. The $\mathrm{H}_{2}$ consumption was monitored with a standard thermal conductivity detector calibrated by $\mathrm{H}_{2}$ reduction of $\mathrm{NiO}$ (purity 99.999\%). For TPO analysis, 1 vol. $\% \mathrm{O}_{2} / \mathrm{He}$ with flow rate $75 \mathrm{ml} \mathrm{min}^{-1}$ was sent through the reactor. The gas outlet containing $\mathrm{CO}$ or $\mathrm{CO}_{2}$ was sent (split ratio 6\%) to an online methanizer (Model 110 Chassis, SRI Instruments Europe $\mathrm{GmbH}$ ) equipped with a FID detector. $\mathrm{CO}_{\mathrm{x}}$ produced was calibrated using $\mathrm{Al}_{2}\left(\mathrm{CO}_{3}\right)_{3}$ as carbon source standard (the $\mathrm{C}$ content of $\mathrm{Al}_{2}\left(\mathrm{CO}_{3}\right)_{3}$ was determined with CHNS elemental analyser, mentioned in chapter 2). In a typical TPR or TPO measurement, the furnace was heated to $700{ }^{\circ} \mathrm{C}$ with heating ramp $5{ }^{\circ} \mathrm{C} \cdot \mathrm{min}^{-1}$ then kept at that end temperature for 30 minutes before cooling down to room temperature $\left(10^{\circ} \mathrm{C} \cdot \mathrm{min}^{-1}\right)$.

Raman spectroscopy data were obtained with a Bruker Senterra Raman spectrometer (laser wavenumber $532 \mathrm{~cm}^{-1}$ ) at ambient conditions. The spectra were recorded with laser power of $5 \mathrm{~mW}$, exposed time of $1-2 \mathrm{~s}$. The spectra represent 50-100 scans with spectral resolution $3-5 \mathrm{~cm}^{-1}$.

\subsubsection{Catalytic testing}

$15 \mathrm{mg}$ of catalysts (or supports) with grain size of $0.3-0.6 \mathrm{~mm}$ were packed in an $\alpha$ alumina fixed bed reactor (i.d. $4 \mathrm{~mm}$ ) and held in place between two quartz wool plugs. The catalyst/support was first reduced in situ in $10 \% \mathrm{H}_{2} / \mathrm{Ar}$ (flow rate $50 \mathrm{ml} . \mathrm{min}^{-1}$, temperature ramp $\left.10{ }^{\circ} \mathrm{C} \mathrm{min}^{-1}\right)$ at $650{ }^{\circ} \mathrm{C}$ for $1 \mathrm{~h}$. The reactor was then purged with Ar for about 30 minutes before furnace temperature was raised to $700{ }^{\circ} \mathrm{C}$. An aqueous solution of $m$-cresol ( $20 \mathrm{gL}^{-1}$ ) was sent to an evaporator using a syringe pump (ISCO Model $500 \mathrm{D}$ ). The solution was vapourised at $140{ }^{\circ} \mathrm{C}$. The $m$-cresol/steam mixture was carried to the reactor by Ar flow 
(flow rate $25 \mathrm{ml} \cdot \mathrm{min}^{-1}$ ). Ar was also used as internal standard gas for the outlet gas mixture. With such flow-rates, the weight hourly space velocity of $m$-cresol (WHSV) is equal to 7.89 $\mathrm{h}^{-1}$. The outlet gas stream passed through a flash separator where the condensed liquid was sampled every hour and the gas was sent directly to an online Varian gas chromatograph (GC, CP-3800) with three parallel separation channels using multiple GC columns (channel 1: Hayesep Q, Hayesep T, Molsieve 13X; channel 2: Hayesep Q, Molsieve 5A; channel 3: CP Wax 52CB). The GC was equipped with TCD detectors for quantification of permanent gases $\left(\mathrm{CO}, \mathrm{CO}_{2}, \mathrm{H}_{2}, \mathrm{Ar}\right)$ and a FID detector for quantification of hydrocarbons.

The condensed liquid from the flash separator was analysed offline with a Shimadzu reverse phased High Performance Liquid Chromatograph Prominence system equipped with a Hypesil $^{\mathrm{TM}}$ Gold column and an UV detector ( $\lambda 254 \mathrm{~nm}$ ). A mobile phase containing water/methanol 40/60 (v/v) with flowrate of $0.5 \mathrm{ml} . \mathrm{min}^{-1}$ was used for analysis. The column oven was kept at $40{ }^{\circ} \mathrm{C}$. Typically, it took 15 minutes for an analysis.

$m$-Cresol conversion was calculated as the mole of $m$-cresol reacted divided by the moles of $m$-cresol in the feed (see Appendix 5). Hydrogen yield was defined as the mole of hydrogen produced divided by the maximum amount of $\mathrm{H}_{2}$ that can be produced based on the following reaction:

$$
\mathrm{C}_{7} \mathrm{H}_{8} \mathrm{O}+13 \mathrm{H}_{2} \mathrm{O} \rightarrow 7 \mathrm{CO}_{2}+17 \mathrm{H}_{2}
$$

Therefore yields and selectivity to $\mathrm{H}_{2}, \mathrm{CO}_{\mathrm{x}}$, and phenol were calculated as following:

$$
\begin{aligned}
& \text { Yield of } \mathrm{H}_{2}(\%)=100 \% \times \frac{\text { mole of hydrogen produced }}{17 \times \text { mole of } m \text {-cresol feed }} \\
& \text { Yield of phenol }(\%)=100 \% \times \frac{6 \times \text { mole of phenol }}{7 \times \text { mole of } m \text {-cresol feed }} \\
& \text { Yield of } \mathrm{CO}_{\mathrm{x}}(\%)=100 \% \times \frac{\text { mole of } \mathrm{CO}_{\mathrm{x}}}{7 \times \text { mole of } m \text {-cresol feed }} \\
& \text { Selectivity of phenol }(\%)=100 \% \times \frac{6 \times \text { mole of phenol }}{7 \times \text { mole of } m \text {-cresol reacted }} \\
& \text { Selectivity of } \mathrm{CO}_{\mathrm{x}}(\%)=100 \% \times \frac{\text { mole of } \mathrm{CO}_{\mathrm{x}}}{7 \times \text { mole of m-cresol reacted }}
\end{aligned}
$$

\subsubsection{In situ FT-IR study on reforming of $m$-cresol}

Transmission FTIR (Fourier Transmission Infra-red) spectra were recorded using a Bruker Vector 22 equipped with a MCT detector with time interval of $120 \mathrm{~s}$. Each spectrum is 
the average of 128 scans with spectral resolution of $4 \mathrm{~cm}^{-1}$. Typically, a self-supporting disc ( $\sim 10 \mathrm{mg}$ of sample) was placed into a purpose built stainless steel cell. FTIR spectra of the empty cell with helium flow $\left(20 \mathrm{ml} \cdot \mathrm{min}^{-1}\right)$ at $21{ }^{\circ} \mathrm{C}$ were recorded an used as background. $\mathrm{m}$ Cresol reforming reactions were performed on titration basis. Samples were pre-treated in $10 \% \mathrm{H}_{2} / \mathrm{He}$ (flowrate $20 \mathrm{ml} \cdot \mathrm{min}^{-1}$, temperature ramp $10{ }^{\circ} \mathrm{C} \cdot \mathrm{min}^{-1}$ ) at $450{ }^{\circ} \mathrm{C}$ for an hour. The IR cell containing samples was then outgassed with helium for 30 minutes prior to adsorption of $m$-cresol and then steam. Each adsorption step was performed for an hour and followed by flushing the cell with $\mathrm{He}$ for 30 minutes. For the $m$-cresol adsorption or steam adsorption, $\mathrm{He}$ was flown through a saturator at $21{ }^{\circ} \mathrm{C}$ filled with $m$-cresol (Sigma Aldrich $>98 \%$ purity) or filled with demineralised water, respectively, resulting $m$-cresol partial pressure of $13 \mathrm{~Pa}$ (estimated from Antoine equation formula proposed by Biddiscombe and Martin [19]) or $\mathrm{H}_{2} \mathrm{O}$ partial pressure of $\sim 2500 \mathrm{~Pa}$, respectively. The tubing from saturators to the cell was heated at $150{ }^{\circ} \mathrm{C}$ in order to prevent condensation.

\subsection{Results and discussion}

\subsubsection{Catalyst characterisation}

\section{Structure and texture characterisation}
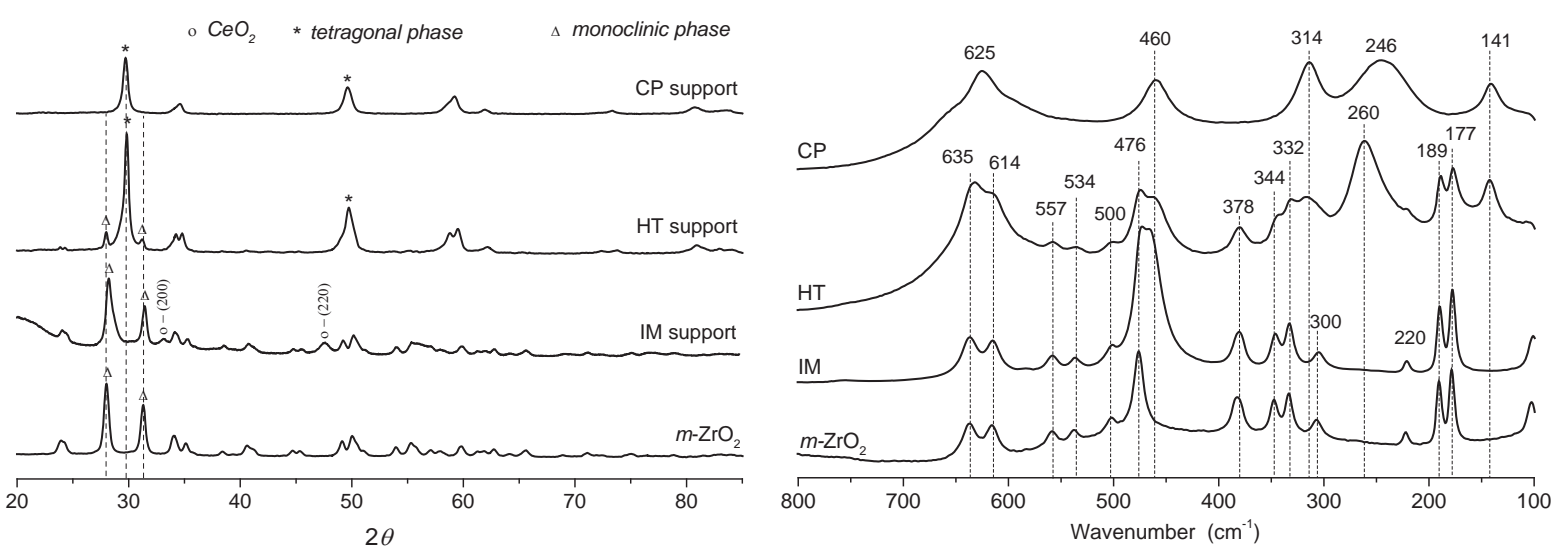

Figure 5.1. XRD of catalyst supports

Figure 5.2. Raman spectra of catalyst supports

Figure 5.1 shows the XRD spectra of the supports prepared. The XRD pattern of the IM support inherits all the major structural features of its initial support-precursor i.e., $m$ $\mathrm{ZrO}_{2}$. However, the main peak at $\sim 28^{\circ}$ shifts to $28.2^{\circ}$ with an asymmetric shape. This shift might be due to the overlapped peak of cubic $\mathrm{CeO}_{2}$ (111) which appears at $28.55^{\circ}$. In addition, two distinct peaks of $\mathrm{CeO}_{2}$ are found at $33.1^{\circ}$ and $47.4^{\circ}$ which correspond to $\mathrm{CeO}_{2}$ (200) and $\mathrm{CeO}_{2}$ (220), respectively. Thus, the impregnation support is regarded as a mixture of $\mathrm{CeO}_{2}$ and $\mathrm{ZrO}_{2}$ oxides. In contrast, the $\mathrm{CP}$ support contains only one single tetragonal 
phase of $\mathrm{ZrO}_{2}$, which indicates that $\mathrm{CeO}_{2}$ distributed homogenously in the $\mathrm{ZrO}_{2}$ lattice to form a solid solution. The XRD spectrum of HT support indicates the presence of both tetragonal and monoclinic phases without any segregation of $\mathrm{CeO}_{2}$. The transition of tetragonal to monoclinic had been claimed to be caused by the influence of the strong alkaline medium (viz. KOH 40 wt.\%) used in the hydrothermal step [20].

Table 5.1. Frequencies of Raman modes observed in the case of $\mathrm{ZrO}_{2} / \mathrm{CeO}_{2}$ materials and associated symmetries

\begin{tabular}{|c|c|c|c|c|c|c|c|c|c|}
\hline \multicolumn{3}{|c|}{$m-\mathrm{ZrO}_{2}$} & \multicolumn{2}{|c|}{ IM } & \multicolumn{2}{|c|}{ HT } & \multicolumn{3}{|c|}{$\mathrm{CP}$} \\
\hline Vibration & Mode & $v^{[\mathrm{a}]}$ & Mode & $v^{[\mathrm{a}]}$ & Mode & $v^{[\mathrm{a}]}$ & Vibration & Mode & $v^{[a]}$ \\
\hline$(\mathrm{O}-\mathrm{O})$ & $A_{g}$ & 101 & $A_{g}$ & 101 & $\mathrm{~B}_{1 \mathrm{~g}}$ & 141 & & $\mathrm{~B}_{1 \mathrm{~g}}$ & 141 \\
\hline$(\mathrm{Zr}-\mathrm{Zr})$ & $\mathrm{A}_{\mathrm{g}}$ & 177 & $\mathrm{~A}_{\mathrm{g}}$ & 177 & $\mathrm{~A}_{\mathrm{g}}$ & 177 & & & \\
\hline$(\mathrm{Zr}-\mathrm{Zr})$ & $A_{g}$ & 189 & $A_{g}$ & 190 & $\mathrm{~A}_{\mathrm{g}}$ & 189 & \multirow{2}{*}{$\begin{array}{c}\mathrm{Zr}-\mathrm{O} \\
\text { stretching }\end{array}$} & \multirow{2}{*}{$\mathrm{E}_{\mathrm{g}}$} & \multirow{2}{*}{246} \\
\hline$(\mathrm{Zr}-\mathrm{Zr})$ & $\mathrm{B}_{\mathrm{g}}$ & 220 & $\mathrm{~B}_{\mathrm{g}}$ & 221 & $\mathrm{~B}_{\mathrm{g}}$ & 220 & & & \\
\hline$(\mathrm{Zr}-\mathrm{O})$ & $\mathrm{A}_{\mathrm{g}}$ & 305 & $\mathrm{~A}_{\mathrm{g}}$ & 305 & $E_{g}$ & 260 & & $\mathrm{~B}_{1 \mathrm{~g}}$ & 314 \\
\hline$(\mathrm{Zr}-\mathrm{Zr})$ & $\mathrm{B}_{\mathrm{g}}$ & 332 & $A_{g}$ & 333 & $\mathrm{~B}_{1 \mathrm{~g}}$ & 314 & & & \\
\hline$(\mathrm{Zr}-\mathrm{O})$ & $\mathrm{A}_{\mathrm{g}}$ & 344 & $\mathrm{~A}_{\mathrm{g}}$ & 346 & $\mathrm{~A}_{\mathrm{g}}$ & 332 & \multirow{2}{*}{$\begin{array}{c}\text { asymmetric } \\
\text { M-O-M }\end{array}$} & \multirow{2}{*}{$E_{g}$} & \multirow{2}{*}{460} \\
\hline$(\mathrm{Zr}-\mathrm{O})$ & $\mathrm{B}_{\mathrm{g}}$ & 378 & $\mathrm{~B}_{\mathrm{g}}$ & 381 & $\mathrm{~A}_{\mathrm{g}}$ & 344 & & & \\
\hline$(\mathrm{O}-\mathrm{O})$ & $\mathrm{A}_{\mathrm{g}}$ & 476 & $\mathrm{~F}_{2 \mathrm{~g}}$ & 465 & $\mathrm{~B}_{\mathrm{g}}$ & 378 & & $\mathrm{~A}_{1 \mathrm{~g}}$ & 625 \\
\hline$(\mathrm{O}-\mathrm{O})$ & $\mathrm{B}_{\mathrm{g}}$ & 500 & $\mathrm{~A}_{\mathrm{g}}$ & 476 & $E_{g}$ & 460 & & & \\
\hline$(\mathrm{O}-\mathrm{O})$ & $\mathrm{B}_{\mathrm{g}}$ & 534 & $\mathrm{~B}_{\mathrm{g}}$ & 500 & $A_{g}$ & 474 & & & \\
\hline$(\mathrm{O}-\mathrm{O})$ & $\mathrm{A}_{\mathrm{g}}$ & 557 & $\mathrm{~B}_{\mathrm{g}}$ & 534 & $\mathrm{~B}_{\mathrm{g}}$ & 500 & & & \\
\hline$(\mathrm{O}-\mathrm{O})$ & $\mathrm{B}_{\mathrm{g}}$ & 614 & $\mathrm{~A}_{\mathrm{g}}$ & 558 & $\mathrm{~B}_{\mathrm{g}}$ & 534 & & & \\
\hline \multirow[t]{3}{*}{$(\mathrm{O}-\mathrm{O})$} & $\mathrm{A}_{\mathrm{g}}$ & 635 & $\mathrm{~A}_{\mathrm{g}}$ & 615 & $\mathrm{~A}_{\mathrm{g}}$ & 557 & & & \\
\hline & & & $A_{g}$ & 637 & $\mathrm{~A}_{\mathrm{g}}$ & 614 & & & \\
\hline & & & & & $A_{g}$ & 635 & & & \\
\hline
\end{tabular}

The Raman spectra of Ce- $\mathrm{ZrO}_{2}$ supports are illustrated in Figure 5.2. The assignment of vibration frequencies is based on the work by B. K. Kim et al. [21], Anastassakis et al. [22], Hirata et al [23, 24], D. J. Kim et al. [25] and summarized in Table 5.1. For the reference $m$ $\mathrm{ZrO}_{2}$ (calcined at $800^{\circ} \mathrm{C}, 6$ hours) 14 (of the 18) Raman active modes of monoclinic structure were observed, as also reported by others. The IM support also shows all these frequencies, besides a broader peak in the region $\sim 470 \mathrm{~cm}^{-1}$. This broad band is due to the overlap of the peak at $\sim 476 \mathrm{~cm}^{-1}\left(\mathrm{~A}_{\mathrm{g}}\right.$ mode of $\left.\mathrm{ZrO}_{2}\right)$ and the peak $\sim 465 \mathrm{~cm}^{-1}\left(\mathrm{~F}_{2 \mathrm{~g}}\right.$ of $\left.\mathrm{CeO}_{2}\right)$. 
On the other hand, for CP support, six frequencies $\left(1 \mathrm{~A}_{1 \mathrm{~g}}+3 \mathrm{E}_{\mathrm{g}}+2 \mathrm{~B}_{1 \mathrm{~g}}\right)$ are typical for tetragonal structure. Raman spectrum of HT support is a combination of both features indicating the presence of both monoclinic and tetragonal phases. Raman spectral results are thus in excellent agreement with XRD results. The shift to higher value of $E_{g}$ mode at $246 \mathrm{~cm}^{-}$ ${ }^{1}$ in the case of HT support is due to the decrease in the lattice parameter as result of solid solution formation, resulting in lower metal-oxygen bond length [17].

Table 5.2. Physical and chemical properties of catalysts

\begin{tabular}{|c|c|c|c|c|c|c|c|c|}
\hline \multirow{2}{*}{$\begin{array}{l}\text { Sample } \\
\text { ID }\end{array}$} & \multirow{2}{*}{$\begin{array}{c}\text { BET } \\
\text { specific } \\
\text { area } \\
\left(\mathrm{m}^{2} / \mathrm{g}\right)\end{array}$} & \multirow{2}{*}{$\begin{array}{c}\mathrm{V}_{\text {pore }} \\
\left(\mathrm{cm}^{3} / \mathrm{g}\right)\end{array}$} & \multicolumn{3}{|c|}{$\begin{array}{l}\text { Bulk Elemental composition } \\
\text { (based on XRF) }\end{array}$} & \multicolumn{3}{|c|}{$\begin{array}{l}\text { Surface elemental composition } \\
\text { (based on XPS) }\end{array}$} \\
\hline & & & $\begin{array}{c}\mathrm{Ni} / \mathrm{Zr} / \mathrm{Ce} \\
\text { (atomic ratio) }\end{array}$ & $\mathrm{Ce} / \mathrm{Zr}$ & $\begin{array}{c}\mathrm{Ni} \\
(\mathrm{wt} . \%)\end{array}$ & $\begin{array}{c}\mathrm{Ni} / \mathrm{Zr} / \mathrm{Ce} \\
\text { (atomic ratio) }\end{array}$ & $\mathrm{Ce} / \mathrm{Zr}$ & $\begin{array}{c}\mathrm{Ni} \\
\text { (count) }\end{array}$ \\
\hline $\mathrm{CP}$ & 10 & 0.11 & - & - & & - & - & \\
\hline HT & 53.7 & 0.30 & - & - & & - & - & \\
\hline $\mathrm{Ni} / \mathrm{CP}^{*}, \dagger$ & 2.7 & 0.01 & $3 / 85.2 / 10.8$ & 0.12 & 1.7 & $8.3 / 79.7 / 12$ & 0.15 & 44952 \\
\hline $\mathrm{Ni} / \mathrm{HT}^{\#, \uparrow}$ & 42.2 & 0.29 & $7.1 / 76.8 / 15.3$ & 0.2 & 3.2 & $14.7 / 69.2 / 16.1$ & 0.23 & 48515 \\
\hline Ni-IM & 35.4 & 0.47 & $6 / 78 / 16$ & 0.2 & 2.9 & $18.7 / 53.9 / 27.4$ & 0.51 & 55645 \\
\hline $\begin{array}{l}\text { *: Ni/CP } \\
\text { \#: Ni/HT } \\
\text { †: These } \\
\text { came frot }\end{array}$ & catalyst ce & ontains & $\begin{array}{l}.5 \% \mathrm{HfO}_{2} \text { (base } \\
\mathrm{HfO}_{2} \text { (based } \mathrm{O}\end{array}$ & $\begin{array}{l}\text { d on } X R \\
\text { (XRF) }\end{array}$ & F) & J & $w h$ & $\begin{array}{l}\text { obably } \\
\text { XPS }\end{array}$ \\
\hline
\end{tabular}

The physicochemical characteristics of the catalysts are summarised in Table 5.2. Catalysts made with the IM and HT supports have higher surface areas and pore volumes even after the thermal treatments $\left(725^{\circ} \mathrm{C}\right.$ calcination, and $650{ }^{\circ} \mathrm{C}$ reduction). In comparison, $\mathrm{CP}$ based catalysts have low surface areas. In general, the texture of the $\mathrm{Ce}-\mathrm{Zr}$ solid solution strongly depends upon synthesis parameters such as type of precursors, precipitation agent $\left(\mathrm{OH}^{-}\right.$source), time, calcination temperature etc. The specific area (SA) of CP support of 10 $\mathrm{m}^{2} \cdot \mathrm{g}^{-1}$ is relatively lower than the Ce-Zr solid solution for similar Ce/Zr ratios reported in literature [16, 26, 27]. However, authors of those works used slightly different preparation recipe. For example, $\mathrm{Hu}$ et. al. [27] used $\mathrm{ZrOCl}_{2}$ and $\mathrm{Ce}\left(\mathrm{NO}_{3}\right) \cdot 6 \mathrm{H}_{2} \mathrm{O}$ as precursors, and the support was calcined at only $600{ }^{\circ} \mathrm{C}$ for $6 \mathrm{~h}$. Consequently, the obtained $\mathrm{Ce}_{0.1} \mathrm{Zr}_{0.9} \mathrm{O}_{2}$ oxide has a specific area of $42.97 \mathrm{~m}^{2} / \mathrm{g}$. Biswas and Kunzru [26] also used similar synthesis conditions with higher calcination temperature $\left(750{ }^{\circ} \mathrm{C}\right)$ and they obtained the mixed oxide $\mathrm{Ce}_{0.16} \mathrm{Zr}_{0.84} \mathrm{O}_{2}$ with specific area of $31.1 \mathrm{~m}^{2} \mathrm{~g}^{-1}$. Colon et al. [16] used nitrate precursors, however, the mixed oxide was calcined under $\mathrm{H}_{2} \mathrm{O}$ enriched gas. Therefore, the low specific 
area of CP in this study can be due to experimental synthesis parameters that were used. However, by introducing the subsequent hydrothermal step the specific area of corresponding support (HT) is much improved, from 10 to $53.7 \mathrm{~m}^{2} \mathrm{~g}^{-1}$. This improvement might be due to the conversion of the hydroxide complex to oxide form (the hydroxide complex is formed in the co-precipitation step). Thus, it possibly inhibits the grain growth and fusion of as-prepared hydrated mixed hydroxide during the calcination step at high temperature [28]. Furthermore, the metal deposition and the subsequent thermal treatment steps (e.g., calcination and reduction of metal supported catalyst) have adverse effect on the texture of the catalyst. For example, in deposition of $\mathrm{Ni}$ or $\mathrm{Rh}$ on $\mathrm{CeO}_{2}-\mathrm{ZrO}_{2}$ based supports, loss of $20-33 \%$ specific area was reported elsewhere [26, 27, 29]. In this study, the CP support also experienced severe sintering during deposition and post-treatment of $\mathrm{Ni}$ supported catalyst. Its specific area reduced $\sim 80 \%$ and the pore structure almost collapses. Meanwhile, HT based catalyst lost only about $21 \%$ its original specific area. Therefore, the hydrothermal treatment improved not only the texture of as-prepared support, but also the thermal resistance of the corresponding catalyst.

Table 5.2 also includes the elemental composition of the catalysts, bulk (XRF) and surface (XPS). Since the depth of information in XPS technique is below $3 \mathrm{~nm}$, it is reasonable to consider that the data obtained from XPS as representative for the surface composition. The surface atomic $\mathrm{Ce} / \mathrm{Zr}$ ratios, respectively, for $\mathrm{Ni} / \mathrm{HT}$ and $\mathrm{Ni} / \mathrm{CP}$ are very close to the corresponding ratios in bulk phase as estimated from XRF. This confirms an even distribution of Ceria in the ceria-zirconia solid solution formed in these two cases. The slightly enriched Ceria content on the surface can be due to migration of $\mathrm{Ce}^{4+}$ during reductive treatment [30] or the cover of $\mathrm{Zr}$ site by $\mathrm{Ni}$. In contrast, the surface $\mathrm{Ce} / \mathrm{Zr}$ atomic ratio of $\mathrm{Ni} / \mathrm{IM}$ catalyst is much higher than in the bulk ( 0.51 compared with 0.2$)$. This result is expected since ceria was deposited via impregnation on $\mathrm{ZrO}_{2}$ oxide. The atomic concentration of cerium on the surface is highest in the case of Ni/IM catalyst. XRF analysis found trace amounts of potassium in both $\mathrm{Ni} / \mathrm{CP}$ and $\mathrm{Ni} / \mathrm{HT}$ catalyst which came from ammonia used in the co-precipitation step. However, no potassium was detected by XPS which indicate no presence of potassium on the surface of the catalyst. Thus, these traced amount of potassium is not expected to have any contribution to the differences in activity of the catalysts.

From Table 5.1, it is realised that the weight percentage of $\mathrm{Ni}$ on $\mathrm{Ni} / \mathrm{IM}$ is about $10 \%$ lower than that on Ni/HT (2.9 vs. 3.2 wt.\%). The absolute counts for Ni band in the XPS spectra of $\mathrm{Ni} / \mathrm{IM}$ and $\mathrm{Ni} / \mathrm{HT}$ are 55645 and 48515, respectively. These values are proportional to the Ni content per unit surface area of the catalyst. When the specific area of each catalyst is accounted for (Ni/IM $35.4 \mathrm{~m}^{2} \mathrm{~g}^{-1}$, and Ni/HT $\left.42.2 \mathrm{~m}^{2} \mathrm{~g}^{-1}\right)$ the amounts of Ni on the surface of 
$\mathrm{Ni} / \mathrm{IM}$ and $\mathrm{Ni} / \mathrm{HT}$ are similar. On the other hand, both surface and bulk amounts of $\mathrm{Ni}$ on $\mathrm{Ni} / \mathrm{CP}$ are much lower. Consequently, this can be expected to have a big influence on the activity of the catalyst.

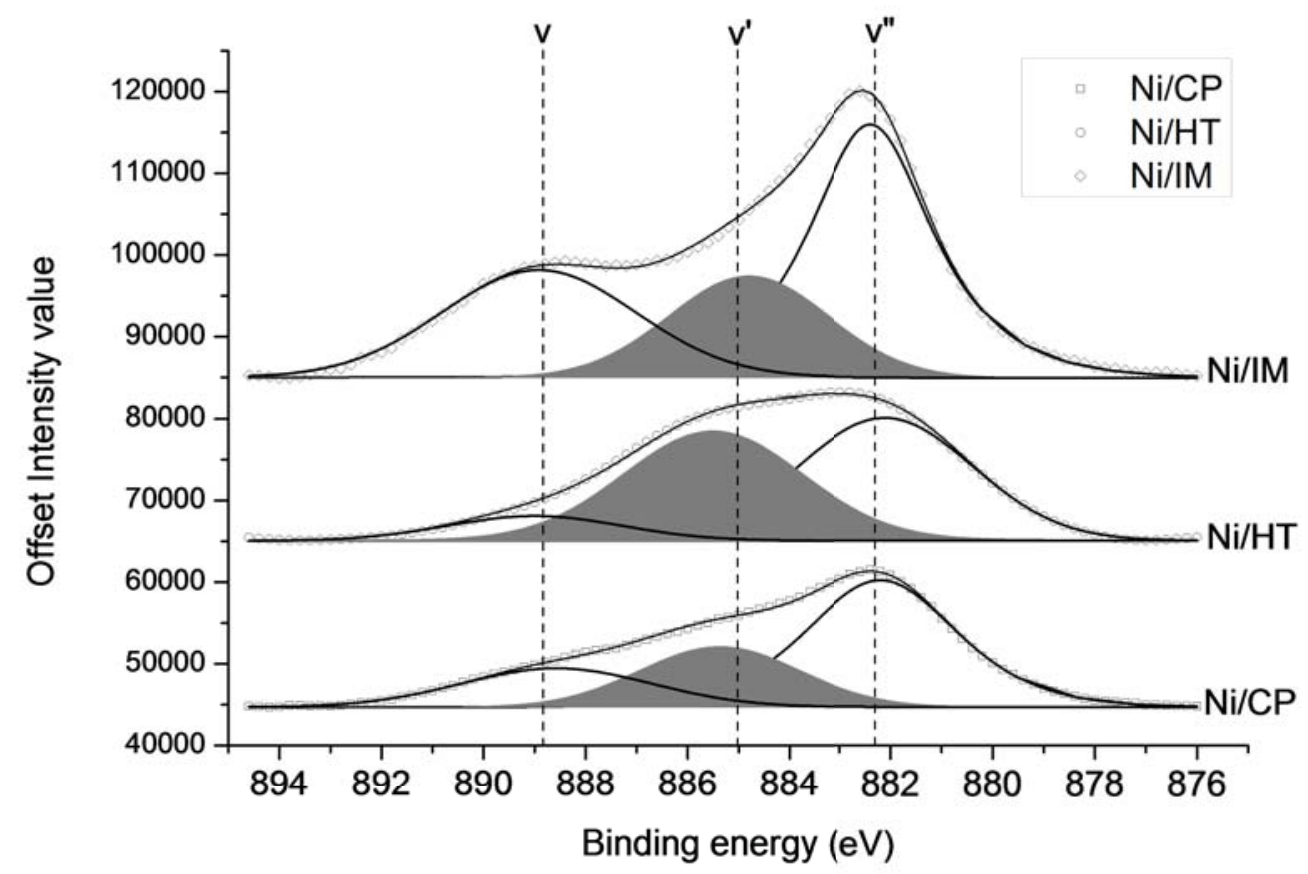

Figure 5.3. XPS Ce $3_{\mathrm{d} 5 / 2}$ spectra of supported Ni catalysts. Area curve filled with grey solid is representative for $\mathrm{Ce}^{3+}$

Table 5.3. Result of the de-convolution of Ce $3 d_{5 / 2}$ XPS bands

\begin{tabular}{|l|c|c|c|c|l|c|}
\hline \multirow{2}{*}{} & \multicolumn{2}{|l|}{$\mathrm{v}=882.25 \pm 0.0 .15(\mathrm{eV})$} & \multicolumn{2}{l|}{$\mathrm{v}^{\prime}=885.15 \pm 0.35(\mathrm{eV})$} & \multicolumn{2}{l|}{$\mathrm{v}^{\prime \prime}=888.7 \pm 0.2(\mathrm{eV})$} \\
\cline { 2 - 7 } & Area & Area \% & Area & Area \% & Area & Area \% \\
\hline $\mathrm{Ni} / \mathrm{CP}$ & 61185 & 54.3 & 29196 & 25.9 & 22265 & 19.8 \\
\hline $\mathrm{Ni} / \mathrm{HT}$ & 64596 & 47.4 & 58637 & 43.1 & 12957 & 9.5 \\
\hline $\mathrm{Ni} / \mathrm{IM}$ & 106305 & 48.8 & 48956 & 22.5 & 62502 & 28.7 \\
\hline
\end{tabular}

In addition, XPS can also help to understand the surface chemical state of cerium in the catalysts. Figure 5.3 shows the XPS $\mathrm{Ce} 3 \mathrm{~d}_{5 / 2}$ core-level spectra of the catalysts and corresponding de-convolution curves. The experimental photo emission band of $\mathrm{Ce} 3 \mathrm{~d}_{5 / 2}$ were 
de-convoluted into three peaks and denoted as: v $(882.25 \pm 0.0 .15 \mathrm{eV}), \mathrm{v}^{\prime}(885.15 \pm 0.35 \mathrm{eV})$ and $v^{\prime \prime}(888.7 \pm 0.2 \mathrm{eV})$ according to Laachir et al. [31], Pfau and Schierbaum [32]. X-ray satellites and the Shirley background were subtracted prior to de-convolution. $\mathrm{v}$ and $\mathrm{v}^{\prime \prime}$ are assigned to mixing of the $3 \mathrm{~d}^{9} 4 \mathrm{f}^{2} \mathrm{~V}^{\mathrm{n}-2}$ and $3 \mathrm{~d}^{9} 4 \mathrm{f}^{1} \mathrm{~V}^{\mathrm{n}-1} C \mathrm{e}^{4+}$ state. $\mathrm{v}^{\prime}$ is attributed to $3 \mathrm{~d}^{9} 4 \mathrm{f}^{1} \mathrm{~V}^{\mathrm{n}}$ $\mathrm{Ce}^{3+}$ state. These assignments are in accordance with reported literature [31-33]. Quantitative determination of $\mathrm{Ce}^{3+}$ concentrations is realized from area percentage of $\mathrm{v}^{\prime}$ band and summarized in Table 5.3. It is easily recognized that $\mathrm{Ce}^{3+}$ concentration/amount is the highest in $\mathrm{Ni} / \mathrm{HT}$ among the three catalysts. It should be remarked that there is high chance that the samples are re-oxidised due to exposing to ambient condition when they were transferred from reactor to container vials as well as during the sample deposition on Ir foil for XPS measurement. Thus, the oxidation state of $\mathrm{Ce}$ is investigated further by using TPR analysis.

The temperature programed reduction profiles of the catalysts and the corresponding supports are shown in Figure 5.4. The $\mathrm{H}_{2}$ uptake and other related details are given in Table 5.4. The TPR curve of IM support shows only a small peak at ca. $650{ }^{\circ} \mathrm{C}$. The $\mathrm{H}_{2}$ uptake during reduction of IM support is much lower (see Table 5.4) than that required for full/bulk reduction of $\mathrm{Ce}^{4+}$ to $\mathrm{Ce}^{3+}$. It is reported that bulk $\mathrm{Ce}^{4+}$ is reduced only at elevated temperature, above $850{ }^{\circ} \mathrm{C}[29,34]$. However, another reduction peak in the range of 450 to 750 ${ }^{\circ} \mathrm{C}$ is reported for pure ceria, depending on the size and morphology of the ceria particles. This is often attributed to reduction of $\mathrm{Ce}^{4+}$ at the surface $[26,34]$. Therefore, the low $\mathrm{H}_{2}$ uptake in the reduction of IM support (at $650{ }^{\circ} \mathrm{C}$ ) indicates presence of ceria as a separate phase and the reduction peak corresponds to $\mathrm{Ce}^{4+}$, probably present at the external surface of Ce particles or Ce in the vicinity of $\mathrm{ZrO}_{2}$. CP and HT support shows a major peak at $\sim 700{ }^{\circ} \mathrm{C}$ and $500{ }^{\circ} \mathrm{C}$, respectively, where it was shown earlier that ceria is distributed well in the zirconia phase forming solid solutions. The reduction temperature of these oxide solutions are in the same temperature range reported for

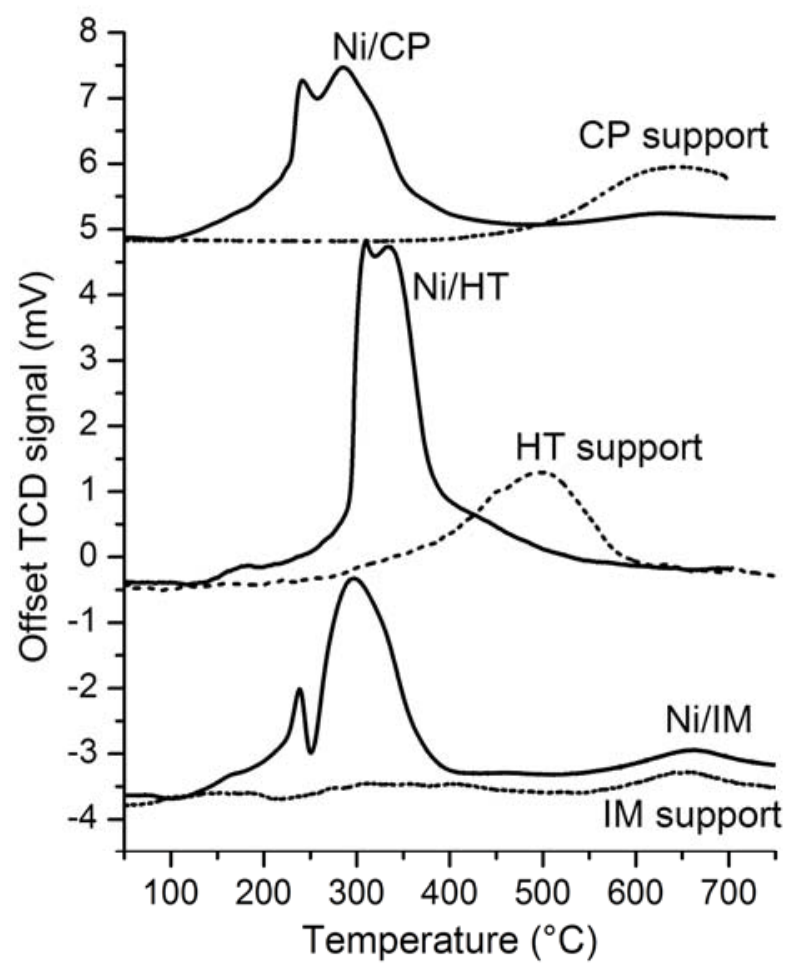

Figure 5.4. TPR of Ce-Zr supports and corresponding catalysts supported $\mathrm{Ni}$ 
ceria-zirconia solid solutions with similar $\mathrm{Ce} / \mathrm{Zr}$ ratios $[15,35]$. The lower reduction temperature of HT support compared with $\mathrm{CP}$ support can be due to increase of cerium content in the support $[15,34]$. The percentage of $\mathrm{Ce}^{3+}$ in CP support is higher than that in HT support, 91 compared to $79 \%$, respectively (Table 5.4). These high $\mathrm{Ce}^{3+}$ contents indicates that the reduction also takes place in the bulk phase of the mixed oxides.

Table 5.4. $\mathrm{H}_{2}$ consumption during TPR analysis

\begin{tabular}{|c|c|c|c|c|}
\hline \multirow{2}{*}{$\begin{array}{l}\text { Sample } \\
\text { ID }\end{array}$} & \multicolumn{2}{|c|}{ Theoretical $\mathrm{H}_{2}$ uptake (m mol/g sample) } & \multirow{2}{*}{$\begin{array}{c}\text { TPR } \mathrm{H}_{2} \text { uptake } \\
\text { (m mol/g sample) }\end{array}$} & \multirow{2}{*}{$\begin{array}{c}\mathrm{Ce}^{3+} / \text { total Ce } \\
\%\end{array}$} \\
\hline & $\mathrm{Ce}^{4+} \rightarrow \mathrm{Ce}^{3+}\left(\mathrm{U}_{\mathrm{Ce}}\right)$ & $\mathrm{Ni}^{2+} \rightarrow \mathrm{Ni}^{0}\left(\mathrm{U}_{\mathrm{Ni}}\right)$ & & \\
\hline $\mathrm{CP}$ & 0.43 & - & 0.39 & 91 \\
\hline $\mathrm{HT}$ & 0.62 & - & $0.49 \pm 0.02$ & $79 \pm 3.2$ \\
\hline IM & 0.646 & - & 0.05 & 7.8 \\
\hline $\mathrm{Ni} / \mathrm{CP}$ & 0.42 & 0.23 & 0.65 & 100 \\
\hline $\mathrm{Ni} / \mathrm{HT}$ & 0.59 & 0.55 & $1.02 \pm 0.04$ & $80 \pm 6.7$ \\
\hline $\mathrm{Ni} / \mathrm{IM}$ & 0.62 & 0.47 & $0.83 \pm 0.1$ & $58 \pm 16$ \\
\hline \multicolumn{5}{|c|}{$\begin{array}{l}\text { Note: Composition of } \mathrm{Ce}^{3+} \text { is estimated based on the following equation: } \\
\mathrm{Ce}^{3+}(\%)=100 \% \times \frac{U_{T P R}-U_{N i}}{U_{C e}} \text { [where } U_{T P R}, U_{C e}, U_{N i} \text { is } \mathrm{H}_{2} \text { uptake in TPR experiment, the } \\
\text { theoretical } \mathrm{H}_{2} \text { uptake for reduction of } \mathrm{Ni}^{2+}\left(\text { to } \mathrm{Ni}^{0}\right) \text { and } \mathrm{Ce}^{4+}\left(\text { to } \mathrm{Ce} e^{3+}\right) \text {, respectively] } \\
\text { Assume that besides the reduction of } \mathrm{Ni}, \mathrm{H}_{2} \text { uptake is only consumed for the following } \\
\text { reaction: } 2 \mathrm{CeO}_{2}+\mathrm{H}_{2} \rightarrow \mathrm{Ce}_{2} \mathrm{O}_{3}+\mathrm{H}_{2} \mathrm{O}\end{array}$} \\
\hline
\end{tabular}

The TPR patterns of the catalysts containing $\mathrm{Ni}$ are different from those of the corresponding supports. In all cases two reduction peaks are observed, differing in intensities as well as temperature. These reduction peaks appear below $400{ }^{\circ} \mathrm{C}$. Reduction is initiated at relatively lower temperatures $\left(125-150^{\circ} \mathrm{C}\right)$ and the reduction peaks are broad mean while uptake of $\mathrm{H}_{2}$ at low temperature is not seen in reduction of bare supports. These two phenomena are often attributed to interaction between transition metal (i.e, $\mathrm{Ni}$ in this case) and ceria based support [36]. Reducibility of Ni is facilitated in the case of being supported on $\mathrm{CeO}_{2}$ or $\mathrm{Ce}-\mathrm{Zr}$ oxide $[13,36]$. The uptake of $\mathrm{H}_{2}$ at relatively low temperature (onset at 125 $\left.{ }^{\circ} \mathrm{C}\right)$ is attributed to the spill-over of $\mathrm{H}_{2}$ on the support $[37,38]$. This phenomenon requires the presence of a metal to activate $\mathrm{H}_{2}$ [37]. Furthermore, the interaction between $\mathrm{Ni}$ and $\mathrm{CeO}_{2}$ may help with reducing $\mathrm{Ce}^{4+}$ species not only those on the surface but also those located inside the lattice. The reducibility of ceria by $\mathrm{H}_{2}$ in general associates with the oxygen storage capacity of the catalyst support. According to the estimation of $\mathrm{H} 2$ uptake from Table 5.4, $\mathrm{Ni} / \mathrm{HT}$ catalyst potentially has highest amounts of oxygen vacancies among three catalysts due to the amount of reducible $\mathrm{Ce}^{4+}$, thus maximising the redox capacity of the catalyst. 


\subsubsection{Catalytic tests}
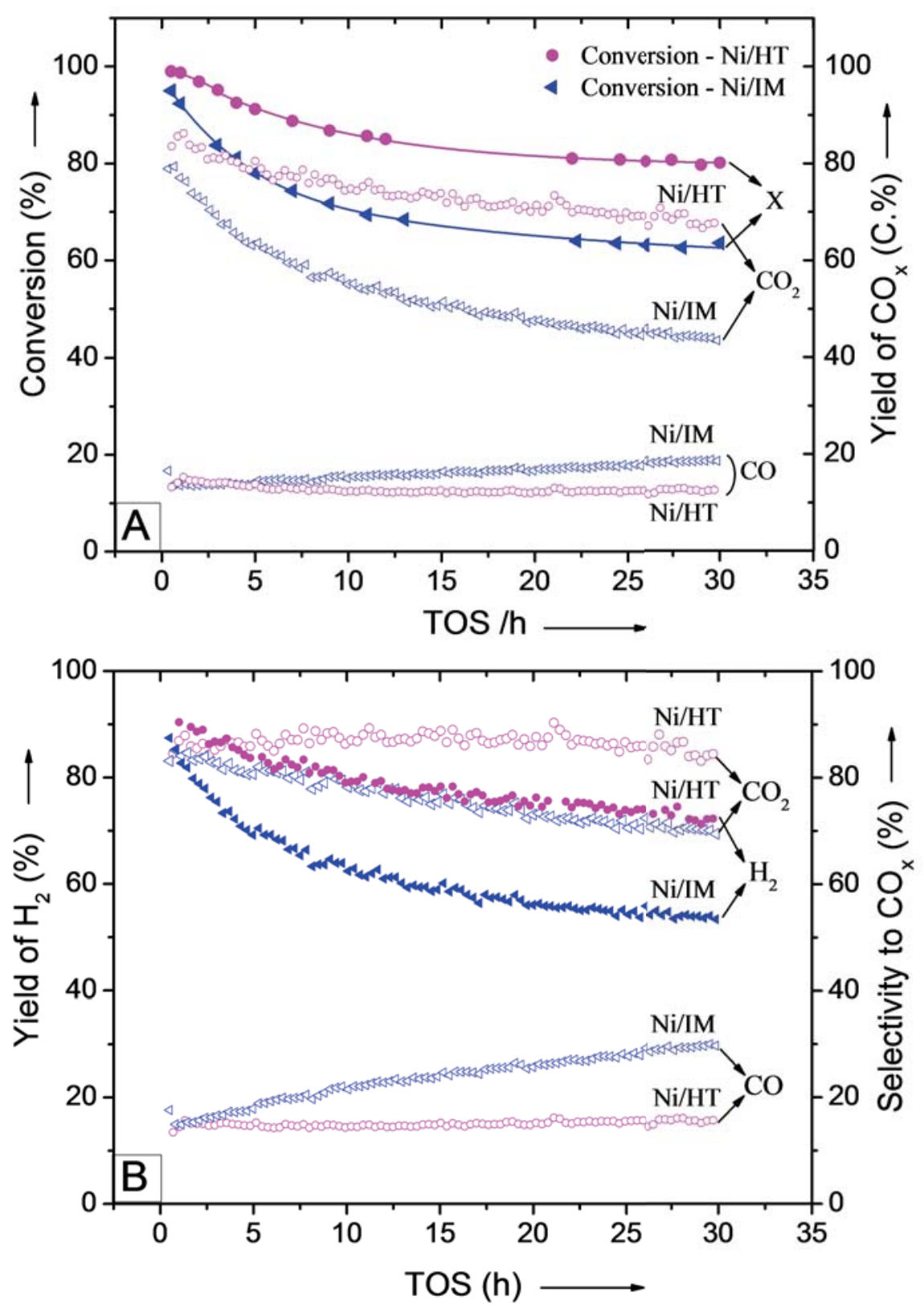

Figure 5.5. Catalytic steam reforming of $m$-cresol using $\mathrm{Ni} / \mathrm{HT}$ and $\mathrm{Ni} / \mathrm{IM}$ catalysts: conversion of $m$-cresol and yield of $\mathrm{CO}_{\mathrm{x}}(\mathrm{A})$; yield of $\mathrm{H}_{2}$ and selectivity to $\mathrm{CO}_{\mathrm{x}}(\mathrm{B})$. Reaction condition: $700{ }^{\circ} \mathrm{C}, \mathrm{S} / \mathrm{C} \sim 43 / 1$, WHSV $7.89 \mathrm{~h}^{-1}$ (Solid labels represent conversion or yield of $\mathrm{H}_{2}$, open symbol represents yield or selectivity of $\mathrm{CO}_{\mathrm{x}}$, result of $\mathrm{Ni} / \mathrm{HT}$ in magenta and that of $\mathrm{Ni} / \mathrm{IM}$ in blue)

Among the three catalysts, Ni/CP has the lowest Ni content, low surface area and correspondingly showed low catalytic activity. It also deactivated severely, losing $>60 \%$ activity during an 8 hour time on stream. This catalyst was not investigated further. Figure 
5.5 shows the results of steam reforming of $m$-cresol using Ni/HT and Ni/IM catalysts during $30 \mathrm{~h}$ TOS. The products identified in the case of $m$-cresol reforming were phenol, benzene, toluene, $\mathrm{CO}, \mathrm{CO}_{2}$ and hydrogen. Both catalysts give very high initial conversion of $m$-cresol, $98 \%$ and $95 \%$ for $\mathrm{Ni} / \mathrm{HT}$ and $\mathrm{Ni} / \mathrm{IM}$, respectively (Figure 5.5-A). The main products were $\mathrm{CO}, \mathrm{CO}_{2}, \mathrm{H}_{2}$ and trace amounts of phenol (yield below 0.1\%). The initial selectivities (Figure 5.5-B) towards $\mathrm{CO}_{2}$ and $\mathrm{CO}$ of both catalysts are similar: $\mathrm{CO}_{2} \sim 85 \%$ and $\mathrm{CO} \sim 15 \%$ in carbon basis. The corresponding initial hydrogen yields are $89 \%$ and $87 \%$ when using Ni/HT and Ni/IM, respectively. The conversion of $m$-cresol gradually decreases (Figure 5.5-A) in both cases over 25 hour TOS and then the conversion levels off/stabilize, showing partial deactivation. The drop in conversion for Ni/IM catalyst is higher than that for Ni/HT catalyst (Ni/HT from $99 \%$ to $80 \%$; Ni/IM from $95 \%$ to $63 \%$ after $30 \mathrm{~h}$ TOS). There is also a corresponding decrease in yields of gaseous products. Surprisingly, the product selectivities to $\mathrm{CO}_{2}$ and $\mathrm{CO}$, in the case of Ni/HT, remain almost constant. For Ni/IM catalyst, selectivities vary with time; $\mathrm{CO}$ increases from $14.9 \%$ to $29.7 \%$ and $\mathrm{CO}_{2}$ decrease from $85.1 \%$ to $69.1 \%$ after $30 \mathrm{~h}$ TOS. Carbon balance of $100 \pm 3 \%$ was achieved during all the kinetic experiments. Due to the different variations in selectivities for $\mathrm{CO}_{\mathrm{x}}$ with time, and loss of conversion caused by deactivation, $\mathrm{H}_{2}$ yields for Ni/HT decreases less appreciably than Ni/IM. Thus among the three catalysts, Ni/HT also shows the most promise.

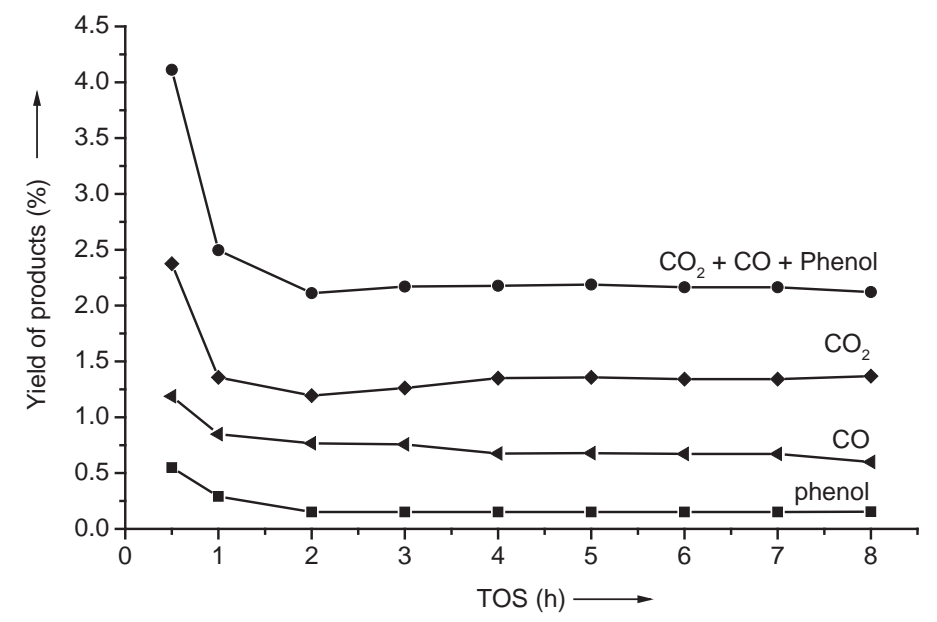

Figure 5.6. Yield of products from reforming of $m$-cresol on bare HT support. Reaction condition: $700{ }^{\circ} \mathrm{C}, \mathrm{S} / \mathrm{C} \sim 43 / 1$, WHSV $7.89 \mathrm{~h}^{-1}$

The identified products in steam reforming of $m$-cresol using bared HT support are illustrated in Figure 5.6. The HT support already exhibits some initial activity for the decomposition/reforming of $m$-cresol. This activity decreased rapidly within the first hour then reached steady state after $2 \mathrm{~h}$ TOS. For example, phenol yield dropped from $0.5 \%$ at 0.5 $\mathrm{h}$ to $0.15 \%$ and continued at this level. Similar observation can also be made in the case of 
$\mathrm{CO}$ and $\mathrm{CO}_{2}$. Benzene and toluene were not observed in these experiments. These results imply the activation of $m$-cresol on the support. It should be noted that the yields of phenol, benzene, toluene or $\mathrm{CO}_{\mathrm{x}}$ were negligible (e.g., phenol $0.03-0.08 \%$ ) in thermal steam reforming (in the absence of a catalyst). Therefore, the yields of $\mathrm{CO}_{\mathrm{x}}$ when reaction reaches to steady state (i.e. after $2 \mathrm{~h}$ TOS) are attributed to a combination of the residual activity of the support and the coke deposits on the support.

\subsubsection{Characterisation of coke deposits on used catalysts}

The nature of the coke deposited on used catalysts was investigated by Raman spectroscopy. Figure 5.7 shows the primary order Raman spectra of coke normalized with respect to the band at $1595 \mathrm{~cm}^{-1}$ (G-band). It can be seen that Raman spectra of coke deposited on supports contain two broad and strongly overlapping peaks, at $\sim 1350$ $\mathrm{cm}^{-1}$ (D-band) and at $1595 \mathrm{~cm}^{-1}$. With regard to relatively low oxidation temperature of these cokes

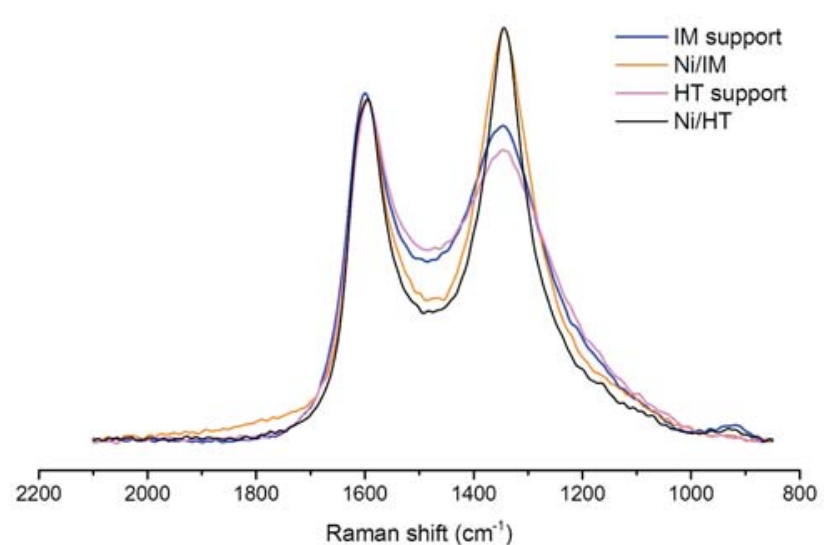

Figure 5.7. Raman spectroscopy of coke deposited on catalysts. Spectra were normalized to $\mathrm{G}$ band at $1595 \mathrm{~cm}^{-1}$ (310-321 ${ }^{\circ} \mathrm{C}$, from TPO - Figure

5.8), these two bands cannot be assigned to graphitic crystallite structures or disordered graphite. The $G$ band here can be due to the aromatic ring breathing [39] or the bond stretching of all pairs of $\mathrm{sp}^{2}$ carbon [40] (in both rings and chains). The $\mathrm{D}$ band corresponds to the breathing mode of $\mathrm{sp}^{2} \mathrm{C}$ in (poly)aromatic rings [39-41]. The Raman spectra of coke deposited on both Ni-supported catalysts (Ni/HT and Ni/IM) exhibit similar shapes. Compared with the Raman spectra of coke deposited on bare support, both D and G bands of the Raman spectra of coke on supported Ni catalysts are sharper with narrower line-width. It is also apparent that $\mathrm{D}$ band to $\mathrm{G}$ band intensity ratios $\left(\mathrm{I}_{\mathrm{D}} / \mathrm{I}_{\mathrm{G}}\right)$ of the coke on Ni catalysts increases compared to bare supports. The differences in Raman spectra, together with slightly higher oxidation temperature indicate increase in order of the carbon based structure in the case of supported Ni catalysts. This also implies lower hydrogen content and increases of ring concentration in coke deposited on supported Ni catalysts compared with coke on bare support. Coke formed during steam reforming of $m$-cresol using bare supports might be due to decomposition/condensation of $m$-cresol, resulting in probably poly-aromatic type carbon. As 
$\mathrm{Ni}$ is capable of disassociating $\mathrm{C}-\mathrm{C}$ or $\mathrm{C}-\mathrm{H}$ bonds of $m$-cresol, the coke formed in the presence of Ni-catalyst might be result of recombination of intermediates formed on metal surface. Therefore, more graphitised coke is expected.

The quantification of coke deposited on the catalysts during steam reforming of $m$-cresol was achieved by TPO which is illustrated Figure 5.8. In the case of only supports, the amount of coke was higher for HT than that on IM support $(\mathrm{C}$ $4.2 \mathrm{wt} \%$ vs. C $2.9 \mathrm{wt} \%)$. This implies that the adsorption of $m$-cresol is more enhanced on HT than on IM. This will be shown and discussed in the next section on probing the

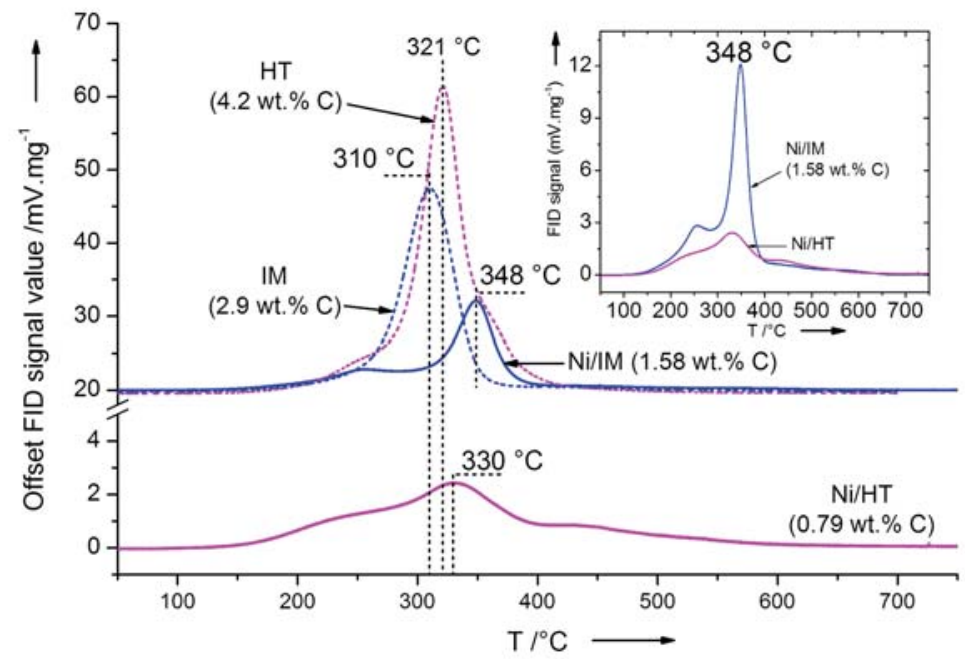

Figure 5.8. TPO of used catalysts and supports after steam reforming of $m$-cresol. Inset: close up TPO of $\mathrm{Ni} / \mathrm{HT}$ vs. Ni/IM

reforming steps by in situ FT-IR. Nevertheless, the coke formation on supported Ni catalysts was lower but shows the opposite trend. The amount of carbon deposited on Ni/HT $(0.79$ wt.\%) is half of that on Ni/IM (1.58 wt.\%). Albeit its higher surface cerium content, the latter catalyst (Ni/IM) has lower amount of $\mathrm{Ce}^{3+}$ (according to TPR result). Under steam reforming conditions, the support can be re-oxidised by $\mathrm{H}_{2} \mathrm{O}$ or $\mathrm{CO}_{2}$. Thus, higher reducible oxygen capacity can be achieved with $\mathrm{Ni} / \mathrm{HT}$ catalyst. In addition, HT also shows the lowest reduction temperature among those supports, which correlates to more facile removal of oxygen on the support lattice. Together, the higher amount of labile oxygen can enhance the oxidation of the coke or the carbon amounts deposited on the catalyst under reforming condition. Therefore, it can explain the lower coke content on the used Ni/HT catalyst. The presence of coke on supported $\mathrm{Ni}$ catalysts is one of the causes of deactivation of the catalysts. In agreement, $\mathrm{Ni} / \mathrm{HT}$ catalyst shows the lowest extent of deactivation, and most promise for steam reforming of $m$-cresol.

\subsubsection{In situ FT-IR of steam reforming of $m$-cresol on HT and IM based catalysts}

FT-IR spectroscopy was employed to investigate the interaction of $m$-cresol with catalyst and the subsequent steam reforming steps. In order to observe the interaction of the reactants with the support, a titration-type reforming experiment was carried out in FT-IR cell. 


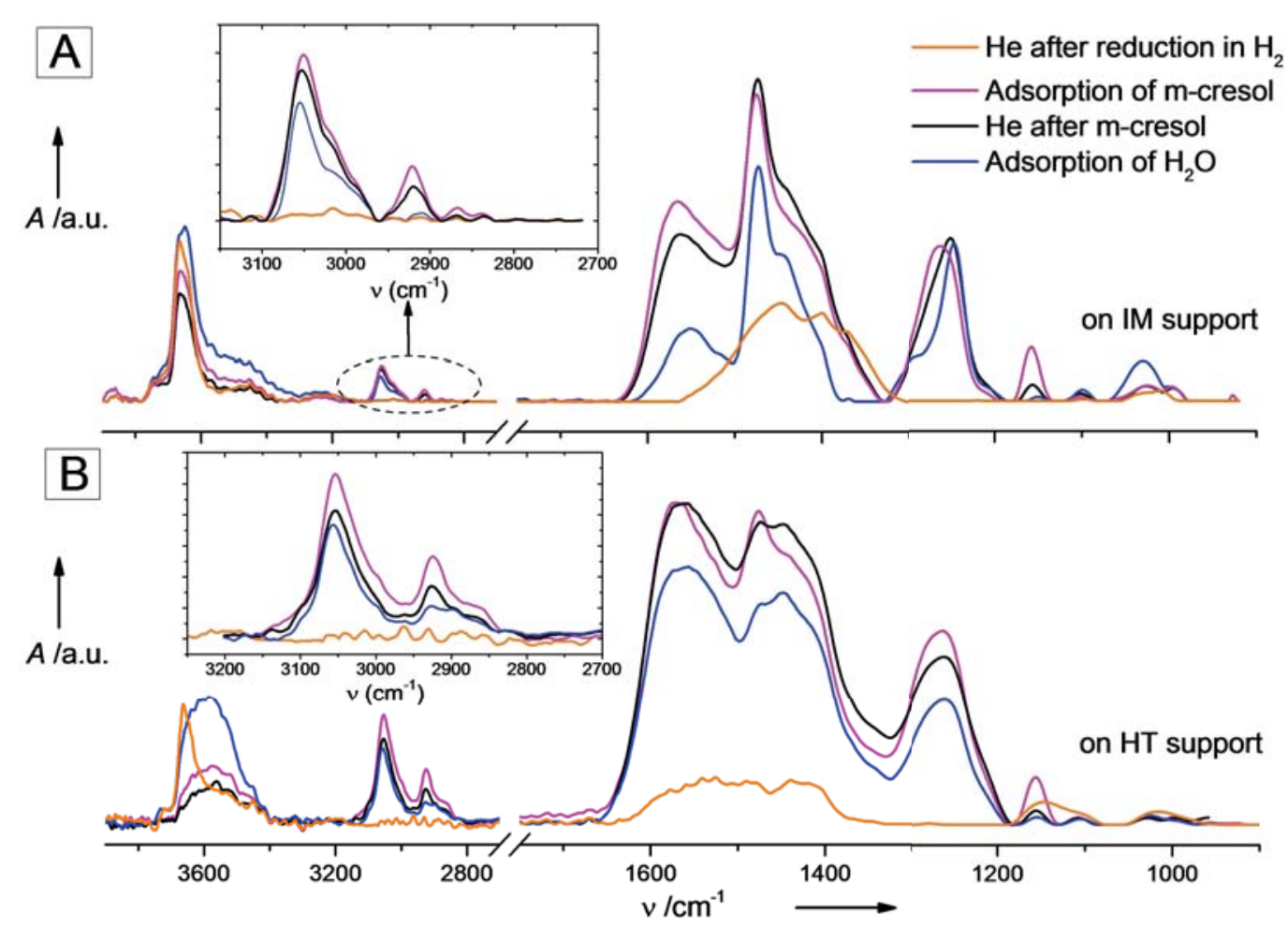

Figure 5.9. FT-IR spectra under titration mode for the steam reforming of m-cresol on IM (A) and HT (B)

The self-supporting discs of catalysts were first reduced in 10 vol. $\% \mathrm{H}_{2} / \mathrm{He}$ at $450{ }^{\circ} \mathrm{C}$ for an hour and then the IR cell was evacuated in He. For the reforming steps, catalyst discs were exposed to He containing each reactant (first $m$-cresol then $\mathrm{H}_{2} \mathrm{O}$ ) for $1 \mathrm{~h}$; the two steps are separated by an evacuation step for 30 minutes in He to remove weakly or physically adsorbed species. Figures 5.9 - A, B represent the IR spectra recorded at the end of each step. Both IM and HT supports exhibit two set of peaks prior to adsorption of $m$-cresol: (i) $\mathrm{O}-\mathrm{H}$ stretching, $v_{\mathrm{OH}}\left(3800-3200 \mathrm{~cm}^{-1}\right)$ and (ii) $\mathrm{C}-\mathrm{O}$ stretching $\left(v_{\mathrm{CO}}\right)$ in carbonate or carboxylate between 1600 and $1300 \mathrm{~cm}^{-1}$ [42]. In the $v_{\mathrm{OH}}$ range, the spectra of both supports show strong peak at $3664 \mathrm{~cm}^{-1}$, which is assigned to tri-bridging hydroxyls and a broad band in the range of $3500-3300 \mathrm{~cm}^{-1}$ which corresponds to hydrogen bridging hydroxyls. In addition, in the case of IM support, the main peak at $3664 \mathrm{~cm}^{-1}$ has a small shoulder at $\sim 3745 \mathrm{~cm}^{-1}$ which may be attributed to low coordinated hydroxyl of $m-\mathrm{ZrO}_{2}$ [43]. For the HT support, the spectral $v_{\mathrm{OH}}$ range consists a weak peak at $3721 \mathrm{~cm}^{-1}$ which may be tentatively assigned to bi-bridging $\mathrm{OH}$ [44]. IR spectrum of reduced $m-\mathrm{ZrO}_{2}$ does not exhibit any clear peaks in the $v_{\mathrm{CO}}$ range (not shown here). This is in agreement with the literatures on reduced $\mathrm{ZrO}_{2}$ reported elsewhere [45]. Therefore, presence of $v_{\mathrm{CO}}$ in the IR spectra of both supports can be mainly 
associated with the ceria fraction of the support. The peak in $v_{\mathrm{CO}}$ band of IM support centres at $1450-1375 \mathrm{~cm}^{-1}$ which mainly represents polydentate carbonate stretching $\left(1462 \mathrm{~cm}^{-1}\right.$, $1351 \mathrm{~cm}^{-1}$ ) [46]. On the other hand, the $v_{\mathrm{CO}}$ band of HT support spreads the range $1600-$ $1400 \mathrm{~cm}^{-1}$ which comprises band of bi-dentate $\left(1567 \mathrm{~cm}^{-1}\right)$, mono-dentate $\left(1504 \mathrm{~cm}^{-1}\right)$ and bicarbonate $\left(1414 \mathrm{~cm}^{-1}\right)$.

The spectra of support after adsorption of $m$-cresol vapour as well as the subsequent exposure to steam consist of three distinct sets of peaks: (i) $\mathrm{O}-\mathrm{H}$ stretching vibration $\left(\mathrm{v}_{\mathrm{OH}}\right)$ between 3750 and $3200 \mathrm{~cm}^{-1}$, (ii) C-H stretching vibration $\left(v_{\mathrm{CH}}\right)$ between 3100 and $2800 \mathrm{~cm}^{-1}$ and (iii) the set between 1600 and $1000 \mathrm{~cm}^{-1}$. The last set contains a complex combination of multiple vibrations including skeletal aromatic ring stretching, $\mathrm{C}-\mathrm{O}$ stretching $\left(v_{\mathrm{CO}}\right)$, alkyl deformation etc. Discussing in detail what occurs during each reaction step is beyond the purpose of this chapter. However, the apparent differences in relative intensities of the main peaks (e.g., $v_{\mathrm{CH}}$ vs. peak at $\sim 1570 \mathrm{~cm}^{-1}$ or peak at $1475 \mathrm{~cm}^{-1}$ ) implies different reaction pathways occurring on these supports. The assignments for the main peaks of IR spectra is summarised in Table 5.5.

Table 5.5. Peak assignment of FT-IR spectra of reforming $m$-cresol on Ce-Zr oxide

\begin{tabular}{|c|c|c|c|c|}
\hline \multicolumn{2}{|c|}{ IM } & \multicolumn{2}{|c|}{ HT } & \multirow{2}{*}{ Assignment } \\
\hline Peak $\left(\mathrm{cm}^{-1}\right)$ & Intensity & Peak $\left(\mathrm{cm}^{-1}\right)$ & Intensity & \\
\hline 3745 & $\mathrm{~W}$ & & & Terminated $v_{\mathrm{OH}}$ \\
\hline 3721 & $\mathrm{~W}$ & 3721 & $\mathrm{~W}$ & Bi-bridge $v_{\mathrm{OH}}$ \\
\hline 3645 & $\mathrm{~S}$ & 3645 & $\mathrm{~s}$ & Tri-bridge $v_{\mathrm{OH}}$ \\
\hline $3300-3500$ & $\mathrm{~b}$ & $3300-3500$ & $\mathrm{~b}$ & Hydogen bond $\mathrm{OH}$ \\
\hline 3050 & $\mathrm{~m}$ & 3052 & $\mathrm{~m}$ & $v_{\mathrm{C}-\mathrm{H}}$ of aromatic ring \\
\hline 2921 & $\mathrm{~W}$ & 2925 & $\mathrm{mw}$ & $v_{\mathrm{CH} 3 \text { asym }} / v_{\mathrm{CH} 2 \text { asym }}$ \\
\hline 2867 & $\mathrm{vW}$ & 2860 & sh & $v_{\mathrm{CH} 3 \mathrm{sym}} / v_{\mathrm{CH} 2 \mathrm{asym}}$ \\
\hline $1540-1565$ & $\mathrm{~s}$ & $1556-1575$ & vs & $\phi$ (quadrant stretching of the ring) \\
\hline $1471-1473$ & vS & $1473-1477$ & $\mathrm{~S}$ & $\begin{array}{l}\delta_{\text {ring } \mathrm{C}=\mathrm{C}} \text { (Semicircle stretching of ring } \\
\mathrm{C}=\mathrm{C} \text { mix } \mathrm{CH} \text { bending) }\end{array}$ \\
\hline \multirow[t]{2}{*}{$1440-1446$} & $\mathrm{sh}$ & 1446 & vs & $\delta_{\mathrm{CH} 3}$ or $\delta_{\mathrm{CH} 2}$ (alkyl deformation) \\
\hline & & 1365 & sh & $\delta_{\mathrm{OH}}(\mathrm{OH}$ deformation $)$ \\
\hline $1240-1290$ & $\mathrm{~S}$ & $1260-1280$ & VS & $v_{\mathrm{C}-\mathrm{O}}$ \\
\hline \multicolumn{5}{|c|}{$\begin{array}{l}\text { Note: } \\
\text { w : week; s: strong; b: broaden, m: medium; vw: very week, vs: very strong, sh: on } \\
\text { shoulder }\end{array}$} \\
\hline
\end{tabular}

The spectra recorded after outgassing the $m$-cresol adsorbed on support surface represent the chemisorbed $m$-cresol or intermediates on the supports. It is clearly observed 
that the $v_{\mathrm{C}-\mathrm{H}} / \phi$ (peak at $3052 \mathrm{~cm}^{-1} v s$. peak at $1575 \mathrm{~cm}^{-1}$, respectively) intensity ratio of IM is much lower than that of HT. This can indicate the orientation of adsorbed molecules on the surface. When the aromatic rings are adsorbed in parallel direction on the surface, the $\mathrm{H}$ can interact with $\mathrm{OH}$ or carbonate groups on the support surface via hydrogen bonds. This would hinder the $\mathrm{C}-\mathrm{H}$ stretching vibrations $\left(3052 \mathrm{~cm}^{-1}\right)$, thus leading to lower the $v_{\mathrm{C}-\mathrm{H}} / \phi$ ratio. In contrast, when $m$-cresol is adsorbed perpendicularly on the support via the phenol group or methylene group, hydrogen bond between the groups on support surface and $\mathrm{H}$ of the ring is minimised. The comparison of IR spectra of $m$-cresol adsorbed on the two supports as well as the ATR-IR spectrum of free liquid $m$-cresol in the low wavenumber range is shown in Figure 5.10. All the spectra have been normalised to the intensity of the band near $1600 \mathrm{~cm}^{-1}$. It can be seen that the spectral pattern of HT resemble more closely to that of free $m$-cresol. In addition, it is noticeable that the band at $\sim 1350 \mathrm{~cm}^{-1}$ of free $m$-cresol, which is assigned to deformation vibration of $\mathrm{OH}$ group $\left(\delta_{\mathrm{OH}}\right)$ is absent in the spectrum of IM while it is present in the spectrum for HT. This implies that de-protonation of OH takes place on IM support to form an adsorbed phenolate and in the case of HT support the phenolic group remains intact. Increasing of electronegativity of the $\mathrm{O}$ containing substitute (phenolate) also enhances the intensity of the $v_{\mathrm{C}-\mathrm{O}}[47,48]$ and the $\delta_{\text {ring } \mathrm{C}=\mathrm{C}}[42]$. The spectrum of IM is in agreement with these arguments. It is concluded that $m$-cresol adsorbs perpendicularly on HT support surface probably via methylene group mainly while it favours the adsorption through $\mathrm{OH}$ group on the IM surface, orienting the ring in parallel with the surface.

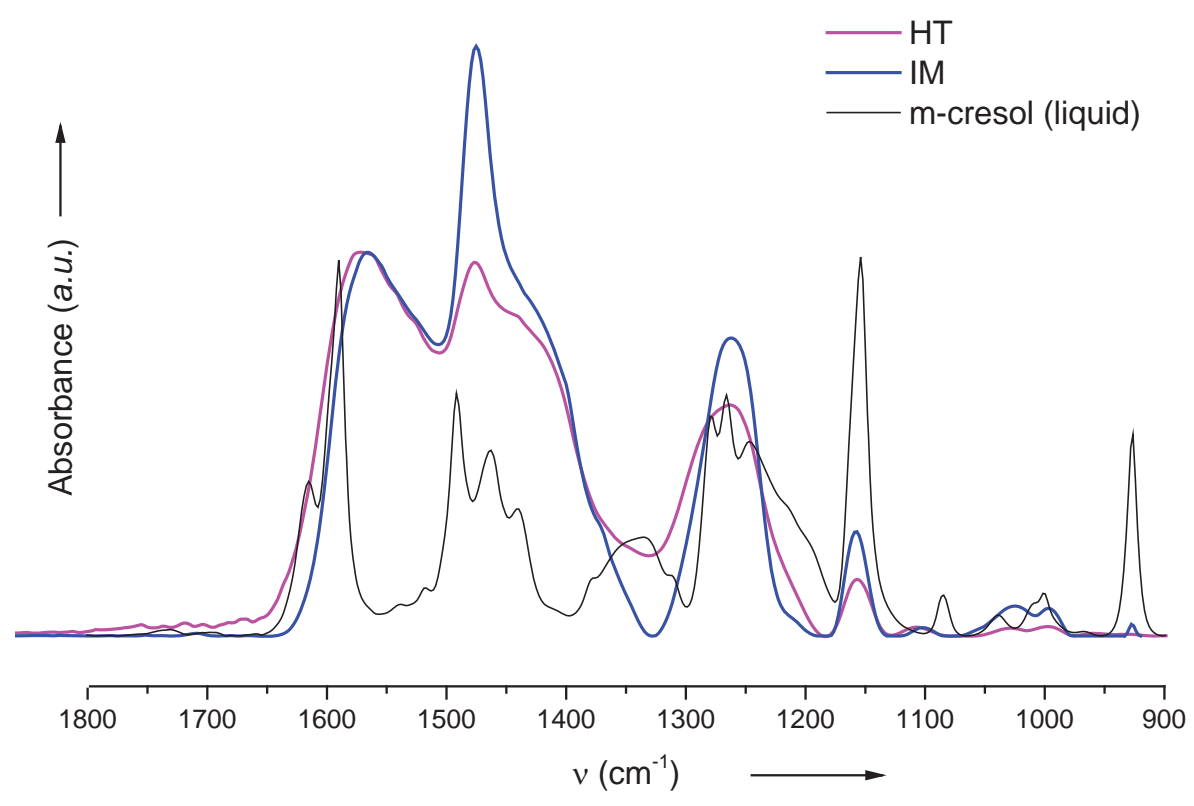

Figure 5.10. Comparison of adsorbed $m$-cresol on IM and HT support with pure $m$ cresol at $21{ }^{\circ} \mathrm{C}$. The spectra are normalised to the peak at $\sim 1590 \mathrm{~cm}^{-1}$ 
For HT support, after an hour exposing to steam (the blue lines in Figure 5.9), the intensity of $\mathrm{C}-\mathrm{H}$ stretching of alkyl group reduce the most while other major vibration intensities of adsorbed species (e.g., $\left.v_{\mathrm{C}-\mathrm{H} \text { ring }}, \phi, \delta_{\text {ring } \mathrm{C}=\mathrm{C}}, v_{\mathrm{C}-\mathrm{O}}\right)$ decrease with similar relative ratio. This result suggests that under steam reforming conditions, some adsorbed methyl(ene) groups changed, which could be oxidised, and the rest of these species (the ring and $\mathrm{OH}$ group) desorbed together. On the other hand, for IM support, during steam reforming step, the intensity of C-O stretching vibration $\left(1245 \mathrm{~cm}^{-1}\right)$ remains constant. Thus the anchoring point of m-cresol on IM support via phenolate group is stable. In contrast, the $\mathrm{C}-\mathrm{H}$ stretching for methyl(ene) vanishes and the intensity of $\phi$ decreases further than that of $\delta_{\text {ring } \mathrm{C}=\mathrm{C}}$. This phenomenon implies there is reaction occur with the ring and methylene groups under the influence of steam. Since the adsorbed species orientates parallel with the surface, the reaction with steam can be more enhanced (more influence of the support) in comparison with the vertically adsorbed species on HT supports. Consequently, the amounts of species remained on HT can be higher due to combination result of adsorption and steam reforming step. It is in agreement with the TPO result where more coke was found on used HT support compared with IM support.

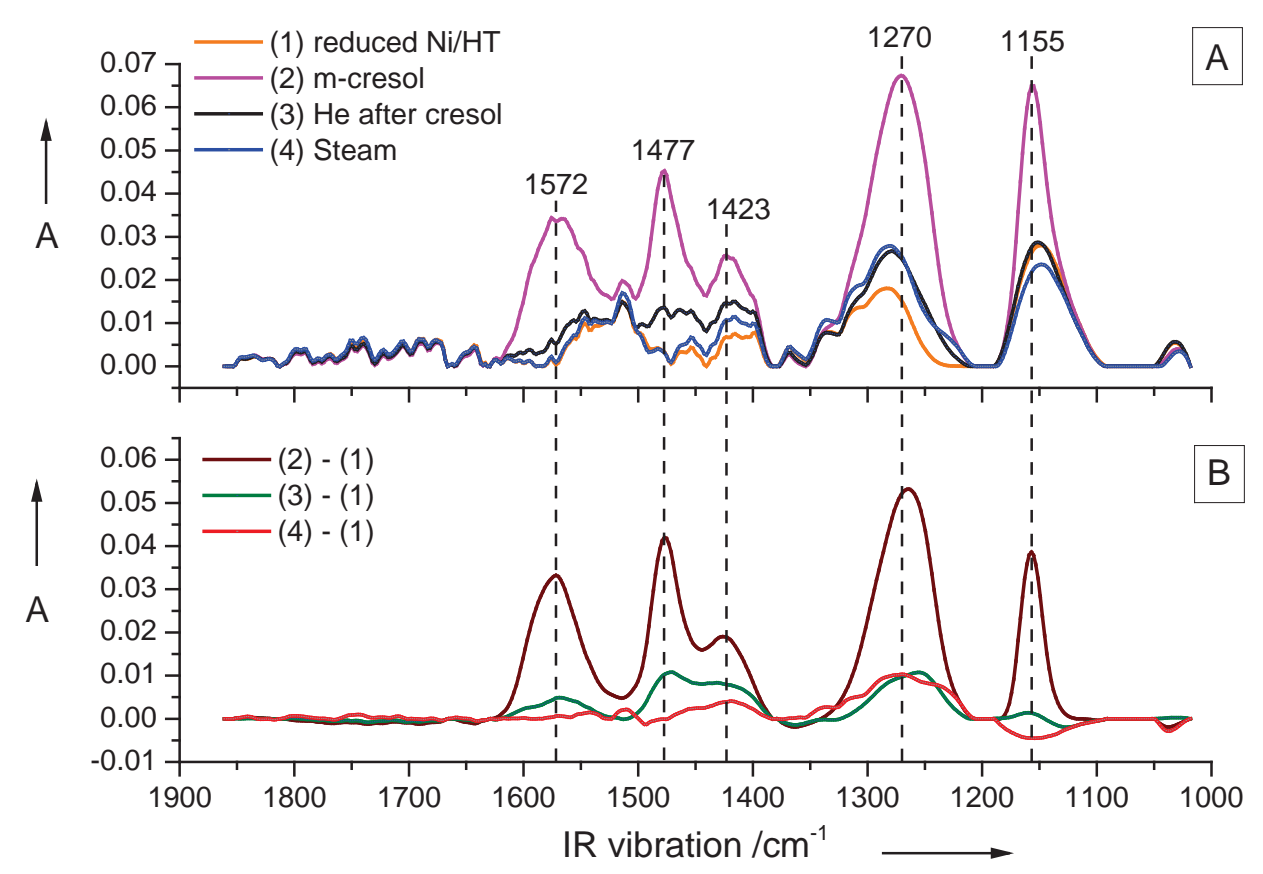

Figure 11. IR spectra recorded during titration typed steam reforming of $\mathrm{m}$-cresol on $\mathrm{Ni} / \mathrm{HT}$ at $450{ }^{\circ} \mathrm{C}$. A- baseline corrected spectra, B-different spectra compared with reduced one

Since Ni/HT shows lowest amount of coke and works better than Ni/IM, we only used $\mathrm{Ni} / \mathrm{HT}$ for the IR investigation with supported Ni catalyst. In comparison to the bare HT 
support, IR spectra for the Ni/HT (the orange line in Figure 5.11) does not show clear peaks for $\mathrm{C}-\mathrm{O}$ stretching $\left(v_{\mathrm{CO}}\right)$ vibration for carbonate or carboxylate in the region between 1600 and $1300 \mathrm{~cm}^{-1}$ [42]. Surprisingly, the introduction of $m$-cresol did not lead to any sorption bands even after an hour exposure as observed for HT support. This might indicate decomposition of $m$-cresol to IR inactive species probably. To probe this further, the partial pressure of $m$-cresol in the vapour feed mixture was increased from $13 \mathrm{~Pa}$ to $28 \mathrm{~Pa}$ for the adsorption of $m$-cresol step on $\mathrm{Ni} / \mathrm{HT}$ (corresponding to $m$-cresol concentration $128 \mathrm{ppm}$ and $276 \mathrm{ppm}$, respectively). However, even with the higher $m$-cresol concentration, it is hardly possible to observe any clear band for $\mathrm{C}-\mathrm{H}$ stretching vibration of both aromatic $\left(\sim 3050 \mathrm{~cm}^{-1}\right)$ or alkyl groups $\left(2850-2925 \mathrm{~cm}^{-1}\right)$ (not shown here). This can be due to the activation of C-H cleavage by Ni. FT-IR spectra in low wavenumber range recorded at the end of each step of the steam reforming on Ni/HT catalyst with higher m-cresol concentration is shown in Figure 5.11. The part A of Figure 5.11 exhibits the resulting spectra after baseline correction and the part B of the figure shows the corresponding spectra subtracted the spectrum of the catalyst just prior to the adsorption step when the catalyst was reduced in $\mathrm{H}_{2} / \mathrm{He}$ at $450{ }^{\circ} \mathrm{C}$ for an hour followed by an evacuation in He for 30 minutes. Surprisingly, the peak position in the range $1700-1000 \mathrm{~cm}^{-1}$ of adsorbed species on the catalyst after adsorption step is identical and similar to those adsorbed on the bare IM support.

In the baseline corrected spectra (Figure 5.11 - A) the peak at $1423 \mathrm{~cm}^{-1}$ may be thought of as red shifted $\mathrm{CH}_{2}$ deformation [42], but as we did not observe any $\mathrm{C}-\mathrm{H}$ stretching vibration. Thus, this is highly unlikely. In this region features corresponding to appearance of $\mathrm{COO}^{-}$ions [42], it is possible that the missing methyl group from $m$-cresol is oxidised by ceria to form a carbonate or carboxyl group.

The absence of the $\mathrm{OH}$ band between 1320 and $1400 \mathrm{~cm}^{-1}$, enhanced intensity of the band at 1477 and 1270 indicate the de-protonation in $\mathrm{OH}$ group of $m$-cresol. Thus it suggests that the adsorbed species anchor horizontally on the surface via both aromatic ring and phenolate groups. This is in agreement with literature on adsorption of phenol on Ni surface reported by Russell et al.[49]. The difference spectra of (3, evacuation in He after $m$-cresol sorption) minus (1, clean reduced surface) (Figure 5.11-B) shows the chemisorbed species on the catalyst. It can be seen that the ring $\mathrm{C}=\mathrm{C}$ still remain on the surface. However, under the steam/He flow, the bands for the skeletal ring vibrations (1572 and $1477 \mathrm{~cm}^{-1}$ ) are completely removed. No olefin intermediate (their band in the range $1650-1800 \mathrm{~cm}^{-1}$ ) is detected during all these experimental steps, suggesting that the $6 \mathrm{C}$ ring structure is disassociated at once on the Ni surface. 
Among these three supported $\mathrm{Ni}$ on $\mathrm{CeO}_{2}-\mathrm{ZrO}_{2}$ based catalysts, $\mathrm{Ni}$ on $\mathrm{Ce}-\mathrm{Zr}$ solid solution support synthesised via co-precipitation followed by hydrothermal treatment shows best activity and stability in steam reforming of $m$-cresol (Figure. 5.6 and 5.7). This catalyst has highest content of $\mathrm{Ce}^{3+}$ in the bulk phase as well as on the catalyst surface (XPS and TPR data) which is proportional to the oxygen vacancy within the catalyst system in reductive atmosphere or oxygen mobility in oxidative reaction condition. The mobile $\mathrm{O}$ in the $\mathrm{Ce}-\mathrm{Zr}$ solid solution can help with oxidation of adsorbed molecules. In situ FT-IR study on reforming of $m$-cresol shows that the sorption geometry/orientation of absorbed species are different in the two catalysts. In the case of $\mathrm{Ni} / \mathrm{HT}$, the methyl group may be oxidised through the interaction with active site on the support in the vicinity of $\mathrm{Ni}$ active particles; the whole aromatic ring inclines to the metal surface where de-protonation of $\mathrm{OH}$ group takes place. Then the aromatic ring $\mathrm{C}$ interacts with $\mathrm{Ni}$ and oxidised via steam reforming reactions. Therefore, with all the above mentioned remarks, they result in excellent performance of $\mathrm{Ni} / \mathrm{HT}$ catalyst. The catalysis of steam $m$-cresol reforming seems to involve manifold sites including $\mathrm{Ce}$ and $\mathrm{Ni}$ with multiple $\mathrm{Ni}$ sites which implies that larger Ni crystallites may be favoured and there should be an optimum as ceria is also involved.

\subsection{Conclusions}

For the steam reforming of $m$-cresol, Ni/HT catalyst shows the most promising among three $\mathrm{CeO}_{2}-\mathrm{ZrO}_{2}$ supported $\mathrm{Ni}$ catalysts. The hydrothermal treatment, beside improvement in the thermal resistance of the support, provides high concentration of $\mathrm{Ce}^{3+}$ on the surface as well as the bulk phase of the solid solution. This in turn improves the redox nature of the catalysts which contributes to its tremendous capability in steam reforming and coke oxidation via redox. The supported $\mathrm{Ni}$ attributes to major activity in breaking the $\mathrm{C}-\mathrm{C}$ and $\mathrm{C}$ $\mathrm{H}$ bonds of $m$-cresol. In situ FT-IR study reveals the horizontal adsorption of the aromatic rings on the Ni surface and interaction of methyl group with the support. This allows multiple cleavages to occur at the same time on the catalyst. Since manifold sites including Ni involve in the reforming of $m$-cresol, relatively large Ni crystallites (within optimum range) are more favoured.

\section{Bibliography}

[1] G.W. Huber, S. Iborra, A. Corma, Synthesis of transportation fuels from biomass: chemistry, catalysts, and engineering, Chemical reviews, 106 (2006) 4044-4098.

[2] D.M. Alonso, J.Q. Bond, J.A. Dumesic, Catalytic conversion of biomass to biofuels, Green Chemistry, 12 (2010) 1493-1513. 
[3] E. Kirtay, Recent advances in production of hydrogen from biomass, Energy Conversion and Management, 52 (2011) 1778-1789.

[4] R.M. Navarro, M.C. Sanchez-Sanchez, M.C. Alvarez-Galvan, F. del Valle, J.L.G. Fierro, Hydrogen production from renewable sources: biomass and photocatalytic opportunities, Energy \& Environmental Science, 2 (2009) 35-54.

[5] R.M. Navarro, M.A. Pena, J.L. Fierro, Hydrogen production reactions from carbon feedstocks: fossil fuels and biomass, Chemical reviews, 107 (2007) 3952-3991.

[6] D. Dayton, A review of the literature on catalytic biomass tar destruction, in: Milestone Completion Report, National Renewable Energy Laboratory, 2002.

[7] M.M. Yung, W.S. Jablonski, K.A. Magrini-Bair, Review of Catalytic Conditioning of Biomass-Derived Syngas, Energy \& Fuels, 23 (2009) 1874-1887.

[8] C. Wu, R.H. Liu, Carbon deposition behavior in steam reforming of bio-oil model compound for hydrogen production, International Journal of Hydrogen Energy, 35 (2010) 7386-7398.

[9] C. Wu, R. Liu, Hydrogen Production from Steam Reforming ofm-Cresol, a Model Compound Derived from Bio-oil: Green Process Evaluation Based on Liquid Condensate Recycling, Energy \& Fuels, 24 (2010) 5139-5147.

[10] A. Ishihara, E.W. Qian, I.N. Finahari, I.P. Sutrisna, T. Kabe, Addition effect of ruthenium on nickel steam reforming catalysts, Fuel, 84 (2005) 1462-1468.

[11] M. Marquevich, S. Czernik, E. Chornet, D. Montané, Hydrogen from biomass: Steam reforming of model compounds of fast-pyrolysis oil, Energy and Fuels, 13 (1999) 1160-1166.

[12] J. Han, H. Kim, The reduction and control technology of tar during biomass gasification/pyrolysis: An overview, Renewable and Sustainable Energy Reviews, 12 (2008) 397-416.

[13] T. Kimura, T. Miyazawa, J. Nishikawa, S. Kado, K. Okumura, T. Miyao, S. Naito, K. Kunimori, K. Tomishige, Development of Ni catalysts for tar removal by steam gasification of biomass, Appl Catal B-Environ, 68 (2006) 160-170.

[14] R. Di Monte, J. Kašpar, Nanostructured CeO2-ZrO2 mixed oxides, Journal of Materials Chemistry, 15 (2005) 633.

[15] P. Fornasiero, R. Dimonte, G.R. Rao, J. Kaspar, S. Meriani, A. Trovarelli, M. Graziani, Rh-Loaded CeO2-ZrO2 Solid-Solutions as Highly Efficient Oxygen Exchangers: Dependence of the Reduction Behavior and the Oxygen Storage Capacity on the Structural-Properties, Journal of Catalysis, 151 (1995) 168-177.

[16] G. Colón, M. Pijolat, F. Valdivieso, H. Vidal, J. Kašpar, E. Finocchio, M. Daturi, C. Binet, J.C. Lavalley, R.T. Baker, S. Bernal, Surface and structural characterization of CexZr1- 
xO2 CEZIRENCAT mixed oxides as potential three-way catalyst promoters, Journal of the Chemical Society, Faraday Transactions, 94 (1998) 3717-3726.

[17] G. Vlaic, R. Di Monte, P. Fornasiero, E. Fonda, J. Kašpar, M. Graziani, Redox propertylocal structure relationships in the Rh-loaded $\mathrm{CeO} 2-\mathrm{ZrO} 2$ mixed oxides, Journal of Catalysis, 182 (1999) 378-389.

[18] B. Matas Güell, I.V. Babich, L. Lefferts, K. Seshan, Steam reforming of phenol over Nibased catalysts - A comparative study, Applied Catalysis B: Environmental, 106 (2011) 280286.

[19] D.P. Biddiscombe, J.F. Martin, Vapour Pressures of Phenol and the Cresols, Transactions of the Faraday Society, 54 (1958) 1316-1322.

[20] Y.-Q. Song, H.-M. Liu, D.-H. He, Effects of Hydrothermal Conditions of $\mathrm{ZrO} 2$ on Catalyst Properties and Catalytic Performances of $\mathrm{Ni} / \mathrm{ZrO} 2$ in the Partial Oxidation of Methane, Energy \& Fuels, 24 (2010) 2817-2824.

[21] B.K. Kim, H.O. Hamaguchi, Mode assignments of the Raman spectrum of monoclinic zirconia by isotopic exchange technique, Phys Status Solidi B, 203 (1997) 557-563.

[22] E. Anastassakis, B. Papanicolaou, I.M. Asher, Lattice-Dynamics and Light-Scattering in Hafnia and Zirconia, Journal of Physics and Chemistry of Solids, 36 (1975) 667-676.

[23] T. Hirata, E. Asari, M. Kitajima, Infrared and Raman Spectroscopic Studies of ZrO2 Polymorphs Doped with Y2O3 or CeO2, Journal of Solid State Chemistry, 110 (1994) 201207.

[24] T. Hirata, Raman-active modes and the tetragonal-monoclinic phase transition in $\mathrm{ZrO} 2$ doped with 12mol\% CeO2, Journal of Physics and Chemistry of Solids 56 (1995) 951-957.

[25] D.J. Kim, J.W. Jang, H.L. Lee, Effect of tetravalent dopants on Raman spectra of tetragonal zirconia, J Am Ceram Soc, 80 (1997) 1453-1461.

[26] P. Biswas, D. Kunzru, Steam reforming of ethanol for production of hydrogen over $\mathrm{Ni} / \mathrm{CeO} 2-\mathrm{ZrO} 2$ catalyst: Effect of support and metal loading, International Journal of Hydrogen Energy, 32 (2007) 969-980.

[27] R. Hu, C. Yan, X. Zheng, H. Liu, Z.-y. Zhou, Carbon deposition on Ni/ZrO2-CeO2 catalyst during steam reforming of acetic acid, International Journal of Hydrogen Energy, 38 (2013) 6033-6038.

[28] R. Si, Y.-W. Zhang, S.-J. Li, B.-X. Lin, C.-H. Yan, Urea-Based Hydrothermally Derived Homogeneous Nanostructured Ce1-xZrxO2( $\mathrm{x}=0-0.8)$ Solid Solutions: A Strong Correlation between Oxygen Storage Capacity and Lattice Strain, The Journal of Physical Chemistry B, 108 (2004) 12481-12488.

[29] C. Diagne, H. Idriss, A. Kiennemann, Hydrogen production by ethanol reforming over $\mathrm{Rh} / \mathrm{CeO} 2-\mathrm{ZrO} 2$ catalysts, Catalysis Communications, 3 (2002) 565-571. 
[30] J. Fan, X. Wu, R. Ran, D. Weng, Influence of the oxidative/reductive treatments on the activity of Pt/Ce0.67Zr0.33O2 catalyst, Applied Surface Science, 245 (2005) 162-171.

[31] A. Laachir, V. Perrichon, A. Badri, J. Lamotte, E. Catherine, J.C. Lavalley, J. El Fallah, L. Hilaire, F. Le Normand, E. Quéméré, G.N. Sauvion, O. Touret, Reduction of $\mathrm{CeO} 2$ by hydrogen. Magnetic susceptibility and Fourier-transform infrared, ultraviolet and X-ray photoelectron spectroscopy measurements, Journal of the Chemical Society, Faraday Transactions, 87 (1991) 1601.

[32] A. Pfau, K.D. Schierbaum, The Electronic-Structure of Stoichiometric and Reduced Ceo2 Surfaces - an Xps, Ups and Hreels Study, Surface Science, 321 (1994) 71-80.

[33] S. Watanabe, X.L. Ma, C.S. Song, Characterization of Structural and Surface Properties of Nanocrystalline TiO2-CeO2 Mixed Oxides by XRD, XPS, TPR, and TPD, Journal of Physical Chemistry C, 113 (2009) 14249-14257.

[34] H. Vidal, J. Kašpar, M. Pijolat, G. Colon, S. Bernal, A. Cordón, V. Perrichon, F. Fally, Redox behavior of $\mathrm{CeO} 2-\mathrm{ZrO} 2$ mixed oxides, Applied Catalysis B: Environmental, 30 (2001) $75-85$.

[35] H. Vidal, J. Kašpar, M. Pijolat, G. Colon, S. Bernal, A. Cordón, V. Perrichon, F. Fally, Redox behavior of $\mathrm{CeO} 2-\mathrm{ZrO} 2$ mixed oxides I. Influence of redox treatments on high surface area catalysts, Applied Catalysis B: Environmental, 27 (2000) 49-63.

[36] J. Nishikawa, K. Nakamura, M. Asadullah, T. Miyazawa, K. Kunimori, K. Tomishige, Catalytic performance of $\mathrm{Ni} / \mathrm{CeO} 2 / \mathrm{A} 12 \mathrm{O} 3$ modified with noble metals in steam gasification of biomass, Catalysis Today, 131 (2008) 146-155.

[37] N. Hickey, P. Fornasiero, J. Kašpar, J.M. Gatica, S. Bernal, Effects of the nature of the reducing agent on the transient redox behavior of $\mathrm{NM} / \mathrm{Ce} 0.68 \mathrm{Zr} 0.32 \mathrm{O} 2(\mathrm{NM}=\mathrm{Pt}, \mathrm{Pd}$, and Rh), Journal of Catalysis, 200 (2001) 181-193.

[38] S. Salasc, V. Perrichon, M. Primet, M. Chevrier, N. Mouaddib-Moral, Oxygen Titration of Spill-Over Hydrogen in Ceria and Ceria-Alumina Supported Platinum-Rhodium Catalysts: Application to the Determination of the Ceria Surface in Contact with Metal, Journal of Catalysis, 189 (2000) 401-409.

[39] X.J. Li, J. Hayashi, C.Z. Li, FT-Raman spectroscopic study of the evolution of char structure during the pyrolysis of a Victorian brown coal, Fuel, 85 (2006) 1700-1707.

[40] A.C. Ferrari, J. Robertson, Interpretation of Raman spectra of disordered and amorphous carbon, Phys Rev B, 61 (2000) 14095-14107.

[41] J. Schwan, S. Ulrich, V. Batori, H. Ehrhardt, S.R.P. Silva, Raman spectroscopy on amorphous carbon films, Journal of Applied Physics, 80 (1996) 440-447.

[42] N.B. Colthup, L.H. Daly, S.E. Wiberley, Introduction to infrared and Raman spectroscopy, Academic Press, United State of America, 1990. 
[43] S. Benfer, E. Knozinger, Structure, morphology and surface properties of nanostructured ZrO2 particles, Journal of Materials Chemistry, 9 (1999) 1203-1209.

[44] G. Cerrato, S. Bordiga, S. Barbera, C. Morterra, Surface characterization of monoclinic $\mathrm{ZrO} 2$ I. Morphology, FTIR spectral features, and computer modelling, Applied Surface Science, 115 (1997) 53-65.

[45] J. Kondo, H. Abe, Y. Sakata, K.-i. Maruya, K. Domen, T. Onishi, Infrared studies of adsorbed species of $\mathrm{H} 2, \mathrm{CO}$ and $\mathrm{CO} 2$ over ZrO2, Journal of the Chemical Society, Faraday Transactions 1: Physical Chemistry in Condensed Phases, 84 (1988) 511-519.

[46] C. Binet, M. Daturi, J.C. Lavalley, IR study of polycrystalline ceria properties in oxidised and reduced states, Catalysis Today, 50 (1999) 207-225.

[47] H. Miyata, T. Ohno, F. Hatayama, FTIR studies of the interaction of aromatic hydrocarbons with vanadium oxide layered on $\mathrm{ZrO} 2$ and $\mathrm{TiO} 2$, Journal of the Chemical Society, Faraday Transactions, 91 (1995) 3505-3510.

[48] L. Palmisano, M. Schiavello, A. Sclafani, G. Martra, E. Borello, S. Coluccia, Photocatalytic Oxidation of Phenol on Tio2 Powders - a Fourier-Transform Infrared Study, Appl Catal B-Environ, 3 (1994) 117-132.

[49] J.N. Russell, S.S. Sarvis, R.E. Morris, Adsorption and Thermal-Decomposition of Phenol on Ni(110), Surface Science, 338 (1995) 189-203.

\section{Appendix 5}

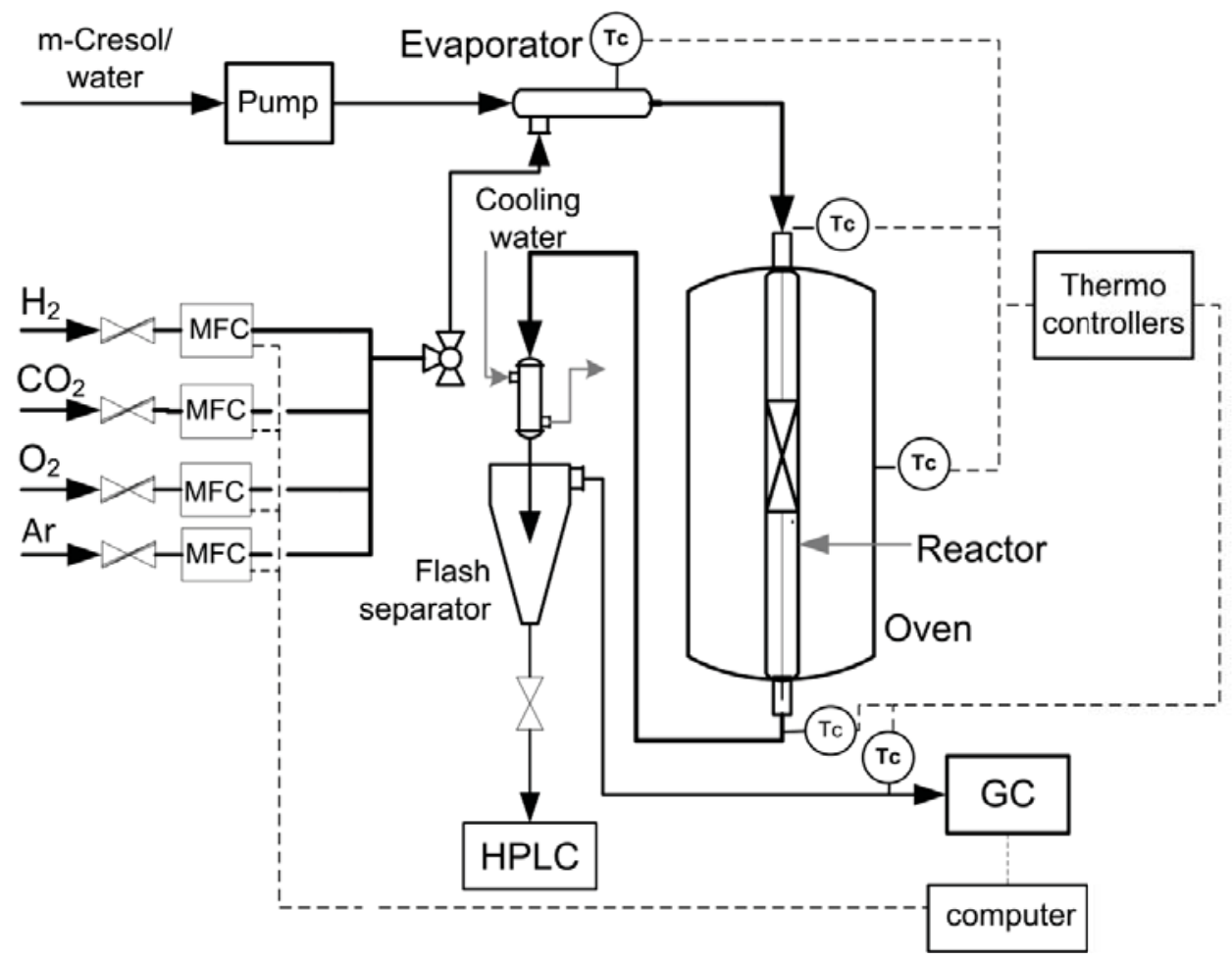

Figure A.5.1. Schematic flowsheet of the setup for steam reforming of m-cresol 
The conversion of m-cresol during the steam reforming with presence of supported $\mathrm{Ni}$ catalysts is calculated based on 2 main cumulative reactions below:

$$
\begin{aligned}
& \mathrm{C}_{7} \mathrm{H}_{8} \mathrm{O}+13 \mathrm{H}_{2} \mathrm{O} \rightarrow 7 \mathrm{CO}_{2}+17 \mathrm{H}_{2}(\mathrm{Eq} 1) \\
& \mathrm{C}_{7} \mathrm{H}_{8} \mathrm{O}+6 \mathrm{H}_{2} \mathrm{O} \rightarrow 7 \mathrm{CO}+10 \mathrm{H}_{2}(\mathrm{Eq} 2)
\end{aligned}
$$

Denote:

$\mathrm{a}[\mathrm{g} / \mathrm{min}]$ : amounts of $\mathrm{m}$-cresol is converted via $\mathrm{Eq} 1$ $\mathrm{b}[\mathrm{g} / \mathrm{min}]$ : amounts of $\mathrm{m}$-cresol is converted via Eq 2

$\mathrm{C}_{0}[\mathrm{~g} / \mathrm{ml}]$ : concentration of the $\mathrm{m}$-cresol solution delivered by the pump to the evaporator $\mathrm{C}[\mathrm{g} / \mathrm{ml}]$ : concentration of the liquid collected in the flash separator which is quantified by HPLC

d $[\mathrm{g} / \mathrm{ml}]$ : density of m-cresol, $1.03[\mathrm{~g} / \mathrm{ml}]$

$\mathrm{F}[\mathrm{ml} / \mathrm{min}]$ : flowrate of $\mathrm{m}$-cresol solution delivered by the pump Call:

$$
\mathrm{n}=\frac{\text { mole of } \mathrm{CO}}{\text { mole of } \mathrm{CO}_{2}} \rightarrow \mathrm{n}=\frac{\mathrm{b}}{\mathrm{a}}
$$

The amount of $\mathrm{m}$-cresol is supplied into the reactor $[\mathrm{g} / \mathrm{min}]=\mathrm{C}_{0} \cdot \mathrm{F}$ The amount of unconverted $\mathrm{m}$-cresol $[\mathrm{g} / \mathrm{min}]$

$$
\mathrm{C}_{0} \cdot \mathrm{F}-(\mathrm{a}+\mathrm{b})=\mathrm{C}_{0} \cdot \mathrm{F}-\mathrm{a} \cdot(\mathrm{n}+1)
$$

The amount of water consumed in Eq 1 and Eq $2[\mathrm{~g} / \mathrm{min}]$ :

$$
\frac{13 \times 18}{108} \cdot a+\frac{6 \times 18}{108} \cdot b=\frac{13}{6} \cdot a+b=\left(\frac{13}{6}+n\right) \cdot a
$$

The total volume of liquid condensed after the reactor $[\mathrm{ml} / \mathrm{min}]$ :

$$
\mathrm{F}-\frac{\mathrm{a}+\mathrm{b}}{\mathrm{d}}-\left(\frac{13}{6}+\mathrm{n}\right) \cdot \frac{\mathrm{a}}{1}=\mathrm{F}-\frac{\mathrm{n}+1}{\mathrm{~d}} \cdot \mathrm{a}-\left(\frac{13}{6}+\mathrm{n}\right) \cdot \mathrm{a}
$$

From (1) and (2):

$$
\mathrm{C}_{0} \cdot \mathrm{F}-\mathrm{a} \cdot(\mathrm{n}+1)=\mathrm{C} \cdot\left[\mathrm{F}-\frac{\mathrm{n}+1}{\mathrm{~d}} \cdot \mathrm{a}-\left(\frac{13}{6}+\mathrm{n}\right) \cdot \mathrm{a}\right]
$$

Solving equation (3)

$$
\rightarrow a=\frac{6 \cdot d \cdot F\left(C_{0}-C\right)}{6 \cdot n \cdot(d-d C-C)+6 d-6 C-13 d C}
$$

Conversion of m-cresol:

$$
\mathrm{X}=\frac{\mathrm{a}+\mathrm{b}}{\mathrm{F} \cdot \mathrm{C}_{0}}=\frac{\mathrm{a} \cdot(\mathrm{n}+1)}{\mathrm{F} \cdot \mathrm{C}_{0}}
$$

Replace a from (4) to (5), conversion is obtained:

$$
\begin{aligned}
X & =\frac{n+1}{F \cdot C_{0}} \cdot \frac{6 \cdot d \cdot F\left(C_{0}-C\right)}{6 \cdot n \cdot(d-d C-C)+6 d-6 C-13 d C} \\
\rightarrow X & =\frac{n+1}{C_{0}} \cdot \frac{6 \cdot d \cdot\left(C_{0}-C\right)}{6 \cdot n \cdot(d-d C-C)+6 d-6 C-13 d C}
\end{aligned}
$$

$\mathrm{C}$ and $\mathrm{C}_{0}$ is determined from HPLC. $\mathrm{n}$ is estimated from GC result. 


\title{
Steam reforming of acetic acid with nickel supported on ceria- zirconia
}

\begin{abstract}
Supported Ni on Ce-Zr mixed oxides was previously developed and showed promise for steam reforming of the oxygenate aromatic fraction (i.e. $m$-cresol) released during heating humin to gasification temperatures. Acetic acid amounts to the largest aliphatic fraction of the volatiles. It is also well known for causing deactivation to Ni based catalysts during steam reforming of oxygenates. Catalytic reforming of acetic acid using supported $\mathrm{Ni}$ on $\mathrm{Ce}-\mathrm{Zr}$ mixed oxide prepared via the hydrothermal route is reported in this chapter. The catalyst shows high activity and good stability. Furthermore, activity improvement was achieved with multiple redox cycles as relevant to recycling the catalysts. Characterisation of the fresh and used catalyst by various techniques (e.g., LEIS, Raman spectroscopy, TPO/TPR) revealed modification of metal-oxygen bond on the support thus increase of oxygen mobility of the catalyst.
\end{abstract}




\subsection{Introduction}

In chapter 3, we suggested a catalytic gasification scheme of humin for sustainable $\mathrm{H}_{2}$ production [1]. Gasification of humin with steam is possible using sodium based catalysts. The catalyst (i.e. $\mathrm{Na}_{2} \mathrm{CO}_{3}$ ) is active and stable under steam reforming at $750{ }^{\circ} \mathrm{C}$. Humin residues become graphitic, amorphous char at the gasification temperatures. During preheating step to gasification temperature, large amounts of organic volatiles which contain acetic acid, phenols, furans etc. are released from humin [1, 2]. The total volatiles including permanent gases such as $\mathrm{CO}_{2}, \mathrm{CO}$ account for $c a$. 25 per cent on carbon basis of humin. In order to use the whole carbon source from humin for making hydrogen/syngas, reduce waste, and also improve the purity of hydrogen stream it is essential to convert these organic volatiles during steam reforming. In chapter $5, \mathrm{Ce}-\mathrm{Zr}$ based supported $\mathrm{Ni}$ catalysts were developed for the steam reforming of $m$-cresol, one of the major aromatic components of the volatiles. The catalyst with supported $\mathrm{Ni}$ on $\mathrm{CeO}_{2}-\mathrm{ZrO}_{2}$ prepared via co-precipitation followed by hydrothermal treatment (catalyst named Ni/HT) showed the most promise [3]. This catalyst had high activity and selectivity to hydrogen, kept stable performance during thirty hours' time on stream. This catalyst also showed lowest amount of coke deposits. In addition to substituted phenols such as $m$-cresol, the volatiles also contain aliphatic oxygenates in which acetic acid is the major component $[1,2]$ (see chapter 2 and 3 ). With a view to probe the performance of the developed catalyst $(\mathrm{Ni} / \mathrm{HT})$ to be able to convert the whole of the volatiles, catalytic steam reforming of acetic acid was undertaken.

Nickel based catalysts is the most widely used in petroleum industry for steam reforming of naphtha and methane. Therefore, they are of interest for application in steam reforming of bio-oil/tar including acetic acid. Basagiannis and Verykios reported that $\mathrm{Ni}$ supported $\mathrm{Al}_{2} \mathrm{O}_{3}$ catalysts showed highest value of TOF compared with catalysts containing supported noble metals (e.g., Rh, Ru, Pt, Pd) [4]. In the same literature, the authors also noted that the carrier support had a strong influence on the apparent activation energies for the steam reforming reactions since these values altered most with the variation of support, yet with change in the type of active metal. Acidic supports such as $\mathrm{Al}_{2} \mathrm{O}_{3}$ favours cracking and condensation reactions, thus causing the deposition of coke and deactivation of catalyst as consequence $[4,5]$. Addition of basic oxides (e.g., $\mathrm{MgO}, \mathrm{CeO}_{2}, \mathrm{La}_{2} \mathrm{O}_{3}$ ) to alumina support enhanced the coking resistance thus improving the catalytic activity, stability $[4,6]$. Other support materials such as $\mathrm{ZrO}_{2}, \mathrm{La}_{2} \mathrm{O}_{3}, \mathrm{CeO}_{2}$ have also been used. However, despite the lower acidity in comparison with $\mathrm{Al}_{2} \mathrm{O}_{3}$, severe coke formation was also observed [7-10] with $\mathrm{ZrO}_{2}$. Masta Güell et al. reported that the Pt catalyst using $\mathrm{CeO}_{2}$ support is more stable than that using $\mathrm{ZrO}_{2}$. This improvement was explained by the facile redox properties of $\mathrm{CeO}_{2}$ which 
can help the oxidation of coke deposits with water, preventing severe accumulation of coke thus slowing down the deactivation rate. In addition, the oxygen storage capacity, one of the important variables for the redox properties of $\mathrm{CeO}_{2}$ can be further increased by doping other elements such as $\mathrm{Zr}, \mathrm{Tb}, \mathrm{Gd}[11,12]$. Catalytic activity, redox properties of ceria is enhanced when it is incorporated with Zr. Research about ceria-zirconia supports for hydrogen production from alkanes and oxygenates were recently reviewed by Nahar and Dupont which shows the strong influence of preparation methods on texture, OSC and redox properties of the catalyst thus catalytic activity for steam reforming [12]. Furthermore, reductive/oxidative pre-treatment can also modify the redox properties of ceria-zirconia [13-15]. The steam reforming condition also contains reductive/oxidative elements. Thus, it raises the question about how this condition will impact the catalytic properties.

In this chapter, we studied the performance of $\mathrm{Ni}$ supported on ceria-zirconia prepared via hydrothermal route since it showed best activity and stability in steam reforming of $\mathrm{m}$ cresol. In addition, influence of reductive/oxidative treatments (either during the steam reforming or recycling of the catalysts) on its catalytic properties was also investigated.

\subsection{Experimental}

\subsubsection{Catalyst preparation}

All the chemicals used in this research are analytical grades purchased from Sigma Aldrich. The chemicals were used without any further purification.

Ceria-zirconia oxide support was prepared via co-precipitation of $\mathrm{Ce}$ and $\mathrm{Zr}$ precursors $\left(\mathrm{Ce}\left(\mathrm{NO}_{3}\right)_{3} \cdot 6 \mathrm{H}_{2} \mathrm{O}\right.$ and $\left.\mathrm{ZrO}\left(\mathrm{NO}_{3}\right)_{2} \cdot \mathrm{xH}_{2} \mathrm{O}\right)$ with ammonia followed by hydrothermal treatment in $40 \mathrm{wt} . \% \mathrm{KOH}$ for 24 hours. The support was calcined in air at $800{ }^{\circ} \mathrm{C}$ for 6 hours prior to deposition of $\mathrm{Ni}$ via homogeneous deposition precipitation of $\mathrm{Ni}\left(\mathrm{NO}_{3}\right)_{2} \cdot 6 \mathrm{H}_{2} \mathrm{O}$ with urea. The supported Ni catalyst was then calcined in air at $500{ }^{\circ} \mathrm{C}$, reduced subsequently in $10 \mathrm{vol} . \%$ $\mathrm{H}_{2} / \mathrm{N}_{2}$ at $650{ }^{\circ} \mathrm{C}$ for 1 hour. Hereby the catalyst is denoted as Ni/HT catalyst. In all thermal treatment steps, a corresponding gas flow of $50 \mathrm{ml}^{\mathrm{min}}{ }^{-1}$ and ramping temperature rate of 5 ${ }^{\circ} \mathrm{C}$ was used. Details of catalyst synthesis were described in chapter 5.

\subsubsection{Catalytic performance}

The catalytic experiments were carried out in an $\alpha$-alumina fix bed reactor (internal diameter of $4 \mathrm{~mm}$ ) at atmospheric pressure. The catalyst powder was pressed, crushed and sieved to sizes between $0.3-0.6 \mathrm{~mm}$. The catalytic bed was held in place by two quartz wool plugs. Typically, the catalyst was reduced in situ with $50 \mathrm{ml}$ flow of $10 \mathrm{vol} \% \mathrm{H}_{2} /$ Argon at 
$650{ }^{\circ} \mathrm{C}$ for 1 hour, then purged under the flow of Ar for 30 minutes before the furnace was set to gasification temperatures $\left(600-700{ }^{\circ} \mathrm{C}\right)$. Aqueous acetic acid solutions were delivered to an evaporator by a syringe pump (ISCO Model 500 D). The evaporator and the connected tubing to the reactor were heated at $145^{\circ} \mathrm{C}$. The vapour was carried to the reactor by Ar flow. At the end of the reforming step, the reactor was cooled down in argon flow to room temperature prior to the regeneration step. Parameters of flow-rate of feed streams, amount of catalyst and vapour concentration is summarised in Table 6.1. In all cases the weight hourly space velocity solely based on acetic acid (WHSV) are similar and equals to $25.2 \mathrm{~h}^{-1}$.

\begin{tabular}{|c|c|c|c|c|c|c|}
\hline \multirow{2}{*}{$\begin{array}{c}{[\mathrm{AcOH}]_{\text {feed }}} \\
(\mathrm{g} / \mathrm{L})\end{array}$} & \multirow{2}{*}{$\begin{array}{l}\mathrm{S} / \mathrm{C} \\
\text { ratio }\end{array}$} & \multirow{2}{*}{$\begin{array}{c}F_{\text {liquid }} \\
\left(\mathrm{ml} \cdot \mathrm{min}^{-1}\right)\end{array}$} & \multirow{2}{*}{$\begin{array}{c}\text { Catalyst } \\
(\mathrm{mg})\end{array}$} & \multicolumn{3}{|c|}{ Gas flowrate, $\mathrm{ml} \cdot \mathrm{min}^{-1}[\mathrm{a}]$} \\
\hline & & & & $\mathrm{Ar}$ & $\mathrm{AcOH}$ & Steam \\
\hline 104.7 & 14 & 0.1 & 25 & 25 & 4.2 & 120 \\
\hline 252.8 & 5 & 0.083 & 50 & 45 & 8.4 & 84 \\
\hline
\end{tabular}

In the case of using recycled catalyst, each steam reforming run was separated by regeneration step in which the catalyst (from the previous cycle, in the same reactor) was oxidised in 20 vol.\% air/Ar (total flow-rate $30 \mathrm{ml} . \mathrm{min}^{-1}$ ) at $650{ }^{\circ} \mathrm{C}$ for 90 minutes then cooled down to room temperature before used in the next experiment according to the procedure mentioned above. A heating/cooling rate of $10{ }^{\circ} \mathrm{C} \cdot \mathrm{min}^{-1}$ was used in all the ramping temperature steps.

Ar was also used as internal standard gas for determination of total gas evolving during the steam reforming. Gas outlet stream from the reactor was cooled and separated using a flash condenser cooled by continuous water stream at $15^{\circ} \mathrm{C}$. Gas composition was analysed by an online Varian CP-3800 gas chromatograph. The liquid from the flash condenser was collected every 30 minute intervals for the first 2 hour TOS and then with the frequency of every $1-2$ hour. Composition of the condensed phase from the reactor was analysed using a Shimadzu HPLC system with a Animex HPX-87H column and a Refractive Index detector (RID-10D). Mobile phase of $\mathrm{H}_{2} \mathrm{SO}_{4}\left(0.005 \mathrm{M}, 0.6 \mathrm{ml} \cdot \mathrm{min}^{-1}\right)$ was used for the separation. Column oven was maintained at $35^{\circ} \mathrm{C}$. It took typically 25 minutes for an analysis.

Acetic acid conversion was calculated as the mole of acetic acid reacted divided by the mole of acetic acid fed to the reactor. Hydrogen yield was defined as hydrogen in the product stream compared with the maximum $\mathrm{H}_{2}$ that could be produced from reaction Eq 1). Methane and acetone yield was estimated from reactions (Eq 2) and (Eq 3), respectively : 
$\mathrm{CH}_{3} \mathrm{COOH}+2 \mathrm{H}_{2} \mathrm{O} \rightarrow 2 \mathrm{CO}_{2}+4 \mathrm{H}_{2}(\mathrm{Eq} 1)$

$\mathrm{CH}_{3} \mathrm{COOH} \rightarrow 2 \mathrm{H}_{2}+2 \mathrm{CO}(\mathrm{Eq} 2)$

$2 \mathrm{CH}_{3} \mathrm{COOH} \rightarrow \mathrm{CH}_{3} \mathrm{COCH}_{3}+\mathrm{H}_{2} \mathrm{O}+\mathrm{CO}_{2}(\mathrm{Eq} 3)$

Therefore the yield and selectivity gas products were estimated on carbon basis (except for $\mathrm{H}_{2}$ ) and from the equations, below:

Conversion $(\%)=100 \% \times \frac{n_{A c O H c}}{n_{A c O H f}}=100 \% \times \frac{n_{A c O H f}-n_{A c O H u}}{n_{A c O H f}}$

Yield of $\mathrm{H}_{2}(\%)=100 \% \times \frac{\text { moles of hydrogen produced }}{4 \times \text { moles of acetic acid feed }}$

Yield of $\mathrm{CO} / \mathrm{CO}_{2} / \mathrm{CH}_{4}(\%)=100 \% \times \frac{\text { moles of } \mathrm{CO} / \mathrm{CO}_{2} / \mathrm{CH}_{4} \text { produced }}{2 \times \text { moles of acetic acid feed }}$

Yield of acetone $(\%)=100 \% \times \frac{3 \times \text { moles of acetone produced }}{2 \times \text { moles of acetic acid feed }}$

Selectivity to $\mathrm{CO} / \mathrm{CO}_{2} / \mathrm{CH}_{4}(\%)=100 \% \times \frac{\text { moles of } \mathrm{CO} / \mathrm{CO}_{2} / \mathrm{CH}_{4} \text { produced }}{2 \times \text { moles of acetic acid converted }}$

where $\mathrm{n}_{\mathrm{AcOHf}}, \mathrm{n}_{\mathrm{AcOHc}}$ and $\mathrm{n}_{\mathrm{AcOHu}}$ are the moles of acetic acid that was fed to the reactor, converted and unconverted during reforming, respectively. The amounts of unconverted acetic acid was calculated from HPLC data with the assumption that negligible amount of acetic acid vapour in the gas stream to GC. Thus, condensed liquid volume is theoretically calculated based on the feed concentration and water consumed in Eq 1. Carbon balance of $97 \pm 3 \%$ was achieved in all experiments if not specifically mentioned.

\subsubsection{Characterisation of catalysts}

Main characteristics of the fresh catalyst is summarised in Table 6.2. For temperature programmed reduction (TPR) or oxidation (TPO), the catalysts $(10-50$ $\mathrm{mg}$, with grain size of $0.3-0.6 \mathrm{~mm}$ ) were held between two quartz plugs in a cylinder, $\alpha$-alumina reactor $(4 \mathrm{~mm}$

Table 6.2. Characteristics of $\mathrm{Ni} / \mathrm{HT}$ catalyst

\begin{tabular}{|c|c|}
\hline Specific area $\left(\mathrm{m}^{2} \mathrm{~g}^{-1}\right)$ & 42.2 \\
\hline Pore volume $\left(\mathrm{cm}^{3} \mathrm{~g}^{-1}\right)$ & 0.29 \\
\hline $\mathrm{Ce} / \mathrm{Zr}$ atomic ratio & $0.2^{\dagger}\left(0.23^{\dagger}\right)$ \\
\hline Ni loading (wt.\%) & 3.2 \\
\hline $\begin{array}{l}\text { Surface } \mathrm{Ni} / \mathrm{Ce} / \mathrm{Zr} \text { (atomic } \\
\text { ratio) }{ }^{\ddagger}\end{array}$ & $14.7 / 69.2 / 16.1$ \\
\hline $\mathrm{Ce}^{3+} /$ Total Ce $(\%)$ & $43^{\ddagger}\left(80^{*}\right)$ \\
\hline \multicolumn{2}{|l|}{${ }^{\dagger}$ : based on XRF } \\
\hline *: based on XPS result & \\
\hline
\end{tabular}


internal diameter), pre-treated in inert gas (Ar or He for TPR or TPO, respectively) at $150{ }^{\circ} \mathrm{C}$ for 30 minutes then cooled down to room temperature prior to the analysis. 5 vol. $\% \mathrm{H}_{2} / \mathrm{Ar}(25$ ml.min $\left.{ }^{-1}\right)$ or 1 vol. $\% \mathrm{O}_{2} / \mathrm{He}\left(75 \mathrm{ml} \cdot \mathrm{min}^{-1}\right)$ was used as reactive for these analyses, respectively. $\mathrm{H}_{2}$ consumption was followed by a standard thermal conductivity detector which was calibrated by conducting similar TPR procedure with known amounts of NiO (purity $99.999 \%$, purchased from Sigma Aldrich). In TPO analysis of coke deposits on catalysts, $\sim 6$ vol. $\%$ of gas stream from the reactor, containing $\mathrm{CO}$ or $\mathrm{CO}_{2}$, was sent to an online methanizer (Model 110 Chassis, SRI Instruments Europe $\mathrm{GmbH}$ ) where $\mathrm{CO}$ and $\mathrm{CO}_{2}$ were converted to methane. The evolution of methane was monitored and quantified using a FID detector which was calibrated in the same TPO procedure using known amounts of $\mathrm{Al}_{2}\left(\mathrm{CO}_{3}\right)_{3}$ as carbon source. In TPR or TPO measurement, the furnace was heated to $700{ }^{\circ} \mathrm{C}$ at the rate of $5{ }^{\circ} \mathrm{C} \cdot \mathrm{min}^{-1}$ then kept at that end temperature for 30 minutes and subsequently cooled down to room temperature $\left(10^{\circ} \mathrm{C} \cdot \mathrm{min}^{-1}\right)$.

Raman measurements were performed in ambient condition using a visible Bruker Senterra Raman spectrometer (wavenumber $532 \mathrm{~cm}^{-1}$ ) equipped with a CCD detector. In each scan, samples were exposed to laser power of $5 \mathrm{~mW}$ for $1-2 \mathrm{~s}$. The Raman spectra were average of 50-100 scans with spectral resolution $3-5 \mathrm{~cm}^{-1}$.

Low-Energy Ion Scattering LEIS) was performed with commercially available equipment (ION-TOF $\operatorname{Qtac}^{100}$ from ION-TOF). A catalyst sample was pressed to a pellet, which was pre-treated with atomic oxygen in order to remove hydrocarbon contamination before introduction in the analysis chamber. Both He and Ne were used as primary ion source, with a dose density of typically $2 \times 10^{14}$ ion. $\mathrm{cm}^{-2}$ per spectrum.

\subsection{Results}

\subsubsection{Influence of temperature on catalyst performance}

Figure 6.1 shows the performance of $\mathrm{Ni} / \mathrm{HT}$ for steam reforming of acetic acid in the temperature range $600-700{ }^{\circ} \mathrm{C}$, including the conversion of acetic acid, yields and selectivities to various products. First, it can be easily seen that the conversion of acetic acid, and selectivity to different products depend strongly on the reforming temperatures. The catalyst shows very high conversion at the beginning ( $90-98 \%$, Fig 6.1-A). However, its activity experiences rapid initial deactivation which happens within the first $\sim 4$ hours TOS. The rate of initial deactivation is strongly dependant on the temperature. For example, at 600 ${ }^{\circ} \mathrm{C}$, the conversion dropped from $\sim 90 \%$ to $\sim 50 \%$ in 2 hours TOS, while at $700{ }^{\circ} \mathrm{C}$ the activity loss was only $6 \%$. The conversions dropped ca. $16 \%$ in the next 23 hours TOS at all three 
reforming temperatures. This slow gradual deactivation seems to be independent of the reforming temperature.
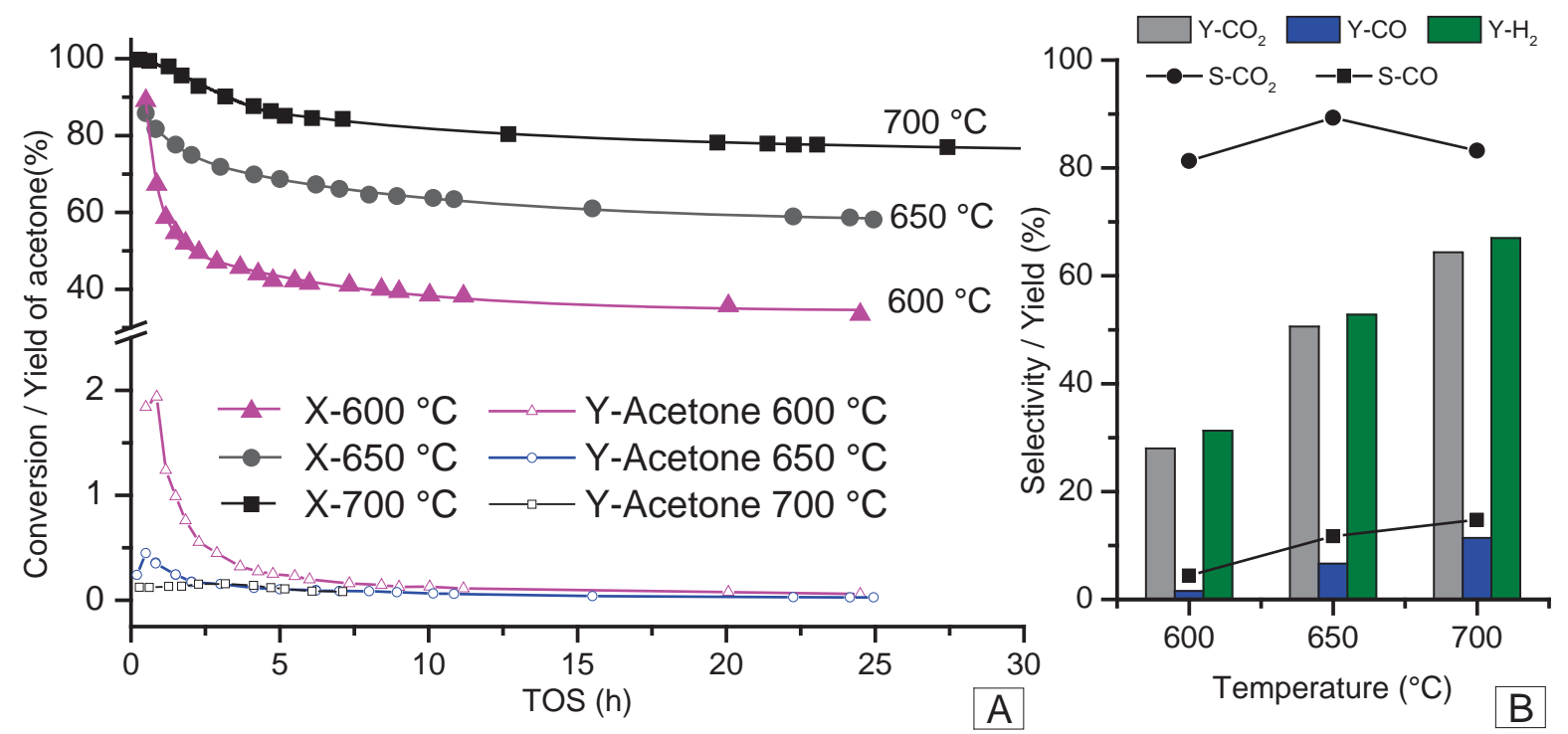

Figure 6.1. Influence of reforming temperature on performance of catalyst: A- conversion of $\mathrm{AcOH}$ and yield of acetone; B- Selectivity and yield of gaseous products at steady state

The identified products of steam reforming of acetic acid (Fig 6.1-B) included CO, $\mathrm{CO}_{2}, \mathrm{H}_{2}$, acetone and trace amounts of methane. It should be noted that no other hydrocarbons beside $\mathrm{CH}_{4}$ was detected throughout all experiments within our experimental conditions. The highest yield of acetone was obtained at $600{ }^{\circ} \mathrm{C}$ in the first $1 \mathrm{~h}$ TOS while at $700{ }^{\circ} \mathrm{C}$ this value was negligible (less than $0.16 \%$ ). Since acetone is intermediate product formed from acetic acid its presence in the product stream indicates that its formation rate is higher than its conversion rate in subsequent reactions, e.g., to syngas, hydrogen Yield of acetone declines after $4-6 \mathrm{~h}$ TOS when the conversion approaches steady state. This implies that the initial deactivation of catalyst is strongly connected with the formation of acetone. $\mathrm{CO}$ and $\mathrm{CO}_{2}$ are the main $\mathrm{C}$ containing products of steam reforming. When the catalyst reached steady state at $600{ }^{\circ} \mathrm{C}$, selectivity of $\mathrm{CO}_{2}$ and $\mathrm{CO}$ is around 80 and $5 \%$ on carbon basis, respectively. The carbon balance in this case is quite poor $(88 \pm 2 \%)$. This implies besides acetone and $\mathrm{CO}_{\mathrm{x}}$, there are large amount of unidentified products (e.g., coke precursors, coke). The highest selectivity towards $\mathrm{CO}_{2}(\sim 88 \%$ on $\mathrm{C}$ basis $)$ at steady state was achieved at reforming temperature of $650{ }^{\circ} \mathrm{C}$. The selectivity to $\mathrm{CO}_{2}$ at $700{ }^{\circ} \mathrm{C}$ was slightly lower than that $650{ }^{\circ} \mathrm{C}$ which is due to less favourable conditions for the exothermic water gas shift reaction. In both cases $\left(650 \& 700{ }^{\circ} \mathrm{C}\right)$, carbon balance of $97 \pm 3 \%$ was obtained. The yield of hydrogen is proportional to acetic acid conversion and the selectivity to $\mathrm{CO}_{\mathrm{x}}$. Due to the highest 
conversion and yield of $\mathrm{H}_{2}$, as well as the lowest yield of acetone, reforming temperature of $700{ }^{\circ} \mathrm{C}$ was selected for further investigations.

As mentioned in the previous section, the temperature has strong influence on deactivation rate (with regard to conversion - activity). In this section, impact of steam/carbon ratio on the deactivation rate is further investigated. Figure 6.2 shows the performance of $\mathrm{Ni} / \mathrm{HT}$ catalyst with a steam/carbon ratio of 5 . In the case of $\mathrm{S} / \mathrm{C} 14$ (Figure 6.1-A), the conversion dropped from $\sim 100$ to $\sim 76.7 \%$ after 30 hours TOS. Here in the case S/C 5 (Figure 6.2), the conversion of acetic acid dropped from $\sim 90$ to $63.6 \%$. This amounts to catalyst loss in activity of $\sim 23.3 \%$ and $27 \%$ with S/C - 14 and S/C - 5, respectively. Selectivity to $\mathrm{CO}(\sim 15 \%)$ in these two cases is similar while selectivity to $\mathrm{CO}_{2}$ in the case $\mathrm{S} / \mathrm{C} 14$ is higher. This must be due to the enhanced WGS reaction because of the higher partial pressure of steam. The same trend is indicated by the $\mathrm{K}_{\text {WGS }}$ calculated and shown in Figure 6.2. Quantification of coke deposited on the used catalysts shows that the coke content is similar (C 1.8 wt.\%) in both cases. In agreement with the degree of loss in activity (25\% vs. $27 \%$ ), it seems that the steam to carbon ratio in the range from 5 to 14 has only a very minor impact on the coke content.

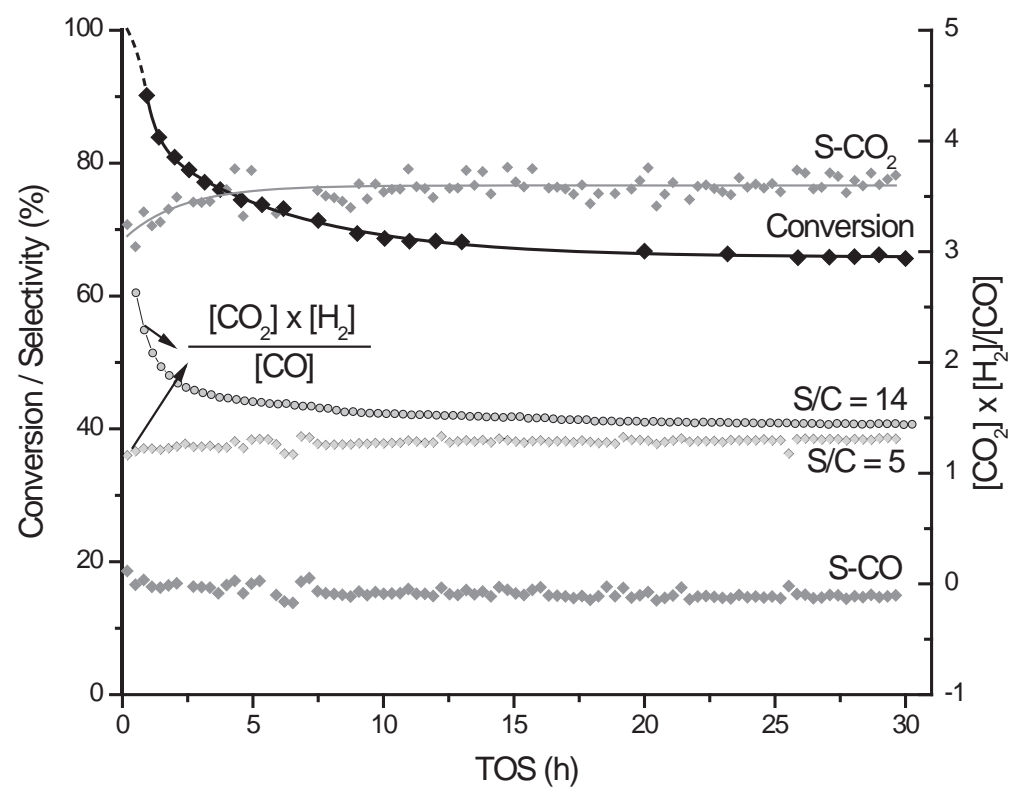

Figure 6.2. Steam reforming of $\mathrm{AcOH}$ in presence of $\mathrm{Ni} / \mathrm{HT}$ catalyst with steam to carbon ratio of $5, \mathrm{~T}=700{ }^{\circ} \mathrm{C}$, WHSV $=25.2 \mathrm{~h}^{-1}$

Figure 6.3 shows the conversion and yields of products from the reforming of $\mathrm{AcOH}$ on the bare $\mathrm{HT}$ support. $\mathrm{CO}_{2}, \mathrm{CO}, \mathrm{CH}_{4}, \mathrm{H}_{2}$ and acetone were detected as products here also. Initial conversion of $\mathrm{AcOH}$ was as high as $\sim 90 \%$ which rapidly decreased to $\sim 4 \%$ within 2 
hours' time on stream. Yields of identified products follow the same trend. No further changes in conversion and yields of products were observed after 2 hours. Thus the support is strongly deactivated and the low residual yields of products such as $\mathrm{CO}_{2}, \mathrm{CH}_{4}, \mathrm{H}_{2}, \mathrm{CO}$ was due to remaining activity of the catalyst/coke or reactions in gas phase. It is also seen that the production of acetone in this case only occurred within the first $2 \mathrm{~h}$ TOS, or during the active period of the support

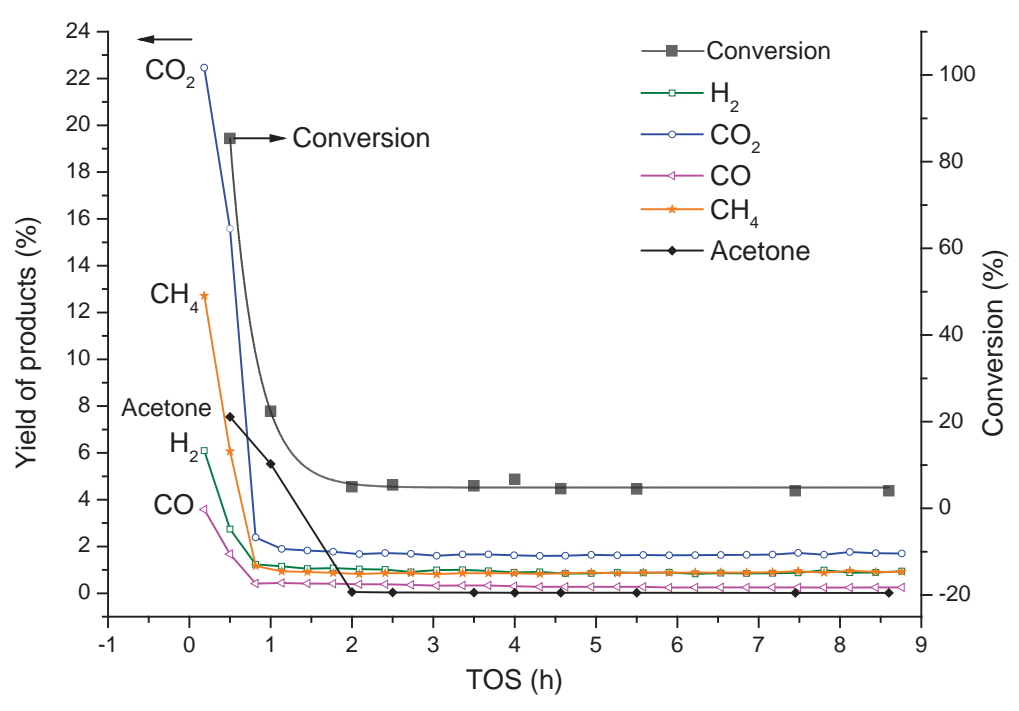

Figure 6.3. Reforming of acetic acid on bare HT support WHSV $=25.2 \mathrm{~h}^{-1} ; \mathrm{S} / \mathrm{C}=5$; at 700 ${ }^{\circ} \mathrm{C}$

\subsubsection{Influence of catalyst recycle}

Compared with the fresh catalyst, recycled one experienced the deactivation and regeneration by coke combustion followed by $\mathrm{H}_{2}$ reduction. These reaction, treatment activities can have influence on the performance of the recycled catalyst, which is displayed in Figure 6.4. It can be seen that when $\mathrm{S} / \mathrm{C}$ ratio of 14 is used, the conversion with recycled catalyst - Run 5 is higher than the conversion achieved with the fresh catalyst - Run 1 (Figure 6.4-A). The conversion of AcOH at steady state increased from $\sim 75 \%$ to $82 \%$. This increase of conversion is the direct cause for increase of $\mathrm{H}_{2}$ yield (Figure 6.4-A). The similar trend of higher conversion and yield of $\mathrm{H}_{2}$ is also observed in run 2 for the case of using S/C ratio 5/1 (See Appendix section). For product distribution, at steady state, the selectivity to $\mathrm{CO}_{2}$ decreased whereas selectivity to $\mathrm{CO}$ increases with the recycled catalysts (Figure 6.4-B). Interestingly, the yields of $\mathrm{CO}_{2}$ are similar in all these runs but yield of $\mathrm{CO}$ is increased clearly. This increase in yield of CO corresponds to the gain in conversion. Data result from various characterisation techniques shown in later section were employed to understand the evolution happened to the catalyst under sequential steam reforming of acetic acid. 


\subsubsection{Characterisation of catalysts}

Low-energy ion scattering spectroscopy (LEIS) was used to analyse the changes in surface composition of the catalyst. This surface sensitive analytical technique allows to get information of the very first layer of the catalyst surface. Figure 6.5 shows the LEIS spectra, obtained by scattering of $5 \mathrm{keV} \mathrm{Ne}$ ions, normalised to intensity of the Ce peak. It can easily be observed that the relative $\mathrm{Ce} / \mathrm{Zr}$ peak ratio of the supported $\mathrm{Ni}$ catalysts is higher than that of the bare support. The $\mathrm{Ce} / \mathrm{Zr}$ ratio of the support is expected to be similar to the bulk $\mathrm{Ce} / \mathrm{Zr}$ ratio of the catalyst even after $\mathrm{Ni}$ deposition. This value $(\mathrm{Ce} / \mathrm{Zr}=0.2)$ is derived from $\mathrm{XRF}$ result. For the surface composition of the fresh supported $\mathrm{Ni}$ catalyst, $\mathrm{Ce} / \mathrm{Zr}$ atomic ratios is 0.23 (obtained from XPS). Therefore, the increase of $\mathrm{Ce} / \mathrm{Zr}$ atomic ratio on the surface observed with LEIS is in agreement with previous results obtained from XPS and XRF. The higher cerium coverage on the surface can be due to two reasons: (i) migration of $\mathrm{Ce}$ to the surface during the reduction treatment [16], or (ii) $\mathrm{Zr}$ is covered by $\mathrm{Ni}$ - in the other words $\mathrm{Ni}$ precursors deposit preferably on $\mathrm{Zr}$ rather than Ce site during the homogenous deposition precipitation. The disappearance of hafnium (omnipresent impurity in zirconium precursors) on the supported catalyst is also caused by preference deposition of $\mathrm{Ni}$ precursor, albeit its presence on the
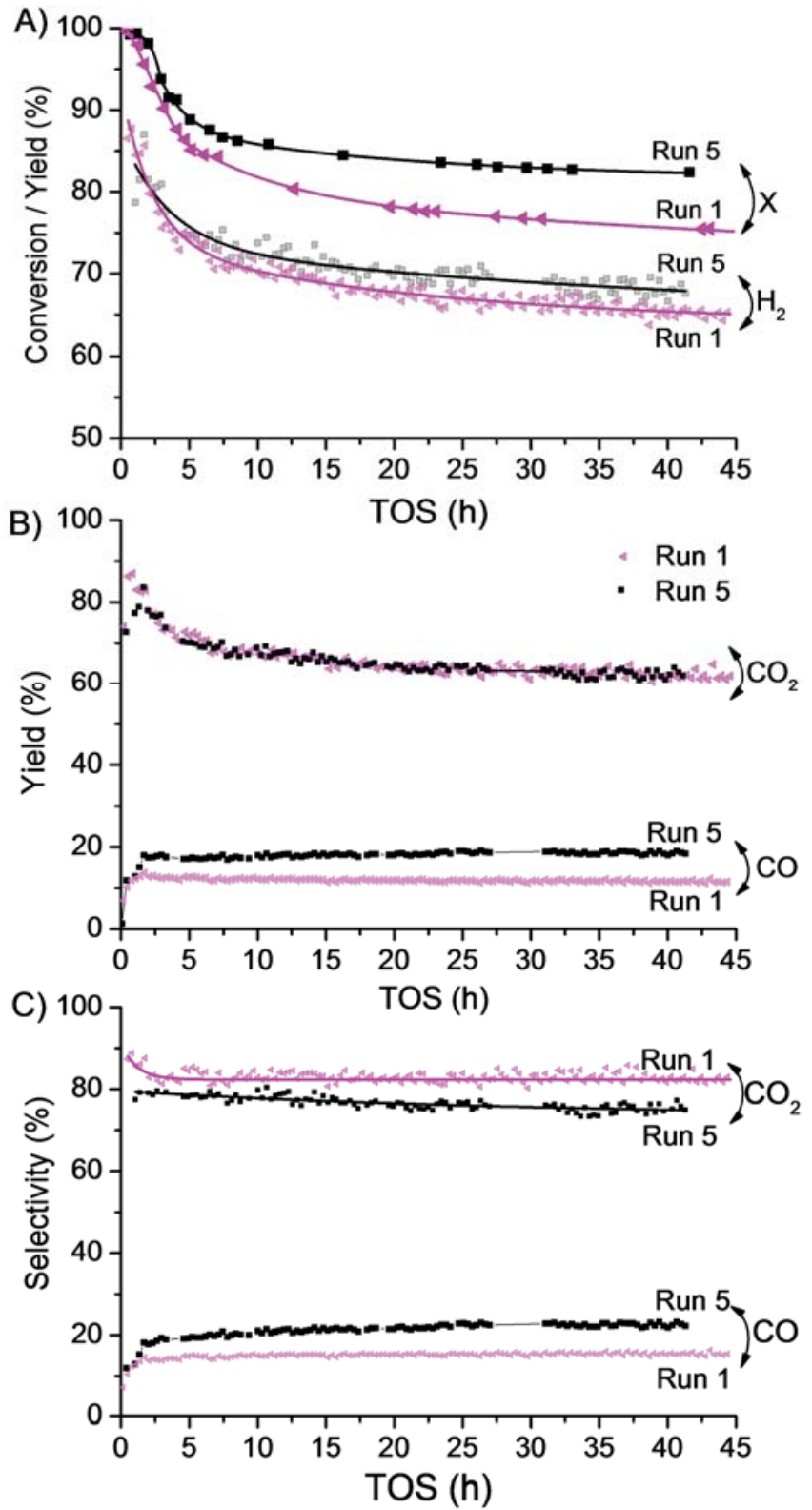
surface of the corresponding support. Figure 6.4. Influence of catalyst recycle on steam Therefore, the second reason for increase reformoing of AcOH: A- conersion/yield of $\mathrm{H}_{2}$, Bof $\mathrm{Ce} / \mathrm{Zr}$ ratio (in other word decrease of yield of $\mathrm{CO}_{\mathrm{x}}, \mathrm{C}$ - selectivity to $\mathrm{CO}_{\mathrm{x}}$. Condition: $\mathrm{T}=$ $\mathrm{Zr} / \mathrm{Ce}$ ) is more likely in this case. By $700^{\circ} \mathrm{C}, \mathrm{WHSV}_{\mathrm{AcOH}}=25.2 \mathrm{~h}^{-1}, \mathrm{~S} / \mathrm{C}=14 / 1$ 


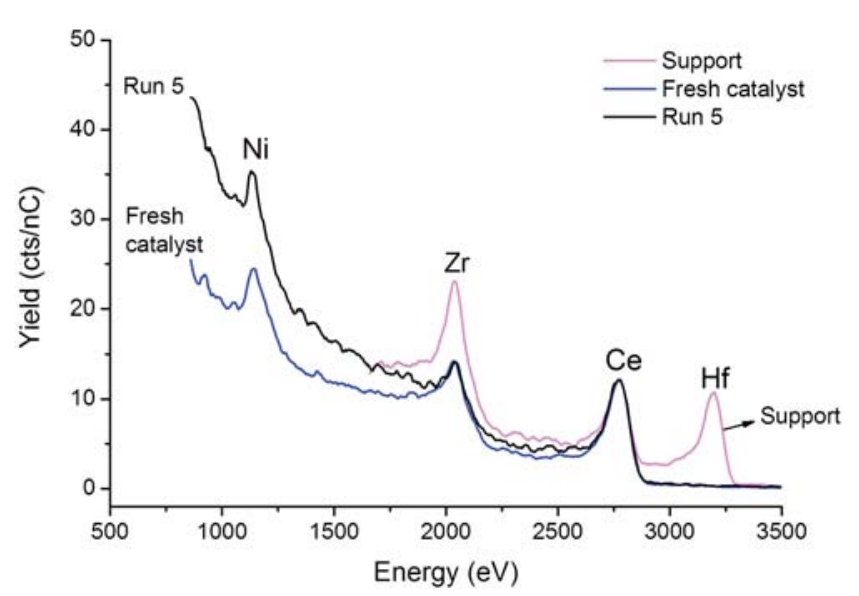

Figure 6.5. LEIS spectra of support, fresh and catalyst after run 5

comparing the relative ratios of peaks for $\mathrm{Ni}, \mathrm{Ce}$ and $\mathrm{Zr}$, respectively (Figure 6.5), there might be a very slight decrease of $\mathrm{Ni}$ and $\mathrm{Zr}$ compared with $\mathrm{Ce}$ between the fresh catalyst and the catalyst after 5 times of recycle. Therefore, break down of $\mathrm{Ni}$ particles, that increases the surface area of $\mathrm{Ni}$ nano-particles, thus varying the atomic ratios of $\mathrm{Ni}$ to other elements on the surface of the catalyst, is not expected. Additionally, it should be noted that the spectral baseline of the recycled catalyst increased sharply in the low energy range. This effect can be attributed to sputtering of light elements from the catalyst surface. LEIS measurements with He as primary ion showed that the 5 times recycled sample had a 1.2 times larger oxygen surface coverage compared to the fresh catalyst and a small contamination of silicon oxide which comes from the quartz wool used to keep the catalyst bed stationary inside the reactor $(7 \%$ of the Si surface coverage of a Si wafer exposed to $\mathrm{O}$ plasma). Time-of-flight measurements of $\mathrm{Ne}$ scattering confirm that the increased background of the recycled catalyst is due to sputtering of $\mathrm{O}$ an $\mathrm{d} \mathrm{Si}$ (not shown here).

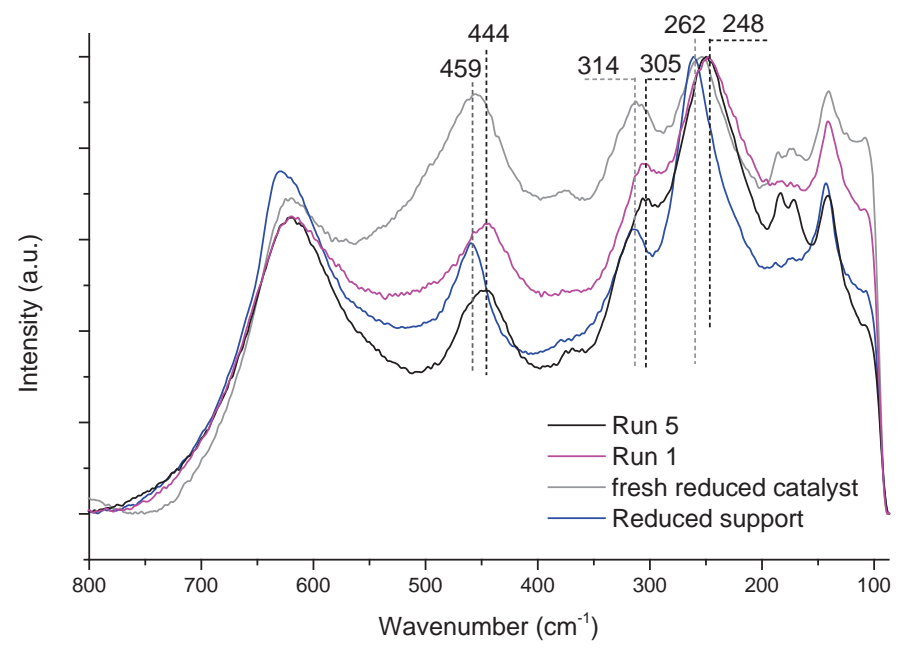

Figure 6.6. Raman spectra of fresh and used catalysts after steam reforming. Inset graph is Raman bands for coke. Raman spectra were recorded in ambient condition ( $21^{\circ} \mathrm{C}, 1$ bar) with laser wavelength $532 \mathrm{~nm}$ and normalised to the peak at $\sim 250 \mathrm{~cm}^{-1}$ 
Figure 6.6 shows the Raman spectra of the catalysts which are scaled to the band around $250 \mathrm{~cm}^{-1}$. Major spectral features of the Raman spectra from $100 \mathrm{~cm}^{-1}$ to $750 \mathrm{~cm}^{-1}$ of the catalysts are typical for tetragonal phase for $\mathrm{CeO}_{2}-\mathrm{ZrO}_{2}$ oxides: $\sim 625 \mathrm{~cm}^{-1}$ (A $\mathrm{A}_{1 \mathrm{~g}}$ mode), $444-459 \mathrm{~cm}^{-1}$ (E mode), $314 \mathrm{~cm}^{-1}$ ( $B_{1 \mathrm{~g}}$ mode), $248-262 \mathrm{~cm}^{-1}$ (E $\mathrm{E}_{\mathrm{g}}$ mode) and $140-144 \mathrm{~cm}^{-}$ ${ }^{1}$ ( $\mathrm{B}_{1 \mathrm{~g}}$ mode) [17]. The Raman vibration at $593 \mathrm{~cm}^{-1}$ for tetragonal phase which is reported by Hirata et al.[17] is not seen clearly in all spectra. This is probably due to overlap with other bands. Besides, vibrational modes for monoclinic phase were also found, peaks at $376 \mathrm{~cm}^{-1}$ ( $\mathrm{B}_{\mathrm{g}}$ mode), $306 \mathrm{~cm}^{-1}, 171 \mathrm{~cm}^{-1}, 183 \mathrm{~cm}^{-1}$ ( $\mathrm{A}_{\mathrm{g}}$ mode). The presence of these bands is also in agreement with the Raman spectrum of the un-reduced support.

It can be seen from Figure 6.6 that the $\mathrm{E}_{\mathrm{g}}$ vibration mode (peaks at $\sim 460 \mathrm{~cm}^{-1}$ and 260 $\mathrm{cm}^{-1}$ ) of the catalysts after exposing to steam reforming condition (Run 1 and Run 5) shifts to lower wavenumber $\left(459 \mathrm{~cm}^{-1}\right.$ to $444 \mathrm{~cm}^{-1}$ and $262 \mathrm{~cm}^{-1}$ to $248 \mathrm{~cm}^{-}$ $\left.{ }^{1}\right)$ compared to reduced fresh catalyst or reduced fresh support. The $\mathrm{E}_{\mathrm{g}}$ mode at $444-460 \mathrm{~cm}^{-1}$ is assigned to the asymmetric $\mathrm{Zr}-\mathrm{O}-$ $\mathrm{Zr}$ or Ce-O-Ce stretching while the $E_{\mathrm{g}}$ mode at $260 \mathrm{~cm}^{-1}$ corresponds to $\mathrm{Zr}-\mathrm{O}$ stretching [18] or $\mathrm{Ce}^{3+}$ [19]. These red shifts imply cation-oxygen stretching becoming weakened as the result of lower energy of vibrations. This indicates certain modification of cation-oxygen bond (i.e., lengthening of bond) [18]. Thus, oxygen can become more labile, causing increase in oxygen mobility. The red shift of $E_{g}$ mode (from $459 \mathrm{~cm}^{-1}$ to $444 \mathrm{~cm}^{-1}$ ) is much larger than those of recycled ceria - zirconia mixed oxides (the

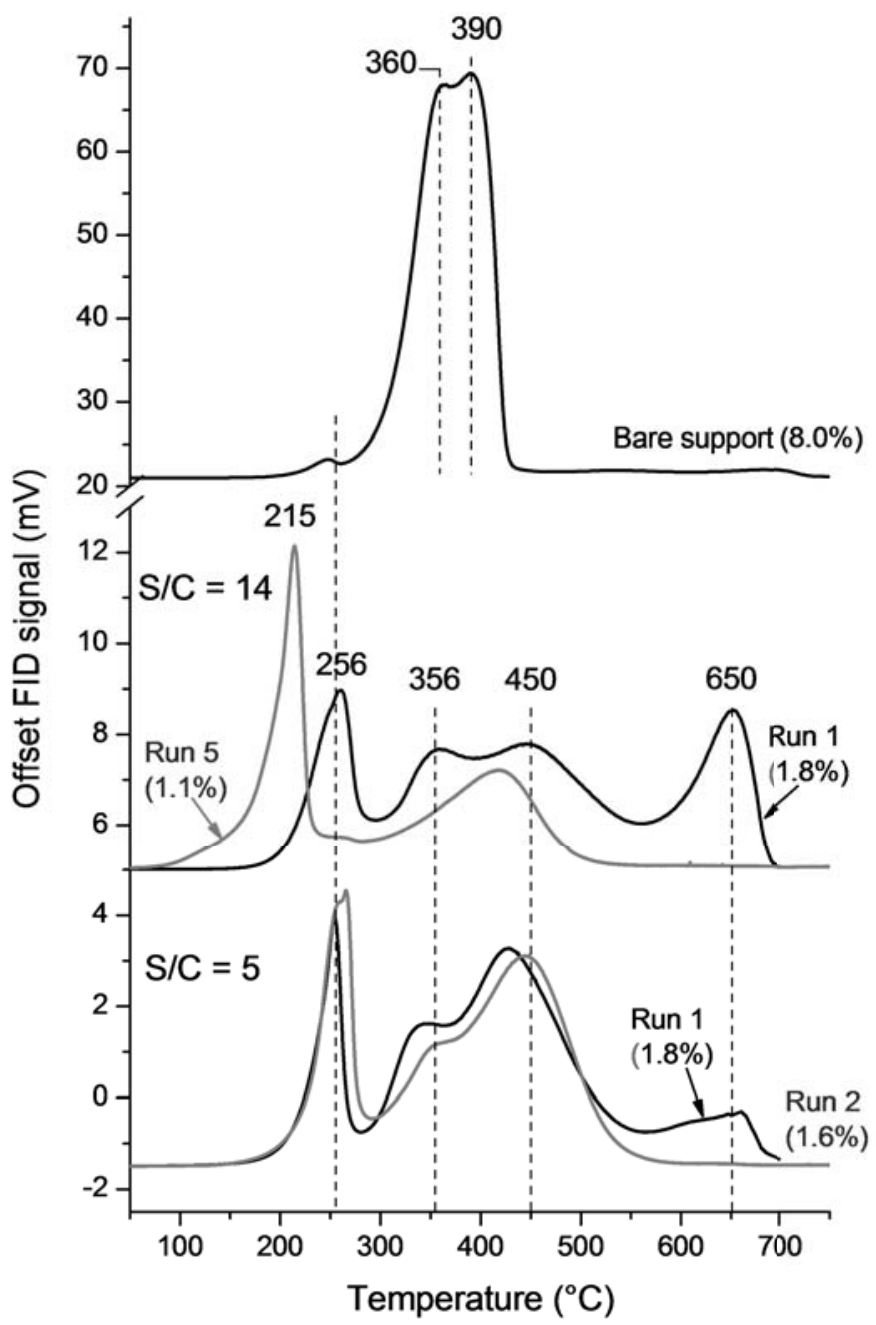

Figure 6.7. TPO profile of catalysts normalised to 1 mg of catalysts. Numbers in bracket indicate the carbon content deposited on the catalysts 
samples were exposed to oxidative/reductive sequence) reported in literature $[11,14,17$, 20-24]. We suggest that the redox process occurring in the steam reforming of acetic acid has stronger influence on modification of the cation oxygen bonds (between $\mathrm{Ce}$ or $\mathrm{Zr}$ with $\mathrm{O})$ than conventional redox treatment. This aspect will be elucidated later by TPR analysis.

Figure 6.7 shows the TPO profiles of catalysts. Coke contents (on carbon basis) were calculated based on the area of TPO peaks. The oxidation profile of the coke deposited on the bare support consists two significant oxidation peaks at $360^{\circ} \mathrm{C}$ and 390 ${ }^{\circ} \mathrm{C}$ and a low-intensity peak at $250{ }^{\circ} \mathrm{C}$. The coke deposited on the catalysts after the first reforming cycle with both steam/carbon ratios (5 and 14) were very similar both in carbon contents and oxidation profile. These consist 4 oxidation temperatures $256{ }^{\circ} \mathrm{C}, \quad 356^{\circ} \mathrm{C}$,

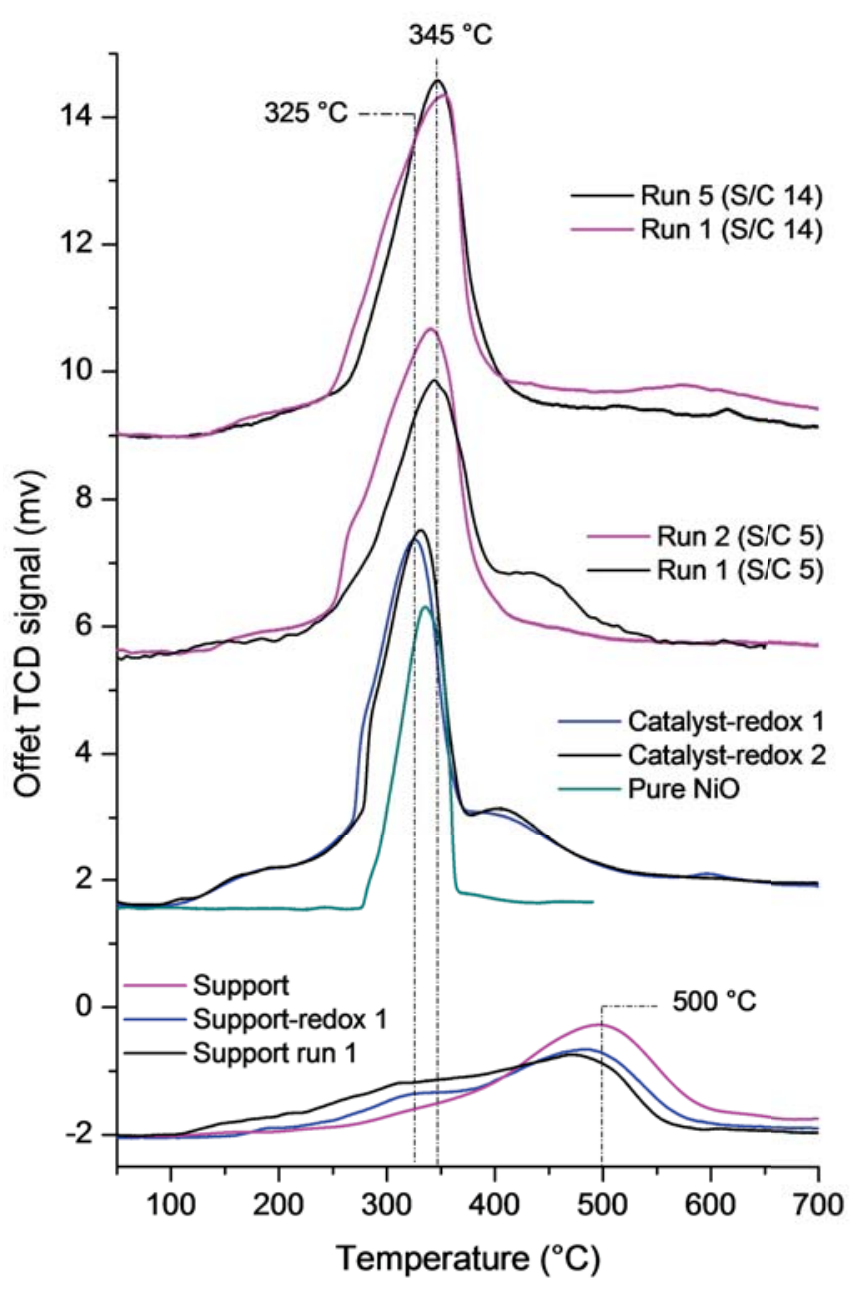

Figure 6.8. TPR profile of catalyst. The intensity of TPR signal of catalysts were scaled to $50 \mathrm{mg}$ and TPR signal of $\mathrm{NiO}$ was normalised to the same amount of $\mathrm{NiO}$ in the catalyst. Support-redox 1 , catalyst redox 1 and 2 are fresh support and catalyst which experienced sequence of re-oxidation followed by TPR 1 and 2 times, respectively. Used support, run 1, 2, 5 are those obtained after TPO analysis of correspondent catalysts $450^{\circ} \mathrm{C}$ and $\sim 650{ }^{\circ} \mathrm{C}$. The peaks at $210-250{ }^{\circ} \mathrm{C}$ can be assigned to strongly adsorbed intermediates of acetic acid on the support. This low oxidation temperature of coke deposits in acetic acid reforming was reported by Vagia et al. [25] and Lemonidu et al. [26]. However, supported $\mathrm{Rh}$ on $\mathrm{CeO}_{2}-\mathrm{ZrO}_{2}$ or $\mathrm{CeO}_{2}-\mathrm{ZrO}_{2}$ modified with 3 wt.\% La catalysts were used in their cases. The peak above at $650{ }^{\circ} \mathrm{C}$ on the supported $\mathrm{Ni}$ catalyst after the first cycle can be due to the intermediate species which formed in presence of Ni particles. Surprisingly, the coke on recycled catalysts (run 5 
for S/C 14 and run 2 for S/C 5) does not contain any coke component that is oxidised at high temperature - at $650{ }^{\circ} \mathrm{C}$ (i.e., all the peaks were below $450{ }^{\circ} \mathrm{C}$ ). Especially for catalyst after run 5 , the oxidation temperatures of the coke shifted to much lower temperature $\left(30-40{ }^{\circ} \mathrm{C}\right.$ lower).

The dependency of redox properties of $\mathrm{CeO}_{2}-\mathrm{ZrO}_{2}$ materials on the reductive/oxidative treatments which is referred as thermal ageing is well-known in literature [13-15, 20, 27, 28]. Reducibility of ceria based oxides can be enhanced by exposing the samples to sequence of deep reductive treatment followed by mild oxidative treatment [14]. Therefore, similar improvements can be expected with the recycled catalysts used in this study since recycling of catalyst includes oxidation of coke followed by a reduction pre-treatment for the next reforming cycle. Thus, investigating the reducibility of the catalyst can help to explain their catalytic performance in the steam reforming. It should be remarked that most of the research on the influence of thermal aging focus on the enriched Ce solid oxide solutions (i.e. Ce molar content above $50 \%$ ).

TPR profiles of the supports and catalysts are illustrated in Figure 6.8. Since, in the case of used catalysts, the TPR analysis was carried out following the TPO experiment to remove the coke deposits (i.e., samples were oxidised in 1 vol.\% $\mathrm{O}_{2} / \mathrm{He}$ to typically $700{ }^{\circ} \mathrm{C}$ then cooled down in He to room temperature), the fresh catalyst was also pre-treated in the same condition (i.e. re-oxidised to $700{ }^{\circ} \mathrm{C}$ ) prior to each TPR experiment to mimic the thermal treatment history. The TPR profile of fresh support has an asymmetric shape centred at $\sim 500{ }^{\circ} \mathrm{C}$. The support that experienced a cycle of redox (reduction to $700{ }^{\circ} \mathrm{C}$ followed by re-oxidation to $700{ }^{\circ} \mathrm{C}$ ) is labelled as support-redox 1 on Figure 6.8. TPR profile of the support-redox consists of two peaks at $\sim 320^{\circ} \mathrm{C}$ and $483{ }^{\circ} \mathrm{C}$ in which the onset of reduction occurs at lower temperature compared with the fresh support $\left(150{ }^{\circ} \mathrm{C} v\right.$ s. $\left.200{ }^{\circ} \mathrm{C}\right)$. The TPR profile of the support which was used for the steam reforming of $\mathrm{AcOH}$ is quite similar to the support-redox 1 except that the reduction initiates at $c a .100{ }^{\circ} \mathrm{C}$ and larger part of ceria is reduced at lower temperature range (the range below $420{ }^{\circ} \mathrm{C}$ ). This phenomenon indicates the reduction of the treated support as well as the used support is facilitated, thus improving the reducibility. In the other words, the reductive/oxidative recycle modifies the metal ( $\mathrm{Zr}$ or $\mathrm{Ce}$ ) - oxygen bonds, making oxygen atoms more labile. This associates with the oxygen mobility in the lattice of the materials, leading to facile $\mathrm{Ce}^{4+} / \mathrm{Ce}^{3+}$ redox reaction. Therefore, the thermal aging treatment (viz. reduction/oxidation of support in $\mathrm{H}_{2}$ or $\mathrm{O}_{2}$ respectively) and the reductive/oxidative condition of steam reforming gives improvement to the oxygen mobility of the support. About $80 \%$ ceria $\left(\mathrm{Ce}^{4+}\right)$ is reduced to $\mathrm{Ce}^{3+}$ by the end of the TPR experiments for bare supports. This result is in coincidence with literature [14]. 
Secondly, for the supported $\mathrm{Ni}$ catalysts reduction is initiated at relatively lower temperature $\left(\sim 100{ }^{\circ} \mathrm{C}\right)$ and gradually increases until $\sim 270{ }^{\circ} \mathrm{C}$. Then the reduction sharply increases and shows an asymmetric peak at $325-345{ }^{\circ} \mathrm{C}$. This peak can be related to reduction of bulk $\mathrm{NiO}$ on the catalyst since pure $\mathrm{NiO}$ (purchased from Sigma Aldrich, thus large particle size is expected) also shows a strong reduction peak in this temperature range. Additionally, a broad reduction peak at $420-435{ }^{\circ} \mathrm{C}$ is found in some cases. Combining with the TPR profile of the support, the broad, asymmetric reduction area beneath the sharp peak at $325-345{ }^{\circ} \mathrm{C}$ which peaks at $420-435{ }^{\circ} \mathrm{C}$ and spans from $\sim 100$ to the end of the temperature program $\left(700{ }^{\circ} \mathrm{C}\right)$ is mainly attributed to the reduction of the $\mathrm{Ce}-\mathrm{Zr}$ support which is promoted by the presence of Ni. In the case of thermally aged catalysts (catalyst redox 1 and 2) their reduction profiles are quite similar. This indicates that the repeated redox treatment in $\mathrm{O}_{2}$ and $\mathrm{H}_{2}$ does not cause further significant changes in reducibility of the catalyst after the first reduction-oxidation cycle. However, the recycled catalysts which had been exposed to the steam reforming conditions show some differences compared with the thermally aged catalysts. It can be seen that the highest reduction peak at $\sim 345^{\circ} \mathrm{C}$ becomes broader and shift to higher temperature $\left(345 \mathrm{vs} .325^{\circ} \mathrm{C}\right)$. Remarkably, the peaks for support reduction become less distinct and fuse with the main peak, making the overlapped total peak shift to $345{ }^{\circ} \mathrm{C}$ in the case of catalyst with several recycle time (the Run 2 and Run 5 catalyst with S/C ratio of 5 and 14, respectively). This demonstrates the more facile reduction of the recycled catalysts. The total $\mathrm{H}_{2}$ consumption of all supported $\mathrm{Ni}$ catalysts (fresh and recycled catalysts) just vary within the machine error. The $\mathrm{Ce}^{3+} /$ total $\mathrm{Ce}$ ratios are estimated as $80 \pm 6 \%$ with assumption that all Ni is completely reduced.

\subsection{Discussions}

Reaction pathways which occur in catalytic steam reforming of acetic acid is illustrated in Scheme 6.1 taking in to account the works reported by Lemonidou et al.,[26] Takanabe et al. [7, 29], Pestman et al.[30], and Barteau's group [31, 32]. In the case of steam reforming in presence of only oxide supports (e.g. $\mathrm{ZrO}_{2}, \mathrm{CeO}_{2}, \mathrm{Al}_{2} \mathrm{O}_{3}$ ) conversion of acetic acid through the formation of acetone is favourable. Further condensation of acetone via reaction (11) (14) is believed to be the main cause for coke formation on the support, blocking the active sites and leading to the deactivation of catalyst. Both acidic or basic sites are known to activate the formation of acetone from acetic acid. However, basic supports such as $\mathrm{CeO}_{2}$, $\mathrm{La}_{2} \mathrm{O}_{3}$ or $\mathrm{CeO}_{2} / \mathrm{MnO}_{2}$ solid solutions are more active than acidic supports for acetone formation [4]. In this study, the bare support itself shows high activity early TOS for conversion of acetic acid to acetone (compared with the non-catalytic thermal steam reforming) when the catalyst is strongly deactivated (conversion $90 \%$ vs. $4 \%$ ). High yield of 
$\mathrm{CO}_{2}$ and $\mathrm{CH}_{4}$ in the beginning suggests that conversion of acetic acid follows reactions (1), (2) and (9). Yields of $\mathrm{CH}_{4}$ and $\mathrm{H}_{2}$ decline faster than that of acetone indicating the limited number of actives sites on the support for forming ${ }^{*} \mathrm{CH}_{\mathrm{x}}$ and these sites are quickly blocked by coke formation probably via reaction (16). Active sites for acetone formation, reaction (9), last longer $(\sim 2 \mathrm{~h})$. The poor carbon balance achieved in the case of reforming on bare support implies the large amounts of $\mathrm{AcOH}$ or active carbon species (e.g., ${ }^{*} \mathrm{CH}_{3-\mathrm{x}}$, acetone) are further converted into unidentified products which includes coke deposits. That explained the high coke content in this case (C 8 wt.\% - Figure 6.8). The accumulation of coke on the support blocks the active sites on the catalysts and inhibits further conversion of $\mathrm{AcOH}$. At the end when all the active sites are blocked, the conversion of acetic acid is just thermal or due to activity of the coke.

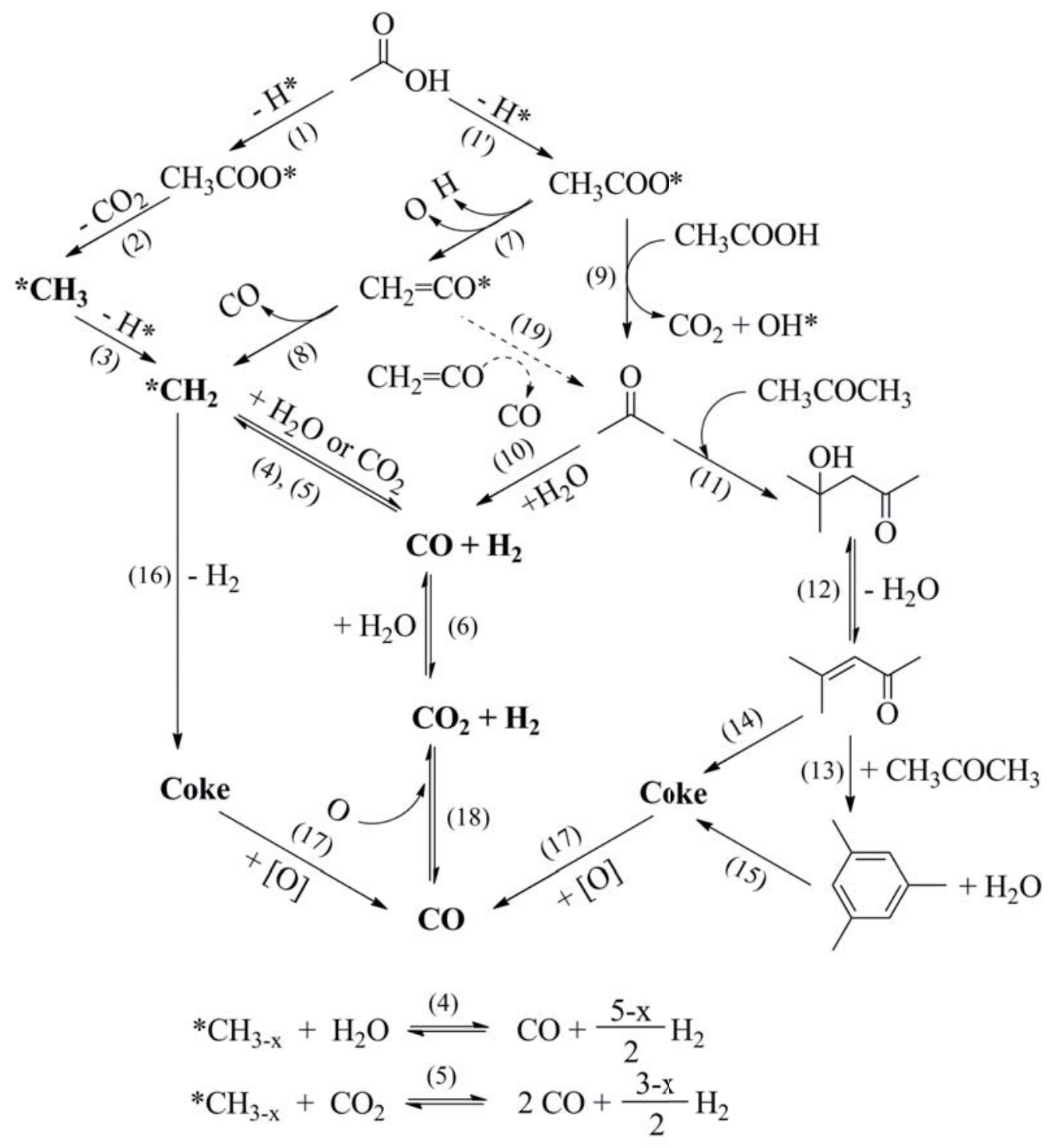

Scheme 6.1. Reaction pathways occurring in steam reforming of acetic acid 
In the case of $\mathrm{Ce}-\mathrm{ZrO}_{2}$ supported $\mathrm{Ni}$ catalyst, the conversion of $\mathrm{AcOH}$ is maintained above $75 \%$ after $45 \mathrm{~h}$ TOS with stable selectivity to $\mathrm{CO}_{\mathrm{x}}$ (almost 100\%). Therefore, reforming capability of the catalyst is attributed mainly to $\mathrm{Ni}$ metal. The rapid initial deactivation of the catalyst observed in all the experiments is assigned to the deactivation of support activity which is mainly due to accumulation of coke and strongly adsorbed species on the support surface. Ni particles can help the reforming of acetone formed on support within the proximity of Ni particles to syngas via reaction (10). This explains the very low yield of acetone in the case of supported Ni catalyst compared with reforming in presence of bare support (Figure 6.1 and Figure 6.3). In addition, when steam reforming acetone at 700 ${ }^{\circ} \mathrm{C}$ with WHSV $6.96 \mathrm{~h}^{-1}$ with this catalyst (not shown here), total yield of $\mathrm{CO}_{\mathrm{x}}$ and $\mathrm{CH}_{4} \sim 95 \pm$ $2 \%$ (yield of $\mathrm{CH}_{4} \sim 1 \%$ ) was achieved. Thus, that confirms the catalyst is capable of reforming acetone to syngas. Therefore, if acetone is formed on Ni during steam acetic acid reforming, it would be expected to be converted to syngas rapidly. Coke formed on Ni via ketonisation or condensation, reaction (11) - (15), is therefore unlikely. Thus, the coke deposition under the influence of supported $\mathrm{Ni}$ is more likely to involve recombination of unconverted active carbon rich radicals via reaction (16). This coke can be much more graphitised than the coke formed on the support via condensation of ketones. The high oxidation temperature of coke deposits on the catalyst after run 1 (Figure 6.8) is the result of graphitisation of unconverted active, rich $\mathrm{C}$ radical.

It is remarkable that the overall activity of the catalyst for steam reforming reactions is improved with the recycled catalysts (Figure 6.4). Usually the increase in activity (or conversion) is attributed to the increase of number of active sites. From LEIS result, no increase of $\mathrm{Ni}$ peak compared with $\mathrm{Zr}$ and $\mathrm{Ce}$ is observed. Therefore, increase in number of metal particles after recycling is improbable in this case. Importantly, the increase of CO yield is in accordance to the gain of $\mathrm{AcOH}$ conversion without any change in yield of $\mathrm{CO}_{2}$. If the additional acetic acid is converted via decarboxylation route that means $* \mathrm{CH}_{3}$ and $\mathrm{CO}_{2}$ is made with $1 / 1$ molar ratio. To keep the $\mathrm{CO}_{2}$ yield constant, the all extra $\mathrm{CO}_{2}$ have to be consumed. Reactions involving the consumption of $\mathrm{CO}_{2}$ include dry reforming of hydrocarbon radial and reverse water gas shift (RWGS). Since dry reforming is more difficult than steam reforming, it is not possible that all the additional ${ }^{*} \mathrm{CH}_{3}$ radical is only reformed by $\mathrm{CO}_{2}$ yet by steam. On the other hand, the concentration $\mathrm{CO}$ in gas stream is higher than the thermodynamic equilibrium concentration (at $700{ }^{\circ} \mathrm{C}, 1 \mathrm{~atm}$, selectivity of $\mathrm{CO}$ at equilibrium is $\sim 8.3 \%$ ). Thus, RWGS reaction is not probable. With all those analysis points, additional conversion of acetic acid via decarboxylation as the first step can be ruled out. The route via reactions (9) is not possible either because it also makes $\mathrm{CO}_{2}$ as the first step. Therefore, the additional acetic acid is probably converted via dehydration route for formation of ketene - 
reaction (7). Subsequently, ketene can either decompose to $\mathrm{CO}$ and methylene by $\mathrm{C}-\mathrm{C}$ cleavage via reaction (7) or be converted to acetone by coupling with another ketene to form acetone and $\mathrm{CO}[26]$.

There have been a lot of debates about the role of ketene in the mechanism of ketonisation reactions of acetic acid. A recent review by Pham et al.[33] provided a good summary on various proposed mechanisms for this reaction. In typical condition for ketonisation (e.g., $\mathrm{T}$ max below $600{ }^{\circ} \mathrm{C}$, only metal oxide as catalyst, long contact time), it usually involves decarboxylation step. Lemonidou et al. [26] investigated TPD of acetic acid on $\mathrm{Rh} / \mathrm{La}_{2} \mathrm{O}_{3}-\mathrm{CeZrO}_{2}$ catalyst and found that formation of acetone was followed by $\mathrm{CO}$ instead of $\mathrm{CO}_{2}$. Therefore, they proposed acetone was formed by condensation of two ketene molecules - reaction (19). In the same paper, the decarbonylation of ketene for ${ }^{*} \mathrm{CH}_{2}$ was included as the main pathway of ketene conversion which contribute to reforming activity of the catalyst. We leave the possibility of reaction (19) open here since our catalyst system resembles quite well to the one used in that literature. Additionally, the activity improvement can be seen throughout the whole reaction time, above $30 \mathrm{~h}$ TOS, this suggests that the gained active sites are located in the proximity of Ni particles. Thus, the adsorbed intermediates on these sites can get the influence of reforming activity of Ni. If these intermediates are away from $\mathrm{Ni}$, they tend to form coke which will block these sites after short times on stream. In any scenarios of intermediates on these gained active sites, it is assured that improvement of reducibility of the support can enhance the adsorption of deprotonated acetic acid [31, 33]. Also, the $\mathrm{CeO}_{2}-\mathrm{ZrO}_{2}$ supported $\mathrm{Ni}$ catalyst is capable of steam reforming acetone. The recycled catalyst shows $c a$. $100 \%$ conversion of acetone to syngas after $24 \mathrm{~h}$ TOS (not shown here).

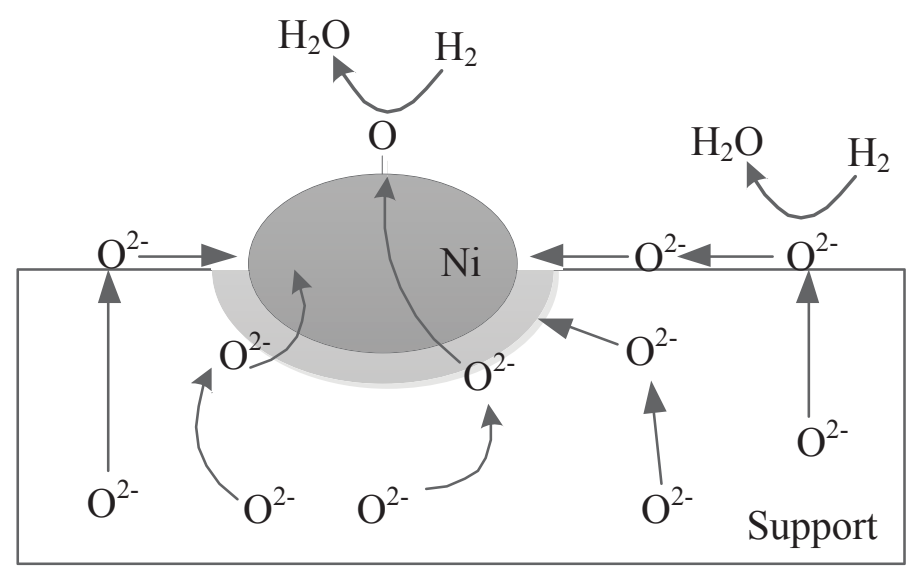

Scheme 6.2. Oxygen migration of oxygen under reductive condition illustrated in the case of $\mathrm{H}_{2}$. During steam reforming the reducing agents are $* \mathrm{CH}_{\mathrm{x}}$ or coke precursor. 
Another factor which contributes to the higher activity of the recycled catalyst is the capability of minimizing coke deposits on the catalyst. Raman spectroscopy indicates weaker bonds between metal cation and $\mathrm{O}$ anion on the recycled catalyst (Figure 6.7). This in turn means oxygen becomes more labile and mobile. The TPR result is in accordance with Raman result. The support itself becomes more easily to be reduced after exposing to steam reforming conditions. Although the reduction $\left(\right.$ in $\mathrm{H}_{2}$ ) and oxidation in $\mathrm{O}_{2}$ can provide certain improvement of redox properties, the presence of oxidative/reductive elements in steam reforming (e.g., steam, $\mathrm{CO}_{2}$, coke, acetic acid etc.) seems to make more improvements in the reducibility of the supports. This can be seen even more clearly with the supported Ni catalysts. There is no clear change in TPR profile of fresh catalyst after several oxidation/reduction cycles but surely for the recycled catalysts. In the latter case, the major part of the catalyst support is reduced in the same range of Ni particle (Figure 6.9) implies possible interactions between them. Spill-over of oxygen from the support to Ni particles can probably take place. It should be noted that this phenomena applies for bulk phase migration of $\mathrm{O}^{2-}$ anion, i.e. oxygen from sub-lattice to the surface and interphase with Ni particles and $\mathrm{O}$ from surface of the mixed oxide to surface of Ni (illustrated in Scheme 6.2). As known from literature [34], migration of $\mathrm{O}^{2-}$ from bulk phase to the surface is the rate limiting steps of reduction.

During steam reforming of acetic acid, $\mathrm{Ce}^{3+}$ can be re-oxidised by $\mathrm{H}_{2} \mathrm{O}$. The more labile $\mathrm{O}$ or $\mathrm{OH}$ on the surface of recycled catalyst can improve the oxidation of the coke precursors absorbed on the support. Moreover, that mobile O can spill-over to Ni particles to help the oxidation of carbon radical (e.g. ${ }^{*} \mathrm{CH}, \mathrm{C}^{*}$ species), thus preventing the graphitisation of coke. The improvement of redox properties results in less coke content, preventing transformation via aging to hard coke which can be seen from TPO. Lower extend of coking also help to decrease the deactivation of catalyst.

\subsection{Conclusion}

Supported Ni on ceria-zirconia catalyst shows high activity and stability for steam reforming of acetic acid. The steam reforming condition creates extra modification on the metal - oxygen bonds of the oxide support compared with thermal ageing treatment. Under the reforming condition, oxygen in the lattice becomes more labile. Thus steam reforming elements (e.g., presence of $\mathrm{H}_{2} \mathrm{O}$, acetic acid, coke, long exposure to reductive/oxidative agents etc.) improve the oxygen mobility of the catalyst, facilitating the redox coupling of $\mathrm{Ce}^{3+} / \mathrm{Ce}^{4+}$. Higher activity of recycled catalyst suggests implementation of ageing pre-treatment in similar reforming condition can be applied to improve the stability and activity of the catalyst. In addition, the catalyst is highly potential for steam reforming of the whole volatile stocks 
from humin gasification. Since bio-derived oils (e.g., pyrolysis oil, high pressure liquefaction oil) contain similar components to humin volatiles, we strongly believe that this catalyst is also promising for the steam reforming of these bio-oils.

\section{Bibliography}

[1] T.M.C. Hoang, L. Lefferts, K. Seshan, Valorization of humin-based byproducts from biomass processing-a route to sustainable hydrogen, ChemSusChem, 6 (2013) 1651-1658.

[2] T.M.C. Hoang, E.R.H. Van Eck, W.P. Bula, J.G.E. Gardeniers, L. Lefferts, K. Seshan, Humin based by products from bioprocessing as potential carbonaceous source for synthesis gas production, Green Chemistry, (submitted) (2014).

[3] T.M.C. Hoang, N. Koteswara Rao, L. Lefferts, K. Seshan, Investigation of Ce-Zr oxide supported Ni catalysts in steam reforming of meta-cresol as model component for bio-derived tar, ChemSusChem, submitted (2014).

[4] A.C. Basagiannis, X.E. Verykios, Catalytic steam reforming of acetic acid for hydrogen production, International Journal of Hydrogen Energy, 32 (2007) 3343-3355.

[5] A.C. Basagiannis, X.E. Verykios, Reforming reactions of acetic acid on nickel catalysts over a wide temperature range, Applied Catalysis A: General, 308 (2006) 182-193.

[6] A.C. Basagiannis, X.E. Verykios, Influence of the carrier on steam reforming of acetic acid over Ru-based catalysts, Applied Catalysis B: Environmental, 82 (2008) 77-88.

[7] K. Takanabe, K. Aika, K. Seshan, L. Lefferts, Catalyst deactivation during steam reforming of acetic acid over Pt/ZrO2, Chemical Engineering Journal, 120 (2006) 133-137.

[8] B. Matas Güell, I.M. Torres da Silva, K. Seshan, L. Lefferts, Sustainable route to hydrogen - Design of stable catalysts for the steam gasification of biomass related oxygenates, Applied Catalysis B: Environmental, 88 (2009) 59-65.

[9] B. Matas Güell, I. Babich, K.P. Nichols, J.G.E. Gardeniers, L. Lefferts, K. Seshan, Design of a stable steam reforming catalyst-A promising route to sustainable hydrogen from biomass oxygenates, Applied Catalysis B: Environmental, 90 (2009) 38-44.

[10] L. An, C. Dong, Y. Yang, J. Zhang, L. He, The influence of Ni loading on coke formation in steam reforming of acetic acid, Renewable Energy, 36 (2011) 930-935.

[11] G. Colón, M. Pijolat, F. Valdivieso, H. Vidal, J. Kašpar, E. Finocchio, M. Daturi, C. Binet, J.C. Lavalley, R.T. Baker, S. Bernal, Surface and structural characterization of CexZr1$\mathrm{xO} 2$ CEZIRENCAT mixed oxides as potential three-way catalyst promoters, Journal of the Chemical Society, Faraday Transactions, 94 (1998) 3717-3726.

[12] G. Nahar, V. Dupont, Hydrogen production from simple alkanes and oxygenated hydrocarbons over ceria-zirconia supported catalysts: Review, Renewable and Sustainable Energy Reviews, 32 (2014) 777-796. 
[13] F. Fally, V. Perrichon, H. Vidal, J. Kaspar, G. Blanco, J.M. Pintado, S. Bernal, G. Colon, M. Daturi, J.C. Lavalley, Modification of the oxygen storage capacity of $\mathrm{CeO} 2-\mathrm{ZrO} 2$ mixed oxides after redox cycling aging, Catalysis Today, 59 (2000) 373-386.

[14] H. Vidal, J. Kašpar, M. Pijolat, G. Colon, S. Bernal, A. Cordón, V. Perrichon, F. Fally, Redox behavior of CeO2-ZrO2 mixed oxides, Applied Catalysis B: Environmental, 30 (2001) $75-85$.

[15] R. Di Monte, J. Kašpar, Nanostructured CeO2-ZrO2 mixed oxides, Journal of Materials Chemistry, 15 (2005) 633.

[16] J. Fan, X. Wu, R. Ran, D. Weng, Influence of the oxidative/reductive treatments on the activity of Pt/Ce0.67Zr0.33O2 catalyst, Applied Surface Science, 245 (2005) 162-171.

[17] T. Hirata, Raman-active modes and the tetragonal-monoclinic phase transition in $\mathrm{ZrO} 2$ doped with 12mol\% CeO2, Journal of Physics and Chemistry of Solids 56 (1995) 951-957.

[18] D.J. Kim, J.W. Jang, H.L. Lee, Effect of tetravalent dopants on Raman spectra of tetragonal zirconia, J Am Ceram Soc, 80 (1997) 1453-1461.

[19] S. Agarwal, L. Lefferts, B.L. Mojet, Ceria Nanocatalysts: Shape Dependent Reactivity and Formation of $\mathrm{OH}$, ChemCatChem, 5 (2013) 479-489.

[20] H. Vidal, J. Kašpar, M. Pijolat, G. Colon, S. Bernal, A. Cordón, V. Perrichon, F. Fally, Redox behavior of $\mathrm{CeO} 2-\mathrm{ZrO} 2$ mixed oxides I. Influence of redox treatments on high surface area catalysts, Applied Catalysis B: Environmental, 27 (2000) 49-63.

[21] I. Kosacki, T. Suzuki, H.U. Anderson, P. Colomban, Raman scattering and lattice defects in nanocrystalline $\mathrm{CeO} 2$ thin films, Solid State Ionics, 149 (2002) 99-105.

[22] R. Si, Y.-W. Zhang, S.-J. Li, B.-X. Lin, C.-H. Yan, Urea-Based Hydrothermally Derived Homogeneous Nanostructured $\mathrm{Ce} 1-\mathrm{xZrxO} 2(\mathrm{x}=0-0.8)$ Solid Solutions: A Strong Correlation between Oxygen Storage Capacity and Lattice Strain, The Journal of Physical Chemistry B, 108 (2004) 12481-12488.

[23] S. Letichevsky, C.A. Tellez, R.R.d. Avillez, M.I.P.d. Silva, M.A. Fraga, L.G. Appel, Obtaining $\mathrm{CeO} 2-\mathrm{ZrO} 2$ mixed oxides by coprecipitation: role of preparation conditions, Applied Catalysis B: Environmental, 58 (2005) 203-210.

[24] M. Kuhn, S.R. Bishop, J.L.M. Rupp, H.L. Tuller, Structural characterization and oxygen nonstoichiometry of ceria-zirconia $(\mathrm{Ce} 1-\mathrm{xZrxO}-\delta)$ solid solutions, Acta Materialia, 61 (2013) 4277-4288.

[25] E.C. Vagia, A.A. Lemonidou, Investigations on the properties of ceria-zirconiasupported $\mathrm{Ni}$ and $\mathrm{Rh}$ catalysts and their performance in acetic acid steam reforming, Journal of Catalysis, 269 (2010) 388-396. 
[26] A.A. Lemonidou, E.C. Vagia, J.A. Lercher, Acetic acid reforming over Rh supported on La2O 3/CeO2-ZrO2: Catalytic performance and reaction pathway analysis, ACS Catalysis, 3 (2013) 1919-1928.

[27] H. Vidal, S. Bernal, J. Kašpar, M. Pijolat, V. Perrichon, G. Blanco, J.M. Pintado, R.T. Baker, G. Colon, F. Fally, Influence of high temperature treatments under net oxidizing and reducing conditions on the oxygen storage and buffering properties of a $\mathrm{Ce} 0.68 \mathrm{Zr} 0.32 \mathrm{O} 2$ mixed oxide, Catalysis Today, 54 (1999) 93-100.

[28] P. Fornasiero, G. Balducci, R. Di Monte, J. Kašpar, V. Sergo, G. Gubitosa, A. Ferrero, M. Graziani, Modification of the redox behaviour of $\mathrm{CeO} 2$ induced by structural doping with ZrO2, Journal of Catalysis, 164 (1996) 173-183.

[29] K. Takanabe, K.I. Aika, K. Seshan, L. Lefferts, Sustainable hydrogen from bio-oil Steam reforming of acetic acid as a model oxygenate, Journal of Catalysis, 227 (2004) 101108.

[30] R. Pestman, R.M. Koster, A. van Duijne, J.A.Z. Pieterse, V. Ponec, Reactions of Carboxylic Acids on Oxides: 2. Bimolecular Reaction of Aliphatic Acids to Ketones, Journal of Catalysis, 168 (1997) 265-272.

[31] K.S. Kim, M.A. Barteau, Structure and composition requirements for deoxygenation, dehydration, and ketonization reactions of carboxylic acids on TiO2(001) single-crystal surfaces, Journal of Catalysis, 125 (1990) 353-375.

[32] R. Martinez, M.C. Huff, M.A. Barteau, Ketonization of acetic acid on titaniafunctionalized silica monoliths, Journal of Catalysis, 222 (2004) 404-409.

[33] T.N. Pham, T. Sooknoi, S.P. Crossley, D.E. Resasco, Ketonization of carboxylic acids: Mechanisms, catalysts, and implications for biomass conversion, ACS Catalysis, 3 (2013) 2456-2473.

[34] P. Fornasiero, J. Kašpar, M. Graziani, On the rate determining step in the reduction of CeO2-ZrO2 mixed oxides, Applied Catalysis B: Environmental, 22 (1999) L11-L14.

\section{Appendix 6}

\section{A1. Calculation of Acetic acid conversion}

The conversion of acetic acid during the steam reforming with presence of supported $\mathrm{Ni}$ catalysts is calculated based on 2 main cumulative reactions below:

$$
\begin{aligned}
& \mathrm{CH}_{3} \mathrm{COOH}+2 \mathrm{H}_{2} \mathrm{O} \rightarrow 2 \mathrm{CO}_{2}+4 \mathrm{H}_{2} \\
& \mathrm{CH}_{3} \mathrm{COOH} \rightarrow 2 \mathrm{CO}+2 \mathrm{H}_{2}
\end{aligned}
$$


Denote:

a [g/min]: amounts of $\mathrm{AcOH}$ is converted via $\mathrm{Eq} 1$

$\mathrm{b}[\mathrm{g} / \mathrm{min}]$ : amounts of $\mathrm{AcOH}$ is converted via $\mathrm{Eq} 2$

$\mathrm{C}_{0}[\mathrm{~g} / \mathrm{ml}]$ : concentration of the m-cresol solution delivered by the pump to the evaporator

$\mathrm{C}[\mathrm{g} / \mathrm{ml}]$ : concentration of the liquid collected in the flash separator which is quantified by HPLC

d $[\mathrm{g} / \mathrm{ml}]$ : density of pure AcOH, 1.047 [g/ml]

$\mathrm{F}[\mathrm{ml} / \mathrm{min}]$ : flowrate of $\mathrm{AcOH}$ solution delivered by the pump

Call:

$$
\mathrm{n}=\frac{\text { mole of } \mathrm{CO}}{\text { mole of } \mathrm{CO}_{2}} \rightarrow \mathrm{n}=\frac{\mathrm{b}}{\mathrm{a}}
$$

The amount of $\mathrm{AcOH}$ is supplied into the reactor $[\mathrm{g} / \mathrm{min}]=\mathrm{C}_{0} \cdot \mathrm{F}$

The amount of unconverted $\mathrm{AcOH}[\mathrm{g} / \mathrm{min}]$

$$
\mathrm{C}_{0} \cdot \mathrm{F}-(\mathrm{a}+\mathrm{b})=\mathrm{C}_{0} \cdot \mathrm{F}-\mathrm{a} \cdot(\mathrm{n}+1)
$$

The amount of water consumed in Eq 1 and Eq $2[\mathrm{~g} / \mathrm{min}]$ :

$$
\frac{2 \times 18}{60} \cdot \mathrm{a}=0.6 \cdot \mathrm{a}
$$

The total volume of liquid condensed after the reactor $[\mathrm{ml} / \mathrm{min}]$ :

$$
\mathrm{F}-\frac{\mathrm{a}+\mathrm{b}}{\mathrm{d}}-0.6 \cdot \mathrm{a}=\mathrm{F}-\frac{\mathrm{n}+1}{\mathrm{~d}} \cdot \mathrm{a}-0.6 \cdot \mathrm{a}
$$

From (1) and (2):

$$
\mathrm{C}_{0} \cdot \mathrm{F}-\mathrm{a} \cdot(\mathrm{n}+1)=\mathrm{C} \cdot\left(\mathrm{F}-\frac{\mathrm{n}+1}{\mathrm{~d}} \cdot \mathrm{a}-0.6 \cdot \mathrm{a}\right)
$$

Solving equation (3)

$$
\rightarrow \mathrm{a}=\frac{\mathrm{d} \cdot \mathrm{F} \cdot\left(\mathrm{C}_{0}-\mathrm{C}\right)}{(\mathrm{n}+1) \cdot(\mathrm{d}-\mathrm{C})-0.6 \cdot \mathrm{C}}
$$

Conversion of $\mathrm{AcOH}$ :

$$
\mathrm{X}=\frac{\mathrm{a}+\mathrm{b}}{\mathrm{F} \cdot \mathrm{C}_{0}}=\frac{\mathrm{a} \cdot(\mathrm{n}+1)}{\mathrm{F} \cdot \mathrm{C}_{0}}
$$

Replace a from (4) to (5), conversion is obtained as following:

$$
\begin{aligned}
X & =\frac{\mathrm{n}+1}{\mathrm{~F} \cdot \mathrm{C}_{0}} \cdot \frac{\mathrm{d} \cdot \mathrm{F} \cdot\left(\mathrm{C}_{0}-\mathrm{C}\right)}{(\mathrm{n}+1) \cdot(\mathrm{d}-\mathrm{C})-0.6 \cdot \mathrm{C}} \\
\rightarrow \mathrm{X} & =\frac{\mathrm{n}+1}{\mathrm{C}_{0}} \cdot \frac{\mathrm{d} \cdot\left(\mathrm{C}_{0}-\mathrm{C}\right)}{(\mathrm{n}+1) \cdot(\mathrm{d}-\mathrm{C})-0.6 \cdot \mathrm{C}}
\end{aligned}
$$

$\mathrm{C}$ and $\mathrm{C}_{0}$ is determined from HPLC.

$\mathrm{n}$ is estimated from $\mathrm{GC}$ result. 


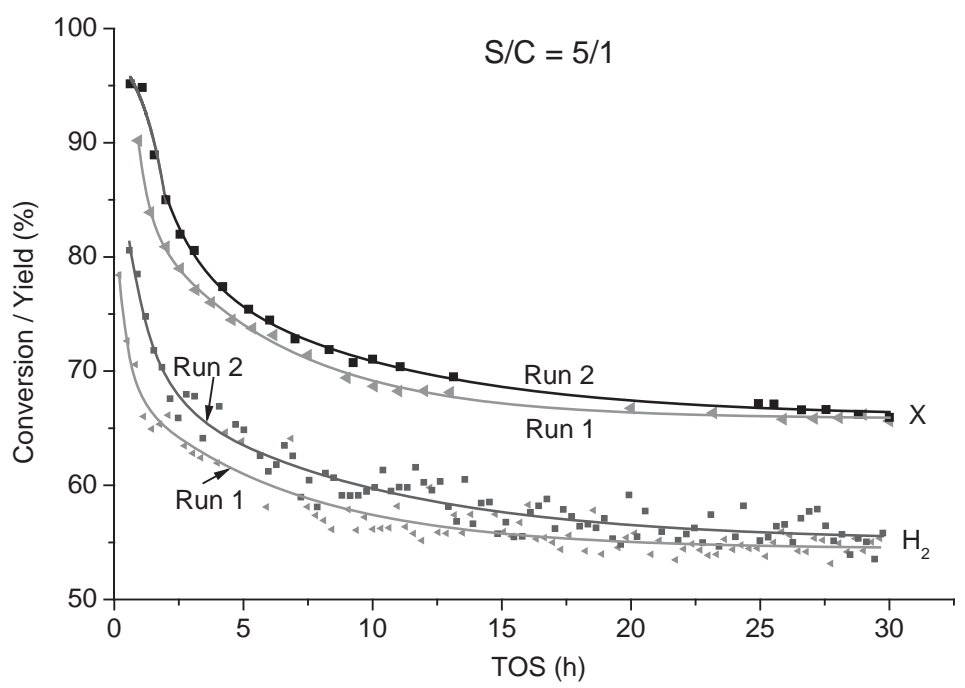

Figure A.6.1 Influence of catalyst recycle on steam reforming of $\mathrm{AcOH}$ in the case $\mathrm{S} / \mathrm{C}$ ratio of $5\left(\mathrm{~T}=700{ }^{\circ} \mathrm{C}, \mathrm{WHSV}=25.2 \mathrm{~h}^{-1}\right)$

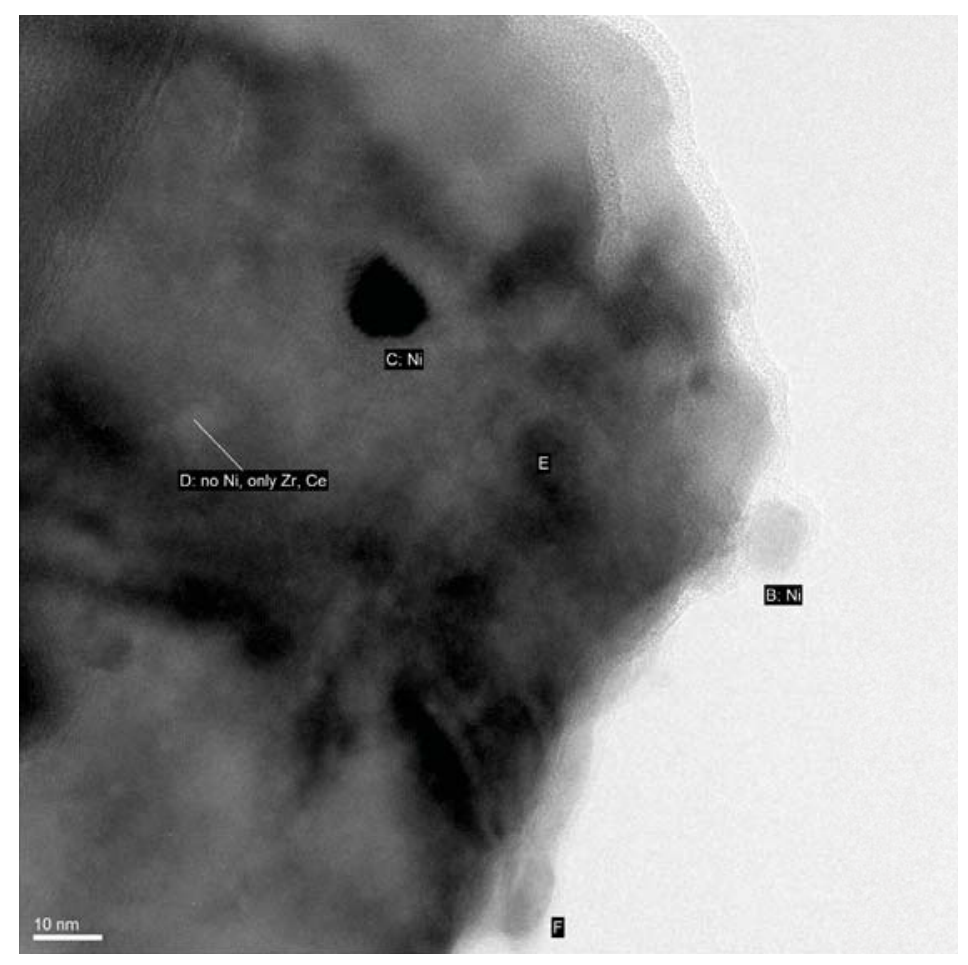

Figure A.6.2. TEM image of fresh $\mathrm{Ni} / \mathrm{HT}$ catalyst 


\title{
Concluding remarks and outlook
}

\begin{abstract}
Concluding remarks about gasification of humin from results reported in this thesis are summarised. An initial process design was proposed taking into account technical aspects such as gas processing, catalysts for the conversion and energy management. Recommendations for further studies on gasification of humin as well as optimisation and characterisation of supported catalysts are also included.
\end{abstract}




\subsection{Concluding remarks}

Over the last hundred years, the living standards have changed tremendously developed based on the advances in industrial technology. In terms of fuel and materials, $20^{\text {th }}$ century has also marked the use and domination of petroleum refinery. However, mankind today consumes fossil fuel at the rate that is much faster than that of fossil feedstock exploration and development. The discovery and invention in technology which allows to extract difficult resources such as shale gas only can give us some more time until the critical moment: fossil reserves cannot meet our daily demands of feedstock for fuel and chemicals even in the near future. Moreover, burning fossil fuels is one of the biggest causes for the global warming. These problems have generated a lot of interest in searching for the sustainable alternatives.

Lignocellulosic biomass is considered as the only carbon-containing, renewable alternative resource for our fuels and materials. Biorefinery concepts are proposed as guidelines for making energy, fuels and chemicals from different components of biomass. The conversion of (hemi)celluloses is important in the biorefinery scheme since they comprise 70 - 80 wt. $\%$ of biomass. Furans (HMF, FF, FDCA) and levulinic acid are in the list of final Top Ten value added chemical platforms from carbohydrates which include hemicellulose and cellulose. The conversion of carbohydrate to those molecules requires depolymerisation of polysaccharides for sugars and dehydration of corresponding sugar to HMF, FF or LA. One of the major problem in such conversion is the formation of large amounts of solid by-products, namely humin.

A lot of effort has been paid on suppression of humin formation in the sugar conversion processes. However, it requires use of expensive solvent (e.g., ionic liquids), difficulty and high energy input required for product separation. In the meantime for achieving breakthrough in the conversion technology, valorisation of the humin by-product should be taken into account to improve the economic value and environmental factor of whole bioprocess. Since hydrogen is omnipresent in biorefinery, the approach for producing hydrogen from humin is conceptually attractive. This can provide green hydrogen for downstream processing in biorefinery.

Although the presence of humin was reported in almost every single literature on HMF, LA synthesis, its chemical structure, properties or useful conversion is not well understood. Furthermore, use of humin is usually mentioned in a few words for the possibility of generating heat. To the best of our knowledge, serious research on application of humin with regard to gasification has not been reported in literature. The objective of this research is about investigating the potential of humin for gasification to produce sustainable 
hydrogen/synthesis gas. The fundamental study on the chemical structure of humin as well as its characteristics during the gasification has been elaborated. The whole gasification process (e.g., de-volatilisation stage, dry/steam reforming stage, removal of tar) has been considered and investigated so that complete process scheme can be established for a conceptual design in this thesis.

The pristine humin can embed considerable amounts of extractable components $(8-16$ wt.\%) which are (by)products derived from the dehydration of sugars (e.g., HMF, LA, soluble humin). Results of spectroscopy analysis (ATR-IR, ${ }^{13} \mathrm{C}$ solid state MAS NMR) as well as the pyrolysis data helped to understand the structure of humin. The humin framework consists of furanic segments with aliphatic linkages decorated by carboxylic and ketone groups. Mass spectrometry (ESI-MS, GPC, LDI-TOF) indicated the abundant presence of the mass 301 Dalton. By combining those data, a proposal of the chemical structure of humin segments, and possible structure of humin has been made.

In the first stage of the gasification (in steam and/or $\mathrm{CO}_{2}$ ), i.e. pyrolysis or devolatilisation stage, humin undergoes drastic changes in morphology, composition and chemical structure. During this stage, humin turned from a dense to a porous structure due to the decomposition of functional groups and escape of the volatiles. Even in $\mathrm{CO}_{2}$ reforming, hollow spherical particles were formed which indicated the asymmetric composition of humin. The most important knowledge obtained about this stage in gasification, is that humin becomes more and more aromatised/graphitised resulting in very high carbon content (above 90 wt.\%) and it lost about $25 \%$ carbon into vapour phase in the form of gas $\left(\mathrm{CO}, \mathrm{CO}_{2}\right)$ and organic volatiles (e.g., phenols, acetic acid, poly-aromatics). In some cases, traces of $\mathrm{S}$ containing species such as DMSO-2 were present in the volatile stream (S containing species released at temperature below $400{ }^{\circ} \mathrm{C}$ ). Caution for processing the vapour/gas stream should be exercised since these species can cause deactivation of catalyst in downstream reactors. The results also indicate that the gasification of humin resembles to that of coal or bio-char and consideration should be taken for removal of the volatiles in the product gas stream.

Humin shows low reactivity towards steam $/ \mathrm{CO}_{2}$ reforming, thus thermal gasification of humin requires very high temperature (above $1050{ }^{\circ} \mathrm{C}$ ). Alkali metal carbonates are active for gasification. Sodium carbonate showed highest activity and it was selected for further investigation. Activation energy for dry reforming in presence of sodium carbonate is in the range for bio-char gasification. The kinetics study on steam and dry reforming of humin reveals that the conversion rate is quite stable over wide range of conversions (conversion is proportional to TOS) and the catalytic reforming resembles bulk reaction. Complete conversion can be achieved for steam reforming in the presence of presence of $\mathrm{Na}_{2} \mathrm{CO}_{3}$ 
(selectivity to $\mathrm{CO}$ and $\mathrm{CO}_{2}$ is 75 and $25 \%$, respectively; $\mathrm{H}_{2} / \mathrm{CO} \sim 2$ ), however, loss of catalyst into gas phase was observed and explained by the transformation of $\mathrm{Na}_{2} \mathrm{CO}_{3}$ to more volatile species (e.g., $\mathrm{Na}, \mathrm{Na}_{2} \mathrm{O}_{2}$ ). Addition of $\mathrm{CO}_{2}$ to the feed stream for steam reforming increases the stability of $\mathrm{Na}_{2} \mathrm{CO}_{3}$ tremendously. Therefore, for a conceptual design, it is required that combining $\mathrm{CO}_{2}$ and steam for the catalytic gasification is essential. Implementation of WGS step after gasification is to increase the $\mathrm{H}_{2}$ production yields.

For the steam reforming of volatiles (tar type products) released from humin during heating to the gasification temperatures, non-noble catalyst systems consisting of supported $\mathrm{Ni}$ on ceria-zirconia solid solutions were developed with a preference to influence properties of support via varying synthesis parameters. The use of m-cresol and acetic acid as model components for the volatiles of humin covers most of chemical functionalities for the vapour mixture. Ceria-zirconia mixed oxide has good redox properties which can contribute to the oxidation of coke deposits on catalyst thus preventing catalyst deactivation. The synthesis of ceria-zirconia oxide, indeed, was also essential for improving the redox properties of the support (in term of oxygen capacity and oxygen mobility) to help enhance gasification. This is the reason for stable, high activity of the supported $\mathrm{Ni}$ on $\mathrm{Ce}-\mathrm{Zr}$ catalyst prepared via coprecipitation followed by hydrothermal treatment compared with conventional impregnation deposition of $\mathrm{Ce}$ on $\mathrm{ZrO}_{2}$ in steam reforming of m-cresol. The stability of this catalyst is also demonstrated in steam reforming of acetic acid, a component well-known for causing catalyst deactivation in steam reforming of bio-derived feedstocks. The improvement in activity of the recycled catalyst has been suggested to be caused by increase of oxygen mobility in the case of recycled catalyst. Modification of $\mathrm{Ce}$ or $\mathrm{Zr}$ - $\mathrm{O}$ bonds happen under the redox treatment or gasification conditions, especially in the latter case - steam reforming of acetic acid. Characterisation of the catalysts indicates the gain active sites locating in proximity of $\mathrm{Ni}$ particles where the deprotonated acetic acid was adsorbed and converted via dehydration pathway.

For steam reforming of $\mathrm{m}$-cresol, the supported $\mathrm{Ni}$ was attributed to influence the main activity for $\mathrm{C}-\mathrm{C}$ and $\mathrm{C}-\mathrm{H}$ cleavage (of $\mathrm{m}$-cresol). The in situ FT-IR study revealed the horizontal adsorption of the aromatic rings on the Ni surface and interaction of methyl group with the support. This allows multiple cleavages to occur at the same time on the catalyst. Since manifold sites including $\mathrm{Ni}$ involve in the reforming of $\mathrm{m}$-cresol, relatively large $\mathrm{Ni}$ crystallites (within optimum range) are more favoured.

The supported $\mathrm{Ni}$ on $\mathrm{Ce}-\mathrm{Zr}$ catalyst prepared via co-precipitation followed by hydrothermal treatment compared is the best of the three designed catalysts. This catalyst 
shows great promise for industrial applications, not only for humin gasification but also for steam reforming of bio oil or tar reforming in biomass gasification.

\section{2. $\quad$ Proposed conceptual design}

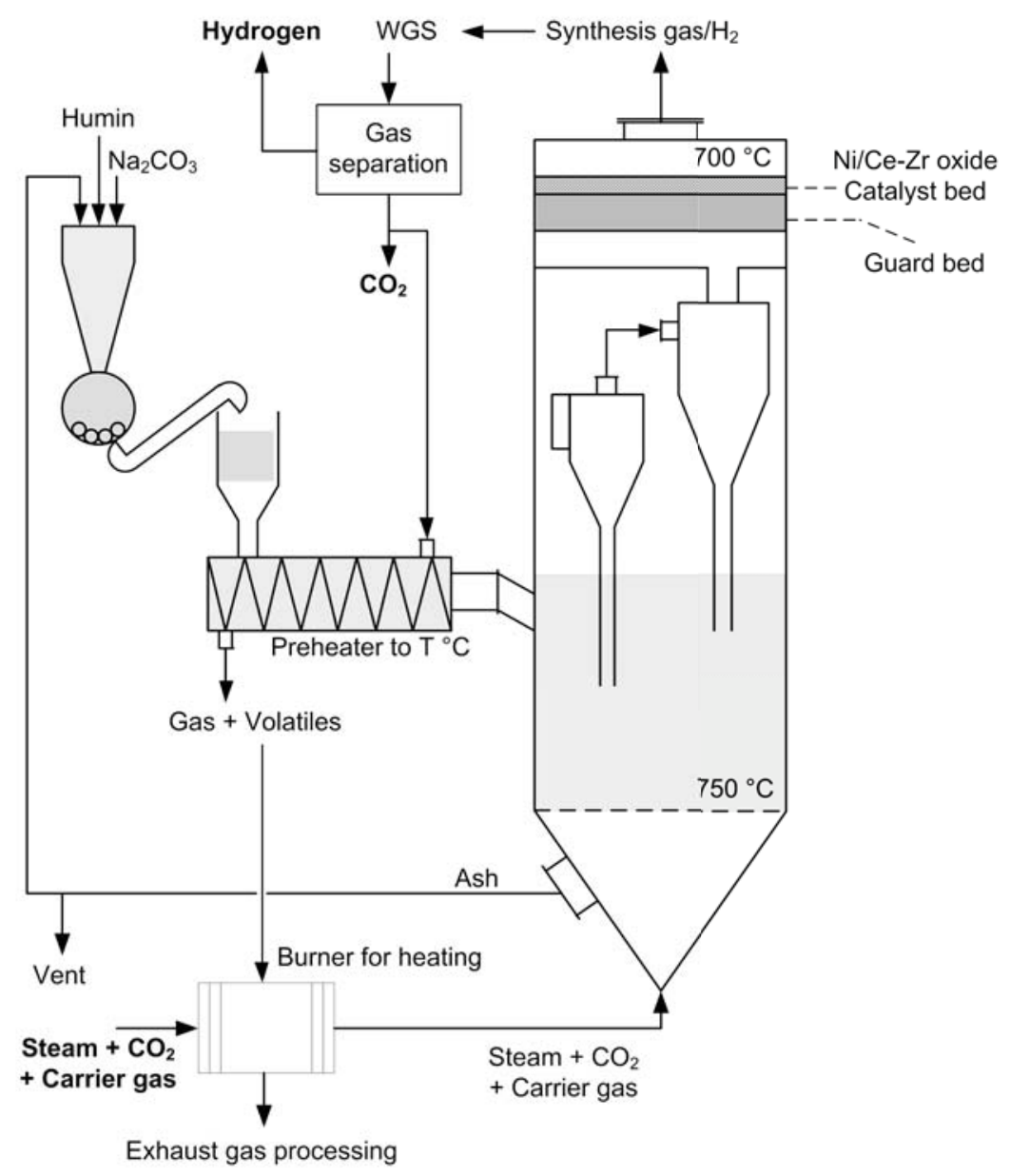

Figure 7.1. Proposed process scheme for steam reforming of humin

In chapter 3, a scheme for complete conversion of humin was proposed. For a conceptual design of the process, more technical aspects such as impurities in the humin feedstock, especially residues from inorganic acids used in the dehydration step, feedstock and product processing is required and considered carefully. Similar to the approach of biorefinery, the design and use of material and energy streams should be integrated with the conversion of sugars or the downstream processes (e.g., synthesis gas processing, conversion of chemical building platforms - for instance, levulinic acid to $\gamma$-valerolactone).

In this study sulphuric acid was used as catalyst for the dehydration of glucose. The sulphur content in humin is due to certain extent of sulfonation. The presence of sulphur would not affect the gasification of solid humin residue which uses sodium carbonate as 
catalyst. However, it can cause deactivation to supported $\mathrm{Ni}$ catalysts used for reforming of humin tar. Release of molecules such DMSO-2 is only observed in the early stage of devolatilisation, thus, it is possible to separate the gas stream containing impurity by stepwise pre-heating. Moreover, in practice, other inorganic acids such as $\mathrm{HCl}$ are also widely used for the dehydration step. In that case, the issue of chlorine containing species needs to be considered.

Steam reforming of humin residue requires a lot of energy since steam or dry reforming of carbon reactions is highly endothermic. Energy required for this stage should come from sustainable source, too. Humin or its products can also be used for generating heat. With that regard, the harmful volatiles such as $\mathrm{S}$ containing species can be combusted for heat production.

Taking all these remarks above as well as the results presented in the thesis, conceptual steps for gasification of humin is proposed and illustrated in Figure 7.1. Sodium carbonate and humin are mixed together in grinding machine. A skew preheater with cross flows can be used for heating humin to a temperature above $400{ }^{\circ} \mathrm{C}$. While the preheated humin residue can be transferred to feeder of the gasifier, the heat carrier stream containing gas and volatiles of humin (e.g., $\mathrm{CO}_{2}, \mathrm{CO}$, furan, acetic acid, aromatics) released can be sent to the combustion furnace for generating heat. It also helps to diminish the amounts of sulphur and acetic acid to the gasifier and maximise the use of carbon source in humin. In Figure 7.1, the main gasifier is illustrated as a fluidization reactor since this reactor design provides good heat and mass transfer. The physical strength of humin is much lower than biomass or coal since it is only agglomerates of small particles. It is easy to prepare humin (by grinding) to small particle size. Therefore besides fluidised bed reactor, entrained flow gasifier can also be used.

For maximising the yield of hydrogen, WGS step is mandatory since the gas stream from gasifier of solid humin residue contains large amount of $\mathrm{CO}$ (in steam only, selectivity of $\mathrm{CO}_{2} / \mathrm{CO}$ is $\left.25 / 75\right) . \mathrm{CO}_{2}$ after the gas separation preceded by WGS step can be used for 3 purposes: (1) heat carrier for preheating of humin; (2) co-feeding to the gasifier with steam for stabilising sodium catalyst; (3) the excess $\mathrm{CO}_{2}$ can be pressurised and stored for used in other process in biorefinery (e.g., extraction of biomass with supercritical $\mathrm{CO}_{2}$ ).

\subsection{Recommendations}

This process shows positive primary economic value and promise for producing green hydrogen. The proposed conceptual design here can be the first step for the further optimisation of the process, which will be carried out in the next phase of the project. 
The chemical model of humin that is proposed in chapter 2 needs validation. LC-MS combining with NMR can provide more details about the components (including soluble humin and humin precursors) in the extractable fraction in organic solvents (e.g., in acetone) since aqueous solution can cause problem in chromatography techniques.

NMR is a very useful characterisation tool for such a complex material. For further study, 2D-NMR should be employed for investigating the interaction of each functionality of humin and maybe of sodium species with humin.

As shown in chapter 3 , the presence of $\mathrm{Na}_{2} \mathrm{CO}_{3}$ not only improves the gasification rate tremendously, but also alters the composition of volatile products. Further investigation on the influence of the $\mathrm{Na}_{2} \mathrm{CO}_{3}$ loading is recommended. Micro-pyrolysis in $\mathrm{CO}_{2}$ or steam enriched gas can be a convenient solution for this investigation.

More detail of mass and carbon balance which distinguishes the contribution of gas, volatile products should be investigated.

With the current facility, the gasification was mainly performed using TGA which only allows maximum 2.5 vol.\% steam in the gas stream. And mass transfer is big issue in fix bed reactors for such fine powder materials. In practice, gasification is usually performed in a fluidised bed reactor at high pressure $(10-15$ bar). The performance (product selectivity, conversion rate) in fluidised bed at high pressure can be different from the results of this work. Conducting the gasification at higher pressures and in fluidisation bed are strongly recommended in order to establish a process design.

$\mathrm{Ce}-\mathrm{Zr}$ based catalyst with supported $\mathrm{Ni}$ shows great promise for steam removal of tars from humin. Doping $\mathrm{Zr}$ into Ce lattice can improve the oxygen capacity as well as redox properties of the mixed-oxide, and the catalyst. In this study, the low range $\mathrm{Ce} / \mathrm{Zr}(17 / 83)$ atomic ratio was chosen on the purpose of comparison with previous work. However, the catalyst system can be further optimised by varying $\mathrm{Ce} / \mathrm{Zr}$ ratio. Redox property of the supports is very importance to the performance of correspondent catalyst. Higher Ce content $(\mathrm{Ce} / \mathrm{Zr}=30 / 70-60 / 40)$ can be used since the mixed oxide with these compositions were reported to have highest redox properties in literature.

The oxygen mobility is an important factor which has strong influence on preventing coke formation during steam reforming of $\mathrm{m}$-cresol or acetic acid. Quantitative characterisation techniques for this property such as measuring the oxygen buffering capacity by alternating the oxidative gas stream at working temperatures $\left(\right.$ e.g., $\left.700{ }^{\circ} \mathrm{C}\right)$ can be very useful. 


\section{Scientific contributions}

\section{Publications}

T.M.C. Hoang, L. Lefferts, K. Seshan, Valorization of humin-based byproducts from biomass processing-a route to sustainable hydrogen, ChemSusChem, 6 (2013) 1651-1658.

T.M.C. Hoang, E.R.H. Van Eck, W.P. Bula, J.G.E. Gardeniers, L. Lefferts, K. Seshan, Humin based by products from bioprocessing as potential carbonaceous source for synthesis gas production, Green Chemistry, (submitted) (2014).

T.M.C. Hoang, N. Koteswara Rao, L. Lefferts, K. Seshan, Investigation of Ce-Zr oxide supported Ni catalysts in steam reforming of meta-cresol as model component for bio-derived tar, ChemSusChem, submitted (2014).

T.M.C. Hoang, B. Geerdink, J.M. Sturm, L. Lefferts, K. Seshan, Toward complete conversion of humin based by-product for sustainable hydrogen - Steam reforming of acetic acid a major component in the volatiles formed during gasification of humin, Applied Catalysis B: Environmental, Submitted (2014)

D.B. Thakur, R.M. Tiggelaar, T.M.C. Hoang, J.G.E. Gardeniers, L. Lefferts, K. Seshan, Ruthenium catalyst on carbon nanofiber support layers for use in silicon-based structured microreactors, Part I: Preparation and characterization, Applied Catalysis B-Environmental, 102 (2011) 232-242.

\section{Conference lecture}

T.M.C. Hoang, Y. Wang, I. van Zandvoort, P.C.A. Bruijnincx, B.M. Weckhuysen, H.J. Heeres, L. Lefferts, K. Seshan. Catalytic route for valorization of humin by-product, CatchBio progress meeting, Amsterdam, January 2014

T.M.C. Hoang, L. Lefferts, K. Seshan. Catalytic gasification - a potential route for valorisation of humin by-products formed during biomass processing, $11^{\text {th }}$ European Congress on Catalysis (EuropaCat), Lyon, France, September 2013

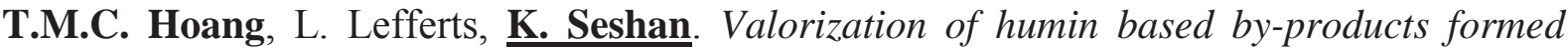
during biomass processing via gasification/synthesis gas route, $2^{\text {nd }}$ International Congress on Catalysis for Biorefineries, Dalian, China, September 2013 
T.M.C. Hoang, I. van Zandvoort, Y. Wang, P.C.A. Bruijnincx, B.M. Weckhuysen, H.J. Heeres, L. Lefferts, K. Seshan. Catalytic route for valorization of humin by-product, CatchBio progress meeting, Nunspeed, January 2013

T.M.C. Hoang, L. Lefferts, K. Seshan. Humin based byproducts formed during biomass processing - Potential carbonaceous source for syngas production, $13^{\text {th }}$ The Netherlands' Catalysis and Chemistry Conference (N3C), Noordwijkerhout, The Netherlands, March 2012

T.M.C. Hoang, T.Y.N. Dang, B.C.A. van der Veer, P. Bode, H. van den Berg, A. G. J. van der Ham. From natural gas to ethylene: a study on combining oxidative coupling of methane with steam reforming, $8^{\text {th }}$ European Congress of Chemical Engineering, September 2011, Berlin, Germany

I. van Zandvoort, Y. Wang, T.M.C. Hoang, H.J. Heeres, L. Lefferts, K. Seshan P.C.A. Bruijnincx, B.M. Weckhuysen. Catalytic route for valorization of humin by-product, CatchBio progress meeting, Nunspeed, January 2011

\section{Poster presentations}

T.M.C. Hoang, L. Lefferts, K. Seshan. Valorization of humin based by-products formed during biomass processing via synthesis gas production route, $23^{\text {rd }}$ Northern American Catalysis Society Meeting (NAM), Louisville, KY, USA, June 2013

T.M.C. Hoang, L. Lefferts, K. Seshan. Valorisation of Humin based by-products formed during biomass processing via steam reforming route for hydrogen production. $14^{\text {th }}$ Netherlands' Catalysis and Chemistry Conference, Noordwijkerhout, The Netherlands, March 2013

T.M.C. Hoang, L. Lefferts, K. Seshan. Catalytic routes for the valorisation of humin byproducts formed during biomass processing, $12^{\text {th }}$ Netherlands' Catalysis and Chemistry Conference, Noordwijkerhout, The Netherlands, March 2011 


\section{Acknowledgement}

First, I would like to show my great gratitude to Seshan, my promoter as well as daily supervisor. You not only had given me the chance to choose the research topic but also allowed me to conduct the study with a lot of freedom and independence. I am so grateful that you fully trust and support my work. That also gives me lot of confidence in myself.

I could not complete my lab work without the dedicated help from Bert. You are truly the binder of all CPM layers. I have learnt a lot of techniques, tips and tricks from you, not only those related to laboratorial skills but also those in normal life.

Leon, I really appreciate your constructive critics and input in my paper work. Those sometimes made me think, study further to give good explanations for which "were not trivial". As the result, those made the publication more details and completed.

To Kamila and Koteswara, thank you for being my paranymphs also for your willingness of sharing my concerns during these last years in CPM. I am glad that beside work related topics, I can chat with you about life.

To all other current also post-members of CPM, I really enjoy working and sharing some extra-activity with you such as the group trips or borrel. Although I had chance to acknowledge just some of you in my publications, you all contribute to my result today. The international atmosphere in CPM also bring me a lot of authentic knowledge about people, traditions and history of other countries which is valuable for me.

I also acknowledge to people from other organizations, who helped me with characterisation analysis: Enrst van Eck from Nijmegen University, Kathick from Leiden University for NMR analysis, Yehu Wang and Henk de Bovenkamp from Groningen University for humin synthesis. My special thanks go to Mark Smither for the beautiful SEM images that you took for me not only during my $\mathrm{PhD}$ research but also my master assignment and some of them were presented on the cover of this book.

I am gratitude to my colleagues at Hanoi University of Science and Technology (HUST) for supporting me in pursuing such long study and research abroad. I always wish that I can share my knowledge and experience to young students at HUST one day.

Besides the working and studying, during my seven years living in the Netherlands, I've come across and got known a lot of people and many of them supported me in a very different ways. I am so grateful to the support from Minh Duc Nguyen. I could not have impressed my promoters that much without your assistance with XRD or pulse laser deposition. You and 
Nhi were my family in Enschede during my first two year of master studying. Son, my colleague as well as an active member of the Vietnamese UT community, thank you for the pyrolysis, GC-MS analysis but also for hosting a lot of parties, meals in your apartment. I really enjoyed the time watching football there, although many times our favourite team lost. Lan Anh, thank you for taking care of my garden when I was on vacation. Trí Ngô, I am grateful for taking some inconvenient duty come from your neighbour (viz, me) such as watering my plants during the New Year holiday. I appreciate the hospitality provided by Hao's family and Duc. To Nhi, I enjoyed our studying and working together during master programme. I am happy that you appreciate our friendship. There are still a lot of nice people that I can not list all here but thank to you I can keep some traditions, improve some cooking skills and on top of it I feel like living in a Vietnamese "village" despite being ca. 9200 kilometers away from home.

The van der Veer family, Ans, Andre, Judith, Erik, you are my family in the Netherlands. Thank you for welcoming me to your warm family. Although there are some differences in culture, I learn and admire a lot of manner and customs in your family.

I am also grateful to the consideration and attention from my great family and close friends in Vietnam to me. I am happy that you will always follow my paces wherever I go.

The last gratitude words I would like to save to the nearest and dearest to my heart. Thank you for accompanying me along the $\mathrm{PhD}$ career, Bart. You are always there whenever I need help. My song named "PhD dissertation" today is featured by you. I always think love and care can be expressed in many forms. And we see it in each other. Manners or gestures are sometimes more powerful than words, aren't they? And the most important people, who always support me at any cost, scarify themselves for my development and happiness - are my Mother and sister. I couldn't imagine that I would stay away from home for such long time when I left home for the Netherlands in 2007. I first planned for 2 years of master studying, and then extended another 4 years more for $\mathrm{PhD}$ and now maybe I will be way for some infinite years. As the elder child in the family, I was not fulfilling my responsibility. But Mother ultimately supports all of my decisions. I know it is not easy for you and Phuong for dealing all of the problems I left behind. There is no word to express my thankfulness to you and Phuong. I don't know how to express my love externally but my love for you is always in my heart and soul. "Con cảm ơn Mẹ và em vì đã dành cho con những điều tốt đẹp nhất."

Enschede, June - 2014

Hoàng Thị Minh Châu 